$$
D \varepsilon(I D \mid 1304 \geqslant-5
$$

\title{
A COMPARATIVE EVALUATION OF \\ CONCEPTUAL MOdELS FOR THE SNAKE RIVER PLAIN AQUIFER \\ AT THE IDAHo CHEMICAL PROCESSING PLANT, INEL
}

A Thesis

Presented in Partial Fulfillment of the Requirements for the

Degree of Master of Science

with a

Major in Hydrology

, in the

College of Graduate Studies

University of Idaho

by .

Crispin J. Prahl

January 1992

\section{MASTER}




\title{
AUTHORIZATION TO SUBMIT THESIS
}

This thesis of Crispin J. Prahl for the Master of Science with a major in Hydrology, and entitled "A Comparative Evaluation of Conceptual Models for the Snake River Plain Aquifer at the Idaho Chemical Processing Plant, INEL", has been reviewed in final form as indicated by the signatures and dates given below. Permission is now granted to submit final copies to the College of Gfaduate Stugies for approval.

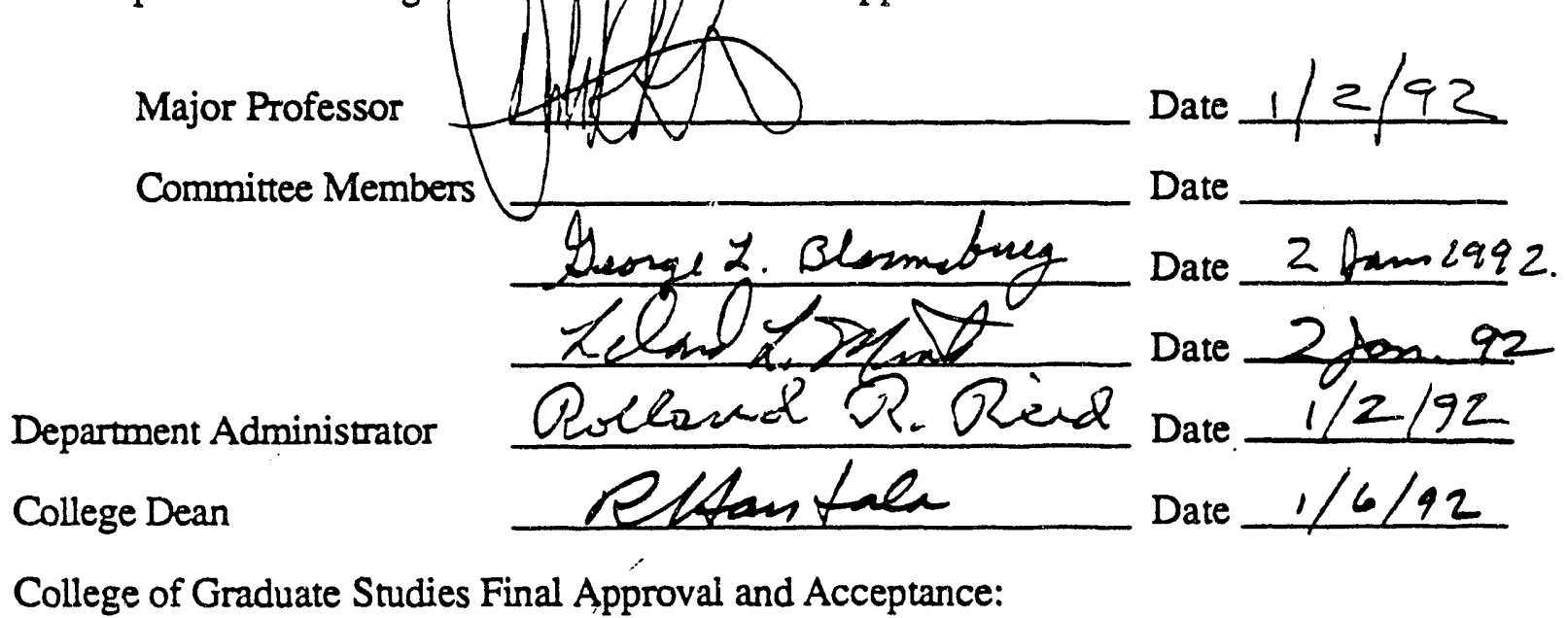

Date

\section{DISCLAIMER}

\begin{abstract}
This report was prepared as an account of work sponsored by an agency of the United States Government. Neither the United States Government nor any agency thereof, nor any of their employees, makes any warranty, express or implied, or assumes any legal liability or responsibility for the accuracy, completeness, or usefulness of any information, apparatus, product, or process disclosed, or represents that its use would not infringe privately owned rights. Reference herein to any specific commercial product, process, or service by trade name, trademark, manufacturer, or otherwise does not necessarily constitute or imply its endorsement, recommendation, or favoring by the United States Government or any agency thereof. The views and opinions of authors expressed herein do not necessarily state or reflect those of the United States Government or any agency thereof.
\end{abstract}


ABSTRACT

Geologic and hydrologic data collected by the United States Geological Survey (USGS) are used to evaluate the existing ground water monitoring well network completed in the upper portion of the Snake River Plain aquifer (SRPA) beneath the Idaho Chemical Processing Plant (ICPP). The ICPP is located at the south central end of the Idaho National Engineering Laboratory (INEL), about forty miles west of the city of Idaho Falls. Most monitoring wells at the ICPP are open over multiple water-producing zones, with uncased intervals commonly ranging from 100 to as much as 300 feet below the regional water table. The USGS data analyzed and compared in this study include: a) lithologic, geophysical, and stratigraphic information, including the conceptual geologic models developed by Jones (1961) and Anderson (1991), b) intrawell, ground water flow measurements (Tracejector tests) as described by Barraclough et al. (1967), and c) dedicated, submersible, sampling pump elevations as provided by Jensen (USGS, personal communication).

Qualitative evaluation of these data indicate that the upper portion of the SRPA is both heterogeneous and anisotropic at the scale of the ICPP monitoring well network. Meaningful spatial correlations of distinct hydrostratigraphic units (i.e., aquifers) are extremely difficult to establish between the majority of ICPP monitoring wells based on available hydrogeologic data. Basalt flow top units, which are believed to represent the most permeable pathways for horizontal ground water flow, do not appear to be laterally continuous based on caliper, natural-gamma, and lithologic logs. Limited spatial agreement exists between the aquifers defined by the hydrostratigraphic conceptual model of Jones (1961) and the basalt flow groups identified by the lithostratigraphic conceptual model of Anderson (1991).

Tracejector test results (after Barraclough et al., 1967a) indicate that the hydraulic interconnection and spatial configuration of water-producing zones is extremely complex 
within the upper portion of the SRPA. Intrawell ground water flow characteristics caused by hydraulic stresses at ICPP injection and disposal wells in the mid-1960's show no spatially recurring pattem at the scale of the ICPP area. Flow may be upwards, downwards, horizontal, or nonexistent depending on the specific depth and well location under consideration. The magnitude of intrawell ground water flow is also highly variable within the monitoring wells tested by Tracejector methods. The locations of waterproducing zones do not appear to be strictly controlled by the basalt flow group contacts as defined by Anderson (1991).

The majority of ICPP monitoring wells currently are equipped to sample ground water only from the upper lithostratigraphic intervals of the SRPA, primarily basalt flow groups E, EF, and F. Depth-specific hydrogeochemical sampling and analysis are necessary to determine if ground water quality varies significantly between the various lithostratigraphic units adjacent to individual sampling pumps.

The author concludes that the upper portion of the SRPA acts as a heterogeneous, anisotropic system at the scale of the ICPP monitoring well network. Additional data collection involving depth-specific, quantitative, hydrogeologic, hydraulic, and geochemical analyses are necessary to better understand the occurrence and movement of ground water both within individual monitoring wells and at the scale of the ICPP area as a whole. 


\section{ACKNOWLEDGEMENTS}

I would like to express my thanks and appreciation to Dr. Dale Ralston for his helpful advice and for obtaining the funding which made this project possible. Thanks also go to Dr. Roy Mink and Dr. George Bloomsburg for providing valuable comment during the development of this thesis and for reviewing the final manuscript. Appreciated funding for this project was made available by the Idaho Department of Health and Welfare INEL Oversight Program (contract number 5173). The author would also like to thank the staff of the U.S. Geological Survey, INEL Field Office, for their assistance in obtaining the data used in this thesis. Finally, my sincere gratitude is expressed to the entire staff of the Idaho Water Resources Research Institute, for the their support and good humor, and for allowing me to use the Institute facilities during the preparation of this report. 
TITLE

Page

AUTHORIZATION TO PROCEED WITH FINAL DRAFT ...........................i

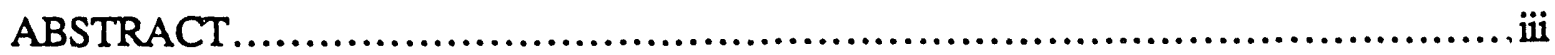

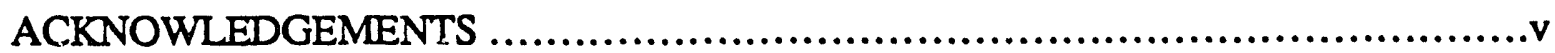

TABLE OF CONTENTS ........................................................ vi

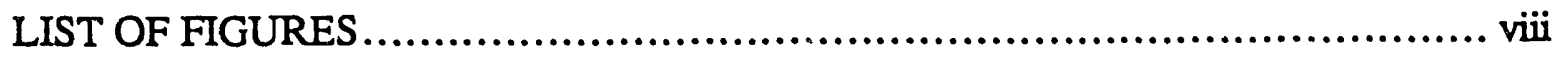

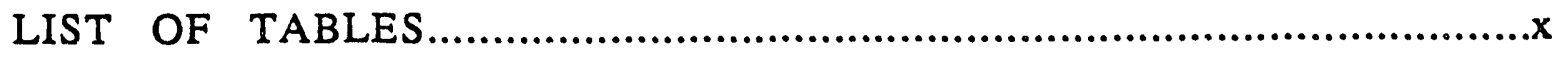

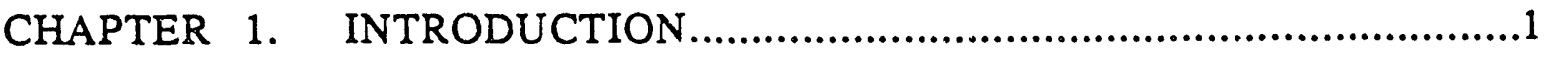

Statement of Problem...............................................................1

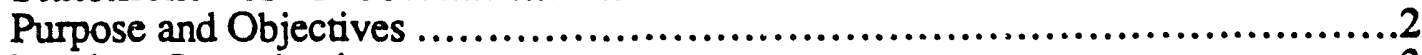

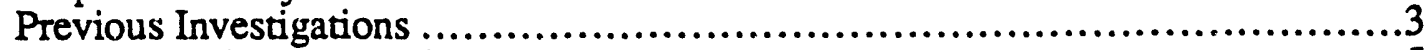

Definition of Stratigraphic Nomenclature .......................................5

CHAPTER 2. DESCRIPTION OF THE STUDY AREA..............................6

Introduction...................................................................6

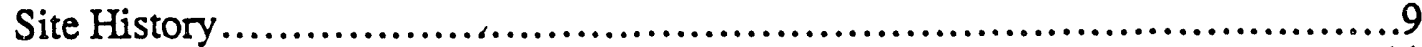

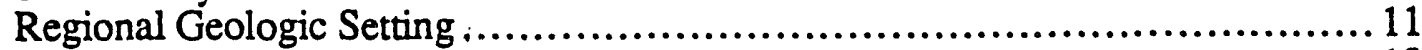

General Stratigraphy..................................................... 13

Tertiary Rocks................................................ 13

Quaternary Basalts............................................... 13

Surficial Deposits .................................................. 17

Structure .............................................................. 18

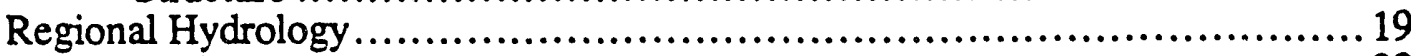

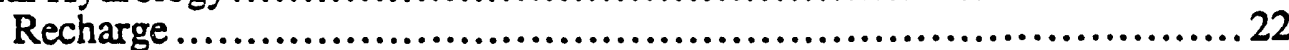

Ground Water Occurrence .............................................23

CHAPTER 3. DESCRIPTION OF ICPP WELL NETWORK..............................30

CHAPTER 4. PRESENTATION OF CONCEPTUAL MODELS........................... 36

Introduction................................................................. 36

Hydrostratigraphic Model of Jones (1961) .................................... 36

Geophysical Logging Methods Used..................................... 37

Natural-Gamma Logs ............................................. 37

Caliper Logs.................................................... 38

Methods of Correlation.................................................... 38

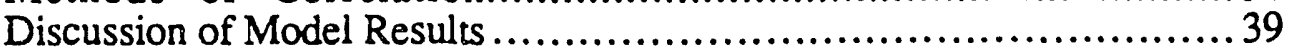

Lithostratigraphic Model of Anderson (1991) ................................... 48

Methods of Correlation...................................................4 48

Discussion of Model Results .......................................... 49 
CHAPTER 5. HYDROSTRATIGRAPHIC CORRELATION OF POST-

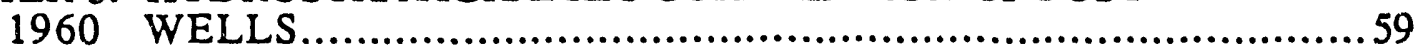

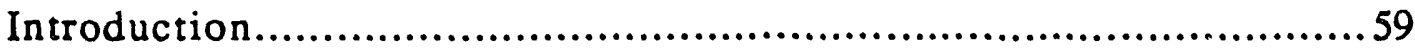

Correlation Between Post-1960 Wells ......................................6 61

Hydrostratigraphic Correlation Between Pre- and Post-1960 Wells...................64 64

Conclusions .............................................................66

CHAPTER 6. COMPARISON OF LITHOSTRATIGRAPHIC AND

HYDROSTRATIGRAPHIC INTERVALS .....................................6 68

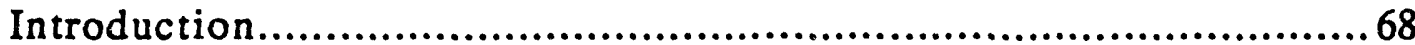

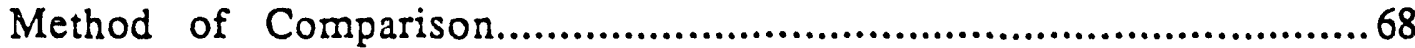

Discussion of Results ..............................................................71

Conclusions of Model Comparison......................................................75

CHAPTER 7. COMPARISON OF BOREHOLE FLOW MEASUREMENTS AND LITHOSTRATIGRAPHIC MODEL

RESULTS ................................................................ 77

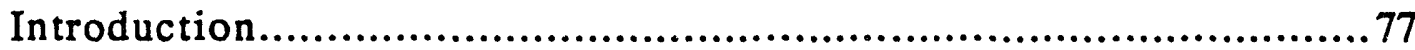

Description of Tracejector Tests..........................................................77

Method of Comparison.................................................................... 81

Analysis and Discussion of Results ........................................... 81

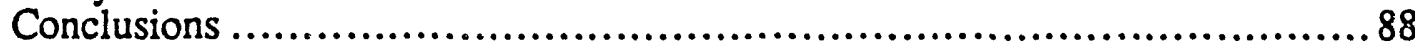

CHAPTER 8. GROUND WATER QUALITY SAMPLING INTERVALS.................99

Introduction........................................................... 90

Application of Submersible Sampling Pumps at the ICPP............................92

Discussion of Results ...................................................... 94

CHAPTER 9. SUMMARY, CONCLUSIONS, AND

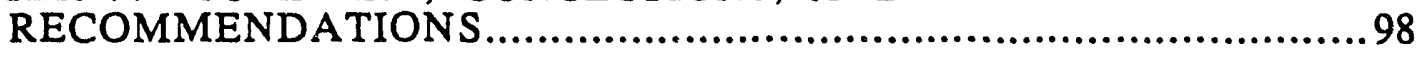

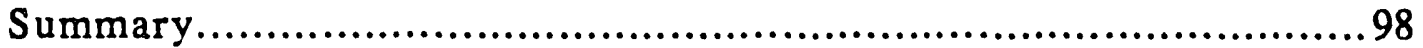

General Conclusions ............................................................ 99

Specific Conclusions .......................................................99

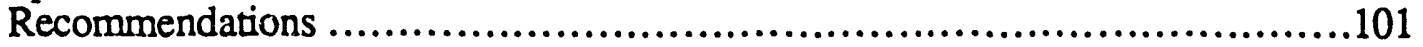

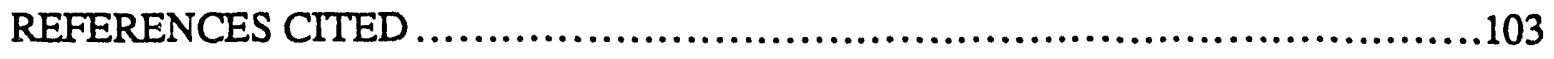

APPENDIX 1. Drillers' logs, geophysical lugs, and geologic interpretations for selected ICPP monitoring wells ..............................109

APPENDIX 2. Tracejector logs and geologic interpretations for selected ICPP monitoring wells. 


\section{LIST OF FIGURES}

Figure

1. Location of the Idaho Chemical Processing Plant and selected features at

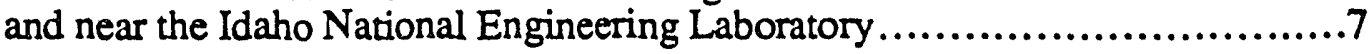

2. Location map of ground water monitoring wells and production wells penetrating the upper Snake River Plain aquifer in the vicinity of the ICPP......8

3. Relief map of Idaho showing the location of the INEL, Eastern Snake River Plain, and generalized ground water flow lines of the Snake River Plain aquifer.

4. Generalized schematic geologic section through the Eastern Snake River Plain in the vicinity of the INEL.

5. Generalized intraflow stratigraphy of Snake River Basalts showing structural controls on ground water movement.

6. Location and explanation of geologic section F-F through the Radioactive Waste Management Complex, the Idaho Chemical Processing Plant, and well NPR-TEST

7. Geologic section F-F through the Radioactive Waste Management

Complex, the Idaho Chemical Processing Plant, and well NPR-TEST showing the regional structural relationships within the Snake River Basalts and related sediments -- Continued

8. Geologic cross section from north to south through the ICPP area showing generalized stratigraphy, localized recharge sources, wells, and regional water table

9. Generalized map of the ICPP area showing the locations of wells, profiles, and cross sections used by Jones (1961)

10. Geologic cross section G-F from west to east through the ICPP area based on caliper and natural-gamma logs, showing conditions below the regional water table

11. Geologic cross section E-C from northwest to southeast through the ICPP area based on caliper and natural-gamma logs, showing conditions below the regional water table.

12. Geologic cross section H-J from southwest to northeast through the ICPP area based on caliper and natural-gamma logs, showing conditions below the regional water table.

13. 'Location and explanation of geologic section A-A' at the Idaho Chemical

Processing Plant and Test Reactors Area

14. Geologic section $\mathrm{A}-\mathrm{A}^{\prime}$ at the Idaho Chemical Processing Plant and Test

Reactors Area 
Figure

Page

15. Location and explanation of geologic section $B-B^{\prime}$ at the Idaho Chemical Processing Plant and Test Reactors Area ..................................52

16. Geologic section B-B' at the Idaho Chemical Processing Plant and Test Reactors Area.................................................................53

17. Location and explanation of geologic section C-C' at the Idaho Chemical Processing Plant and Test Reactors Area

18. Geologic section C-C' at the Idaho Chemical Processing Plant and Test Reactors Area.....................................................................55

19. Location and explanation of geologic section E-E' at the Idaho Chemical Processing Plant and Test Reactors Area .56

20. Geologic section E-E' at the Idaho Chemical Processing Plant and Test Reactors Area.

21. Location map of post-1960 monitoring wells used to test the hydrostratigraphic correlations methods of Jones (1961).

22. Interpretive hydrogeologic cross section $\mathrm{W}-\mathrm{W}$ through selected post-1960 monitoring wells at the ICPP based on natural-gamma and caliper logs, showing conditions below the regional water table.

23. North-south trending geologic cross section $X-X$ through the ICPP area comparing the geologic interpretations of Jones (1961) and Anderson (1991).

24. Ranking distribution for spatial correlations between aquifer intervals identified by Jones (1961) and basalt flow contacts identified by Anderson (1991)

25. Map of the ICPP area showing the location of monitoring wells surveyed by the USGS in 1965 using the Tracejector probe

26. Graphs of six wells at the ICPP area showing lithology, directions of flow, hole diameter, and velocity of flow at the time of Tracejector logging in 1965 .

27. Cross section $Y-Y^{\prime}$ through the ICPP area showing Tracejector results (after Barraclough et al., 1967a) and lithostratigraphic interpretations of Anderson (1991).

28. Cross section $\mathrm{Z}^{\prime} \mathrm{Z}^{\prime}$ through the ICPP area showing Tracejector results (after Barraclough et al., 1967a) and lithostratigraphic interpretations of Anderson (1991).

29. Cumulative spatial distribution of dedicated sampling pumps relative to the lithostratigraphic units identified by Anderson (1991) within monitoring wells at the ICPP. 


\section{LIST OF TABLES}

Table

Page

1. Barometric efficiencies of selected monitoring wells at the ICPP area ...........26

2. Changes in hydraulic conductivity of geologic formations with depth in test

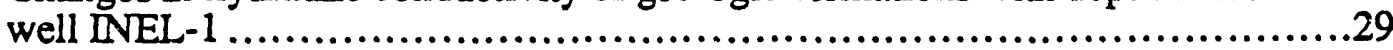

3. Completion information for wells penetrating the upper portion of the Snake River Plain aquifer system in the vicinity of the ICPP .

4. Types and quantities of geophysical logs available for wells in the vicinity of the ICPP

5. Depth, altitude, and thickness of aquifers " $A$ " through " $E$ " in the ICPP area as reported by Jones (1961).

6. Approximate depth, altitude, and thickness of aquifers " $A$ " through " $D$ " present in seven post-1961 monitoring wells at the ICPP based on the subsurface correlation methods of Jones (1961).

7. Comparative spatial relationships between hydrostratigraphic intervals (aquifers) and lithostratigraphic intervals (basalt flow units) for six selected monitoring wells penetrating the upper portion of the Snake River Plain aquifer at the ICPP.

8. Comparative summary of intrawell flow directions (after Barraclough et al., 1967a) and lithostratigraphic intervals (after Anderson, 1991) for seven ICPP monitoring wells surveyed with the Tracejector probe in 1965

9. Summary of dedicated sampling pump settings and adjacent geologic intervals for monitoring wells in the vicinity of the ICPP. 


\section{CHAPTER 1}

\section{INTRODUCTION}

\section{Statement of Problem}

The hydrogeology of the Snake River Plain aquifer in the vicinity of the Idaho Chemical Processing Plant (ICPP) at the Idaho National Engineering Laboratory (INEL) has been under investigation by the United States Geological Survey (USGS) since site development began by the Atomic Energy Commission (AEC) in the late 1940's. Despite these efforts, the lateral and vertical hydraulic continuity of the individual water-bearing zones within the now contaminated aquifer system are still poorly understood. This is due in part to the deficiency of confirmational, depth-specific hydrologic and hydrochemical testing data as well as the complexly heterogeneous nature of the interbedded basalts and sediments which comprise the upper portion of the regional saturated zone. A better understanding of the spatial configuration and hydraulic characteristics of the aquifer system is necessary in evaluating the vertical and horizontal extent of ground water contamination caused by decades of on-site waste water disposal.

The majority of ground water monitoring wells currently sampled at the ICPP are uncased over large vertical intervals of the upper portion of the Snake River Plain aquifer system. Open borehole intervals in older wells range from 100 to more than 300 feet (Bagby et al., 1984). These wells are completed through multiple, water-producing zones in basalt. The Snake River Basalt typically exhibits highly variable lithologic and hydrologic characteristics both internally and between flows. Vertical hydraulic gradients and resultant interaquifer ground water flow are known or suspected to exist in many ICPP monitoring wells (Robertson et al., 1974). These conditions present difficulties for obtaining representative, depth-specific ground water samples using the dedicated 
submersible sampling pumps which are currently installed in most of the ICPP monitoring wells. The spatial relationship between geologic intervals and the depths of the sampling pumps is necessary to develop meaningful ground water quality interpretations for the ICPP area.

\section{Purpose and Objectives}

The purpose of this study is to develop a better understanding of the monitoring network constructed in the upper portion of the Snake River Plain aquifer in the vicinity of the ICPP at the INEL. The general objectives are to qualitatively compare and evaluate two existing hydrostratigraphic and lithostratigraphic conceptual models describing the Snake River Plain aquifer at the ICPP and compare these results to Tracejector data and dedicated submersible sampling pump intervals within the existing ground water monitoring well network. This study is also designed to test the hypothesis that basalt flow group contacts

are correlatable with: a) zones of significant borehole enlargement observed on caliper logs and b) zones of previously measured, interaquifer ground water flow within selected ICPP boreholes. This work will be used as a baseline study for ongoing straddle-packer studies and depth-specific ground water sampling experiments at the ICPP by the universities within Idaho and the Idaho Department of Health and Welfare INEL Oversight Program.

The specific project objectives are to:

1. Review pertinent hydrologic literature and present a discussion of the existing USGS monitoring well network, previous hydrogeologic investigations, and existing conceptual geologic models relating to the regional aquifer system beneath the ICPP, placing particular emphasis on the ccnceptual models of Jones (1961) and Anderson (1991),

2. Describe the general hydrogeology of the Snake River Plain aquifer in the vicinity of the ICPP, 
3. Utilize the the subsurface corrslation methods of Jones (1961) to analyze the spatial distribution of inferred hydrostratigraphic units for monitoring wells completed in the upper portion of the Snake River Plain aquifer since 1960,

4. Compare and evaluate the hydrostratigraphic interpretations based on the conceptual model of Jones (1961) to the lithostratigraphic interpretations of Anderson (1991) below the regional water table for selected ICPP monitoring wells,

5. Describe the relationship between the distinct basalt flow group contacts defined by Anderson (i991) and intervals of in-hole ground water flow measured by Tracejector testing (Barraclough et al., 1967a) in seven ICPP monitoring wells,

6. Determine spatial relationship between the lithostratigraphic units interpreted by Inderson (1991) and the depth of dedicated, submersible, ground water sampling pumps presently used by the USGS in ICPP monitoring wells. This comparison is used to define qualitatively which lithostratigraphic units are most likely to be contributing to the ground water samples presently collected during routine monitoring in these wells.

\section{Previous Investigations}

The USGS has been actively involved in the investigation of hydrogeologic conditions at the ICPP and surrounding facilities beginning in 1949 (Jones and Voegeli, 1950). Since that time, the USGS has published a series of detailed summary reports describing site activities and ground water related studies conducted at the INEL (Nace et al., 1951, 1956; Peckham., 1959; Olmsted, 1962; Morris et al., 1963, 1964, 1965; Barraclough et al., 1967a, 1967b; Robertson et al., 1974; Barraclough et al., 1976b, 1981; Lewis et al., 1984; Pittman et al., 1988). These reports emphasize the geochemical effects of long-term liquid-waste disposal upon the upper portion of the regional ground water system. 
Jones (1961) presents a hydrostratigraphic correlation of basalt "aquifers" and associated sediments between 15 monitoring wells completed at the ICPP prior to 1960 . Five principal water-bearing zones are identified and correlated in the upper two hundred feet of the Snake River Plain aquifer using lithologic and selected geophysical logs. Correlations are based largely on the caliper logs, which show "a high degree of similitude for the same lava-top materials from well to well" (Jones, 1961, p. 29). Plans to hydraulically isolate, verify, and quantify these "aquifers" were abandoned by the USGS in mid-60's apparently due to equipment limitations and exceedingly high formation transmissivities (Morris et al., 1963, 1964). The methods of interpretation used by Jones (1961) are discussed, evaluated, and qualitatively tested in this report using subsurface data derived from selected monitoring wells drilled after 1960.

During the period of 1963 through 1970, the USGS studied small-scale vertical hydraulic head differences in the vicinity of the ICPP by measuring vertical ground water flow patterns within selected wellbores (Morris et al., 1964, 1965; Barraclough et al., 1967a, 1967b; Robertson et al., 1974). A complex pattern of vertical ground water movement is displayed by these "Tracejector" tests (Robertson et al., 1974); at any particular depth flow may be horizontal, upwards, downwards or stagnant depending on the borehole under consideration.

Anderson (1991) describes a complex sequence of basalt flows and sedimentary interbeds underlying the ICPP and Test Reactors Area (TRA). As many as eight distinct basalt flow groups are identified in the uppermost 220 to 270 feet of the Snake River Plain aquifer system. The areal extent and vertical delineation of basalt flow groups beneath the ICPP are demonstrated using geophysical logs, lithologic logs, and by correlation of offsite core sample data. Natural-gamma logs are used as the primary tool for establishing lithostratigraphic correlations between ICPP monitoring wells. Stratigraphic control is also provided by potassium-argon ages, paleomagnetic properties, and petrographic characteristics of basalt flows sampled from nearby well cores. 


\section{Definition of Stratigraphic Nomenclature}

A hydrostratigraphic unit is defined as a formation, part of a formation, or group of formations in which there are similar hydrologic characteristics that allow for classification of identifiable aquifers and associated confining layers (Domenico and Schwartz, 1990). The intrinsic hydrologic characteristics of hydraulic conductivity and porosity represent the fundamental attributes of all earth materials which are used for identifying and describing hydrostratigraphic units (Seaber, 1988). Hydrostratigraphic units are defined by the number, size, shape, arrangement, and interconnection of their interstices, and are recognized on the basis of the nature, extent, and magnitude of the interstices in any body of consolidated or unconsolidated geologic material (Seaber, 1986). The term hydrostratigraphic unit can only be loosely used in this report due to the deficiency of depth-specific hydrologic measurements. However, the term is considered to be descriptive of the laterally continuous "flow-top aquifers" and "intermediate dense basalt" layers as mapped and described by Jones (1961). The term hydrostratigraphic unit was initially introduced to the hydrologic literature by Maxey (1964), which explains why hydrostratigraphic units were not formally referenced in Jones's description of the upper portion of the Snake River Plain aquifer beneath the ICPP.

A lithostratigraphic unit is defined as a rock unit exhibiting similar and mappable lithologic character, stratigraphic association, and chemical properties (NACSN, 1983). A lithostratigraphis unit must posses some degree of lithologic homogeneity or distinctive lithologic features and is generally comprised of stratiform rocks (Seaber, 1988). Igneous rocks, including basalts, are more specifically referred to as lithodemic units, which are recognized by bounding unconformities as well as lithic character. In this thesis, however, the basalt flow groups and related sedimentary interbeds are loosely described as lithostratigraphic units because they are largely stratiform in nature and have been differentiated based on distinctive lithologic and chemical properties (Anderson, 1991). 


\title{
CHAPTER 2
}

\section{DESCRIPTION OF STUDY AREA}

\author{
Introductioil
}

The Idaho Chemical Processing Plant (ICPP) is located in eastern Idaho at the south central end of the Idaho National Engineering Laboratory, about forty miles west of the city of Idaho Falls (Figure 1). The ICPP, which is used for reprocessing used nuclear fuel elements, is approximately eight miles north of the INEL's southern boundary and occupies an area of 0.15 square miles. The ground water monitoring well network under consideration in this study occupies a total area of about 1.5 square miles (Figure 2).

The INEL is situated in an area of relatively low topographic relief and is typified by a sagebrush landscape. The land surface elevation ranges from 6605 feet above sea level at East Butte to an altitude of about 4775 feet in the north central portion of the INEL (Walker, 1964). The ICPP area is located at an elevation of approximately 4920 feet above sea level. The Bitterroot, Lemhi and Lost River Ranges rise from the margin of the Snake River Plain to the north and northwest of the site. South of the INEL, in striking contrast to the low relief of the central plain, three volcanic buttes (Big Southern, Middle, and East) rise abruptly from the plain.

The Little Lost River, Birch Creek, and Big Lost River drain the mountains to the north and northwest and terminate on or near the INEL. This area of closed drainage is cailed the Pioneer Basin (Nace et al., 1956, p. 5). The ICPP is situated on the broad flood plain of the Big Lost River, whose main channel is located just to the north of the ICPP compound. Recharge effects from the Big Lost River are very pronounced in the Snake River Plain aquifer and in the perched ground water systems beneath the river itself (Robertson et al., 1974). 


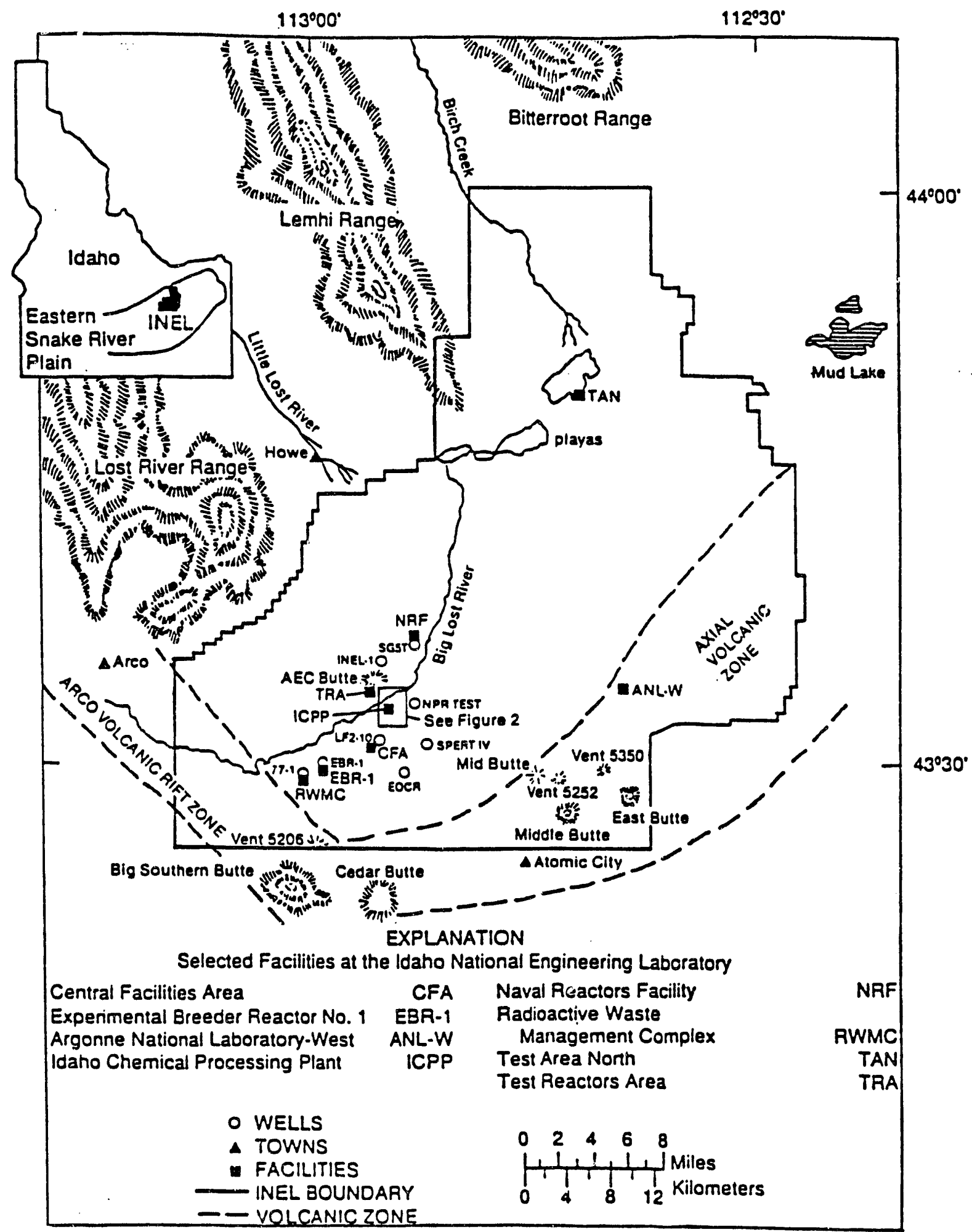

Figure 1. Location of the Idaho Chemical Processing Plant and selected features at and near the Idaho National Engineering Laboratory (after Anderson, 1991). 


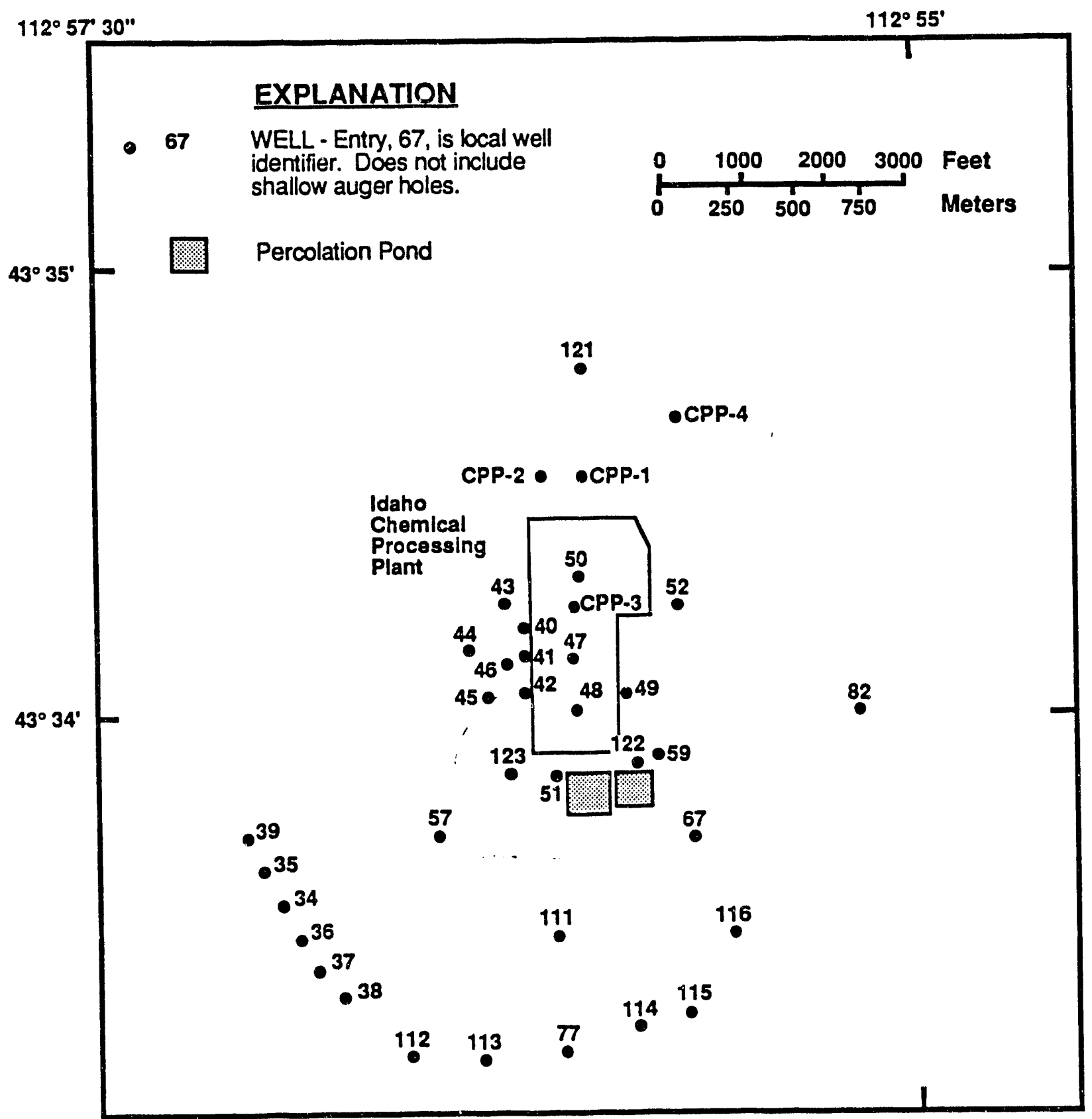

Figure 2. Location map of ground water monitoring wells and production wells penetrating the upper portion of the Snake River Plain aquifer in the vicinity of the ICPP (after Anderson, 1991). 
The average annual precipitation at the ICPP is 9.07 inches with yearly totals ranging from 4.50 to 14.40 inches (U.S. DOE, 1990b). The average annual air temperature is $42^{\circ} \mathrm{F}$ with temperatures ranging from $-40^{\circ} \mathrm{F}$ to $101^{\circ} \mathrm{F}$ (Robertson et al., 1974).

\section{Site History}

The ICPP was constructed from 1950 to 1953 by the Atomic Energy Commission for "developing and researching peacetime uses of atomic energy" (Robertson et al., 1974, p. 1). Currently, used nuclear-fuel elements are dissolved at the plant, and unused fissionable material is extracted for reuse in new fuel elements.

Radioactive and chemical wastes generated during fuel reprocessing have been discharged to the subsurface environment at the ICPP through a disposal well and/or unlined percolation ponds for more than four decades. A 598-foot deep, 24-inch diameter drilled well, extending approximately 140 feet below the regional water table, was completed at the ICPP in 1951 for the sole purpose of disposal of liquid wastes (see Figure 2). This injection well, commonly known as CPP-3 or CPP-DISP, was originally completed with a 16-inch diameter steel casing and gravel pack (U.S. DOE, 1990b). The casing was originally perforated from 412-452 feet and from 490-593 feet below land surface adjacent to intervals of fractured basalt.

Disposal of low-level radioactive and chemical wastes to the upper portion of the Snake River Plain aquifer began in early 1952. The volume and chemistry of wastes discharged to the aquifer have varied considerably since that time (Lewis et al., 1985). Preliminary hydrogeochemical analysis by Jones (1961) suggests that most of the waste water was initially introduced to a relatively permeable interval of the aquifer between the depths of approximately 475 and 535 feet. However, the history of effective injection intervals has varied considerably over time due to intermittent and often undetected 
collapses of the injection well casing during its use. The first collapse occurred in 1967 or early 1968 at a depth of 226 feet during a period of heavy usage (Robertson et al., 1974). This casing failure resulted in the temporary discharge of waste water to a perched aquifer system above the first underlying, locally extensive sedimentary interbed located at a depth of 370 feet. The injection well was redrilled and relined early in 1971 to correct this problem. The well collapsed again sometime between 1971 and 1982 and was reopened to the water table in late 1982 (U.S. DOE, 1990b). At this time the injection well was refitted with a high-density polyethylene liner which was perforated with 1-inch diameter holes from a depth of 450 feet to the bottom of the well.

Routine use of the injection well was discontinued on February 7, 1984. Since 1984 , most of aqueous wastes generated by the ICPP, which consist primarily of cooling water and steam condensate, have been discharged to a pair of unlined infiltration ponds located 2400 feet south of the injection well (see Figure 2). This change in disposal method was brought about by increasing concerns over the long-term ground water quality impacts associated with continued subsurface injection. Infiltration ponds were built to allow for increased attenuation of both low-level radioactive and industrial waste materials in the shallow unsaturated zone, thereby reducing a potential source of contamination to the regional ground water system. The disposal well received only occasional "emergency" use until March of 1986 and was grouted and sealed in 1989 (Fenix and Scisson, 1989; U.S. DOE, 1990b). Present ICPP processing wastes are discharged to the two unlined percolation ponds.

The DOE estimates that a total of 21,302 curies (approximately $94.5 \%$ tritium, a hydrogen isotope with a 12.3 year half-life) were released to the injection well between 1952 and 1986 (U.S. DOE, 1990b). The reader is referred to Robertson et al. (1974) for a detailed discussion of the volume and chemical and radiological characteristics of wastes injected to CPP-3 during the period of 1952 through 1970. The monthly and yearly 
quantities of waste water discharged to the ICPP disposal well during 1962-84 and percolation ponds during 1984-85 are discussed by Pittman et al. (1988).

The migration of the ICPP's radioactive and chemical wastes to and within the upper portion of the Snake River Plain aquifer has been studied by the USGS since site use began by the AEC in 1952 (Peckham, 1959). Thirty-two ground water monitoring wells have been completed within the upper portion of the regional aquifer system in the vicinity of the ICPP since 1953 (see Figure 2). These wells have been installed to evaluate the geologic, geohydrologic, and geochemical characteristics of the aquifer as well as the stratigraphy of the 460-foot thick unsaturated zone (Jones and Jones, 1952; Jones, 1961; Keys, 1963; Chase et al., 1964; Walker, 1960, 1964; Bagby et al., 1984; Bartholomay, 1990; U.S. DOE, 1990a; Anderson, 1991). The USGS has been responsible for the location, design, construction, logging and long-term monitoring of these monitoring wells.

\section{Regional Geologic Setting}

The INEL is located on the west-central part of the eastern Snake River Plain, a large, northeast-trending graben or downwarped structural basin roughly 12,000 square miles in area (see Figure 3). The basin has been filled to its current level with approximately 2,000 to 10,000 feet of relatively thin, Quaternary and Tertiary age, basaltic lava flows, cinders and ash deposits in the upper section, and rhyolitic tuff and ash deposits in the lower section (Doherty et al., 1979; Whitehead, 1986). Rhyolitic domes, such as Big Southem, Middle, and East Buttes, intrude the basaltic and rhyolitic basin-fill rocks and are elevated by as much as 2000 feet above the surface of the plain (Robertson et al., 1974). Interbedded deposits of clay, silt, sand and gravel of fluvial, lacustrine, and eolian origin are common in the upper 2000 feet of basaltic rocks which underlie the INEL. A thin veneer of recent alluvium, deposited principally by the 


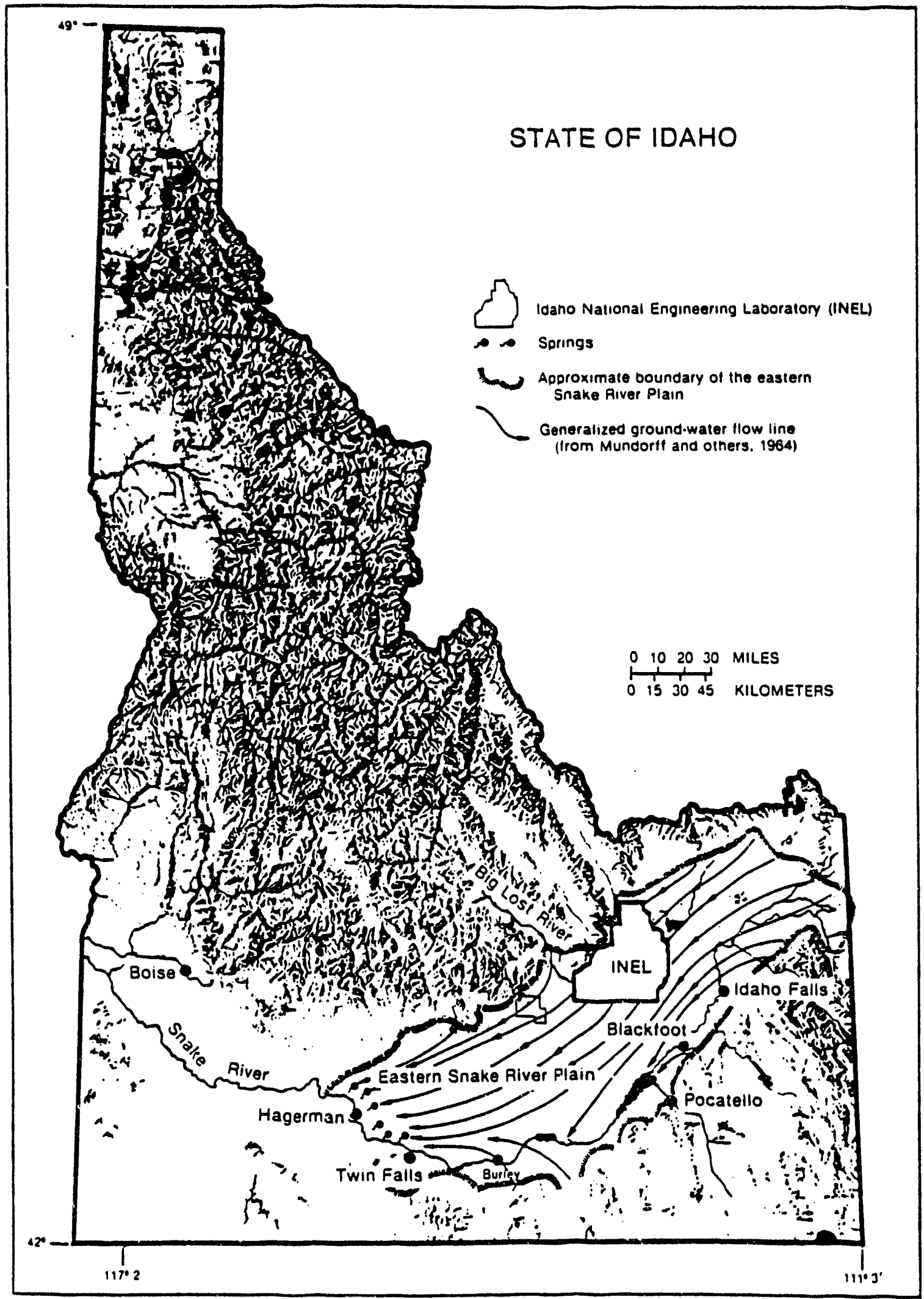

Figure 3. Relief map of Idaho showing the location of the INEL, Eastern Snake River Plain, and generalized ground water flow lines of the Snake River Plain aquifer (from Barraclough et al., 1981). 
surrounding surface streams, caps the basalt sequence in many areas of the INEL. A comprehensive discussion of the geological evolution of the Snake River Plain is given by Robertson et al. (1974), Hackett et al., (1986) and Lindholm and Vaccaro (1988). The geologic units which comprise the eastern Snake River Plain are described below.

\section{General Stratigraphy}

\section{Tertiary Rocks}

Rhyolitic lavas, ash and welded tuffs form the effective basement of the eastem Snake River plain (Figure 4). These volcanic units were extruded and deposited on the ancestral erosional surface of folded Paleozoic-age sedimentary rocks, probably during Pliocene time (Walker, 1964). Tertiary age rocks outcrop primarily in the mountainous terrain at the edges of the plain and within the remnants of rhyolitic volcanoes which now form the prominent buttes at the southern boundary of the INEL. These silicic rocks are believed to be a younger lithostratigraphic equivalent of the Idavada Volcanics which form the effective base of the western Snake River plain (Robertson et al., 1974; Hackett et al., 1986). Rhyolitic rocks seldom contribute to the ground water resources of the eastern plain due to their comparatively low hydraulic conductivity and excessive depth of burial (Luttrell, 1982).

\section{Quaternary Basalts}

The Snake River Group overlies the rhyolitic sequence and is the dominant rock unit found at the surface over most of the eastern plain. Flows within the group consist mainly of medium- to dark-gray beds of vesicular to dense olivine basalt. Snake River Basalt flows in the eastern plain typically occur as layers of pahoehoe lava a few feet to a 


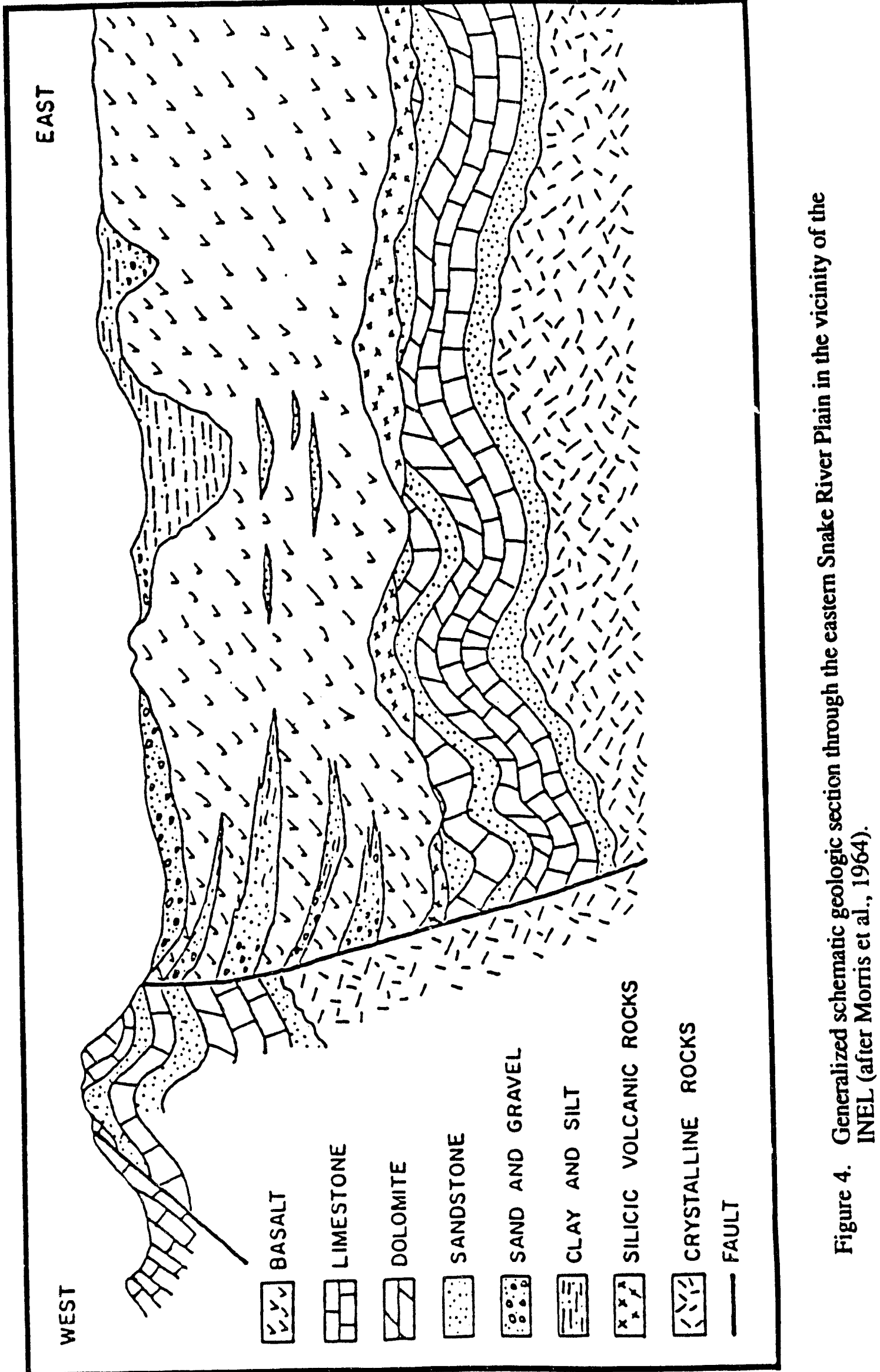


few tens of feet in thickness (Mundorff et al., 1964), but may reach several hundred feet where they fill ancestral canyons (King, 1977). The average thickness of basalt flows across the INEL is on the order of 10 feet (Nace et al., 1956).

Considerable variation in texture may be observed within individual basalt flow units, as shown in Figure 5. The three-layered, intraflow structures shown in Figure 5 result primarily from the rapid cooling of the lower and upper flow contacts and more gradual cooling of the flow interior (Nace et al., 1956; Kuntz et al., 1980). Flow tops typically consist of fine-grained, vesicular, variably brecciated, clinkery basalt. Vesicles and fractures within flow tops are commonly filled with fine-grained sediments where individual flows were exposed at the earth's surface after emplacement. The bases of most basalt flows are glassy to fine-grained, minutely vesicular to scoriaceous, and in many places exhibit a platey structure. The middle portions of individual basalt flow units are typically coarser grained and vertically jointed with comparatively few vesicles.

Vesicularity generally decreases with depth within the flow interiors. The massive interiors of outcropping basalt flows at the INEL generally contain columnar joints. These joints Sirm due to material shrinkage during cooling of the fresh basalt flow. Columns generally form perpendicular to the cooling surface.

Basalt flow groups are commonly separated by sedimentary interbeds of variable thickness and composition (Anderson, 1991). Interbeds are the result of sediment accumulation on the ancestral land surface during extended periods of volcanic quiescence. Periods of volcanic inactivity in the eastem Plain ranged from thousands to hundreds of thousands of years during the Quaternary period (Kuntz et al., 1980). Sedimentary layers consist of poorly to well sorted clay, silt, sand, and gravel of fluvial, lacustrine or eolian origin. Interbed units are locally up to 50 feet thick and vary in their lateral continuity depending on the ancestral topography and depositional environment. Volcanic cinders, ash and basaltic rubble are commonly intercalated with the interbed sediments (Jones, 1961). 


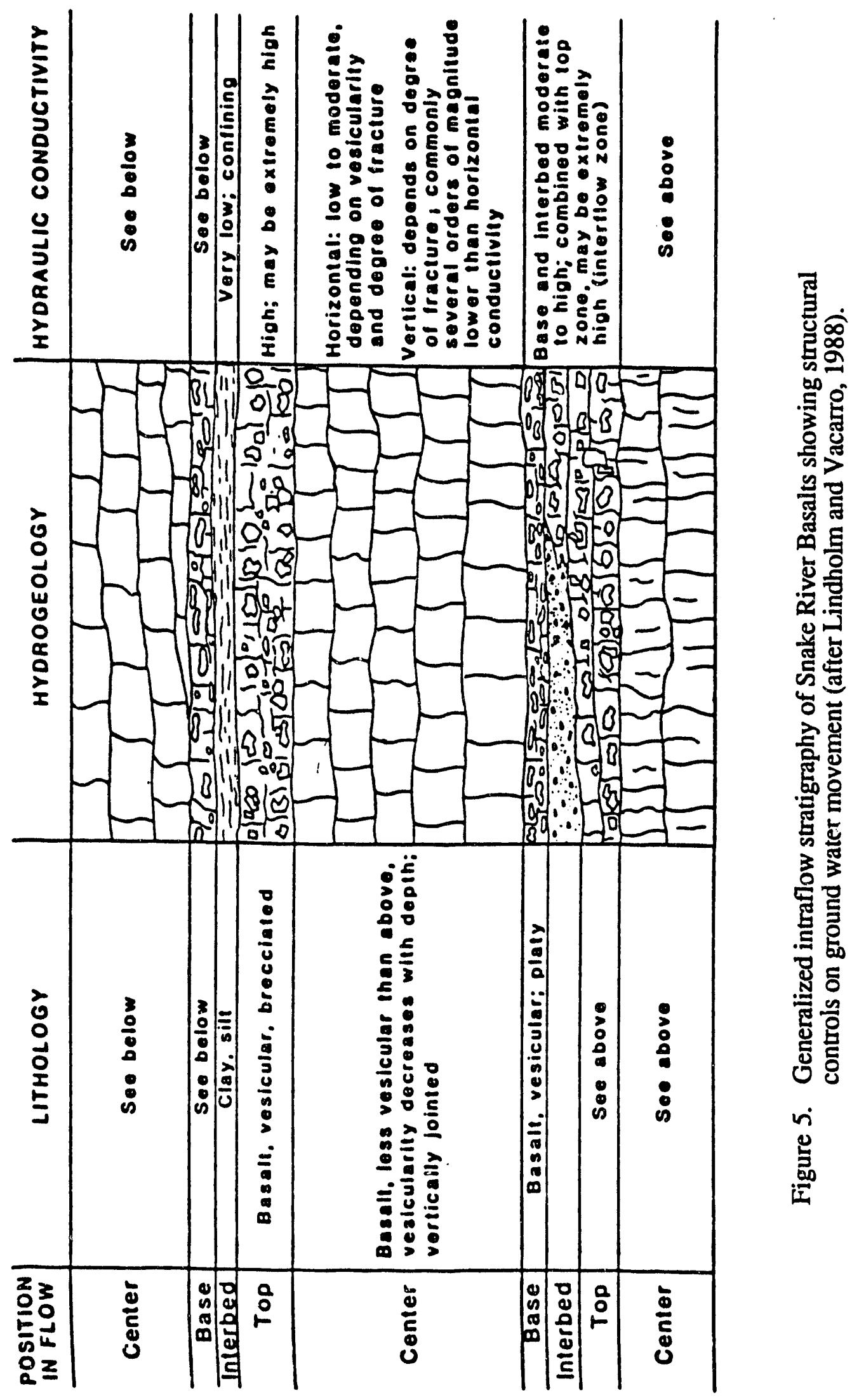


Basalts of the Snake River Group at the INEL appear to have been extruded primarily from a series of northwesterly trending volcanic vents, most of which were aligned along the Arco Volcanic Rift zone (see Figure 1). The rift zones is generally oriented perpendicular to the long axis of the plain (Kuntz and Dalrymple, 1979). The northeast treinding Axial Volcanic zone also contributed significant thicknesses of basaltic lava to the area during late Pleistocene magmatism (Anderson, 1991). The USGS and others have identified at least 23 different source vents which have inundated the southern INEL, area with basaltic lava flows, ash, and cinders over the past 640,000 years (Anderson, 1991).

\section{Surficial Deposits}

The surficial deposits, which cover most of the INEL, were emplaced by both wind and water. These sediments include alluvial silt, sand, and gravel, lacustrine and playa sand and silt, fine windblown sand and silt, and slope wash deposits (Nace et al., 1956). The sedimer:s of aqueous origin are found in alluvial fans, deltas, channel fillings, beach deposits and bar deposits. The coarser water-laid deposits range from poorly to well sorted. The eolian materials are found in localized sand dunes and thin mantles of wind blown loess (W:lker, 1964).

Much of the surficial alluvium was deposited during the waning stages of the Late Wisconsin glaciation (Jones, 196!; Walker, 1964). Rapid melting of nearby alpine glaciers combined with high seasonal precipitation allowed for the fluvial transport of gravel- to cobble-sized sediments across northern portions of the INEL.

A thin package of alluvial flood-plain sediments, deposited by the Big Lost River, mantles the basalt in the vicinity of the ICPP. The upper 35 to 40 feet of highly permeable alluvial sediments consist of well-graded gravels, gravelly sands, and sands with few finegrained materials (Hull, 1987). The larger, well-rounded clastic fragments are composed 
primarily of quartzite, limestone, dolomite and fine-grained igneous rocks (Bartholomay et al., 1989). This coarse-grained upper layer is underlain by 0 to 10 feet of clayey sands and sand-clay mixtures which directly overlie the Snake River Basalt. This clayey layer is known to create localized zones of perched ground water beneath the waste discharge areas at the ICPP, which have historically included leaking underground pipes, septic systems, shallow seepage pits, and the existing percolation ponds (Morris et al., 1964 and 1965; Robertson et al., 1974; Hull, 1987).

A detailed summary of the material properties for the shallow sediments at the ICPP is beyond the intent and scope of this report. Hull (1987) describes sediment properties including grain-size distribution, mineralogy, cation exchange capacity, and sorption coefficients. The vertical movement of water through the unsaturated zone at the ICPP is also discussed in Hull's report.

\section{Structure}

Basalts of the Snake River Group exhibit relatively few large structural features in comparison to the complexity and variety of large-scale geologic structures observed in the mountainous areas bordering the eastern Snake River plain. Deep-seated structures in the Tertiary-age rhyolitic basement are masked everywhere by the overlying sequence of Quatemary-age basalt flows. The basalt flows themselves typically exhibit a variety of small-scale internal structures, including layering, fractures, open fissures and primary voids. However, the areal distribution of these small-scale features within the basalt aquifer beneath the ICPP is not currently characterized in detail.

Stratigraphic interpretations by Anderson (1991) at the ICPP-TRA suggest that localized deformation of the Snake River Group resulted from simultaneous subsidence and uplift distributed across tens to hundreds of square miles of the eastern plain. Basalts and related sediments which comprise the regional aquifer system at the INEL have been 
affected by three different periods of structural deformation (Anderson, 1991).

Stratigraphic relationships between the ICPP, TRA, and RWMC indicate that suructural and depositional relief of up to 400 feet exists in the shallow subsurface (see Figures 6 and 7) due to repeated episodes of regional subsidence, localized uplift, and multiple eruptions of basalt (Anderson, 1991). Vertical fracturing related to differential structural movements may cut many of the saturated basalt units at depth, although the existence of such buried features has not been confirmed by standard geologic mapping techniques (Anderson, 1991, p. 33).

\section{Regional Hydrology}

Nearly all of the eastem Snake River Plain is underlain by a vast ground water system, the Snake River Plain aquifer. This aquifer system is believed to contain greater than 1 billion acre-feet of water (Robertson et al., 1974). The principal directions of ground water flow in the aquifer are generally to the southwest (and west) (see Figure 4) at velocities of 5-20 feet prer day (Robertson et al., 1974). The transmissivity of the aquifer at the INEL is reported to range from 1.1 to $7.6 \times 10^{5}$ feet squared per day based on a total of 183 single-well pumping tests conducted at 94 wells (Ackerman, 1991). Total aquifer transmissivity is controlled by the number and thickness of highly permeable interflow zones which commonly exist between basalt flows (Lindholm and Vaccaro, 1988). A rough estimate of the mean hydraulic conductivity $\left(\mathrm{K}_{\mathrm{m}}\right)$ of the aquifer is obtained by dividing the transmissivity by the penetration of the well below the water table (Ackerman, 1991 , p. 30 ). $K_{m}$ values calculated by this method range from $8.6 \times 10^{-3}$ to $5.5 \times 10^{3}$ feet/day. However, the actual hydraulic conductivities of individual interflow zones which comprise the composite aquifer system are likely to be substantially higher than the mean values estimated from these pumping tests. 


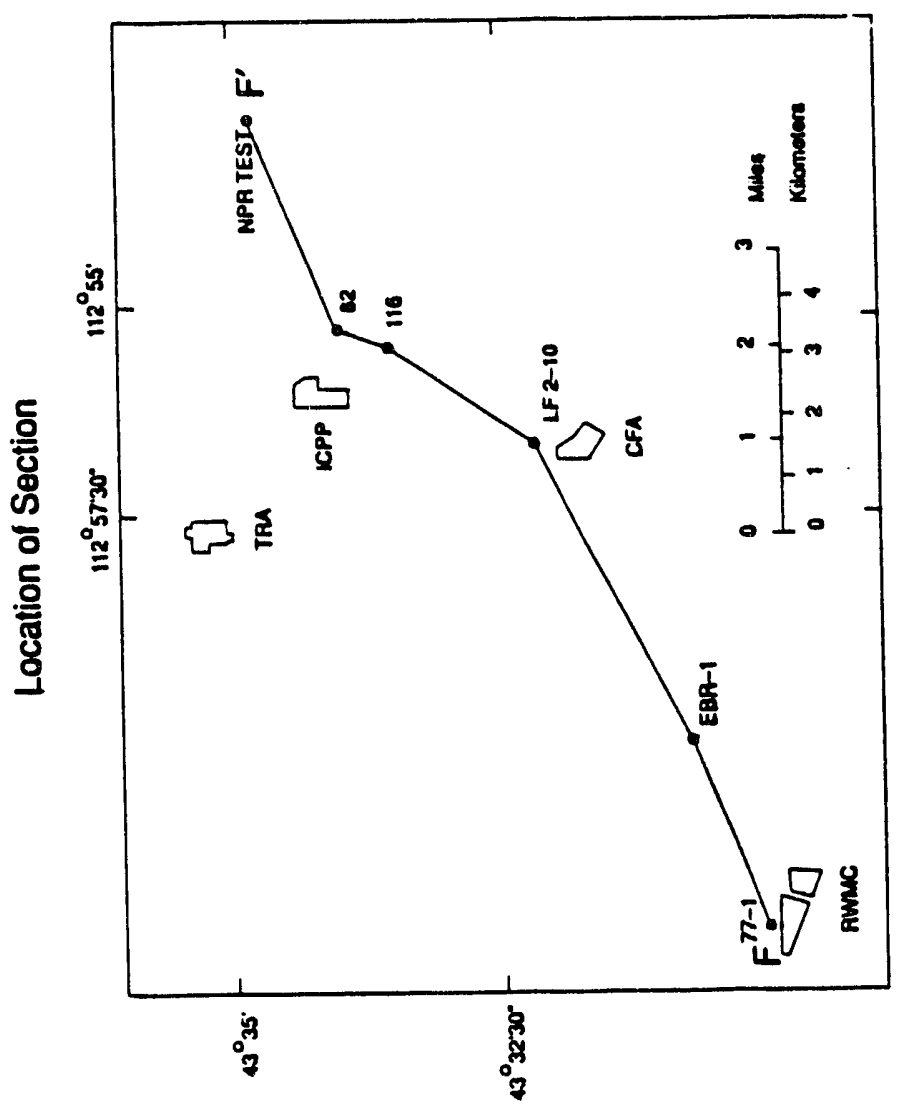

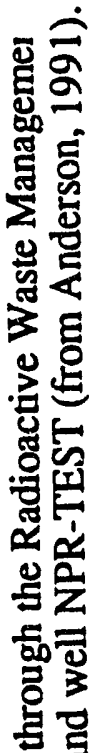

I.

I.

흠

웛. 옹

. ญू

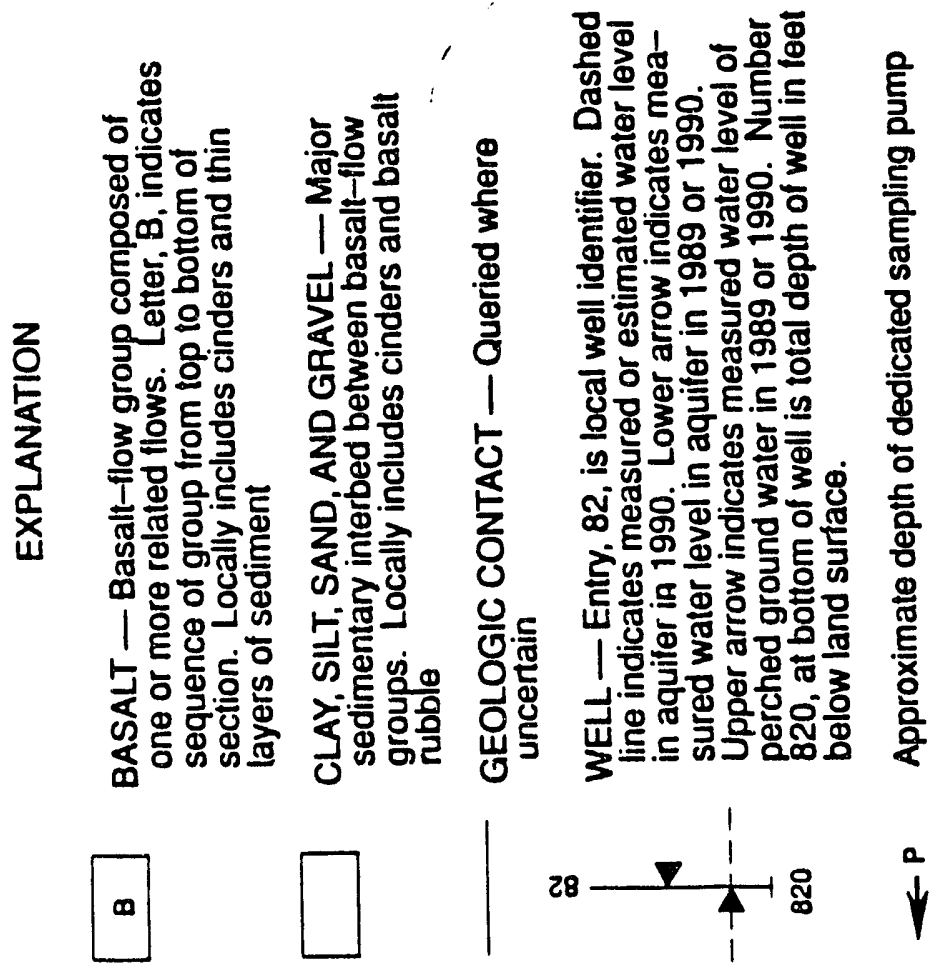

을

$\stackrel{a}{1}$ 


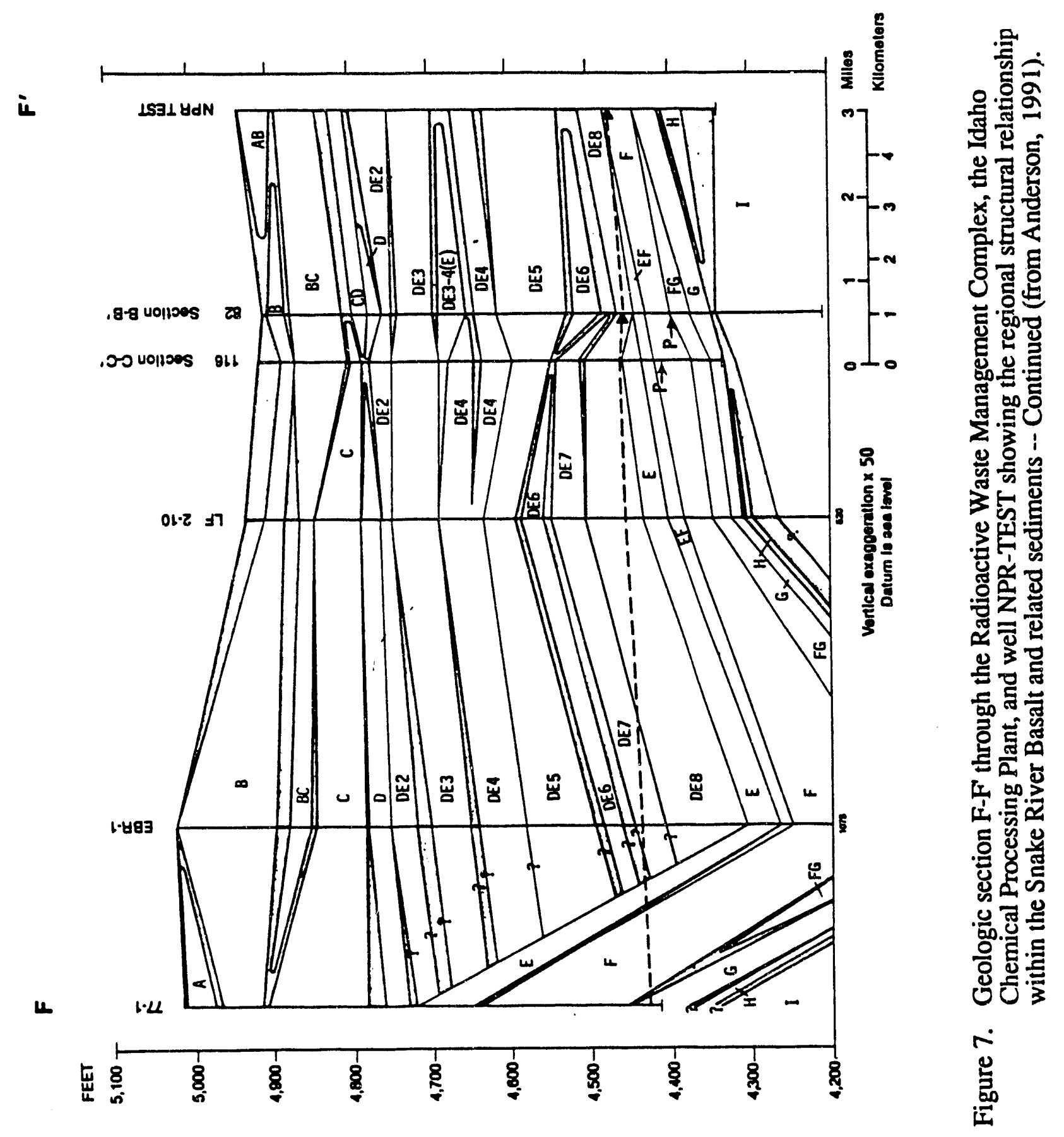


The basaltic volcanic rocks and interbedded sediments which comprise the upper portion of the regional aquifer are all included in the Snake River Group of Quaternary age. The effective base of the aquifer at the INEL is believed to coincide in places, with the top of a thick and widespread sequence of fine-grained sediments and basalt (Anderson, 1990; Anderson, 1991, p. 9). The upper contact of this sequence is observed at a depth of 1,220 feet in well INEL-1 (Mann, 1986) and at depths varying from 800 to 1,500 feet elsewhere on the site (Anderson, 1991).

\section{Recharge}

The principal source of recharge to the regional basalt aquifer beneath the INEL is underflow from the Mud Lake Basin, northeast of the site (Morris et al., 1963); from the Birch Creek valley and Little Lost River valley to the north and northwest, and from the Big Lost River. The latter provides a considerable source of recharge to the regional aquifer and overlying perched ground water systems in the vicinity of the ICPP during periods of high seasonal surface water run off (Robertson et al., 1974). Diversion structures have been installed upstream of the ICPP to reduce the risk of potentially damaging flood events caused by ice dams in the Big Lost River during late-winter run off events.

Minor amounts of recharge are also derived from local precipitation on the plain. Annual net precipitation ranges from 8 to 10 inches across the INEL with most precipitation occurring during the months of May and June. Rapid melting of the winter snowpack provides seasonal recharge to the perched water bodies. Recharge studies at the Radioactive Waste Management Complex (RWMC) suggest that less than 5 to 10 percent of the annual precipitation recharges the ground water system (Pittman, 1989). Waste 
water discharges to unlined infiltration ponds at selected INEL facilities also contribute minor amounts of recharge to the regional aquifer system (Robertson et al., 1974).

The irregular, broken, upper parts of flows and vertically jointed central and basal portions of unsaturated basalt flows provide conduits for water to infiltrate to the zone of saturation. Fine-grained surficial sediments locally restrict subsurface recharge to these unsaturated basalts and intercalated sediments. Infiltrating pore water may be temporarily perched and laterally dispersed on low-permeability, fine-grained, sedimentary interbeds located above the regional water table (see Figure 8).

Most of the water which enters the regional ground water system moves in a southwesterly direction through the aquifer, as shown on Figure 3; although locally, the ground water may flow in directions divergent from the overall regional flow direction. Regional discharge from the aquifer occurs within the channel of the Snake River and in numerous, high-yielding springs located along the canyon wall near Hagerman, Idaho (Mann, 1989).

\section{Ground Water Occurrence}

The interbedded basalts and sediments beneath the ICPP area are predominantly unsaturated to a depth of about 450 to 470 feet, although isolated perched water bodies exist locally within this interval. Perched water exists above a 30 to 40 foot thick, finegrained clastic interbed located at a depth of approximately 110 feet. A second, less prominent silt and clay horizon exists at about 370 feet below land surface. This fluvial interbed ranges from 10 to 30 feet in thickness and results in a relatively localized perched water body below the ICPP. A more detailed description of the nature and configuration of geologic units within the unsaturated zone and related perched aquifers is beyond the scope and intent of this report. The reader is referred to Jones (1961), Robertson et al. (1974), and Hull (1987) for a comprehensive discussion of the material properties, stratigraphic 


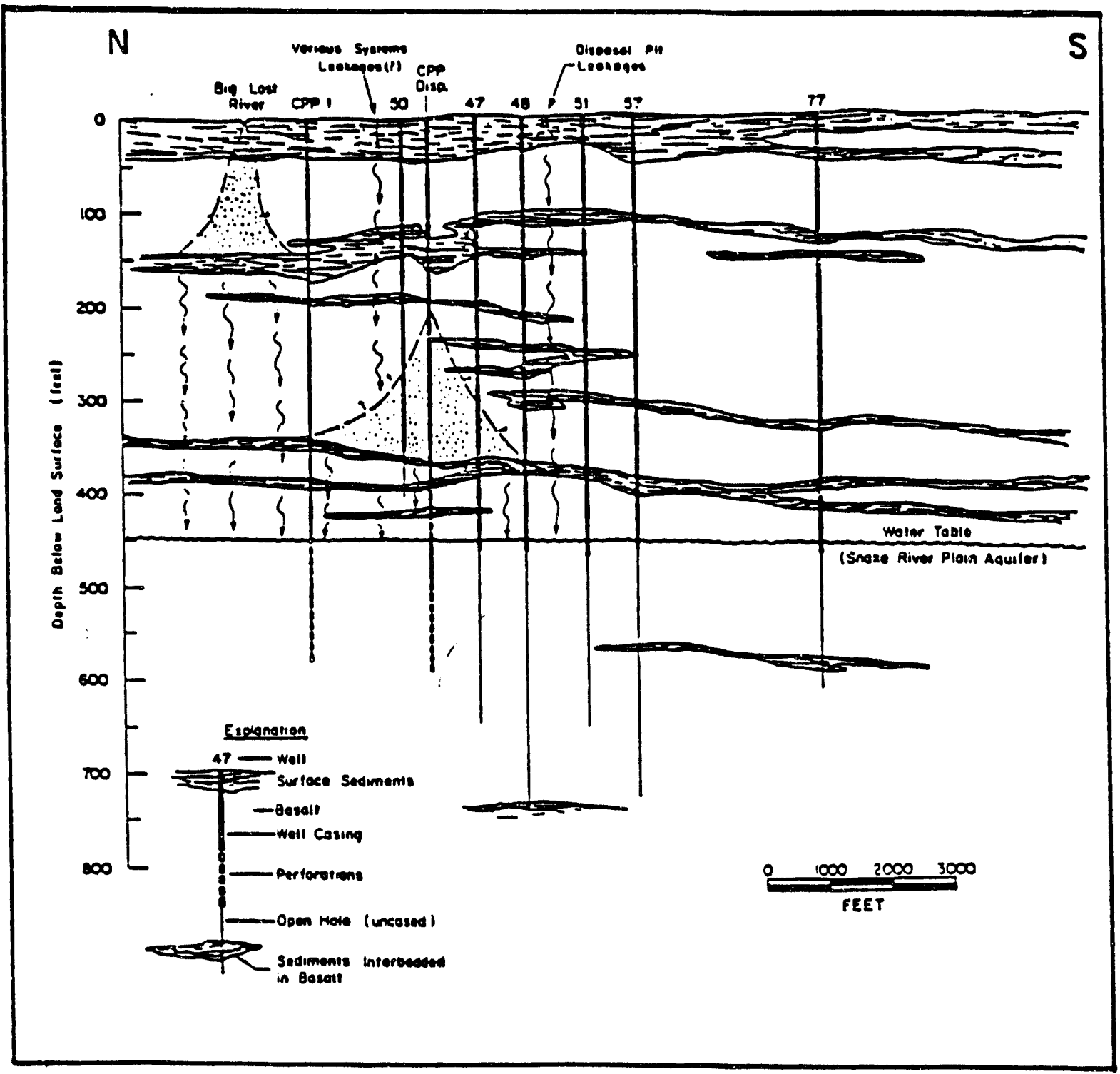

Figure 8. Geologic cross section from north to south through the ICPP area showing generalized stratigraphy, localized recharge sources, wells, and regional water table (from Robertson et al., 1974). 
relationships, and ground water occurrence above the regional water table in the vicinity of the ICPP. A geologically complex series of lithostratigraphic correlations within the unsaturated zone is also provided in Anderson (1991).

The regional ground water system is described as being under water table conditions (Ackerman, 1991, p. 4). However, the high horizontal to vertical hydraulic conductivity contrast causes deeper wells to respond in a semi-artesian manner (Morris et al., 1963). The occurrence of dense, low permeability flow interiors and fine-grained interbed sediments above and below highly permeable interflow zones result in locally semi-confined conditions. Water levels observed during well drilling operations have been noted to suddenly rise from 5 to 50 feet above the apparent point of penetration when saturation is not recognized in overlying dense basalt units (Nace et al., 1959; Morris et al., 1965). Significant water level fluctuations caused by changes in barometric pressure also suggest that parts of the ground water system are under semi-confined conditions (Morris et al., 1963). Barometric efficiencies of selected monitoring wells at the ICPP area are shown in Table 1. Water level responses to high discharge pumping tests, however, have been interpreted to indicate that the system is largely unconfined on a regional scale (Ackerman, 1991).

The regional water table below the INEL occurs at a depth of about 200 feet in the northeast and 900 feet in the southeast and has an average gradient of approximately 5 feet per mile to the southwest (Robertson et al., 1974). Depth to water in the area of the ICPP is about 450 to 470 feet. Highly localized hydraulic gradients and ground water flow vectors are difficult to establish with a high degree of certainty at the ICPP (Jones, 1961; Robertson et al., 1974); this is due to complex aquifer heterogeneicies, variations in head with depth, and the associated absence of water level data collected from piezometers completed through individual, distinct head zones. Regional-scale ground water quality mapping of contaminants such as tritium, strontium-90, and sodium, as well as specific conductance, have been used in defining generalized ground water flow directions across 
the site, especially at and down gradient of the ICPP and TRA (Barraclough et al., 1967b, p. 64-73; Robertson et al., 1974, p. 143-174; and subsequent USGS reports on the hydrolngic conditions of the INEL). These data suggest that ground water flow occurs in a south-southwesterly direction at the ICPP with a wide angle of lateral, hydrodynamic dispersion.

Table 1

Barometric Efficiencies of Selected Monitoring Wells at the ICPP Area (after Morris et al. 1963)

\begin{tabular}{|c|c|}
\hline $\begin{array}{c}\text { Monitoring Well ID } \\
\text { Number. }\end{array}$ & Barometric Efficiency \\
\hline 41 & $91 \%$ \\
\hline 42 & $92 \%$ \\
\hline 43 & $68 \%$ \\
\hline 44 & $81 \%$ \\
\hline 45 & $76 \%$ \\
\hline 46 & $76 \%$ \\
\hline 47 & $97 \%$ \\
\hline 49 & $68 \%$ \\
\hline 51 & $76 \%$ \\
\hline 52 & $73 \%$ \\
\hline 57 & $74 \%$ \\
\hline 59 & $63 \%$ \\
\hline 67 & $77 \%$ \\
\hline
\end{tabular}

Water-bearing openings in the basalt consist of intercrystalline and intergranular porespace, fractures, joints, cavities, interstitial voids, and interflow zones (Nace et al., 1956). Vesicular zones are common in most of the Snake River Basalt flows. Vesicles are not believed to represent significant pathways for ground water flow, with the exception of within highly fractured interflow zones, because of the otherwise limited hydraulic interconnection between adjacent vesicles. Vesicles may be minute to several tens of millimeters in diameter, and as much as several centimeters in length if elongate. Vesicles may exceed 25 percent of total rock volume, although 10 to 20 percent is common in the upper parts of most flows (Nace et al., 1975). 
Lava tubes are readily observable at the land surface in the vicinity of the INEL (Nace et al., 1975). However, these structures have not been positively identified at depth and are not expected to be fully preserved as water-bearing conduits within the upper portion of the Snake River Plain aquifer due to excessive overburden pressures at depth in the basalt stack (Nace et al., 1959).

Brecciated, vesicular, or rubbly flow tops are typically very porous and may exhibit high horizontal hydraulic conductivity (see Figure 5). Flow tops are therefore believed to represent the primary pathways for horizontal ground water movement through the basalt sequence below the INEL. Intraflow interiors may have moderately high porosity depending on the degree of vesicularity and jointing. However, the vertical and horizontal hydraulic conductivity of flow interiors is significantly less than in the overlying interflow zones due to the generally poor hydraulic interconnection between vesicles and joints. Vertical flow of ground water through basalt flow interiors generally is controlled by cooling joints, which are most commonly oriented perpendicular to basalt flow surfaces (Nace et al., 1975). Horizontally oriented fractures or joints are of little importance to the regional flow of ground water because these structures are rarely interconnected over large lateral distances (Mundorff et al., 1964; Nace et al., 1975). Flow bottoms typically exhibit moderate to high hydraulic conductivity depending on the cooling history of the lava (Lindholm and Vaccaro, 1988). Extremely high horizontal hydraulic conductivity may exist in interflow zones where flow tops and bases have coalesced without the presence of fine-grained interbed sediments and related in-filling of void spaces.

Near-vent facies pyroclastic debris (Knutson et al., 1990) or sedimentary material deposited on the surface of individual basalt flows during extended periods of volcanic iractivity may increase or decrease the transmissive properties of interflow zones (Jones, 1961). The hydrologic effects of these interbeds depend primarily on the texture and thickness of the clastic material, the physical characteristics of the flow top, and the extent of void infilling that takes place. Fine-grained sediment intercalated within a highly 
brecciated and irregular flow top will, in general, reduce the horizontal and vertical hydraulic conductivity of that interflow zone (Lindholm and Vaccaro, 1988).

The hydraulic conductivity of the sedimentary interbed materials is highly varied and depends on the mode and history of deposition, textural characteristics, grain-size distribution and compaction history. Hydraulic conductivities of common interbed sediments may range from $3.0 \times 10^{-4}$ (clay) to $3.0 \times 10^{3}$ (gravel) feet/day, with anisotropy ratios of 10 to 100 for the finer-grained materials (Freeze and Cherry, 1979). Numerical modeling studies at the INEL estimate the vertical hydraulic conductivity of typical interbed sediments to range from $9.8 \times 10^{-6}$ to $1.0 \times 10^{-1}$ feet/day (Robertson, 1977, p. 26). These data suggest that fine-grained clastic interbeds represent the most effective barrier to vertical ground water flow by comparison to vertically fractured basalt flow interiors.

Anisotropy of hydraulic conductivity is prevalent in the Snake River Group at the scale of the ICPP. Hydraulic conductivity is generally greater in the horizontal direction than in the vertical direction (Walton, 1958; Lindholm and Vaccaro, 1988; Ackerman, personal communication). One flow at the INEL is reported to have a horizontal to vertical hydraulic conductivity ratio of 3.7 to 1 (Barraclough et al., 1976a). Vertical hydraulic conductivity is lower due to the massive structure and lack of interconnected pore spaces within most basalt flow interiors. Fine-grained sedimentary interbeds may also impede the vertical movement of ground water and thereby act as confining beds where areally continuous.

Hydraulic conductivity is known to decrease with depth through the Snake River Group due to a reduction of the primary and secondary void spaces by overburden pressure and geochemical processes (Mann, 1986, see Table 2). Most ground water is believed to move through the upper 200 to 500 feet of the aquifer system along discrete interflow zones (Lindholm and Vaccaro, 1988). Horizontal hydraulic conductivity of the basalts within the Snake River Group varies considerably within individual flows depending on the nature and extent of intraflow structures. Horizontal hydraulic conductivity is reported 
to be as high as $9.8 \times 10^{3}$ feet/day and most commonly ranges from $4.9 \times 10^{2}$ to $4.9 \times 10^{3}$ feet/day (Lindholm and Vaccaro, 1988).

Table 2

Changes in hydraulic conductivity of geologic formations with depth in test well INEL-1 (after Mann, 1986)

\begin{tabular}{|c|c|}
\hline $\begin{array}{c}\text { Open Hole Interval } \\
\text { (feet below Surface) }\end{array}$ & $\begin{array}{c}\text { Hydraulic conductivity } \\
\text { (feet/day) }\end{array}$ \\
\hline $395-595$ & $1.2 \times 10^{3}$ \\
\hline $1511-2206$ & $3.0 \times 10^{-2}$ \\
\hline $3559-4879$ & $6.0 \times 10^{-3}$ \\
\hline $4210-10365$ & $2.0 \times 10^{-3}$ \\
\hline
\end{tabular}

Secondary alteration products such as iron oxides, ilmenite, and clay minerals commonly form along fracture surfaces in the Snake River Basalts. Precipitation of secondary calcite and silica within vesicles or other rock openings also occurs within the saturated basalts beneaih the INEL (Lindholm and Vaccaro, 1988). The hydraulic conductivity of interflow zones may be effectively reduced by such geochemical processes over extended periods of geologic time (Wood and Fernandez, 1988). 


\section{CHAPTER 3}

\section{DESCRIPTION OF ICPP WELL NETWORK}

Thirty-six wells have been completed in the upper portion of the Snake River Plain aquifer in the vicinity of the ICPP between 1951 and 1990. The locations of these wells are shown in Figure 2. Table 3 provides a completion summary for each well including: date of installation, purpose of completion, drilling method used, ground surface elevation, total completion depth, cased interval depth, depth of total penetration below the regional water table, length of open interval and depth of dedicated sampling pump below ground surface (bgs). Additional information on each well is provided in Jones and Jones (1952), Peckham (1959), Chase et al. (1964), Bagby et al. (1984), Golder Associates (1990) and U.S. DOE (1990a).

Wells CPP-1, -2 and -4 were drilled to supply process and/or drinking water to the ICPP facilities. Well CPP-3 was originally drilled as an injection well and has subsequently been plugged, as discussed in Chapter 2 . The remaining thirty-two monitoring wells have been completed for the purpose of obtaining geologic, hydrologic, and geochemical data within the upper portion of the Snake River Plain aquifer. Monitoring wells are currently being used to define the horizontal extent of the contaminated ground water plume which originates, in part, from ICPP waste disposal sites.

The location and completion specifications of these wells were determined by the USGS in cooperation with the U.S. DOE. The USGS is respunsible for collecting water quality (e.g., Bagby et al., 1985) and water level (e.g., Barraclough et al., 1984) data from these wells on a quarterly, semi-annual, or annual basis.

The monitoring wells have been installed using cable tool and air drilling methods. Cable tool drilling was used for all well completions prior to 1962. All subsequent wells 


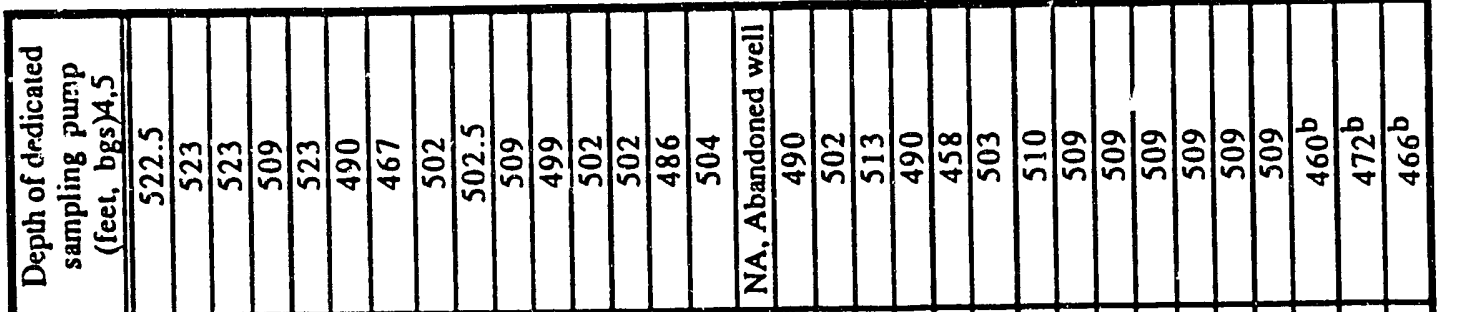

章官

ค

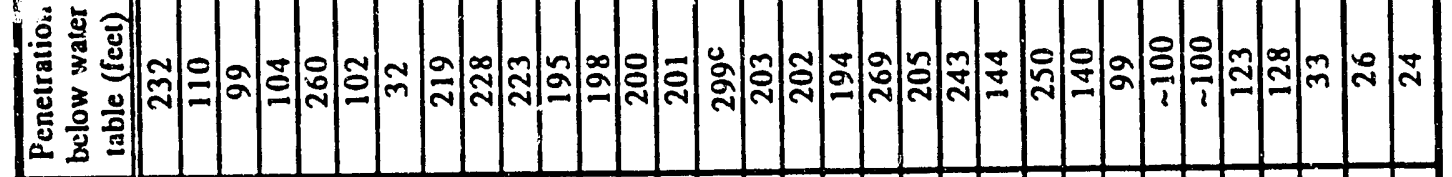

으.

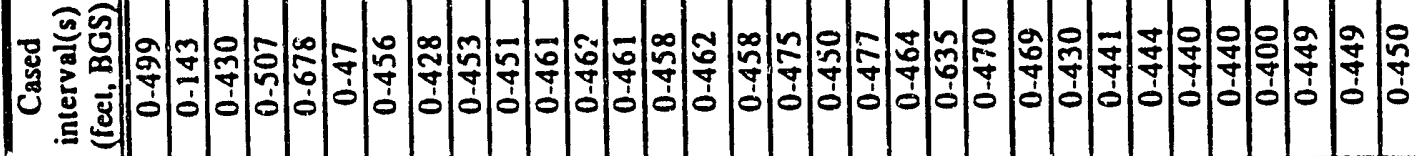

잉

릉

号

논

$0<$

.

통ํํ

은

造五

등

32

홍.

$5 \cdot \frac{0}{3}$

号

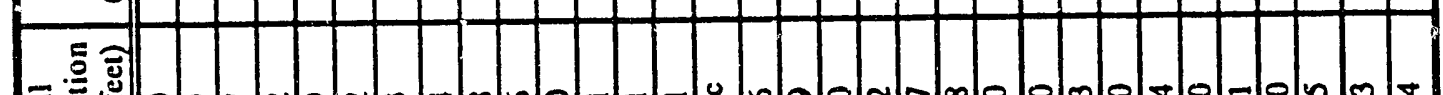

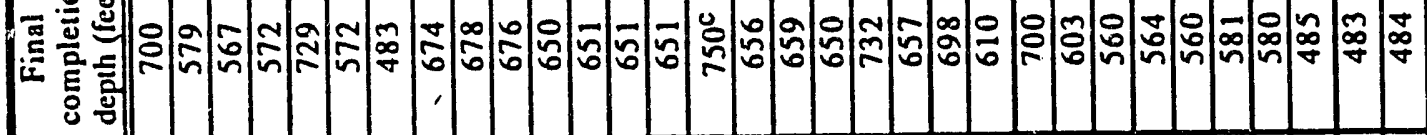

8

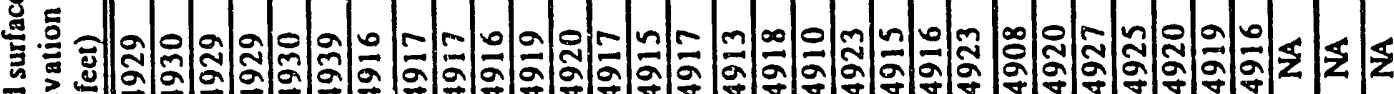
공 年

$\infty 0$

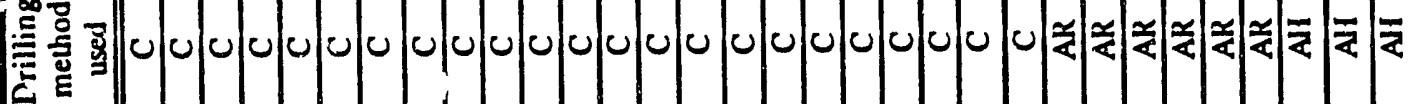

.

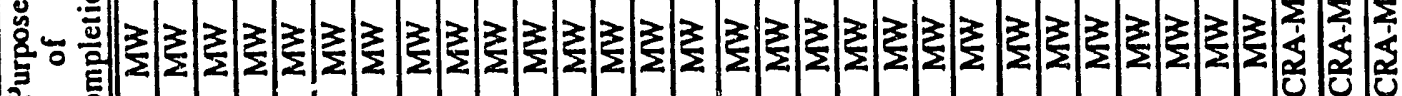

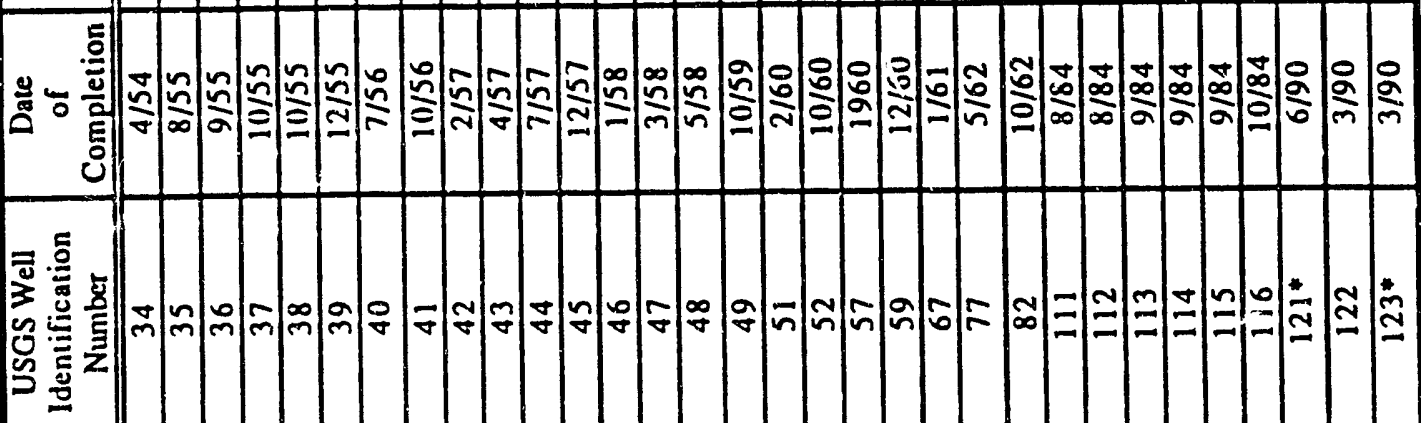



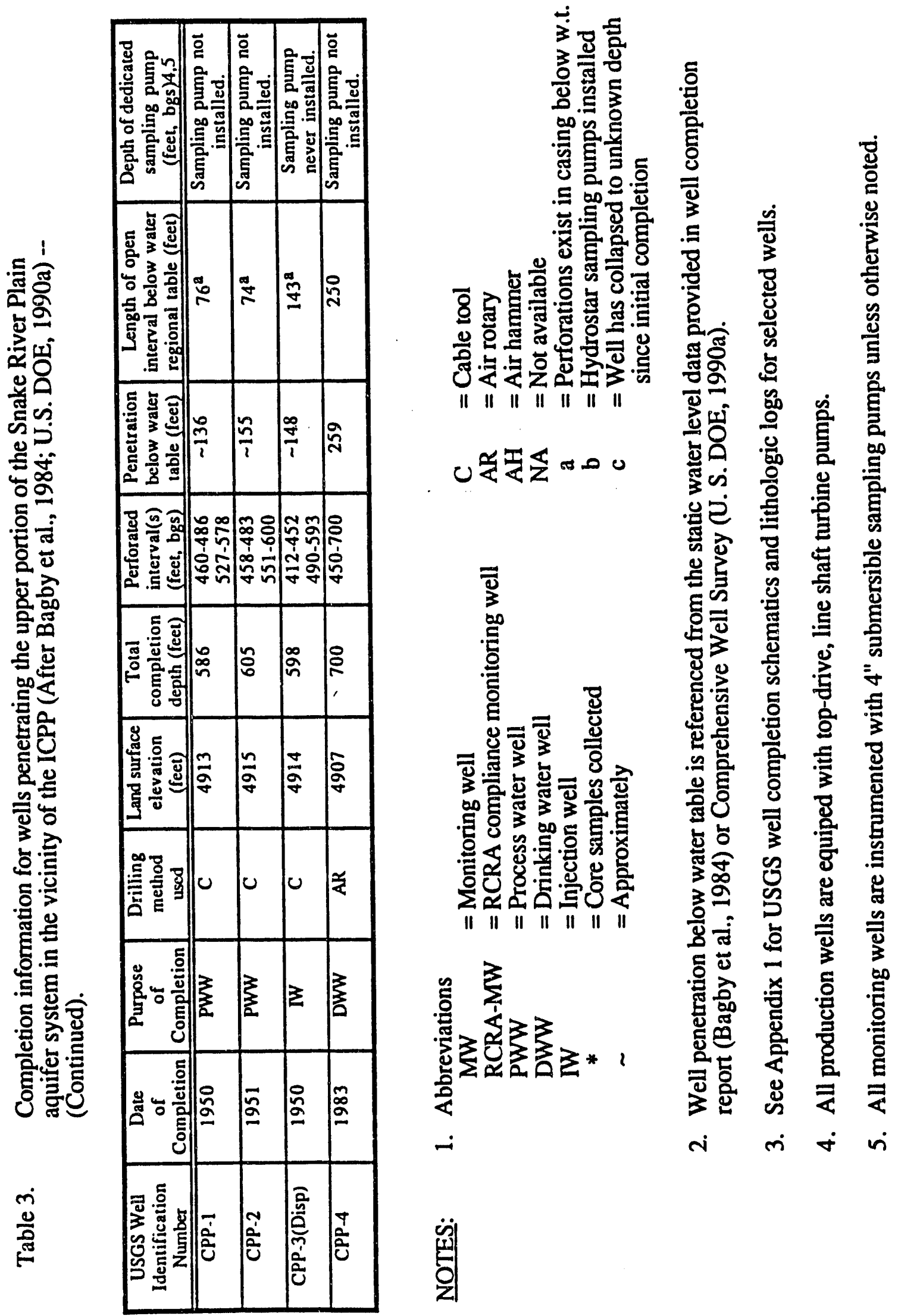
have been drilled using air rotary or air percussion methods. Air drilling provides rapid bit penetration, but does not provide the detailed cutting recovery typically associated with cable tool drilling methods (Driscoll, 1986). Lithologic descriptions obtained from drill cuttings have consequently been highly generalized for the more recently completed monitoring wells. Different drilling methods appear to influence the geometries of the finished open borehole intervals as discussed in Chapter 5 of this report. Core sampling at the ICPP has been conducted only in monitoring wells 121 and 123 (Golder Associates, 1990).

Total depth of ICPP wells ranges from 483 to 732 feet (wells 122 and 57, respectively). The mean depth of penetration below ground surface is 637 feet. Drilled borehole diameters in monitoring wells range from 4 to 8 inches although hole diameters of up to 40 inches may occur in localized zones of highly fractured basalt and unconsolidated sedimentary material (Chase et al., 1964).

Most of the ICPP monitoring wells are open to multiple water-bearing zones. Large uncased intervals, ranging from 100 to as much as 300 feet, commonly exist below the water table in many of the older monitoring wells. The mean open interval length in monitoring wells completed prior to 1990 is 156 feet. The three monitoring wells drilled since 1990 (USGS 121, 122, and 123) have a mean open interval length of approximately 28 feet and are screened just below the regional water table (Golder Associates, 1990). These wells were completed specifically for compliance ground water monitoring at the ICPP facility under Resource Conservation and Recovery Act (RCRA) guidelines and are not representative of the monitoring well network as a whole.

Generalized lithologic logs have been drawn for most ICPP wells (see Chase et al., 1964; Golder Associates, 1990). An unpublished compilation report of these logs is on file at the Idaho Water Resources Research Institute (TWRRI, 1991). Lithologic logs have generally been constructed based on drillers' and geologists' logs of representative drill cuttings returned to the land surface. The accuracy of these logs for all but wells 121 
though 123 is considered to be extremely variable and should only be relied on where other information is not available (Keys, 1963, p. 15). The correctness of the available lithologic logs is highly dependent on the driller's ability to interpret the action of the bit and to take representative samples and interpret them reliably. Although the driller is typically able to differentiate between sediment and basalt, this is rarely adequate for identifying detailed lithologically and hydrologically significant changes in basalt stratigraphy. Continuous core samples, such as those collected in wells 121 and 123, provide the most precise information on the locations and lithologies of individual basalt flows and related sediments at depth.

The USGS has conducted extensive, down-hole geophysical logging in most of the ICPP area wells (Bartholomay, 1990). Table 4 presents a summary of the types of geophysical logs available for wells completed in the upper portion of the Snake River Plain aquifer in the vicinity of the ICPP. Geophysical data have been used extensively for correlating apparent hydrostratigraphic zones (Jones, 1961) and lithostratigraphic units (Anderson, 1991) between selected wells at the ICPP. Many of these logs are available from the USGS INEL field office in digitized form on magnetic tape and have been used for evaluating the data presented in Chapters 5 through 7 of this report. 


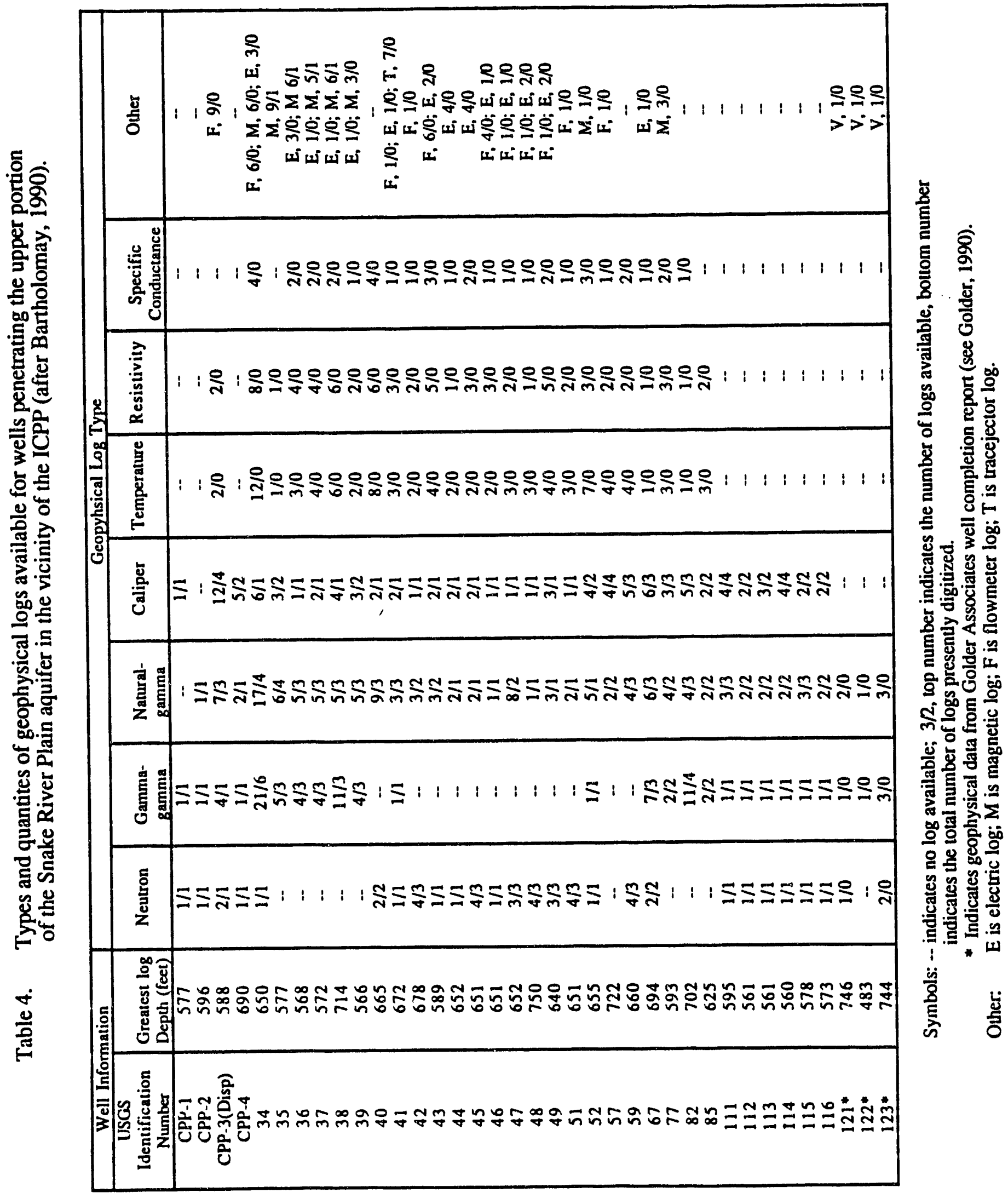




\title{
CHAPTER 4
}

\section{PRESENTATION OF CONCEPTUAL GEOLOGIC MODELS}

\author{
Introduction
}

Two conceptual models have been published to date by the USGS to describe the geology of the upper portion of the Snake River Plain aquifer at the ICPP area. The hydrostratigraphic conceptual model by Jones (1961) describes the spatial distribution of water-bearing zones and the pattems of ground water and waste movement through these interpreted hydraulic conduits. More recent work by Anderson (1991) describes a lithostratigraphic conceptual model of the complex sequence of basalts and related sedimentary interbeds underlying both the ICPP and TRA, but is not intended to characterize the occurrence or movement of ground water through the regional aquifer system. The conceptual frameworks and underlying assumptions of these models are discussed in this chapter.

\section{Hvdrostratigraphic Model of Jones (1961)}

Jones (1961) developed a localized, multiple-aquifer, conceptual model for the upper 200 feet of saturated basalts and related sediments in the vicinity of the ICPP. Lithologic and selected geophysical logs from 15 wells drilled prior to 1960 were used to define up to five locally distinct aquifers below the regional water table. Aquifers are identified as highly permeable interflow zones siruated between dense, massive basalt flows. Jones was able to correlate graphically some of these aquifers between wells separated by lateral distances of just over a mile. Preliminary straddle-packer experiments 
and depth-specific water quality measurements were used to illustrate semi-quantitatively the hydrologic conditions in one isolated aquifer zone (Jones, 1961, p. 41-56).

\section{Geophysical Logging Methods Used}

Jones uses natural-gamma and hole diameter (caliper) logs as the primary tools for interpreting and constructing the hydrostratigraphic model. A brief description of the theory behind these geophysical logs is provided below. The reader is referred to Chase et al. (1964), Goldstein and Weight (1982), and Keys (1989) for more comprehensive discussions of geophysical logging theory, methods, and application.

\section{Natural-Gamma Logs}

A natural-gamma log is a record of gamma radiation emitted by naturally occurring radioisotopes within the geologic medium under consideration (Keys, 1989). A sodiumiodide scintillation gamma-radiation detector is used in the gamma sonde for recording the natural emission intensity as the tool is raised up the borehole (Goldstein and iveight, 1982). Natural radioisotopes in basalts at the INEL include potassium-40, bismuth-214, lead-214, actinium-228, thorium-232 and uranium-238 (Barraclough et al., 1976a). Sedimentary materials at the INEL contain greater concentrations of naturally occurring radioisotopes, especially $\mathrm{K}-40$, and therefore generally display high gamma-ray intensities when compared to Snake River Basalts (Anderson and Bartholomay, 1990). Total gamma radiation is measured without distinguishing between individual contributions from the various radioisotopes present. Higher levels of gamma radiation register positively on the right side of the log whereas lower emissions appear on the left as negative deflections.

The gamma-ray intensity of Snake River Basait logged in a 6-inch diameter borehole is generally less than 0.005 milliroentgen per/hour $(\mathrm{mr} / \mathrm{hr})$, whereas the gamma- 
ray intensity of loess varies from approximately 0.0075 to $0.0125 \mathrm{mr} / \mathrm{hr}$ (Jones, 1961). Interbeds containing cinders, scoria, silt and sand therefore show a wide range of gammaray intensities due to their compositional heterogeneities with depth.

\section{Caliper Logs}

Caliper logs record the drill-hole diameter in the uncased part of the borehole as well as the inside diameter of the well casing. The caliper tools used at the INEL contain three extendable feeler arms which are mechanically coupled to trace the wall of the borehole. These logs are generally accurate to the nearest inch when properly calibrated although some of the "older logs" may be in error by 2 inches or more (Chase et al., 1964). The caliper log is used to identify major lithologic changes, locate fractures and cavernous zones, and to aid in the interpretation of diameter-dependent nuclear logs. Caliper logs may also be useful during well construction for determining where to set casing, grout/cement, or place filter packing materials (Keys, 1989). Factors which may influence the hole diameter measured by caliper logs include the drilling method used, lithology, fracturing, material porosity, and caving, sloughing, or washouts in poorly consolidated sedimentary zones.

\section{Methods of Correlation}

Caliper logs are used by Jones (1961) to assist in identifying lithologic changes both within and between basalt flows. The relatively dense, unfractured flow interiors and more competent flow bottoms yield hole diameters only slightly larger than the 6-inch drill bits generally used for deep cable tool drilling. Borehole diameters are typically an inch to two inches larger than effective bit size in thick beds of cinders and small scoria, and several inches greater than bit size within interflows containing large fractures, flow 
breccia, and clinker zones. Interpreted water-bearing zones (aquifers) therefore appear at least two to three inches larger than the effective bit size. Beds of unconsolidated sediment and/or cinders overlying zones of dense basalt tend to show large borehole enlargements. This is due to the repeated impact (and vibration) of the drilling bit on the more competent, underlying flow, combined with the "slapping" effect of the drilling cable against the overlying sedimentary zones.

Jones identifies and correlates discrete aquifers in ICPP monitoring wells based on a comparative evaluation of caliper and natural-gamma logs and lithologic (drillers') data. Borehole intervals showing extensive enlargements on caliper logs often exhibit naturalgamma intensities characteristic of sedimentary material and are inferred to have relatively low hydraulic conductivity. Borehole intervals showing comparatively low gamma-ray intensities and borehole enlargements of greater than 2 inches over effective bit size generally contain little sediment and are believed to be highly productive aquifers in Jones's interpretation. The lithology, texture, and stratigraphic position of a given basalt flow unit, as determined from drillers logs, are also be used by Jones (1961) to interpret the relative hydrologic characteristics of that material.

\section{Discussion of Model Results}

Zones of scoria, cinders, and flow breccia located between dense basalt layers are correlated by Jones (1961) throughout the ICPP area. Five principal aquifers are identified and mapped by Jones in the depth interval between 460 and 660 feet. Table 5 reproduces the interpreted depth, altitude, and thickness of aquifers identified by Jones within fifteen of the pre-1960 monitoring wells. Lateral hydrostratigraphic correlations are based "...largely on the caliper $\log$, which shows a high degree of similitude for the same lava- 


\begin{tabular}{|c|c|c|c|c|c|c|c|c|c|c|c|c|c|c|}
\hline 总 & & $\bar{v}$ & N & - & 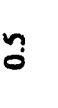 & $\vec{v}$ & $\simeq$ & & 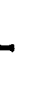 & & - & $\tilde{q}$ & & \\
\hline 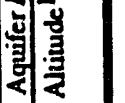 & హั & 鲂 & 品 & 覃 & 筞 & 鄗 & 章 & 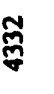 & 商 & 尼 & 唒 & 兹 & $\frac{D}{n}$ & สี้ \\
\hline 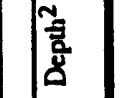 & $\tilde{\kappa}$ & ఐే & 离 & ద & ڤొ & ๓ & E & ஜ̊. & దొ & & 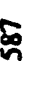 & శ్ & & ڤू \\
\hline 量 & $\cong$ & $n$ & $\tilde{\omega}$ & 7 & $\bullet$ & $\simeq$ & $N$ & $n$ & 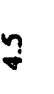 & N. & $\bar{v}$ & $\beth$ & & $\vec{v}$ \\
\hline 堂 & 第 & 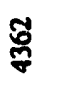 & 今े & : & 鸟 & 萼 & 莺 & ఫ్య & 彥 & \% & 耪 & 号 & & 两 1 \\
\hline $\int \frac{5}{8}$ & ถึ & $\hbar$ & $\bar{n}$ & 욤 & ڤ̆ & $\tilde{n}$ & $\tilde{n}$ & $\bar{n}$ & 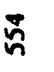 & I̊ñ & ถี้ & $\tilde{n}$ & & 号 \\
\hline 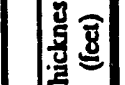 & $\stackrel{n}{\infty}$ & - & N & - & - & 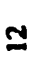 & $\sigma$ & N & $\vec{v}$ & - & $\vec{v}$ & $\underline{n}$ & $\tilde{N}$ & $\stackrel{n}{i}$ \\
\hline 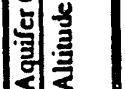 & 岁 & 兽 & 旁 & హ్ & बू & 幾 & है & 兽 & है & 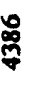 & \&్ & 骂 & & 总 \\
\hline 管 & $\stackrel{\circ}{n}$ & $\approx$ & $\stackrel{\circ}{n}$ & ซึี & $\tilde{\tilde{n}}$ & $\approx$ & 윰 & $\approx$ & हี & 危 & $\tilde{n}$ & ซี้ & 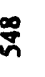 & $\bar{n}$ \\
\hline 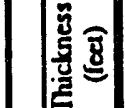 & - & 1 & $\underline{n}$ & $\vec{v}$ & + & - & m & $r$ & $\beth$ & $\vec{v}$ & $\tilde{\kappa}$ & $\bar{v}$ & 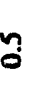 & $\bar{v}$ \\
\hline 袅害 & סू & 1 & बू & ळू & 荤 & $\bar{\sigma}$ & 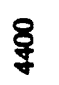 & 豆 & 8 & 辑 & 宗 & 呆 & 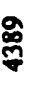 & 桑 1 \\
\hline 誓 & मे & 1 & $\approx$ & ฉ్ ี & $\stackrel{0}{n}$ & 율 & ลे & $\bar{n}$ & $\frac{a}{n}$ & $\overline{\bar{n}}$ & $\stackrel{n}{n}$ & $\approx$ & $\tilde{\xi}$ & $\frac{m}{n}$ \\
\hline 憘 $\widehat{\underline{z}}$ & 1 & - & 0 & $\simeq$ & $\cong$ & $\sigma$ & $n$ & ָุ & $\cong$ & $\cong$ & $\vec{v}$ & - & 1 & $n$ \\
\hline : & 1 & $\frac{a}{\xi}$ & $\frac{\infty}{\xi}$ & $\bar{\xi}$ & 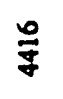 & 亦 & $\stackrel{\infty}{\ddagger}$ & $\bar{\xi}$ & $\frac{m}{\xi}$ & $\bar{\ddagger}$ & $\frac{0}{7}$ & ‡ & 1 & $\bar{\ddagger} \bar{\ddagger}$ \\
\hline 旅 & 1 & 8 & ธี & 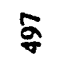 & 气ั & ప్ & $\bar{n}$ & Б్ & ६ & 气ิ & \& & $\tilde{\alpha}$ & 1 & 气े \\
\hline 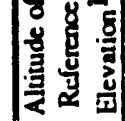 & $\vec{\sigma}$ & $\frac{a}{\sigma}$ & ఫ్ & $\frac{\infty}{\sigma}$ & $\bar{\sigma}$ & $\bar{\sigma}$ & $\frac{a}{\sigma}$ & $\frac{\infty}{\sigma}$ & $\frac{a}{\partial}$ & $\frac{0}{\sigma \sigma}$ & ฐ & $\frac{m}{\alpha}$ & ప్ & 음 \\
\hline 缘灵主方 & m & $\bar{\sigma}$ & $\approx$ & 7 & $\mp$ & $q$ & \& & $F$ & $\underset{\sigma}{\sigma}$ & F & $\bar{n}$ & กี & $\tilde{n}$ & ถి \\
\hline
\end{tabular}


top materials from well to well." (Jones, 1961, p. 29). The degree of hydraulic interconnection between the zones identified by Jones and the hydrologic properties of such intervals have not been documented by independent work. Jones constructed three highly interpretive hydrogeologic cross sections through the upper portion of the regionally saturated zone. The locations of the section lines and the monitoring wells used by Jones (1961) are shown on Figure 9. These cross sections, reproduced as Figures 10 through 12 , describe the possible spatial distribution of interflow aquifers below the ICPP.

The coalescing character and lateral pinchouts of aquifers as interpreted by Jones suggest that fractured basalt flow tops are commonly laterally discontinuous and/or exhibit considerable textural and lithologic variation at the scale under consideration. Aquifers "B", "C", and "D" are shown to pinch out laterally to the southeast based on Figure 11. Aquifers " $\mathrm{A}$ " and " $\mathrm{E}$ " are interpreted to be laterally continuous to the southeast, although the 4-inch diameter casing installed in the bottom of well 67 prohibits effective caliper log interpretation at this end of this section line. Aquifers " $C$ " and " $D$ " coalesce in the center of the Figure 11, suggesting that two separate flow tops may have joined in the area of wells 47 and 49. Coalescing of aquifers "C" and "D" is also observed near well 45 on Figure 10. Seemingly excellent lateral continuity is interpreted for the remaining aquifers shown in Figures 10 and 12, especially to the southwest ends of the sections. A slight regional dip to the southwest is suggested although "no evidence of structural deformation was found in the ICPP area" (Jones, 1961, p. 30).

Jones's hydrostratigraphic conceptual model is built on the assumption that geometric similitude of caliper logs is sufficient evidence to demonstrate sparial continuity of hydrologically distinct interflow zones. These intervals of pronounced borehole enlargement are assumed to be orders of magnitude more permeable than the surrounding unfractured basaltic strata (Jones, 1961, p. 19). Basalt stratigraphic units showing borehole enlargements of less than two inches over effective bit size are assumed to represent hydrologically insignificant aquifers by comparison to the adjacent flow tops. 


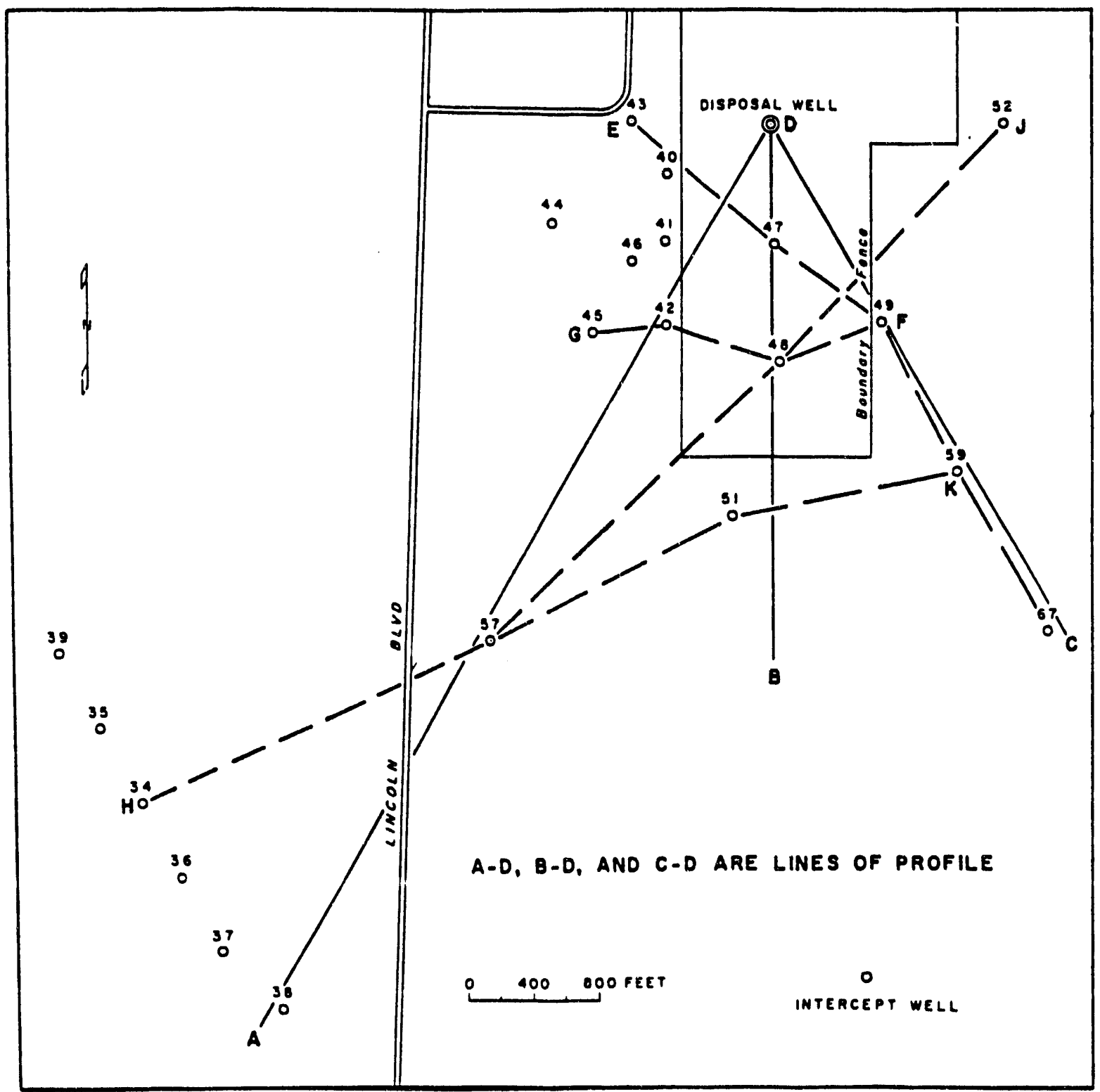

Figure 9. Generalized map of the ICPP area showing the locations of wells, profiles, and cross sections used by Jones (1961). 


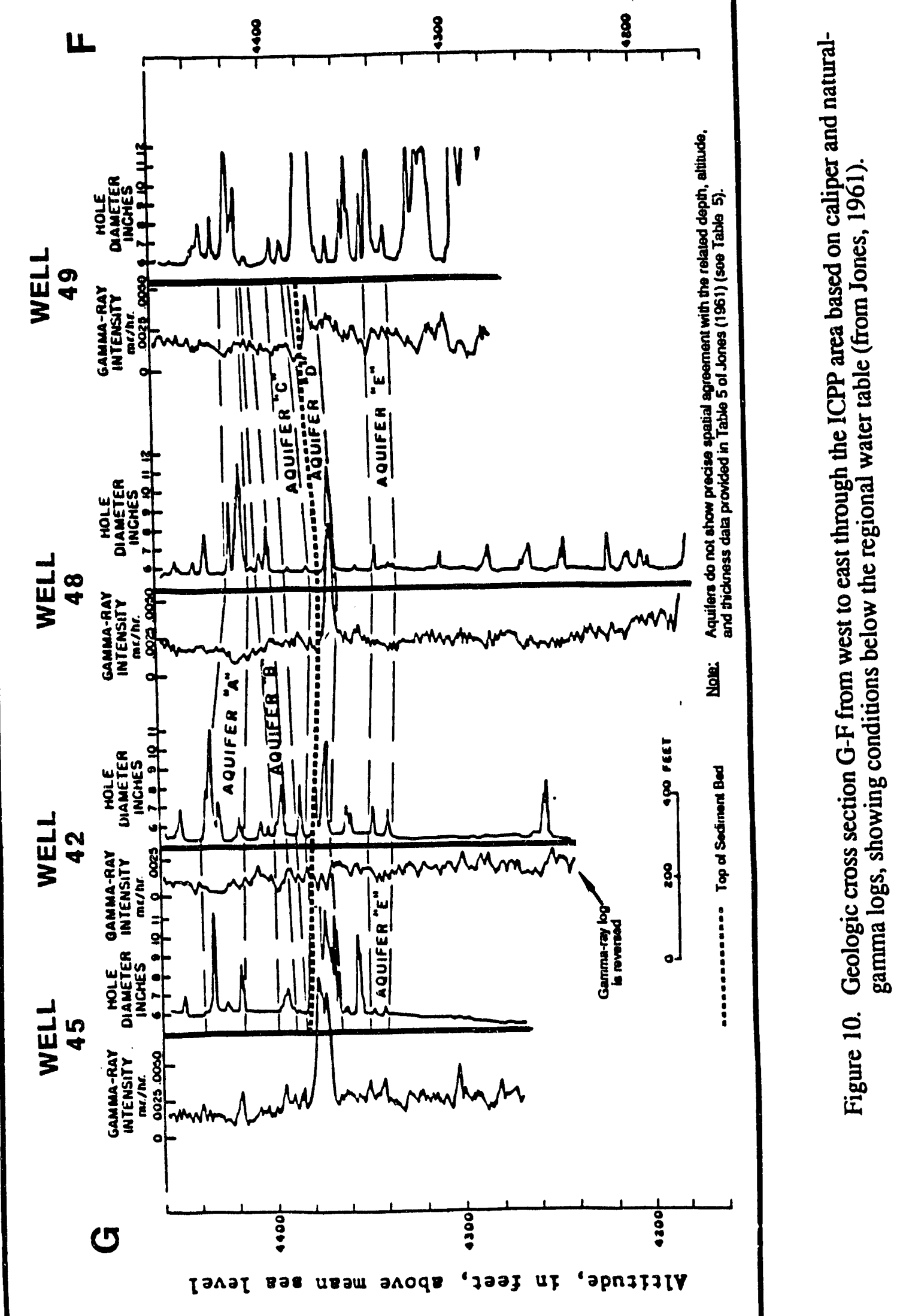




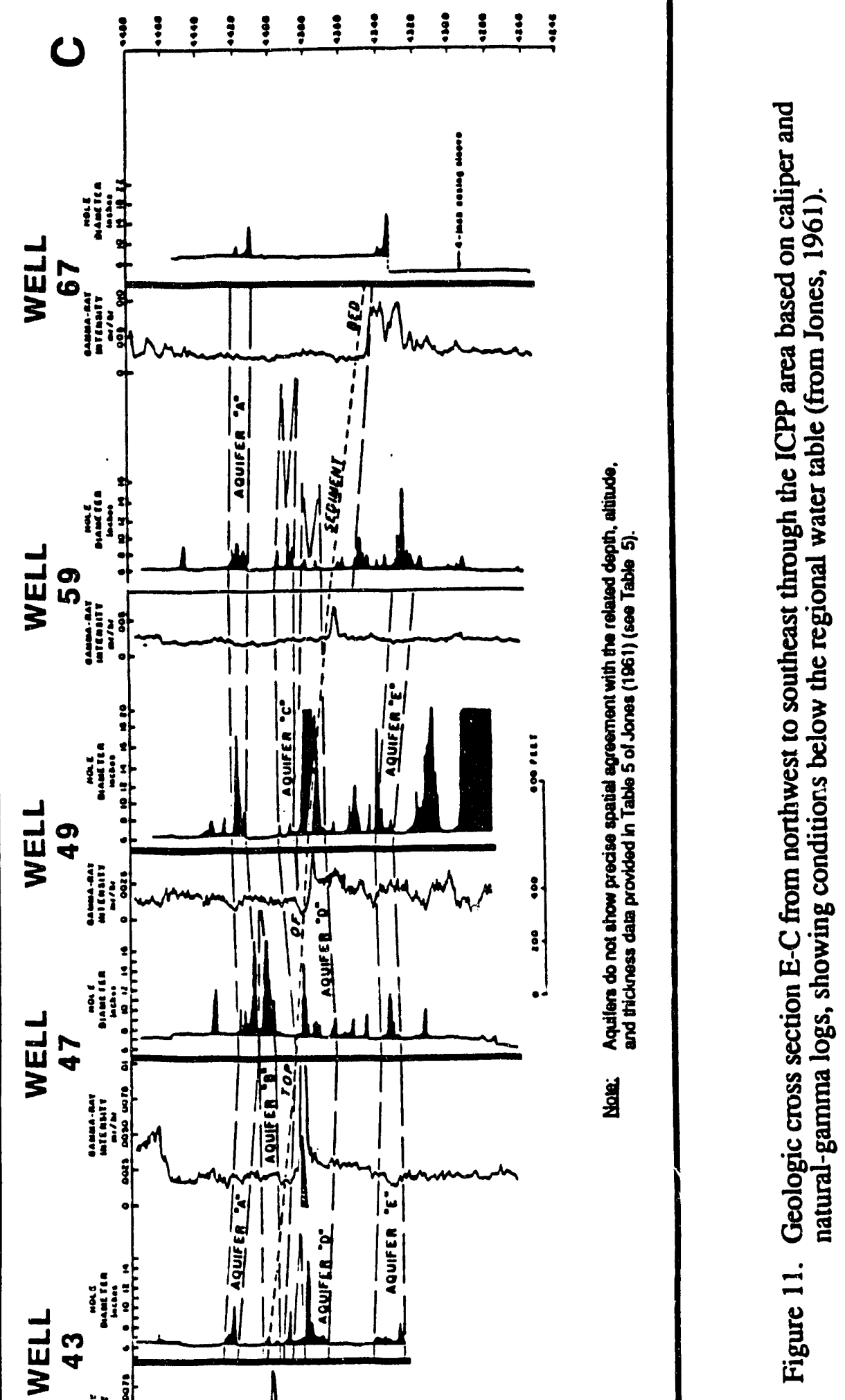




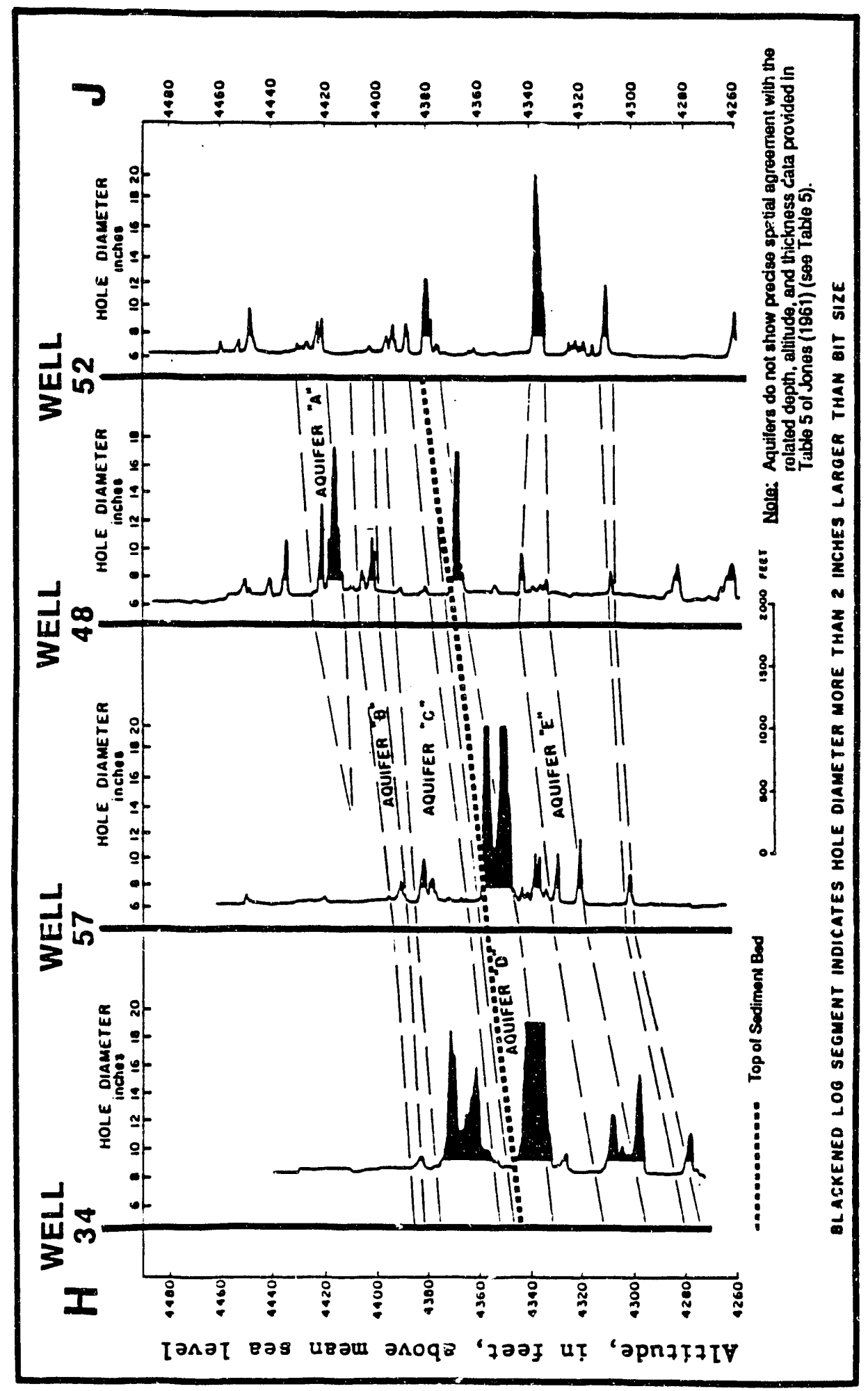

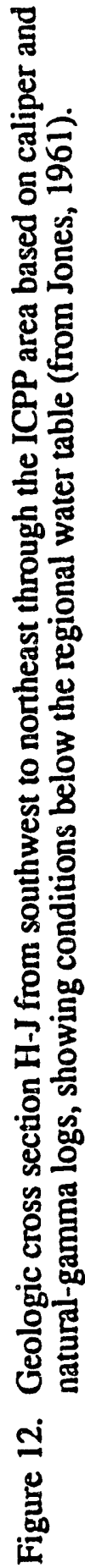


The interflow aquifers delineated in each well are assumed to represent time-stratigraphic equivalents across the ICPP area. This implies that regionally continuous sedimentary marker-beds should also conform to the structural geometry defined by the basalt interflow stratigraphy. A layer of sediment, generally consisting of clay, silt, ash or red sand with cinders, is mapped by Jones (1961) over most of the ICPP area at depths of between 515 and 572 feet, based on lithologic and natural-gamma logs (also see Anderson, 1991). This interval is exceptionally well defined by natural-gamma logs shown on Figures 10 and 11 . The upper sediment surface is also shown in Figure 12 although the natural-gamma logs are not presented. The spatial configuration of this interbed closely matches the basalt structure defined by flow top aquifers in Figures 10 and 12 and is interpreted by Jones as representing a time-stratigraphic depositional surface. However, in Figure 11 the depositional surface described by this sediment bed is highly discordant to the interpreted basalt stratigraphy and fully cross-cuts flow top aquifers "B", "C", and "D". Jones did not present depositional and/or tectonic processes likely responsible for creating the stratigraphic configuration shown in Figure 11 (Jones, 1961, p. 30). The existence and well defined orientation of this sediment bed is inconsistent Jones's interpretation that aquifers " $B$ " through " $D$ " exist as laterally continuous, time-stratigraphic interflow zones throughout section E-C (Figure 11).

Inflatable straddle-packers were used by Jones (1961) to hydraulically isolate aquifer " $D$ " within fourteen of the ICPP monitoring wells. A valve system within the packer-head assembly allowed for the measurement of water levels above, between, and below the straddled interval. Jones reports that hydraulic head differences of a few tenths of a foot are common between these intervals, but in no instance is the difference greater than three feet (Jones, 1961, p. 41). Marked differences exist between the water level contour maps constructed using data from multiple-aquifer well completions and similar maps conducted from single-aquifer completions within aquifer " $D$ ". Jones attributes these differences to spatial variations in the extent, thickness, and hydraulic properties of the 
aquifers tapped by each monitoring well and to the resultant ground water flow which may occur between separate aquifers (Jones, 1961, p. 39). Jones therefore concludes that meaningful water level contour maps cannot be constructed using hydraulic head measurements from multiple-aquifer well completions, as these data represent a composite measurement of hydraulic head within all of the aquifers intercepted by individual boreholes.

Downhole temperature profiles are described and evaluated by Jones (1961) for selected wells within the ICPP well network. These data show that injected wastes rose to the top of the "A"-" $E$ " aquifer sequence because waste water temperatures were considerably higher than the ambient ground water temperature of 52 to $64^{\circ} \mathrm{F}$ (Jones, 1961, p. 50). These data lead Jones to suggest that the less dilute, higher temperature wastes may have been transported greater distances within the upper portion of the regional aquifer system, primarily within aquifers " $A$ " through " $D$ " (Jones, 1961, p. 50). Specific conductance profiles completed by Jones (1961) within each of the ICPP monitoring wells also suggest that aquifers " $\mathrm{A}$ " through " $\mathrm{D}$ " act as the main conduits for contaminant transport (Jones, 1961, pp. 49-51). These data demonstrate that waste water migration occured in southeasterly and southwesterly directions from the disposal well, with ground water flow lines diverging in the vicinity of well 51 (Jones, 1961, p. 52). Jones concludes that the movement of aqueous wastes from the disposal well was controlled principally by the spatial geometry and cumulative thickness of the multiple-aquifer system.

Selected chemical and physical characteristics of ground water from aquifer " $D$ " were determined by Jones (1961) using wells recompleted with straddle-packers within only that aquifer. These data demonstrate that aquifer " $D$ " had a higher dissolved chloride content than the overlying and underlying composite water-bearing zones (Jones, 1961, p. 43). Sodium concentrations within aquifer " $D$ " lead Jones to conclude that "...aquifer " $D$ " is the most important aquifer in the system ... as it had the greatest influence on waste movernent before packers were installed." (Jones, 1961, p. 56). This statement is based 
on graphical similarities between the sodium-content maps for aquifer " $D$ " and similar maps constructed for the multiple-aquifer system. Tritium and sodium concentration distributions within aquifer " $D$ ", in combination with the aquifer " $D$ " isopach map, all support the conclusion that aquifer " $D$ " acts as the primary pathway for waste water transport at the ICPP, with wastes migrating in southeast and southwest direction from the disposal well (Jones, 1961, p. 57).

\section{Lithostratigraphic Model of Anderson (1991)}

Anderson (1991) developed a detailed lithostratigraphic model describing the spatial distribution of basalt flows and related sediments within the unsaturated zone and upper 300 feet of the Snake River Plain aquifer underlying the ICPP and TRA. Natural-gamma logs and lithologic data from 37 wells penetrating the uppermost part of the aquifer are used to identify and correlate distinct basalt flow groups and sedimentary interbeds at depth. The location of wells used by Anderson (1991) is shown in Figure 2 of this report.

\section{Methods of Correlation}

The areal extent and vertical distribution of basalt flow groups and sedimentary interbeds are interpreted by Anderson (1991) from natural-gamma logs, lithologic logs, and well core data collected through May, 1990. Natural-gamma logs are used as the primary tool for developing stratigraphic correlations between individual basalt flow groups below the regional water table. Potassium-argon ages, paleomagnetic properties, and petrographic characteristics determined for saturated basalt flows sampled in one nearby well core, NPR-TEST, are also used. This core hole is located nearly 3 miles east of the ICPP (see Figure 6 and 7). Regional-scale stratigraphic control is provided between core 
holes by a well defined section of basalt (flow group $F$ ) exhibiting a distinct paleomagnetic reversal and comparatively high natural-gamma emissions (Anderson, 1991).

\section{Discussion of Model Results}

As many as seven distinct basalt flow groups, designated DE8, E, EF, F, FG, G and $\mathrm{H}$, have been interpreted by Anderson (1991) to exist in the upper portion of the regional aquifer penetrated by the ICPP well network (see Figures 13 through 20). A basalt flow group is defined as "a sequence of one or more petrographically similar flows or flow units that were formed by lava extruded from the same vent or magma source within the course of a single eruption or multiple eruptions during a relatively short interval of time" (Anderson, 1991, p. 9). Flow groups DE8, E and EF each consist of one or two individual flows at the ICPP area, whereas F, FG, G, and $\mathrm{H}$ are each comprised of a single flow. The base of the composite stratigraphic unit consisting of flows groups $E$ through $\mathrm{H}$ includes the areally extensive, fine-grained sedimentary interbed previously recognized by Jones (1961). This interbed conformably overlies flow group I in most wells. Flow group I and related sediments consist of two or more massive, undifferentiated basalt flows below the ICPP. The basal geometry of group I flows and the stratigraphy of the underlying basalt units are uncertain due to the lack of test wells completed to this depth.

Exact depths of stratigraphic contacts between individual basalt flow groups are not explicitly provided by Anderson (1991) because of the interpretational nature of the naturalgamma log analysis (Anderson, personal communication). Contact elevations between flow groups within individual wells are specified only for "distinct" breaks between composite stratgraphic units as observed on natural-gamma logs (Anderson, 1991, Table 1, p. 66-71). These contacts generally correlate with areally extensive sedimentary interbeds. Specified contact elevations within the saturated zone include the upper surface of flow group I and the interface between flow groups DE-8 and E. Elevations of all other 


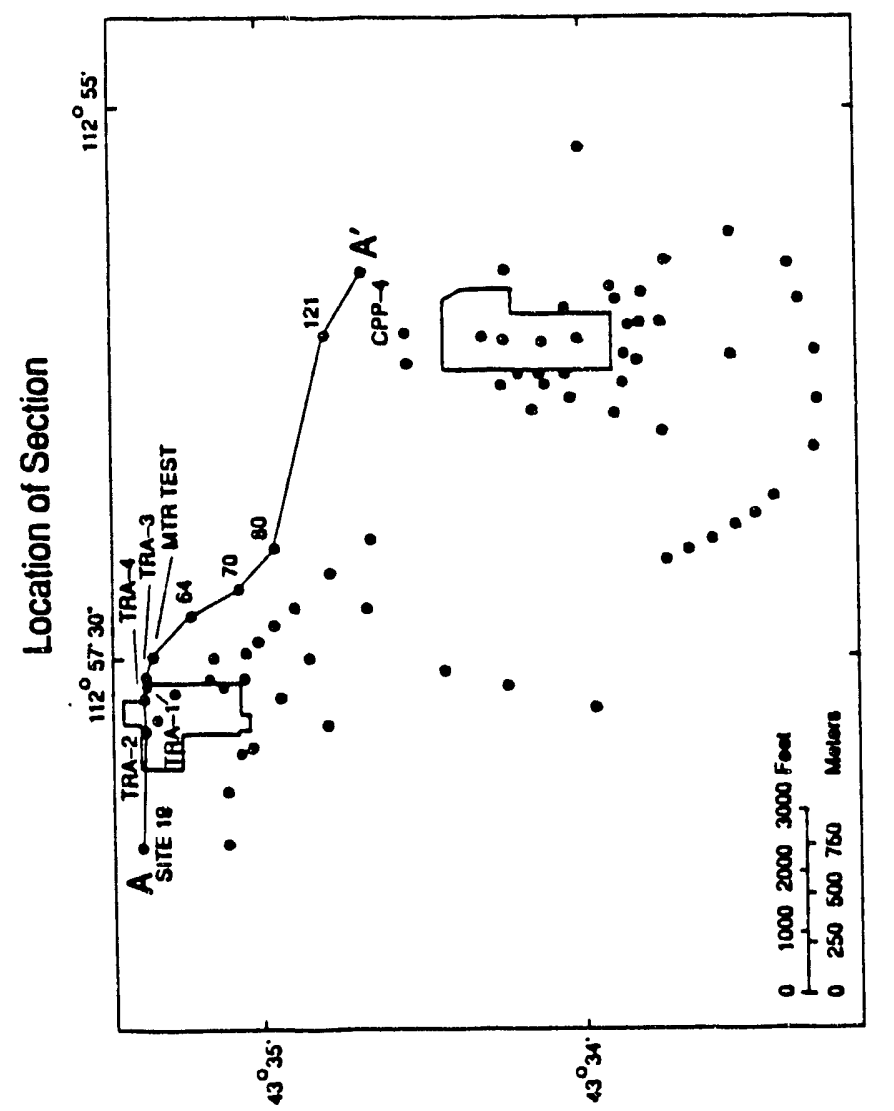

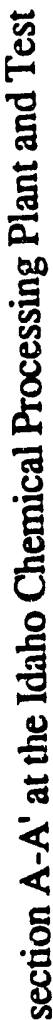

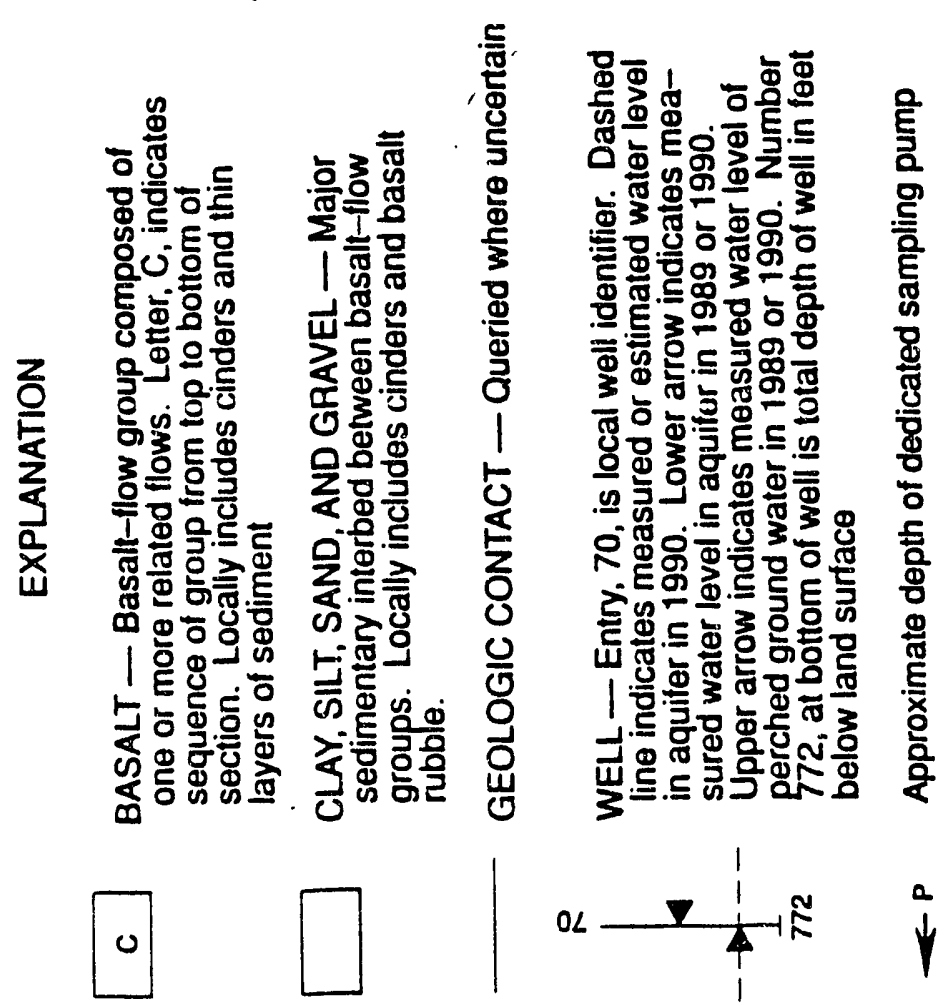




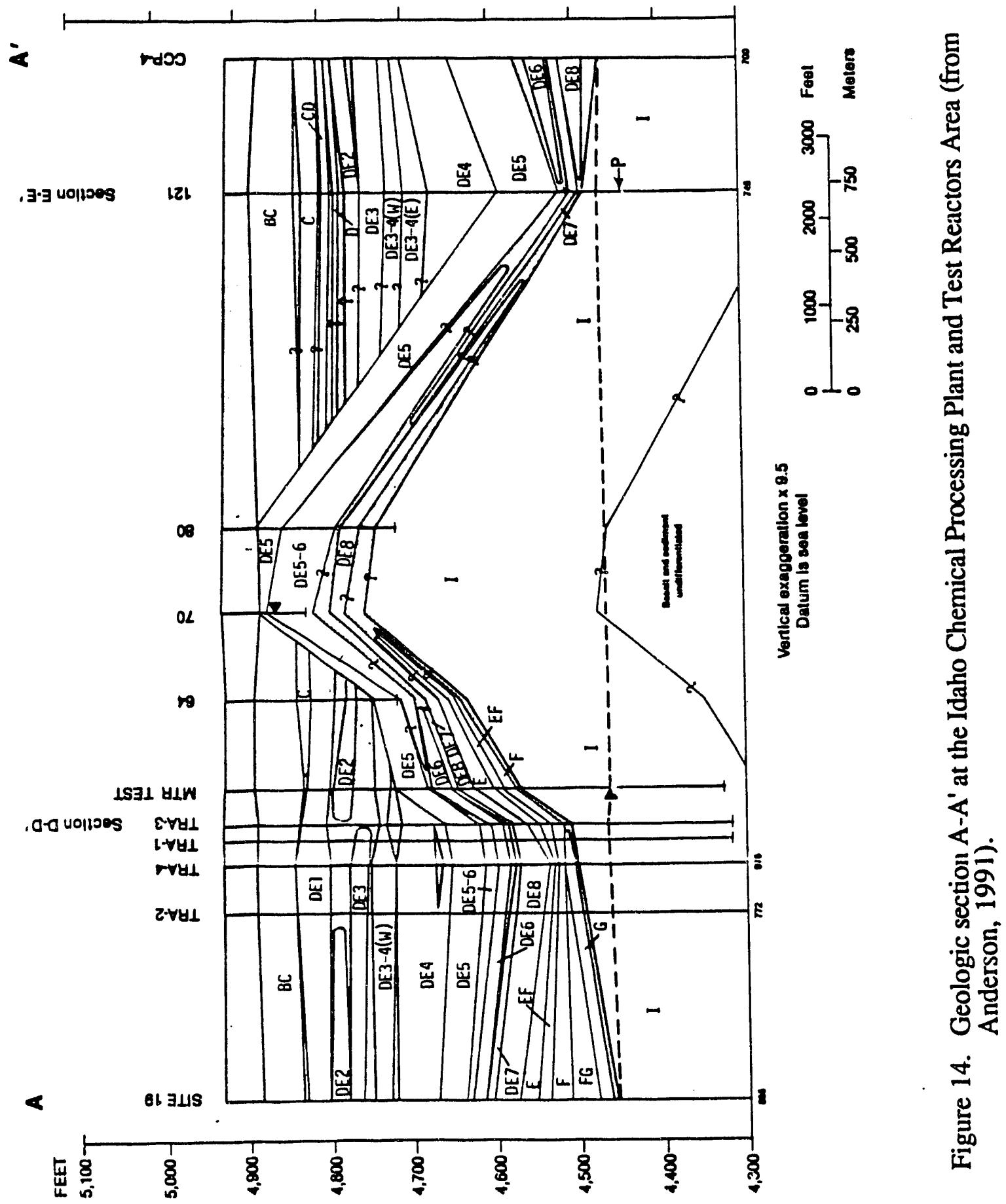




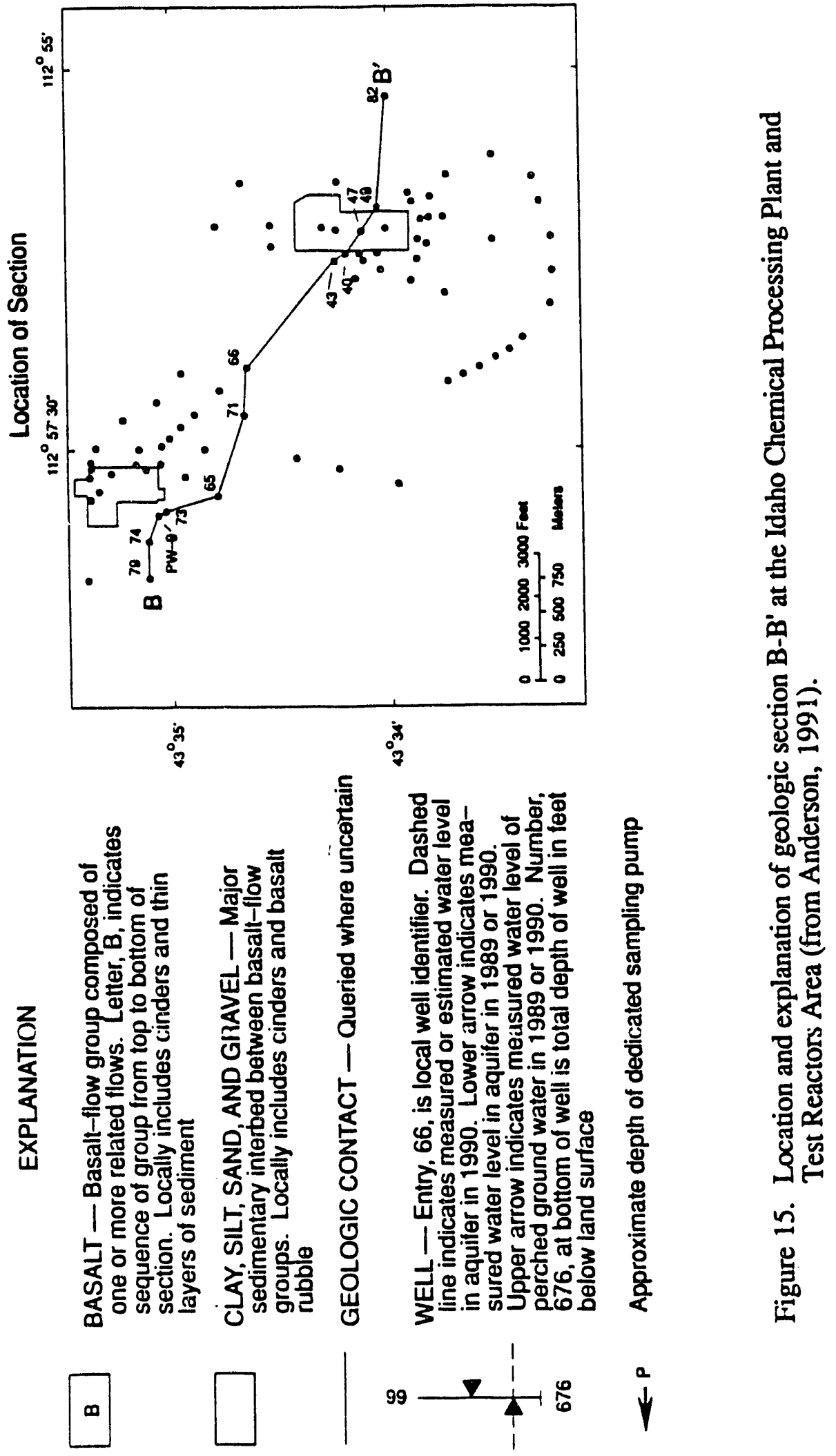




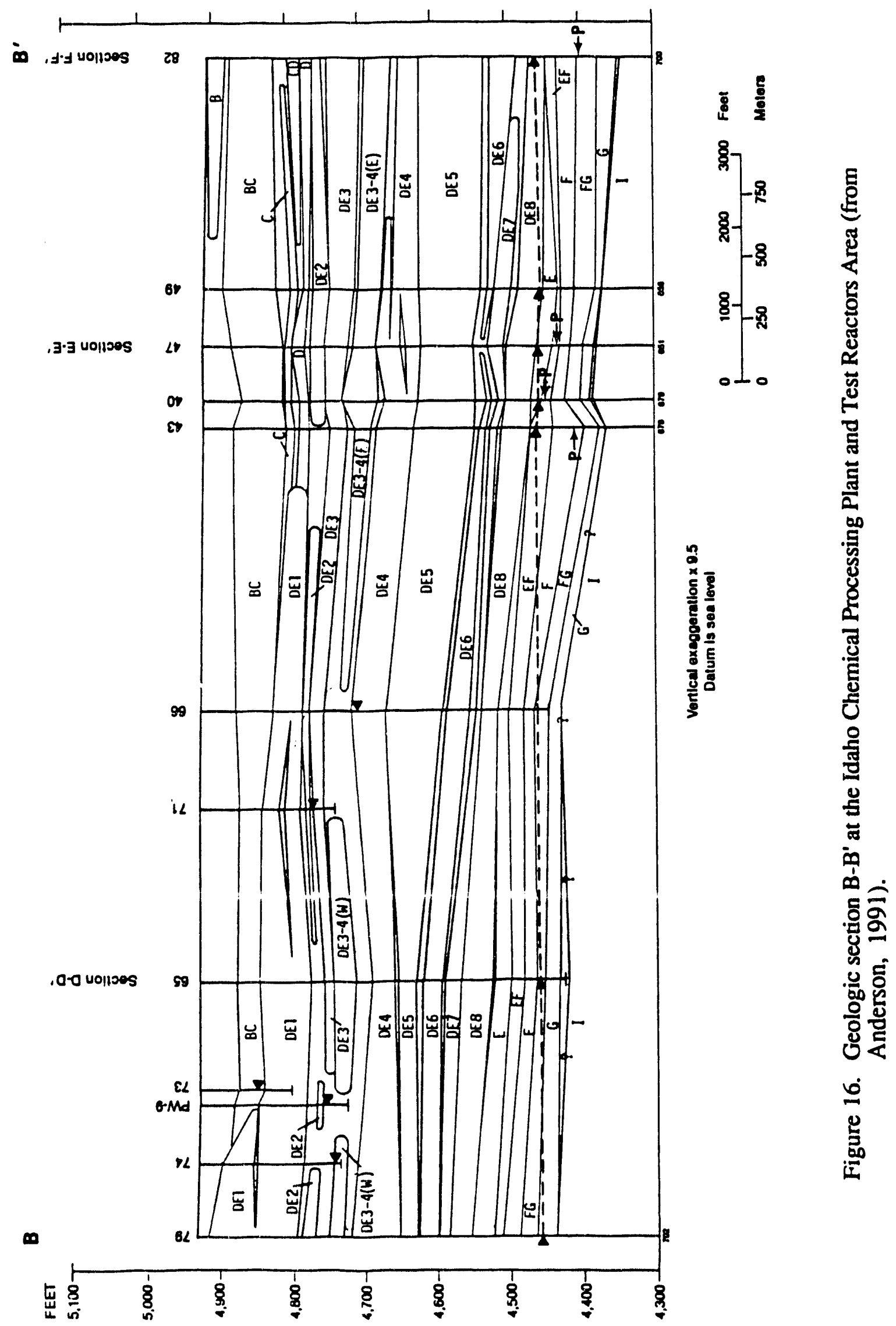




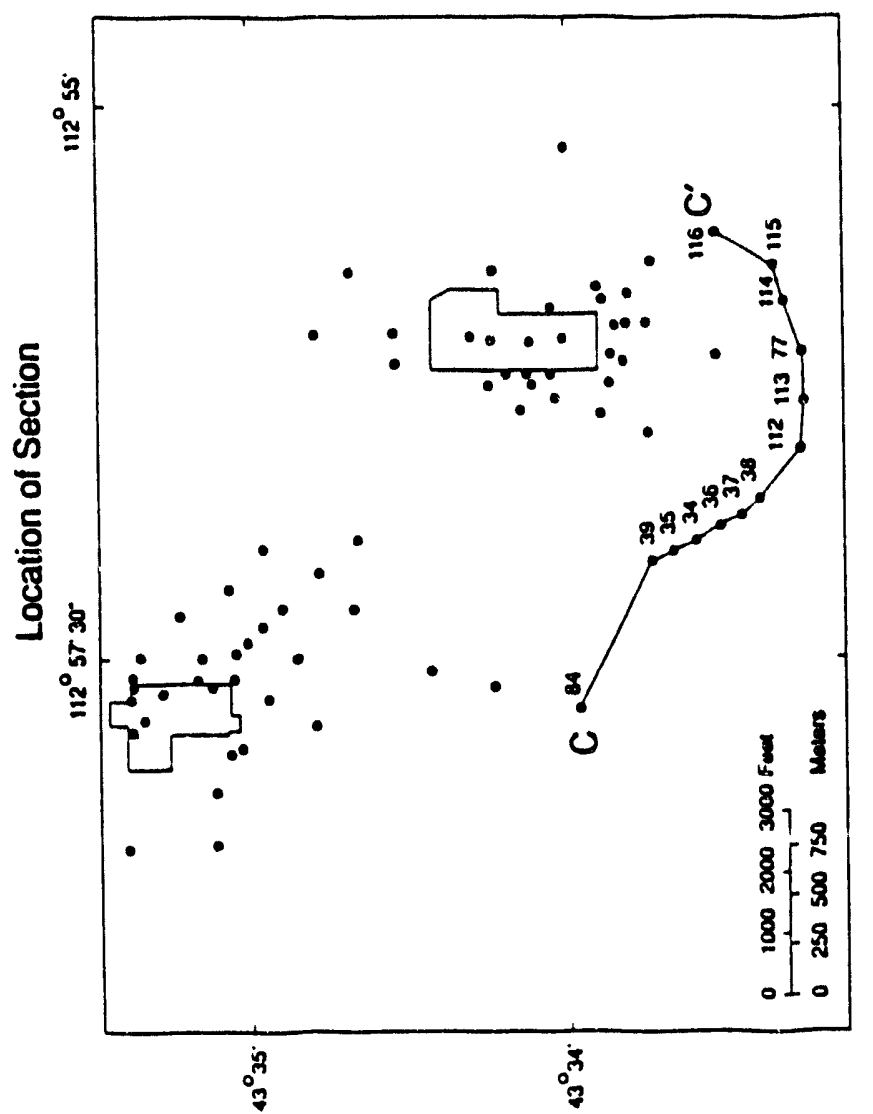

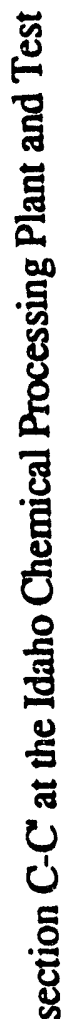
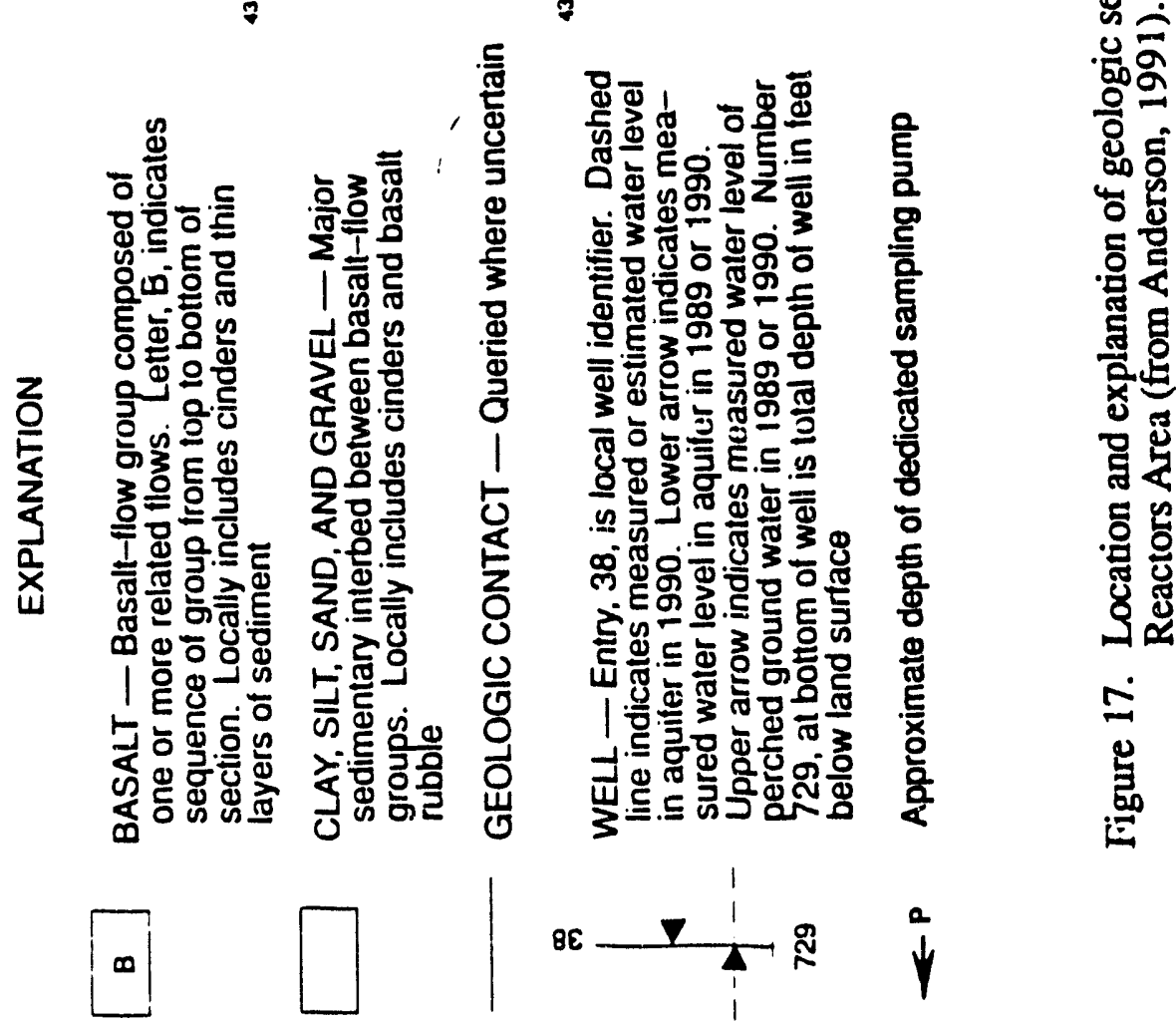


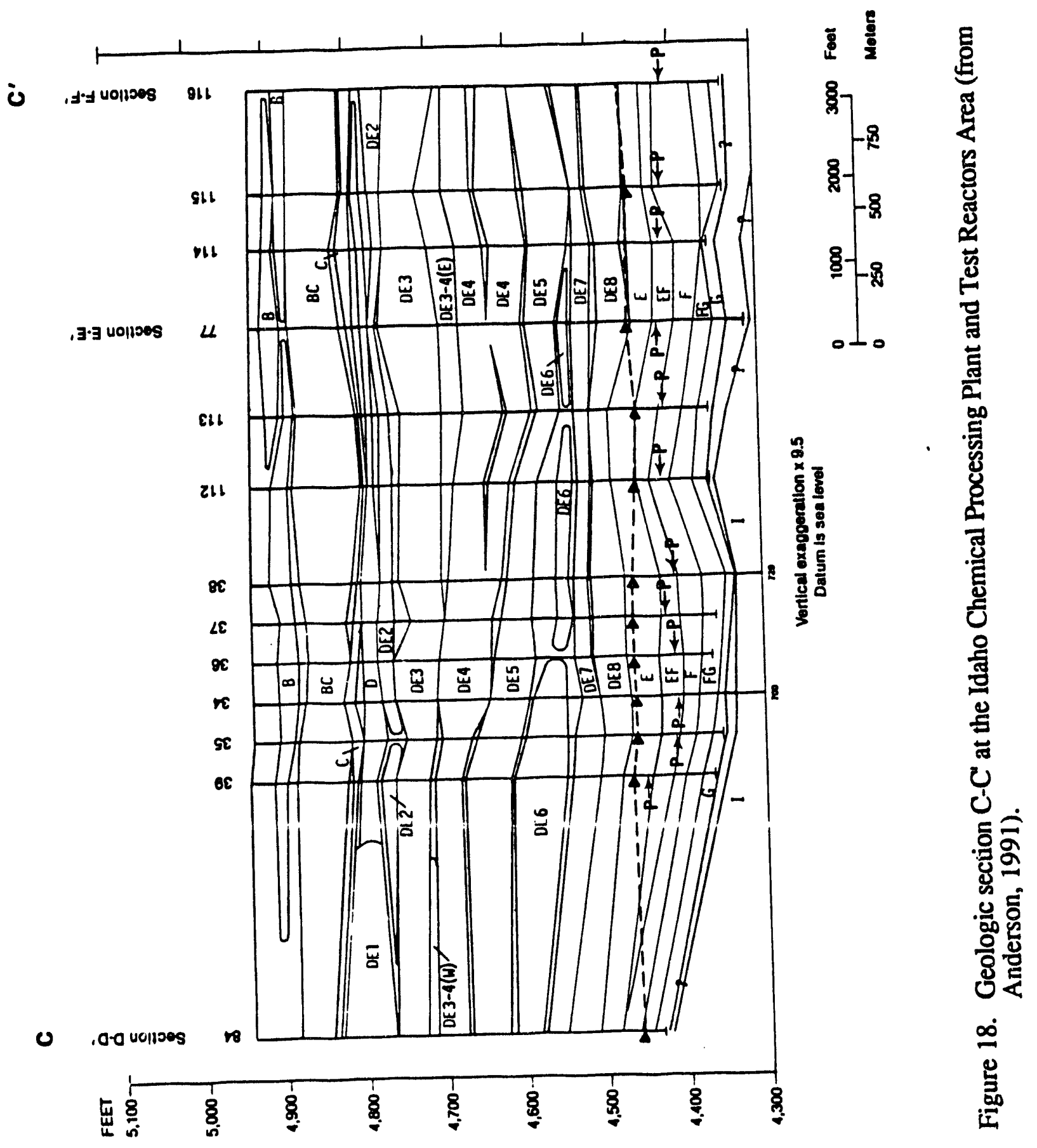




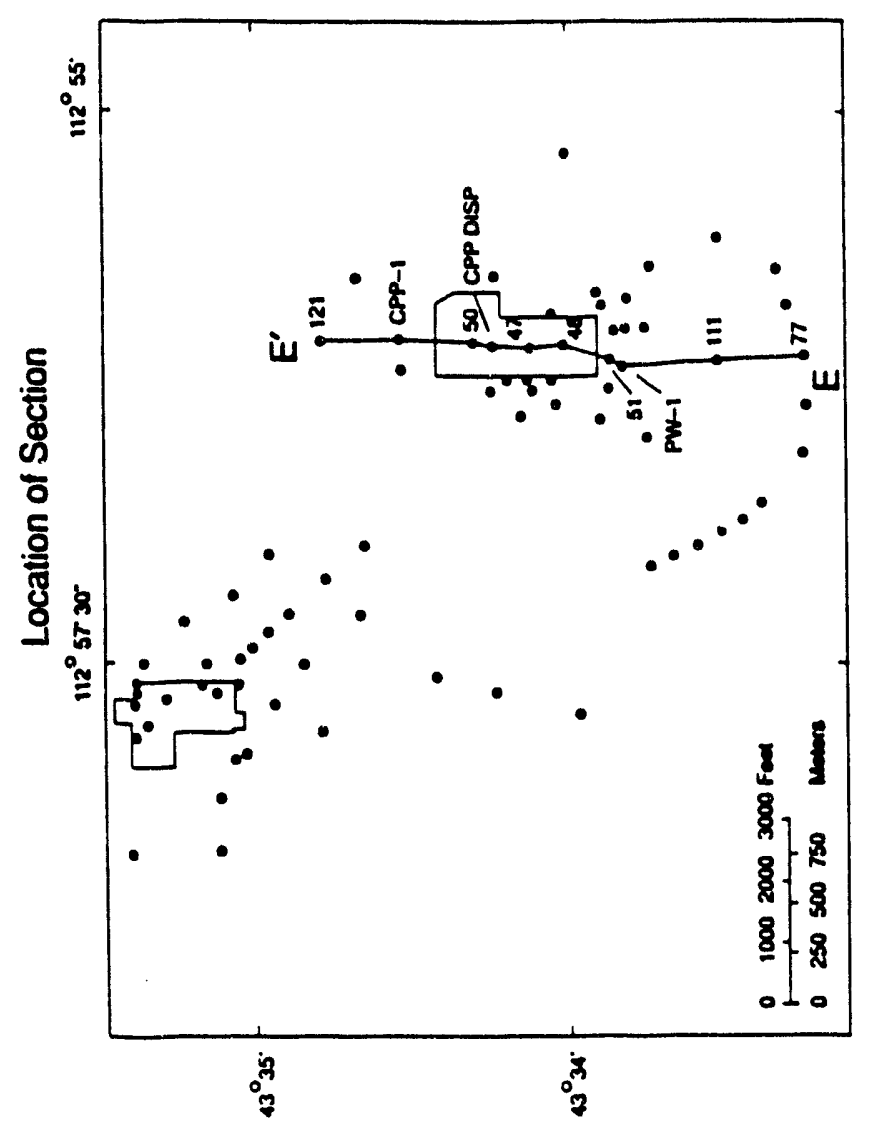

岁

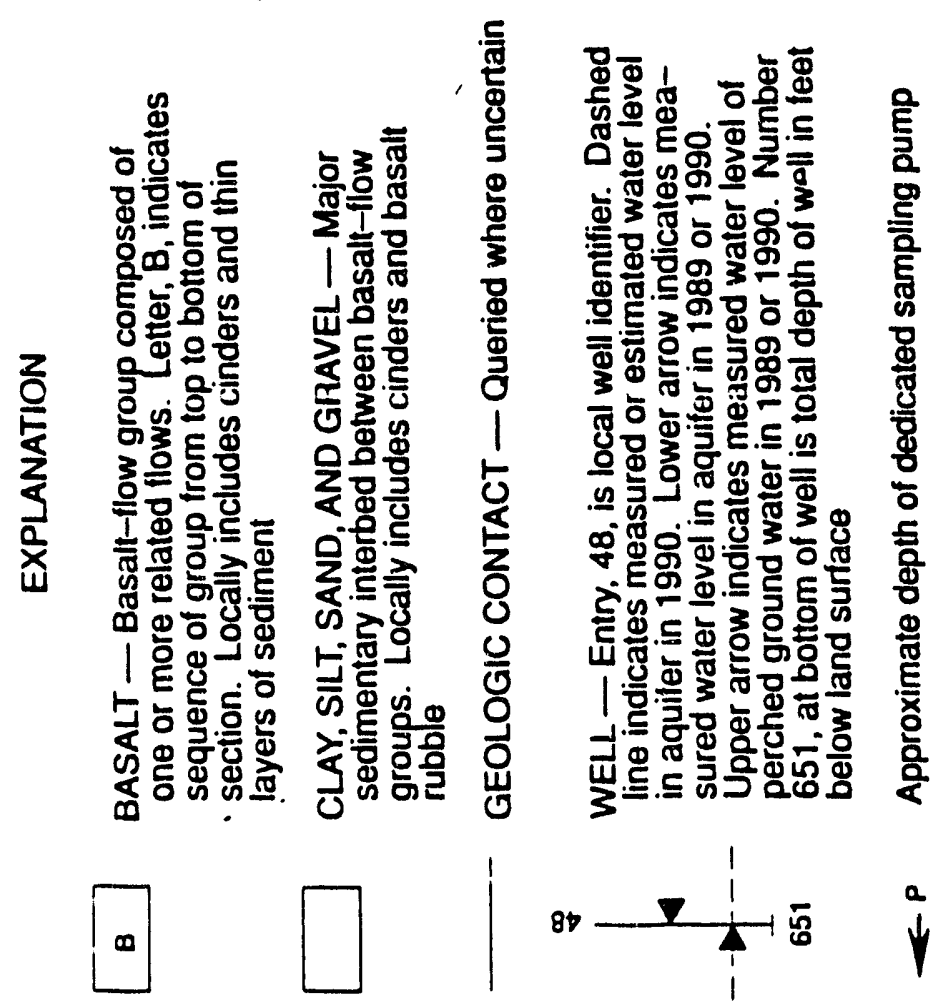

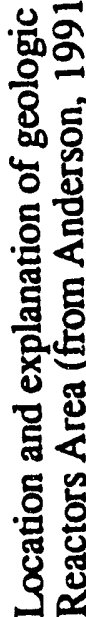

aे

岇

诖 


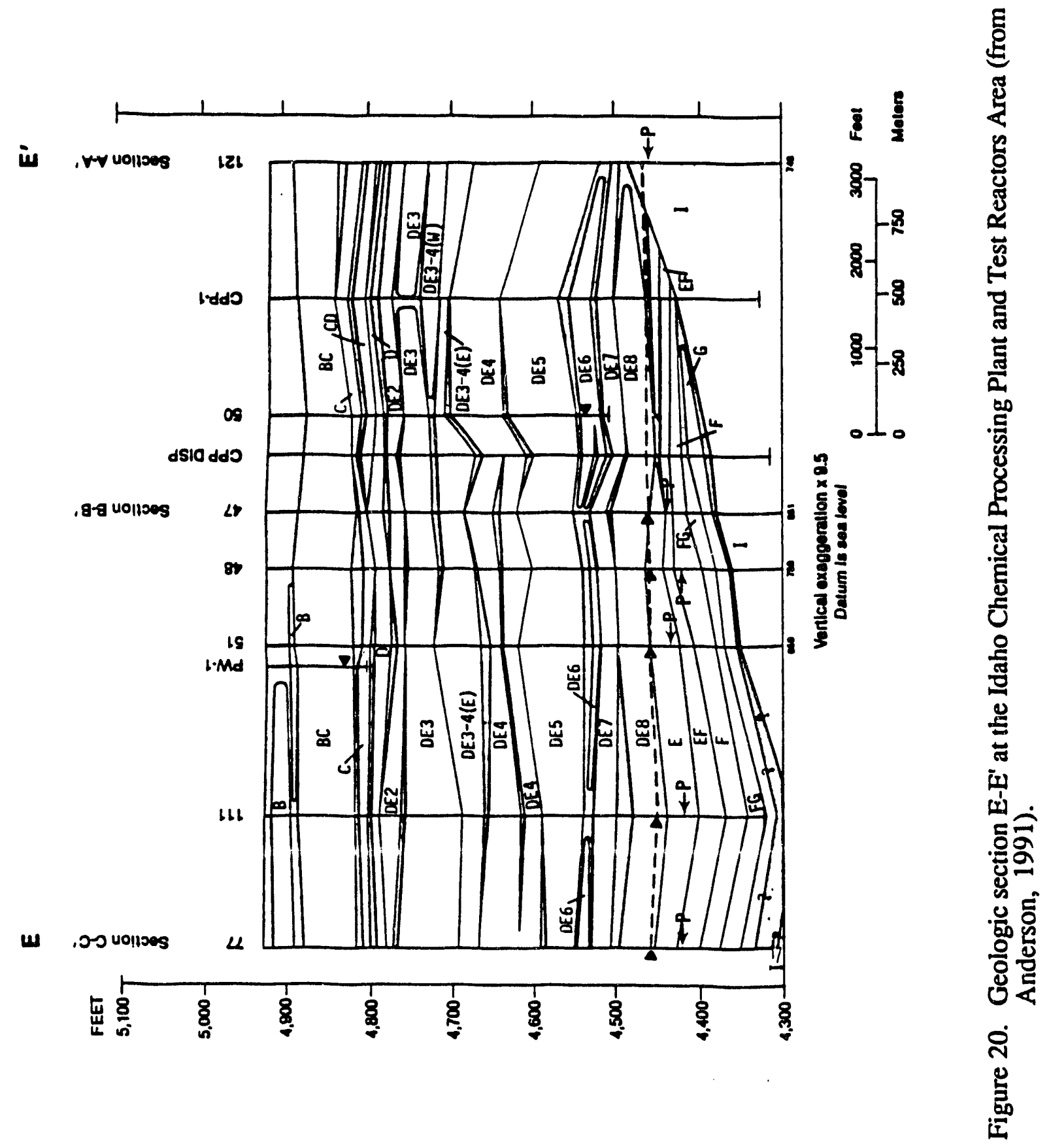


flow group contacts below the regional water table have been determined indirectly by the author from the geologic cross sections provided by Anderson (1991) (see Figures 13-20). Contact elevations were obtained in this manner for 25 of the 37 wells completed in the saturated zone in the vicinity of the ICPP.

Anderson's lithostratigraphic model implies that the stratigraphic relationships at the ICPP area are geologically complex, consisting of thin to thick, continuous to discontinuous flow groups, flow units and interbed horizons (Anderson, 1991, p. 15). Anderson states that the relationship between flow groups E, EF, F, FG, G, and $\mathrm{H}$ are "extremely complex" and may require additional drilling and basalt coring to identify geologic contacts more precisely.

Anderson's lithostratigraphic model has been used primarily to describe a possible depositional and tectonic history for the ICPP-TRA but does little to define directly the movement of ground water through the regional zone of saturation. Probable volcanic source vents have been defined for most basalt flow groups, and the structural geometries of composite flow groups have beén determined. These stratigraphic, depositional, tectonic, and structural interpretations are not intended to describe the occurrence of, or pathways for, ground water flow through the upper portion of the Snake River Plain aquifer. Anderson clearly states that additional field and laboratory evaluation of basalt and sediment characteristics will be necessary to describe accurately the movement of contaminated ground water through the regional aquifer system. 


\title{
CHAPTER 5
}

\section{HYDROSTRATIGRAPHIC CORRELATION OF POST-1960 WELLS}

\author{
Introduction
}

This chapter presents an evaluation to determine if distinct hydrostratigraphic zones are recognizable in, and correlatable between, new wellbores drilled since 1960 using the correlation methods described by Jones (1961). Interwell correlations are used to test the applicability and predictive power of the hole-diameter-based, hydrostratigraphic conceptual model within a new monitoring well array proximal to the original model domain. Jones's conceptual model suggests that flow top aquifers should pinch out to the south and southeast and remain laterally continuous to the southwest of the ICPP.

Eleven additional monitoring wells have been completed in the upper portion of the Snake River Plain aquifer at the ICPP since Jones's hydrostratigraphic correlation model was published by the USGS in 1961 (see Table 2). The hydrostratigraphic correlation methods used by Jones (1961) are applied by the author to selected post-1960, ICPP monitoring wells that satisfy the following criteria:

a. Wells must not be cased or screened below the regional water table, and

b. Lithologic, caliper and natural-gamma logs must exist for the uncäsed portions of there wells.

Wells $77,111,112,113,114,115$ and 116 each meet these requirements. Completion information for these wells is provided in Table 2 with relative well locations shown in Figure 21. All of the 100-series wells were drilled by air rotary methods (U.S. DOE, 1990a).

Lithologic information available for the post-1960 wells is generally fair to pcor. Little faith can be placed in the subsurface lithologic descriptions given in drillers' logs, 


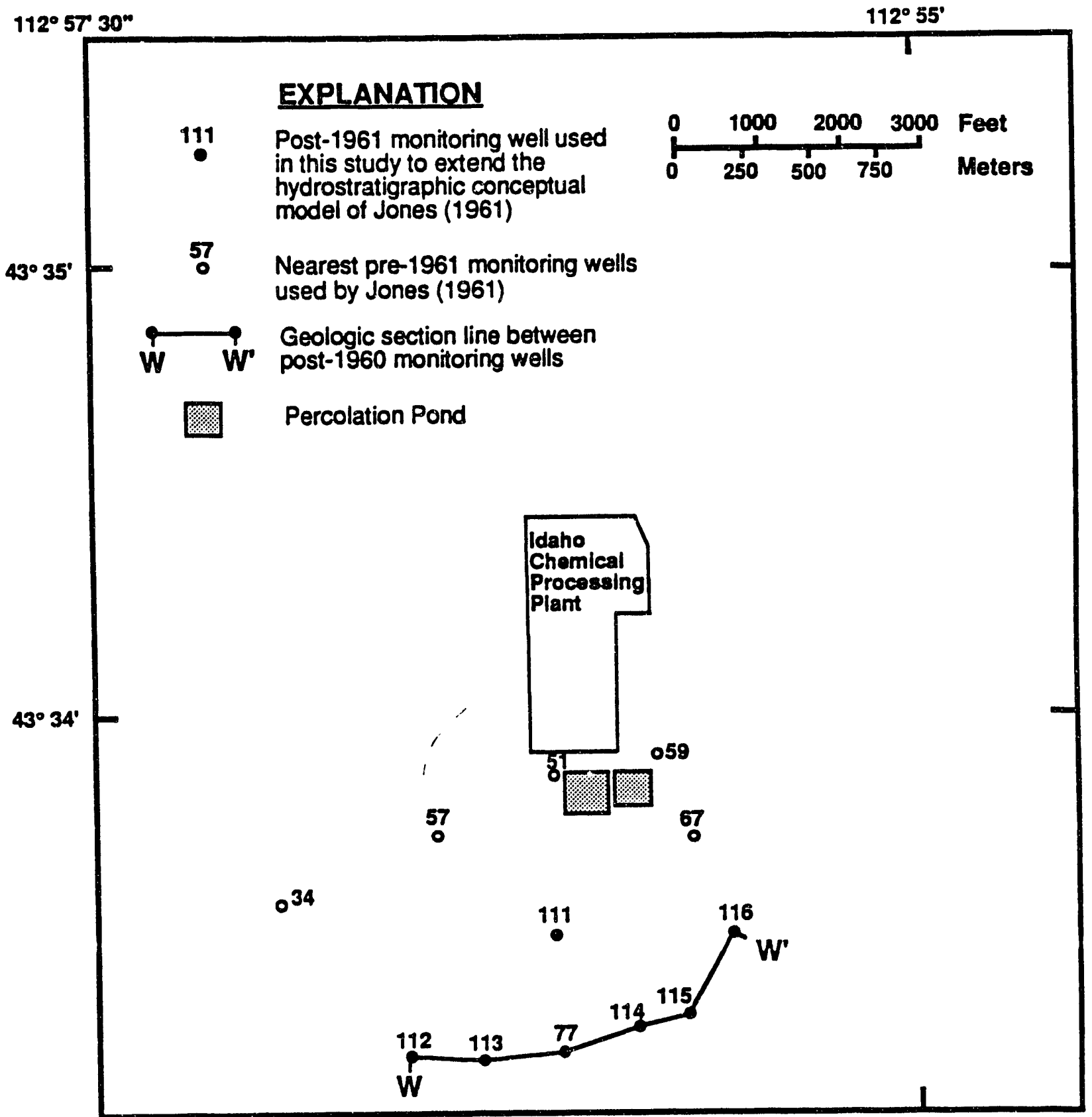

Figure 21. Location map of ground water monitoring wells used to test the hydrostratigraphic correlation methods of Jones (1961) (After Anderson, 1991). 
especially for the 100-series wells (see Appendix 1, p. 110-112). For example, close inspection of the drillers' information for wells 112 and 114 shows that the stratigraphy is coincidentally identical; this suggests that lithologic and depth data for 114 may have been copied directly from the log of 112 . The basalt stratigraphy below the water table in wells $111,113,114$, and 116 is completely undifferentiated, whereas the driller's log for 115 mentions only one lithologic change over the 140 -foot saturated section.

\section{Correlation Between Post-1960 Wells}

Representative caliper and natural-gamma logs for well 77 and the 100 -series wells under consideration in this evaluation are presented in Appendix 1, pages 113-119. Probable aquifers have been identified by the author for each well based on an interpretive evaluation of these data using the methods of Jones (1961). The depth, altitude, and thickness of the probable aquifers present in each well are summarized in Table 6. An interpretive hydrostratigraphic cross-section drawn through these new monitoring wells is shown in Figure 22.

Well 77 is located at the geographic center of the post- 1960 monitoring well network and is the last of the ICPP monitoring wells to be drilled using cable tool methods. The effect of the repeated impact of the drill bit and slapping of the cable against the borehole wall has resulted in large-diameter hole enlargements in zones of fractured basalt or unconsolidated sediments. Three or four probable water-bearing zones are indicated by the caliper log in this well using the aquifer identification methods described in Chapter 4.

Wells 111 and 114 are located approximately 1400 and 1000 feet north and east of well 77 , respectively (see Figure 21 ). The relatively smooth, constant-diameter borehole intervals in these wells are in marked contrast to the highly varied borehole geometry observed in well 77 . Hole diameter variations of more than 0.5 inches do not exist below the water table in wells 111 and 114. 


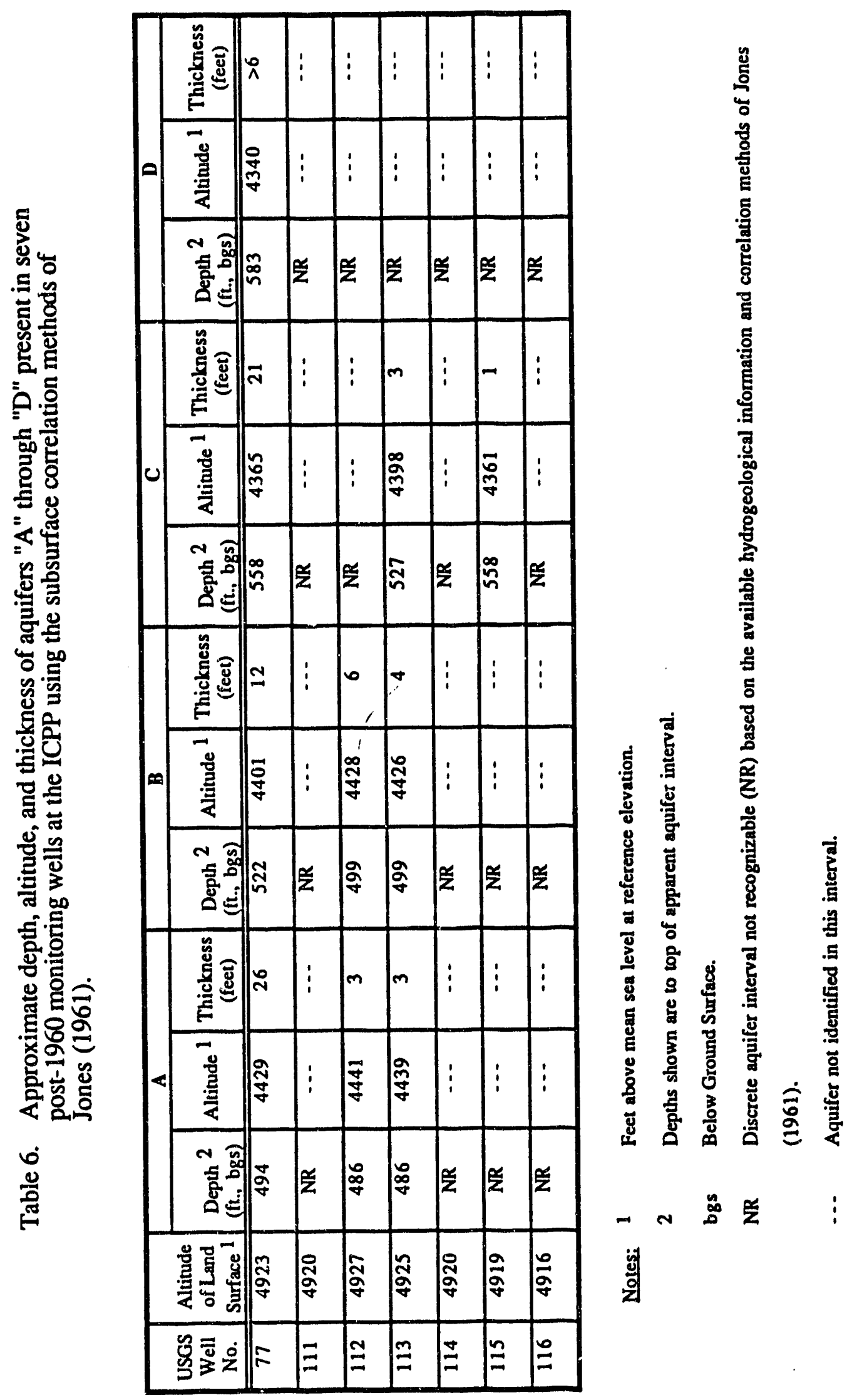




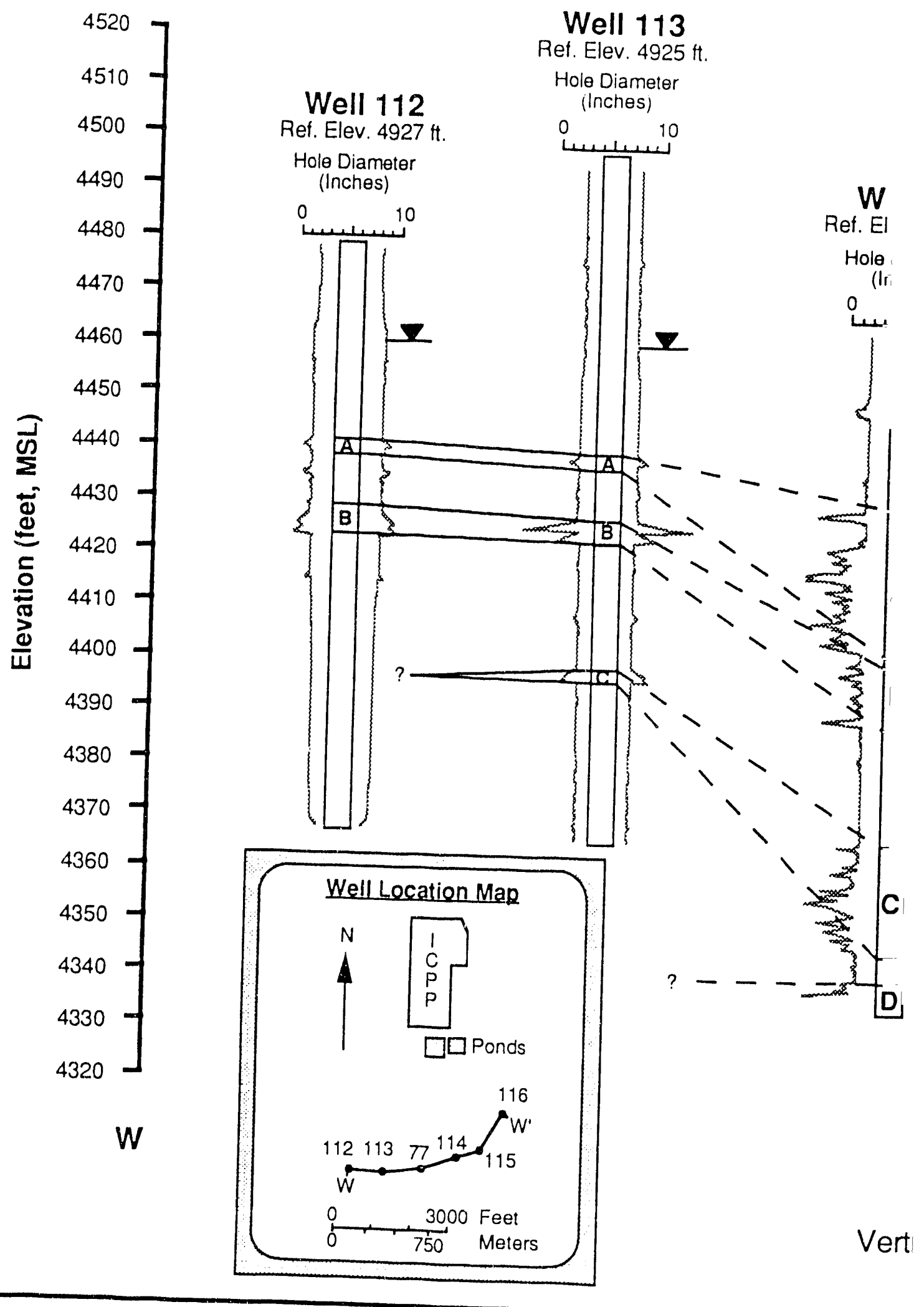

Figure 22. Interpretive hydrogeologic cross sectio ICPP area based on the hydrostratigrap 


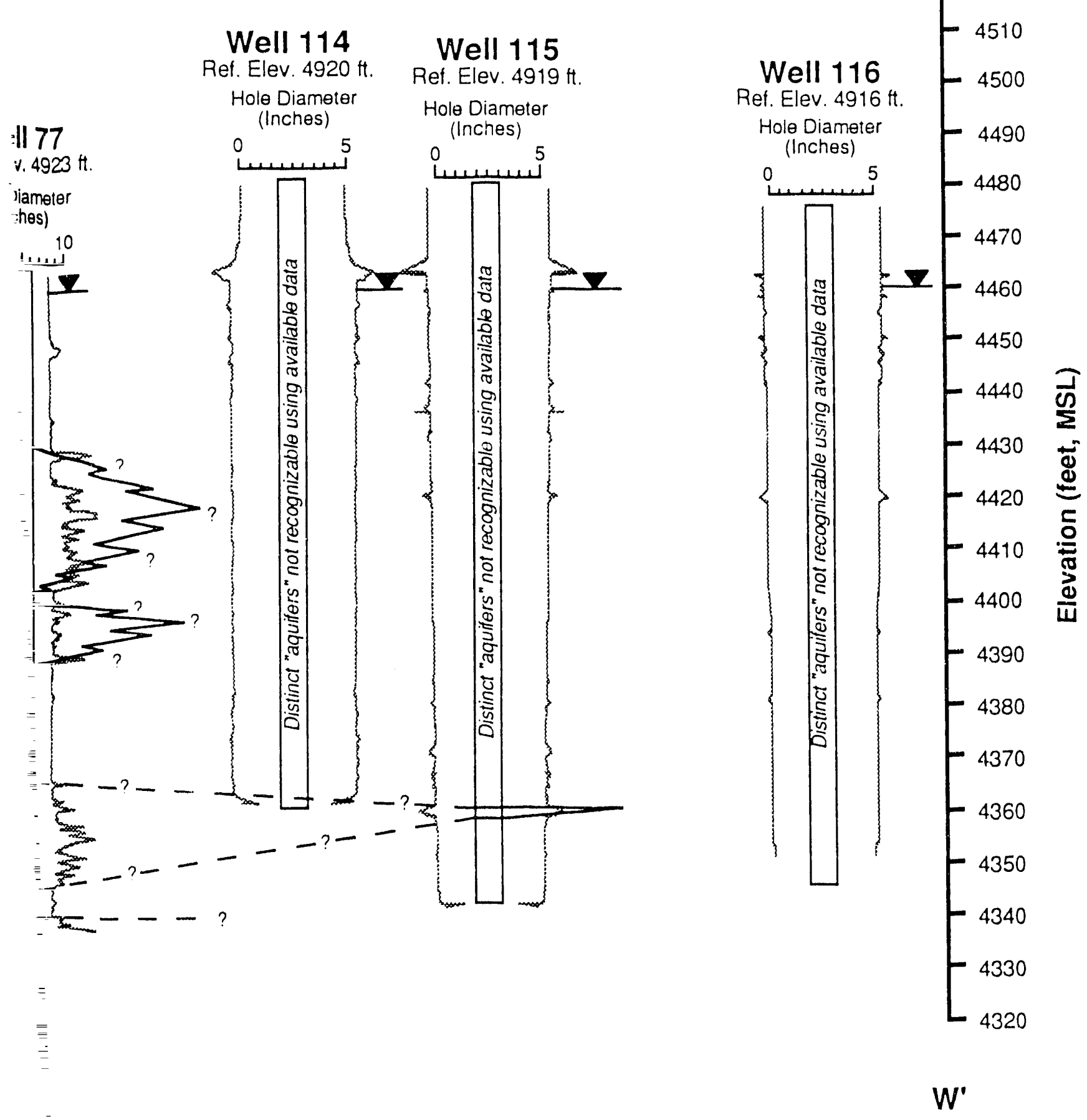

Exaggeration: 20x

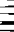

Note: Water levels shown are approximate

W.W' through selected post-1961 monitoring wells at the

$=$ ic correlation methods of Jones (1961). 
Relatively invariant hole diameter conditions are also observed in caliper logs from wells 115 and 116. Two or three separate one-half- to one-inch breakouts occur in the upper saturated section of both wells and in the lower portion of 115 . These caliper anomalies may represent isolated vesicular zones or vertical fractures intersected within massive flow interiors. However, insufficient similitude exists between the lithologic, natural-gamma, or hole-diameter data to allow for this author to confidently extrapolate these zones between wells. A one-inch enlargement at a depth of approximately 560 feet (4359 ft., MSL) in well 115 correlates with a fine-grained, sedimentary layer noted both in the drillers' and natural-gamma logs. This well defined interbed is not expected to be a significant water-producing zone due to the low hydraulic conductivity of the sediments compared to highly fractured or vesicular basalts.

Three pronounced zones of borehole enlargement exist in well 113 at depths of 486 to 530 feet (4439 to $4395 \mathrm{ft}$., MSL). These intervals are correlated with zones showing similar caliper log anomalies in well 112. However, positive correlation of these hydrostratigraphic intervals between wells 77 and 113 is uncertain due to the radically different drilling methods used for well construction.

Correlations between the post- 1960 wells suggest that a series of separate, probable water-producing zones may exist in the upper 60 feet of saturated basalts west of well 77 (Figure 22). These zones appear to pinch out to the north and east of well 77. A twentyfoot thick probable water-producing zone (Aquifer "C") also exists lower portion of well 77. The lateral extent of this highly fractured interval is uncertain due to the different drilling methods used in the surrounding wells.

\section{Hydrostratigraphic Correlation Between Pre-and Post-1960 Wells}

Water-bearing zone "A"+"B" in wells 112 and 113 does not have recognizable caliper log equivalents in wells 34 or 57 ; the closest pre- 1960 monitoring wells with 
hydrostratigraphic control (see Figures 21). Representative caliper and natural-gamma logs for the proximal pre-1960 wells under consideration in this evaluation are presented in Appendix 1, pages 120-124. A zone of pronounced caliper deflection at a depth of 480 feet in well 51 may correlate to the "A"+"B" zone in wells 112 and 113, although this interval was not recognized as a significant "aquifer" by Jones (1961). However, the lack of occurrence of this breakout in well 111 suggests that the 480 -foot interval noted in well 51 is not laterally continuous to the south and southwest and therefore does not extend to wells 77,112 , and 113.

Caliper log correlations between wells 114 through 116 and the nearest pre-1960 monitoring wells should not be attempted given the lack of hole diameter variation shown in these 100-series wells. Well 67 shows large borehole diameter enlargements within and below Jones's aquifer "A" at depths of 490 to 515 feet (Appendix 1, p. 123). This interval does not have a hydrostratigraphic equivalent in wells 114 through 116 based on available caliper and/or lithologic logs. Furthermore, there is insufficient geometric similitude to match confidently the previously identified hydrostratigraphic zones in wells 51 and 59 (Appendix 1, p. 122 and 124) to the minute caliper deflections observed in wells 114 through 116 (Appendix 1, p. 117-119).

The areally extensive sedimentary interbed identified by Jones (1961) in most of the pre-1960 wells is also identifiable in the more recently drilled wells, although such correlations generally are not directly dependent on the use of caliper log data. Drillers' logs combined with natural-gamma logs are the most useful indicators of this interbed horizon, as discussed and evaluated by Anderson (1991). This interbed occurs at a depth of 582 feet ( $4341 \mathrm{ft}$, MSL) in well 77 and may be correlated between wells 77 and 112 as demonstrated by Anderson (1991) (see Figures 17-18). However, this unit is not penetrated by wells $113,114,115$, or 116 ; but is believed to exist below the final completion depths for these wells (Anderson, 1991). 
Zones of significant borehole enlargement observed in well 77 and the 100 -series wells are not recognized by this author as representing direct hydrostratigraphic equivalents of aquifers "A" through "E" identified by Jones (1961). This observation is attributed to a combination of the following conditions:

a. The "flow top aquifers" interpreted by Jones (1961) are laterally discontinuous and may contain textural changes between the locations of the pre- and post-1960 monitoring wells.

b. The geometry of borehole enlargements within a given "flow top aquifer" may be significantly different between adjacent wells due to the relatively non-destructive drilling methods (i.e., air rotary) used in the 100 -series wells versus the cable tool drilling used in the pre-1960 wells

c. Positive identification and correlation of distinct hydrostratigraphic intervals is extremely difficult because of insufficient hydrologic data.

Jones's hydrostratigraphic model envisioned a relatively flat-lying aquifer sequence devoid of any major structural discontinuities within the ICPP area. Jones described aquifer discontinuities only as the result of lateral terminations and/or thinning of "fractured flowstops". The comparative effects of different drilling methods may only be inferred in this study because side-by-side boreholes drilled both by air rotary and cable tool methods do not currently exist for the saturated section of Snake River Basalts beneath the ICPP.

\section{Conclusions}

Caliper, natural-gamma, and lithologic (drillers') logs for wells 77, 111, 112, 113, 114,115 and 116 define relatively few laterally continuous hydrostratigraphic zones within in the 120-foot plus thick saturated basalt sequence penetrated by these wells. Probable aquifer intervals are identifiable in, and correlatable between limited sections of wells 112 , 113 , and 77 , located to the south-southwest of the ICPP. Based on the correlation 
methods described by Jones (1961), laterally continuous aquifers do not appear to exist to the south-southeast of the facility in the area of wells $111,114,115$ and 116. These observations suggest that:

a. Hydrologically separate, laterally continuous, aquifers rarely exist within the saturated basalts penetrated by most of the post-1960 monitoring wells, or

b. The hydrostratigraphic correlation methods of Jones (1961) are insufficient for determining the detailed, spatial distribution of distinct basalt aquifers both within and between many of the post-1960 monitoring wells.

Conclusion " $a$ " is highly unlikely because these wells are known to be highly productive, based on small-scale aquifer tests conducted during ground water sampling events (Ackerman, 1991). The caliper log correlation methods used by Jones (1961) and by the author in this study therefore are telieved to be insufficient for identifying and correlating probable water-bearing zones, especially between wells completed with different drilling methods, such as cable tool versus air rotary or air percussion. Additional downhole evaluations including down-hole television, up-dated geophysical characterization, (i.e, fully calibrated density and porosity logs, and heat-pulse flow meter tests, or equivalent), as well as depth-specific cross-hole hydraulic testing, will be helpful to evaluate quantitatively these conclusions. 


\title{
CHAPTER 6
}

\section{COMPARISON OF LITHOSTRATIGRAPHIC AND HYDROSTRATIGRAPHIC INTERVALS}

\author{
Introduction
}

This portion of the study compares the spatial relationship between the "flow top aquifers" identified by Jones (1961) and the lithostratigraphic contacts between basalt flow groups identified by Anderson (1991) in selected ICPP monitoring wells. This qualitative comparison is conducted to test the hypothesis that highly fractured or rubbly water-bearing zones, which are identified as zones of significant borehole enlargement, are correlatable with basalt flow contacts or interflow zones within the upper portion of the Snake River Plain aquifer beneath the ICPP area.

\section{Method of Comparison}

ICPP monitoring wells used in this exercise have been selected using the following criteria.

a. Wells must be drilled using cable tool methods (see Table 2) and,

b. Wells must be directly intersected by geologic cross sections B-B', C-C', and E-E' of Anderson (1991).

The cable tool drilling criterion is necessary to standardize qualitatively the effects of drilling activities within the open borehole intervals under consideration. Caliper logs from these wells are considered to be equally representative of the open borehole geometries at depth and therefore are suitable for the comparative identification of aquifer intervals by the methods of Jones (1961). Variable bit penetration effects, caused by different drilling- 
styles and technical abilities of the various drillers involved, are assumed to be insignificant for the six well used in this study.

Criterion " $b$ " identifies wells for which flow group-specific contact elevations are directly measurable from geologic cross sections drawn through the study area (see Figures 13-20, after Anderson, 1991). Precise contact elevations for individual flow groups are otherwise unavailable from the USGS because of the interpretive nature of these data (Anderson, personal communication; Mann, personal communication).

Wells $43,47,48,49,51$, and 77 each satisfy these requirements. All of these wells are described hydrostratigraphically by Jones (1961), with the exception of well 77; the hydrostratigraphy of well 77 is characterized qualitatively in Chapter 5 of this report (also see Appendix 1, p. 113). Well 40 is not included in this analysis because it is fully lined with 4-inch steel casing below the regional water table.

Identified lithostratigraphic contacts within the six selected monitoring weus are graphically transposed from the geologic cross sections of Anderson (1991) to the respective natural-gamma logs of Bartholomay (1990). The accuracy of correlating these geologic contacts back to the geophysical logs from which they are derived is approximately $+/-2$ feet given the vertical scale of Figures 13-20 and the subjectivity of certain contact "picks" (Anderson, personal communication). Hydrostratigraphic intervals (i.e., aquifers), as delineated numerically by Jones (1961), are transposed from the Table 5 aquifer summary to the respective caliper logs of Bartholomay (1990). Compiled and enlarged versions of these data for the six monitoring wells under consideration in this analysis are presented in Appendix 1, pages 113, 122, and 125 through 128. The lithostratigraphic and hydrostratigraphic identifiers used by Anderson and Jones to categorize the saturated basalt sequence are also shown graphically for each well in Appendix 1. A north-south trending, schematic, geologic cross section, drawn through wells $43,47,48,51$, and 77 , is shown in Figure 23 and graphically compares these lithostratigraphic and hydrostratigraphic interpretations with depth. 


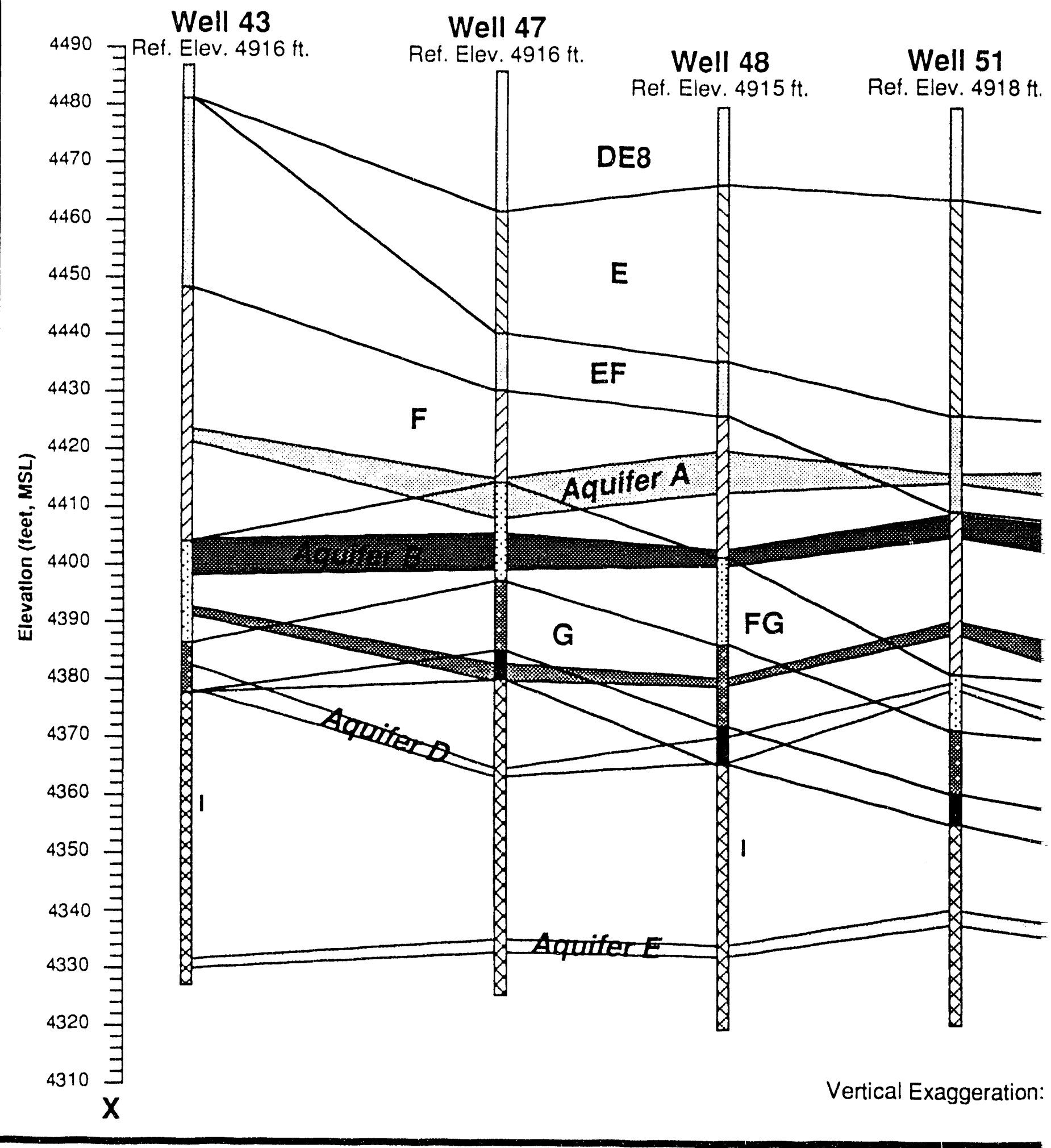

Figure 23. Geologic cross section $X-X^{\prime}$ through interpretations by Jones (1961) with 


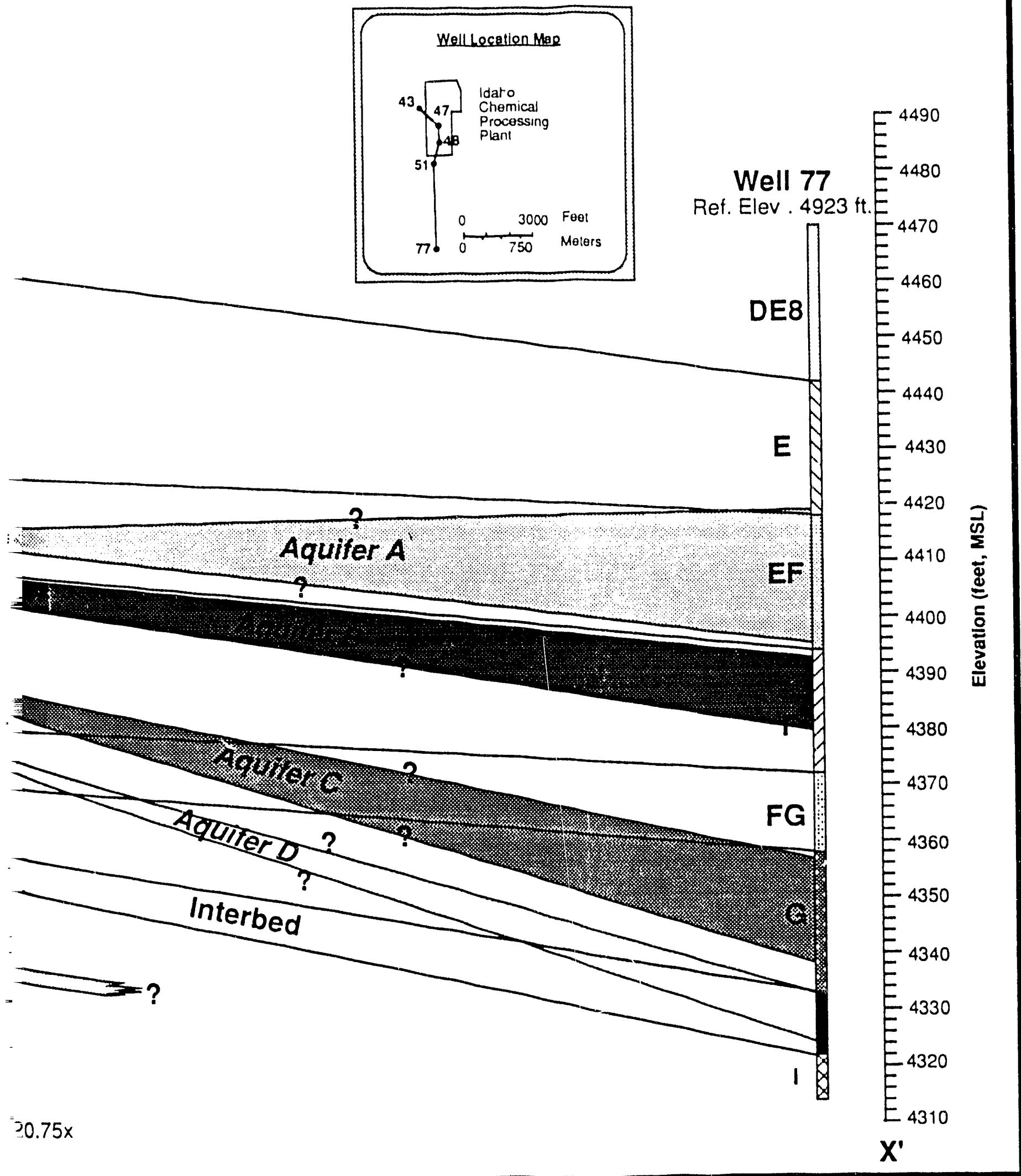

he ICPP area comparing aquifer jasalt stratigraphy defined by Anderson (1991). 


\section{Discussion of Results}

A summary of the comparative spatial relationships between hydrostratigraphic and lithostratigraphic intervals for the six selected monitoring wells is snown in Table 7. Aquifers "A" through "D" (after Jones, 1961) are described by the lithostratigraphic basalt flow group (after Anderson, 1991) in which they are located. Where possible, each aquifer is ranked qualitatively for the degree to which its vertical position correlates with the nearest, interpreted basalt flow group contact. Aquifer " $E$ " is everywhere positioned within the massive, currently undifferentiated basalt flow units of flow group I and therefore is not considered in this correlation analysis. Aquifers falling within basalt flow groups $\mathrm{E}, \mathrm{EF}$, and I are not included in the overall ranking distribution because these flow groups are known to be comprised of more than one, presently undifferentiated flow unit (Anderson, 1991). Rankings for the remaining 21 aquifer identifications are based on the understanding that productive aquifers within the Snake River Basalt occur typically within well-defined interflow zones situated between adjacent basalt flows (Lindholm and Vaccaro, 1988; see Figure 5) and that flow groups F, FG, and G are each comprised of only one flow unit (Anderson, 1991, p. 21). The criteria used for qualitatively ranking each açuifer correlation are as follows:

Ranking Correlative Location of Aquifer

Poor Entirely within a single flow group with aquifer boundaries $>2$ feet from flow group contacts

Moderate At or within 2 feet of flow group colitact and falling within bottom or upper $1 / 4$ of nearest flow group

Excellent Completely straddling a single flow group contact

Interbed Within sedimentary interbed

Intervals of significant borehoie cnlargement, which are assumed to represent "aquifers" by Jones (1961), occur both within fluw groups and at the interpreted flow 


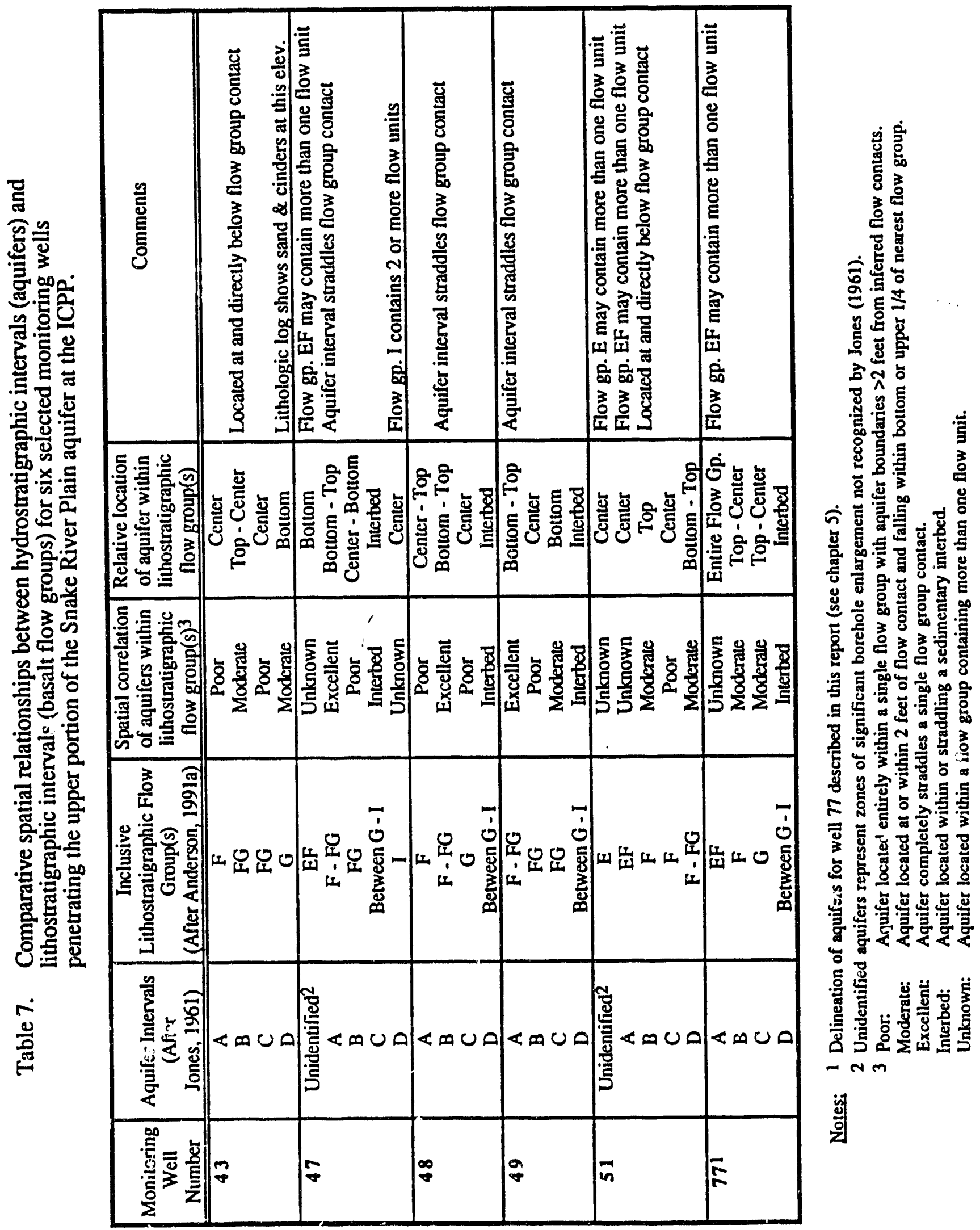


group contacts within the six wells under consideration. The small-scale spatial relationships used for assigning correlation rankings within each well are shown on pages 122 and 125 through 128 of Appendix 1. The ranking distribution for 21 of the aquifer intervals identified by Jones (1961) in wells $43,47,48,49,51$, and well 77 is provided in Figure 24. This figure shows that only 14 percent of the aquifers show Excellent correlation with inferred flow group contacts whereas 33 percent of the aquifers show Poor correlation. About 67 percent of the aquifer intervals, including those satisfying the Excellent, Moderate, and Interbed ranking criteria, are situated within two-feet of an inferred flow group contact. The two-foot inclusion interval is used to account for the potential inaccuracies of transferring the inferred flow group contacts from Anderson's geologic cross sections to their respective natural-gamma logs. These data indicate that the stratigraphic position of flow group contacts alone does not strictly control the occurrence of borehole enlargements and related (inferred?) water-producing zones in these six wells.

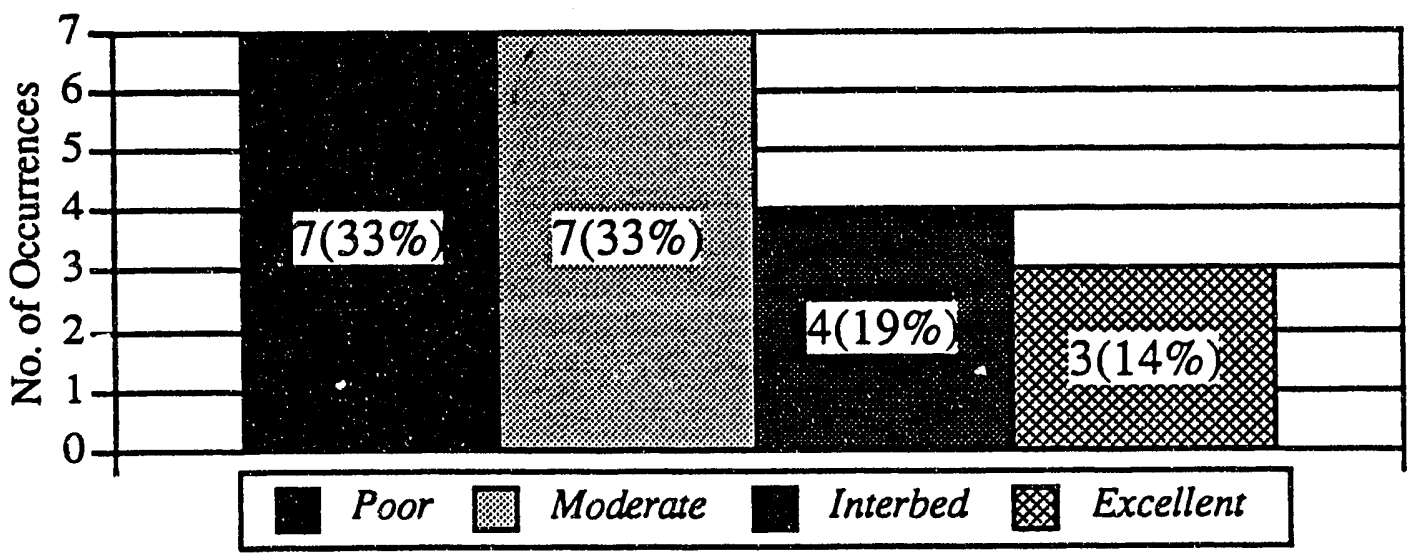

Figure 24. Ranking distribution for spatial correlations between aquifer intervals identified by Jones (1961) and basalt flow group contacts identified by Anderson (1991).

In general, the individual aquifer intervals of Jones (1961) carnot be correlated with any specific flow group (or flow group contact) within the ICPP area. The lack of spatial correlation between aquifers and flow groups is graphically demonstrated by the comparative geologic cross section shown in Figure 23. For example, the location of aquifer "A" correlates with flow groups F, F-FG, F, EF, and E-EF from north to south 
within wells $43,47,48,51$, and 77, respectively. Aquifer "A" occurs both within the interiors of flow groups as well as at or near the geologic contacts between flow groups. These correlations show that aquifer " $\mathrm{A}$ " crosses flow group contacts and therefore does not appear to be spatially controlled by such geologic boundaries. Similar spatial relationships also exist within aquifers "B" through " $D$ ". The poor degree of spatial correlation between the inferred aquifers and flow group contacts is also demonstrated by examining aquifer correlations for a single flow group contact within Figure 23. For example, the geologic contact between flow groups $\mathrm{F}$ and $\mathrm{FG}$, although reasonably welldefined by slight to moderate borehole enlargements in wells $43,47,48,49$ and 51 , cannot be correlated with a single, unique aquifer interval using the hydrostratigraphic interpretations of Jones (1961). The F-FG flow contact is correlated with aquifers "B", "A", "B", and "D" in wells 43, 47, 48, and 51, respectively (see Table 7).

Anderson's lithostratigraphic interpretations identify a laterally continuous interbed at an elevation of about 4385 to 4333 feet (MSL) in wells $47,48,51$, and 77 (see Figure 23) which is believed by the author to represent a well-defined stratigraphic marker bed across the ICPP area. Poor spatial correlation exists between this interbed and the aquifers identified by Jones (1961). Aquifers " $C$ " and " $D$ " both appear to intersect and/or cross this interbed between wells 43 and 51 as shown on Figure 23. This implies that these "flowtop" aquifers are not coincident with laterally continuous, time-stratigraphic flow contact units as suggested by Jones (1961).

Flow groups $F, F G$, and $G$ are each believed to be comprised of a single basalt flow unit (Anderson, 1991, p. 21) containing typical intraflow stratigraphy as shown in Figure 5. Under these conditions, highly permeable zones of vesicular, brecciated, or platy basalt (interflows), typically associated with zones of anomalous borehole enlargement, are expected to occur at the tops and bottoms of these flow groups. However, significant borehole enlargements occur within the interiors of flows F, FG, and G, as shown by well-specific geophysical logs contained in Appendix 1. These data suggest that: a) 
borehole enlargements and related (inferred?) water-producing intervals may be controlled by vertical (?) fracturing within flow group interiors, and/or b) additional, currently undetected flow units and related geologic contacts (i.e., interflows) may exist within flow group interiors. Detailed downhole characterization involving updated geophysical logging, downhole television, and depth-specific hydraulic testing will be helpful to determine the exact cause, nature, and extent of these borehole diameter anomalies and their relative hydrologic significance.

\section{Conclusions of Model Comparison}

There is poor to moderate spatial correlation between the aquifers identified by Jones (1961) and the basalt flow group contacts identified by Anderson (1991) within monitoring wells $43,47,48,49,51$, and 77 at the ICPP. Aquifers interpreted by Jones occur both within flow group interiors and at or near the contacts between flow groups. The inferred spatial configuration of Jones's aquifers does not appear to be controlled by the basalt stratigraphy defined by Anderson (1991). Jones's flow top aquifers "C" and "D" intersect and/or cross a well-defined interbed zone located at an elevation of about 4385 to 4333 feet (MSL); this zone is believed to represent a time-stratigraphic horizon in the area of the six wells under consideration. These conditions suggest that Jones's aquifer interpretations are in error and may not accurately describe the spatial configuration of water-producing zones below the ICPP.

Field identification of hydrostratigraphic units such as discrete aquifers and related confining units requires knowledge of spatial trends in hydraulic conductivity and porosity (Seaber, 1988). These data have not been collected for depth-or flow-specific intervals in the upper portion of the Snake River Plain aquifer at the ICPP. The reliability of Jones's hydrostratigraphic conceptual model therefore must be questioned until supporting hydrologic evidence of its correctness is obtained through additional field testing. 
The hydrostratigraphic model of Jones (1961) is considered by the author as inadequate for describing aquifer configurations below the ICPP and therefore is not used in subsequent sections of this report. The lithostratigraphic model of Anderson (1991) is believed to provide a well-supported, conceptual geologic framework with which to compare and evaluate existing and future hydrologic data. However, Anderson's conceptual model has been developed with the specific objective of defining basalt stratigraphy and not with the intention of describing the occurrence of ground water or its movement within the upper portion of the Snake River Plain aquifer. The following chapters therefore use Anderson's model as the basis for analyzing existing hydrologic data while keeping in mind the original purpose and intent of the lithostratigraphic model. 


\section{CHAPTER 7 .}

\section{COMPARISON OF BOREHOLE FLOW MEASUREMENTS AND LITHOSTRATIGRAPHIC MODEL RESULTS}

\section{Introduction}

This chapter includes a qualitative evaluation of the spatial relationship between inhole ground water flow measurements conducted in the 1960's and the basalt stratigraphy described by Anderson (1991) in ICPP wells 42, 43, 48, 49, 51, 52 and 59. Within the constraints of the existing geologic database, this analysis tests the hypothesis that zones of measurable ground water flow into or out of a well are attributable to probable aquifers associated with the geologic contacts between the basalt flow groups intersected by the selected uncased borehole intervals. Knowledge of the geologic intervals which contribute to and/or receive intrawell ground water flow is important for understanding the vertical mixing of solutes within monitoring wells completed through multiple aquifers with different hydraulic heads.

\section{Description of Tracejector Tests}

During the period of 1963 through 1970, the USGS studied small-scale vertical movement of ground water at the INEL by measuring vertical flow conditions within selected wellbores. The locations and intrawell flow patterns of monitoring wells evaluated at the ICPP during this period are shown in Figure 25. Fluid velocity was measured by releasing a small slug of radioactive tracer, generally iodine-131, into the wellbore interval of interest, and recording the time required for the slug to move vertically through the water column using a down-hole detector. Complete experimental procedures followed and detailed test results acquired from this work are discussed within a series of 


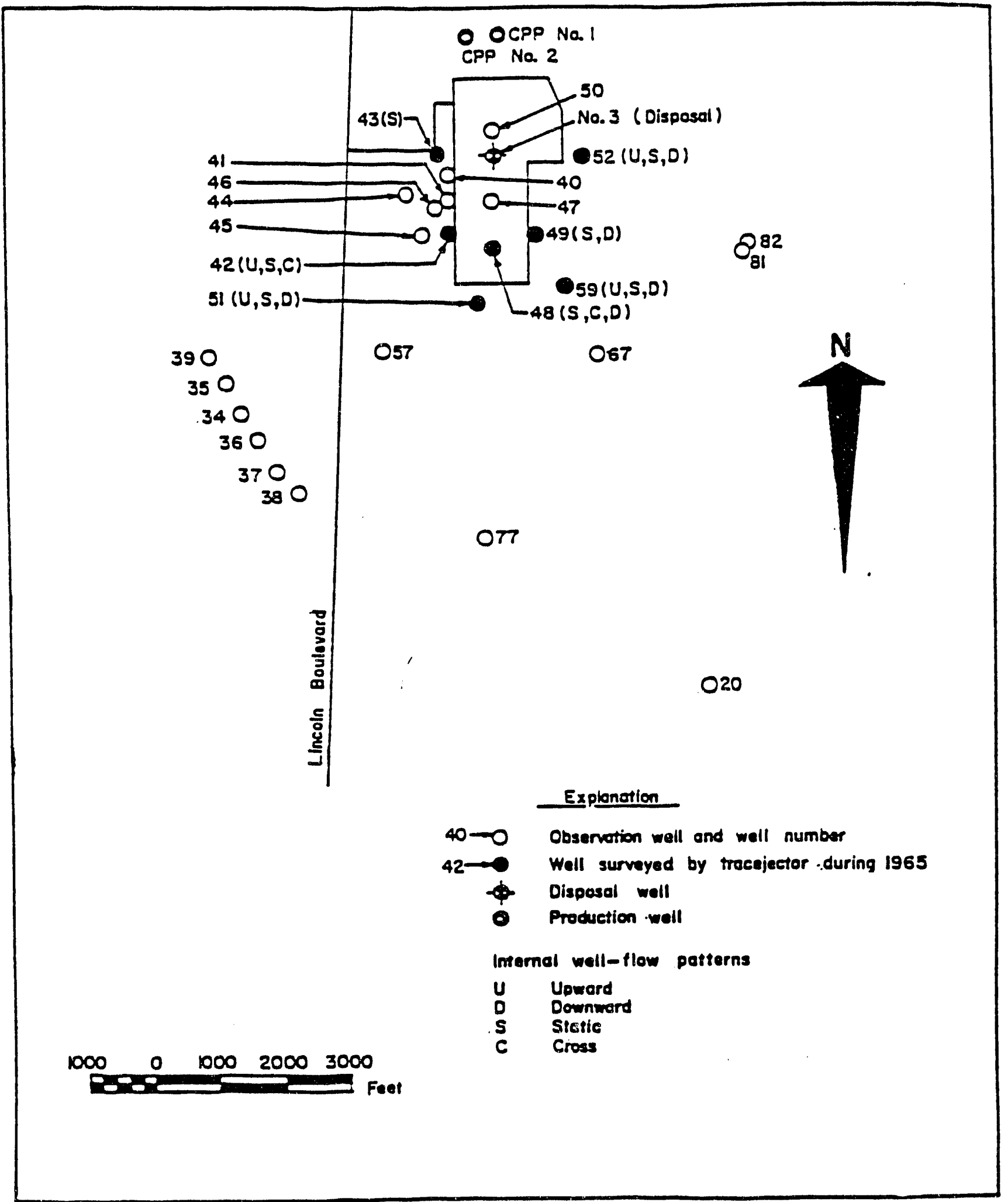

Figure 25. Map of the ICPP area showing the location of monitoring wells surveyed by the USGS in 1965 using the Tracejector probe (from Barraclough et al., 1967a). Observed directions of intrawell ground water flow within each tested well are also shown. 
Progress reports on the hydrology of the INEL (Morris et al., 1964, 1965; Barraclough et al., 1967a, 1967b; Robertson et al., 1974). Graphical results from six Tracejector tests performed within the ICPP monitoring well network are shown in Figure 26. These data represent intrawell flow conditions at the ICPP during a single period in 1965 when the injection well was discharging at a average rate of approximately 1 million gpd to the regional aquifer (Barraclough et al., 1967a, p. 97). Vertical head gradients are described by previous workers as being induced by waste discharges from the injection well and temporally variable pumping from the ICPP production wells (Barraclough et al., 1967a). These induced hydraulic gradients are believed to represent the primary driving force behind the intrawell ground water flow recorded by Tracejector logging in selected ICPP monitoring wells.

The general conclusion drawn from these tests by previous investigators is that no simple or recurring pattern of vertical ground water flow is immediately detectable at the ICPP (Barraclough et al., 1967a). At any particular depth flow may be upwards, downwards, horizontal or stagnant depending on the borehole under consideration. Results of identical testing procedures performed under rediuced injection conditions ( .9 million gpd) at CPP-3 show a reversal in flow directions at selected depth intervals in monitoring wells 48 and 52 (Barraclough et al., 1967a, p. 97). Flow reversals were attributed to changing head conditions within the aquifer, caused by small-scale changes in nearby pumping and disposal activities (Barraclough et al., 1967a, p. 98). These results led previous investigators to describe the aquifer as a very complex, heterogeneous, anisotropic flow system in which imposed hydraulic stresses may have significant and unpredictable effects on the ground water flow field. Minute changes in hydraulic head, due to pumping or waste disposal activities in the ICPP area, may cause reversals in the direction of vertical ground water flow between individual "flow-top aquifers". Such changes were observed by previous investigators to occur over relatively short periods of time, in some instances less than an hour (Barraclough et al., 1967a, p. 98). 

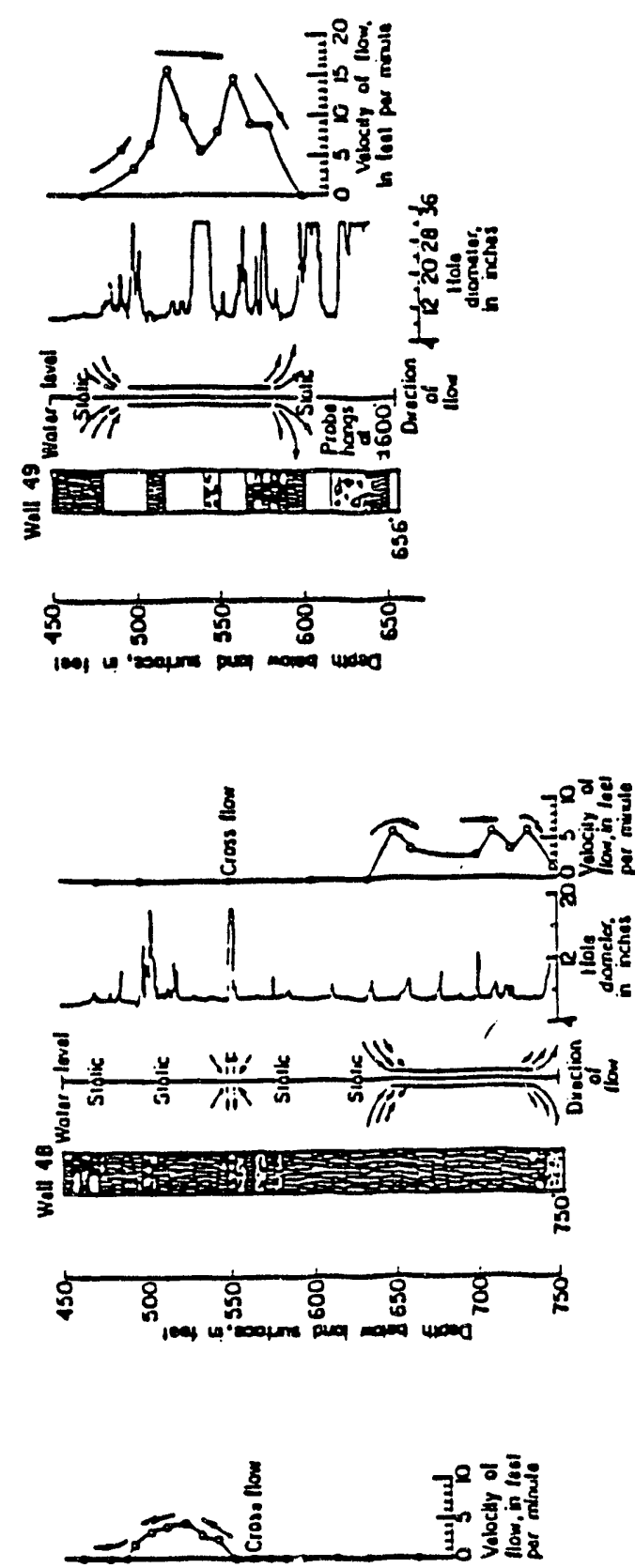

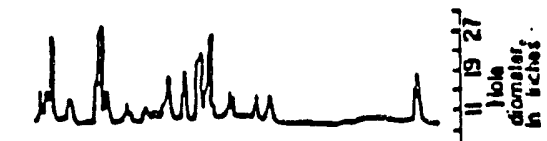

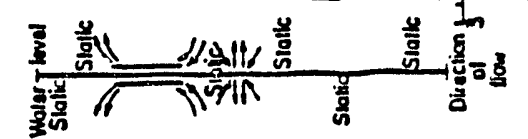

4 हnd

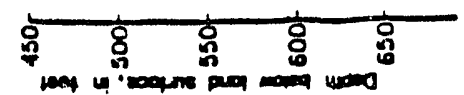

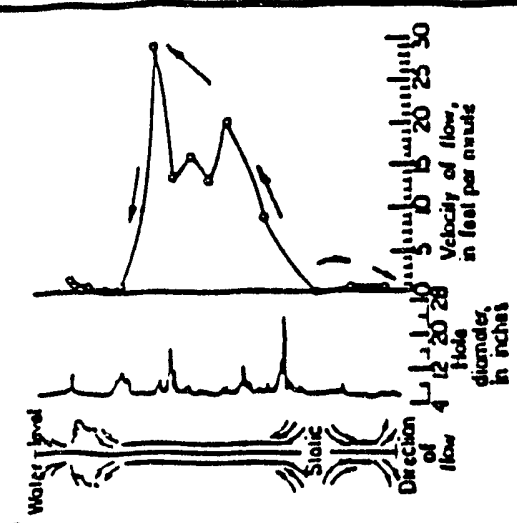

\%
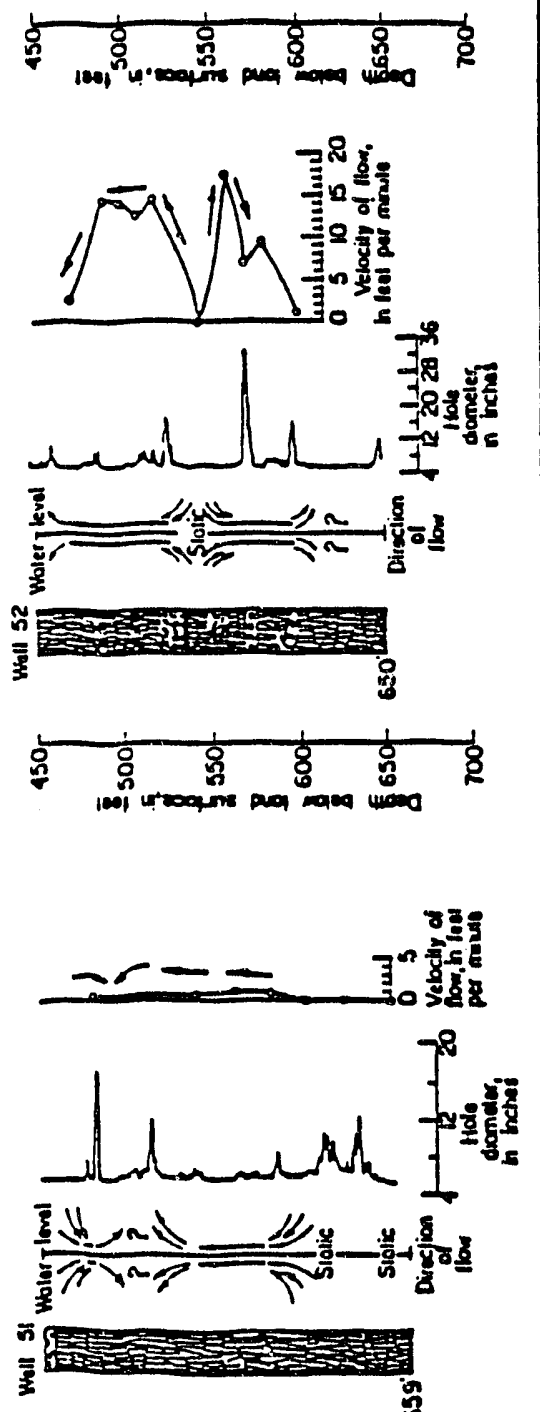

察

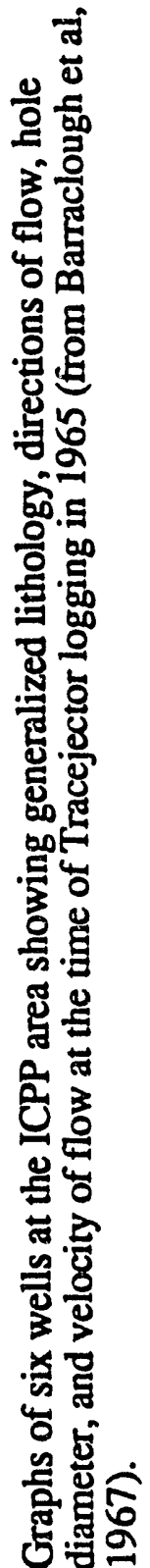




\section{Method of Comparison}

Wells $43,48,49$, and 51 have been selected for primary consideration in this study because the elevations of geologic contacts between individual basalt flow groups are known for these wells (Anderson, 1991). Wells 42, 52, and 59 also are considered in this analysis because the contact elevations between composite stratigraphic units are well defined. Composite stratigraphic units are comprised of multiple basalt flow groups and related interbeds of similar age and source and are also used by Anderson (1991) to describe the stratigraphy of the ICPP area (Anderson, 1991, p. 16).

Tracejector test results have been drawn adjacent to the lithostratigraphic intervals and caliper logs for each well under consideration (see Appendix 2, p. 130-136). These drawings permit graphical correlation between zones of in-hole ground water flow and the lithostratigraphic flow groups described in Chapter 4. Lithostratigraphic cross sections, showing generalized intrawell flow, data, have been constructed between the seven wells tested by Tracejector methods at the ICPP, and are shown in Figures 27 and 28. These cross sections are used to evaluate the spatial correlations and trends of contributing and receiving zones with respect to inferred basalt contacts at the scale of the ICPP.

\section{Analysis and Discussion of Results}

A comparative summary of the spatial correlation between basalt flow group contacts and the direction of intrawell ground water flow for monitoring wells $42,48,49$, $51,52,59$ is provided in Table 8. The spatial relationships summarized in Table 8 are graphically displayed in cross sectional form in Figures 27 and 28, with well-specific log comparisons provided in Appendix 2, pages 130-136.

Tracejector log results for well 43 show no indication of intrawell ground water flow. This indicates that hydraulic head was uniform over the open borehole interval at the 


\section{Well 43}

Ref. Elev. $4917 \mathrm{ft}$

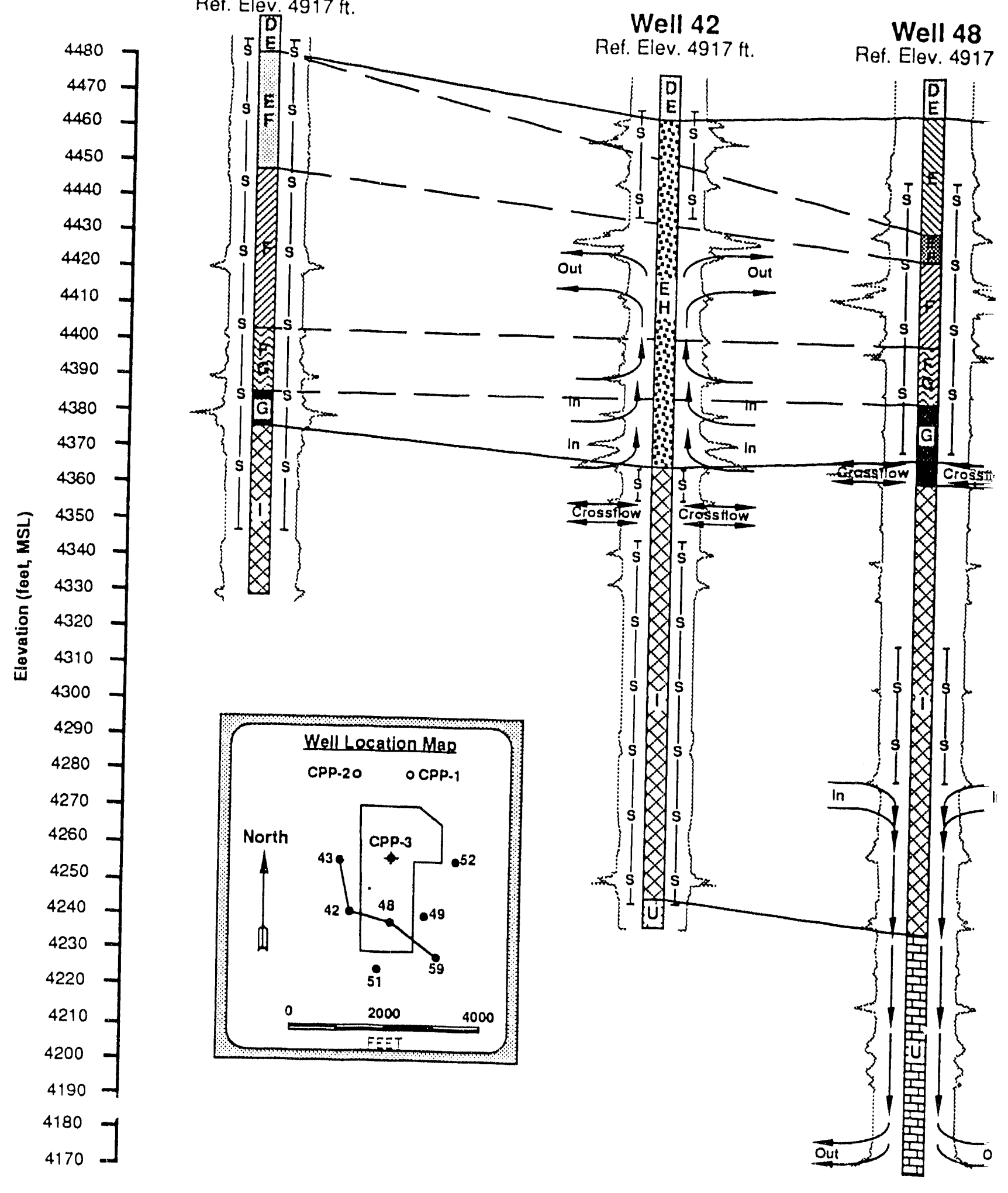

Vertical Exaggeration

Figure 27. Cross section $Y-Y^{\prime}$ ihrou? results (after Barraclough et al., 1967a) Anderson (1991). 


\section{Well 59}

Ref. Elev. $4915 \mathrm{ft}$.

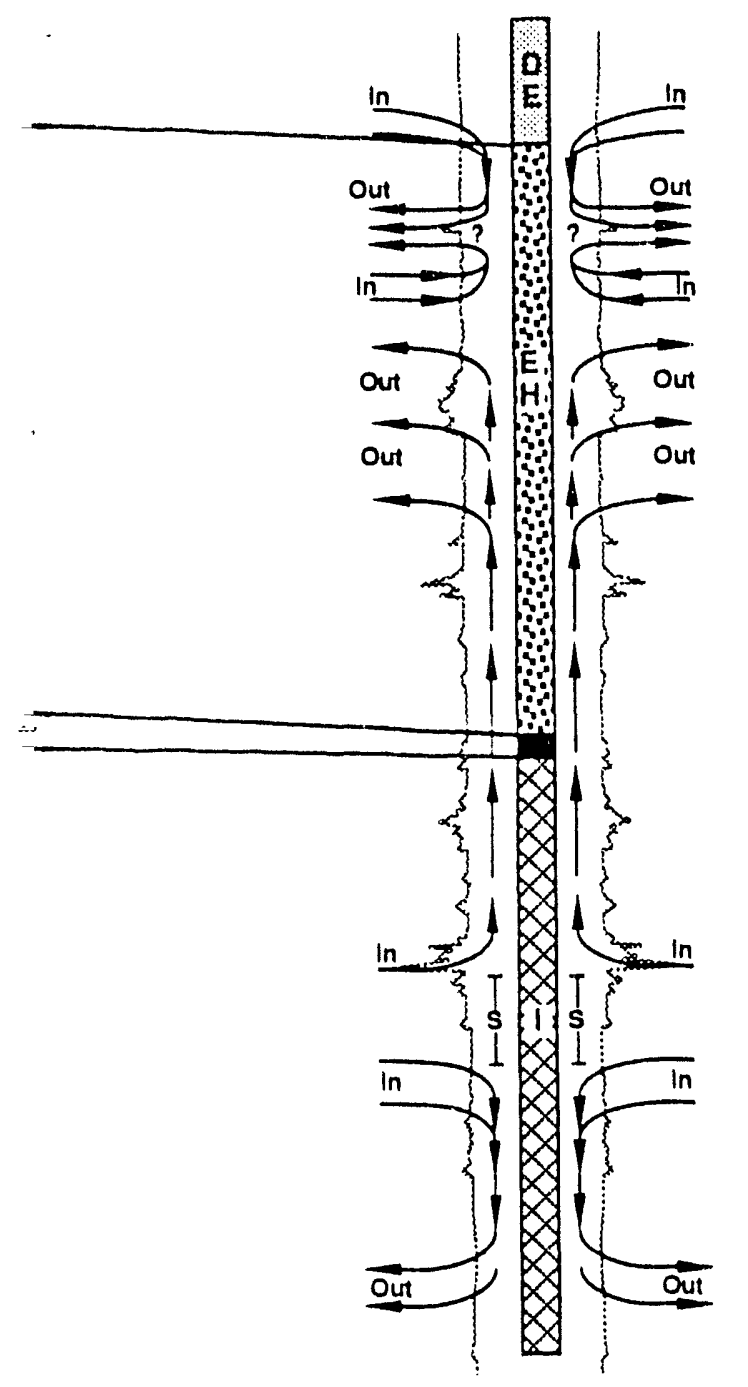

EXPLANATION

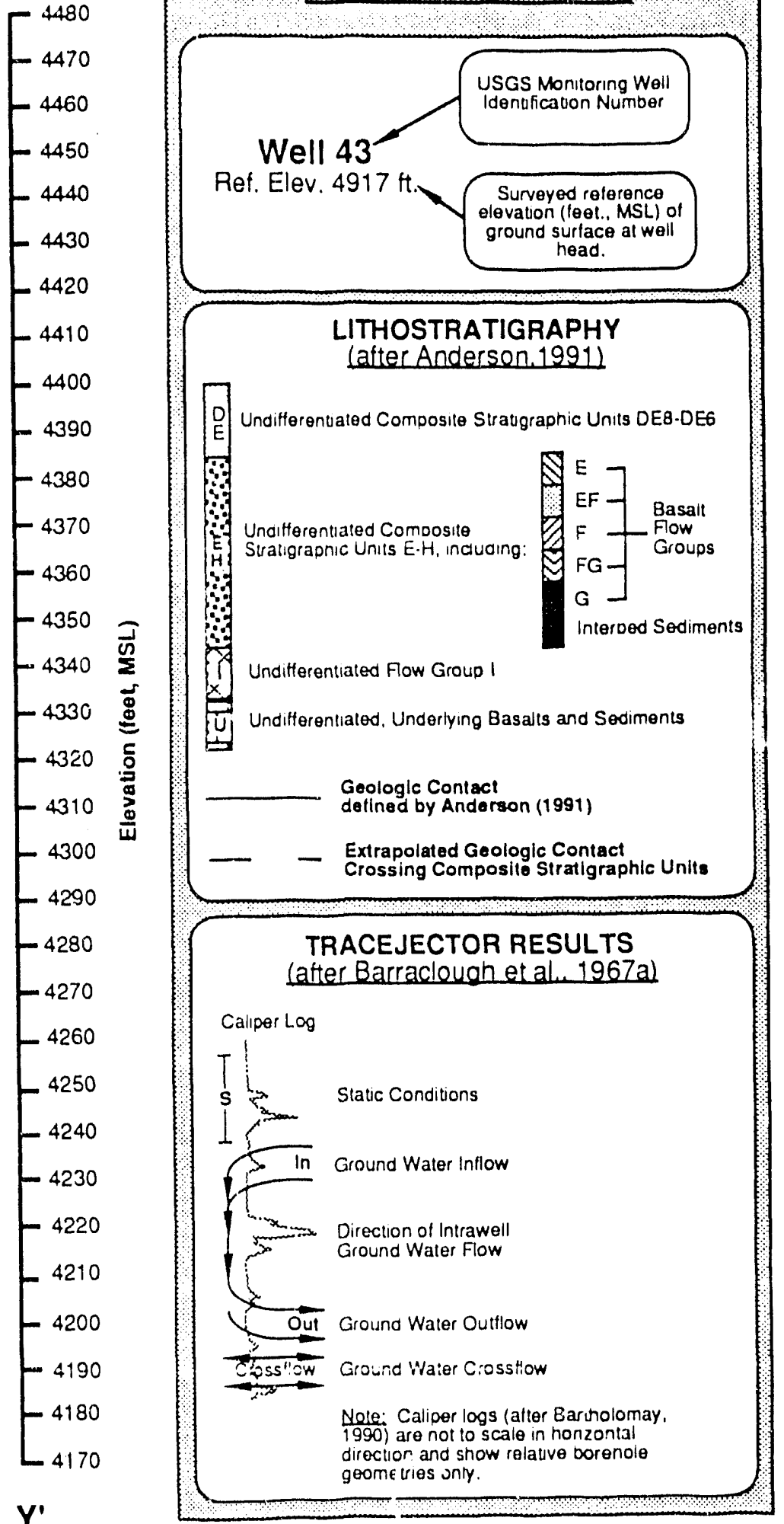




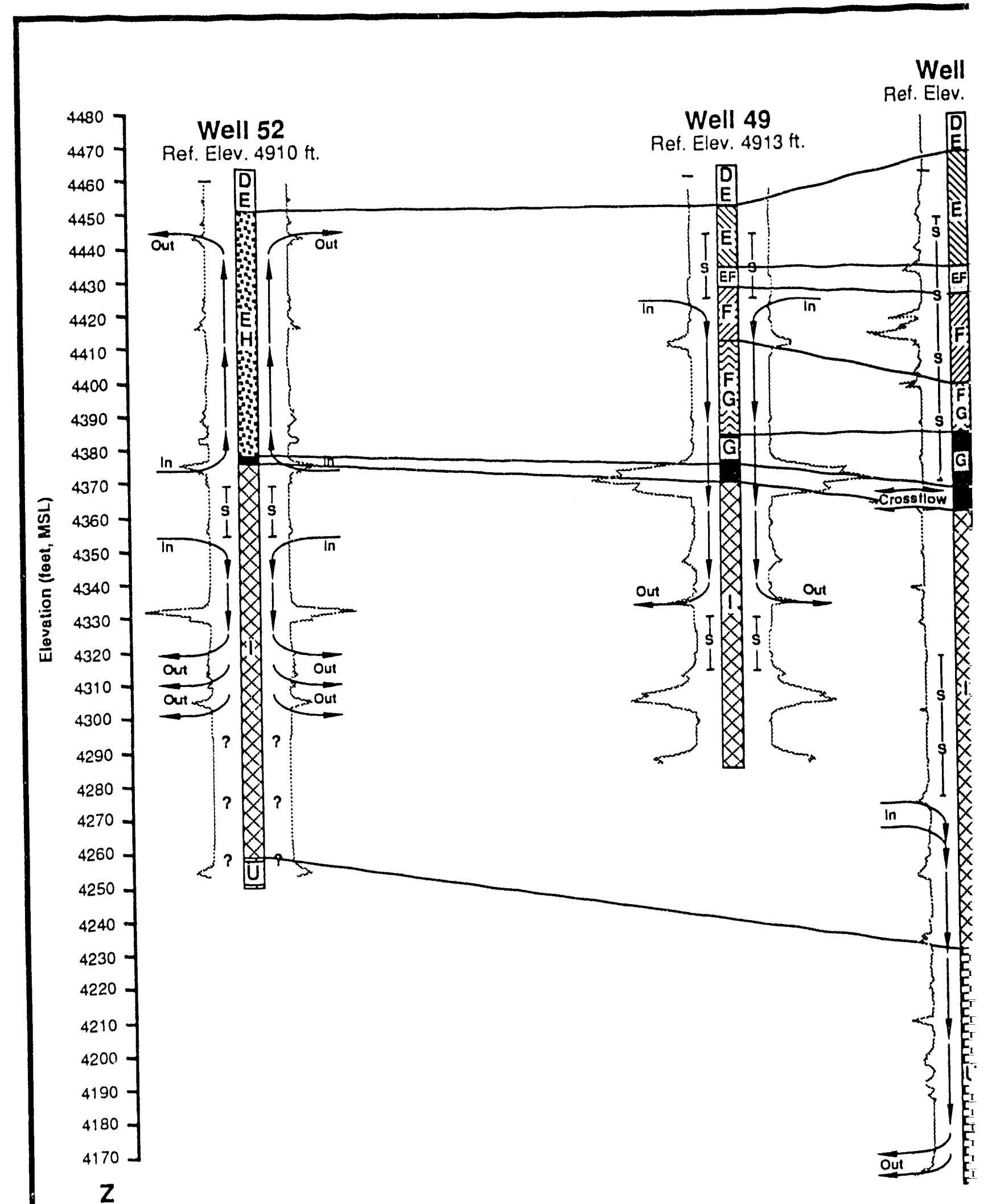

Vertical Exaggerati

Figure 28. Cross section Z-Z' thro results (after Barraclough et al., 1967 Anderson (1991). 
48

$4917 \mathrm{ft}$.

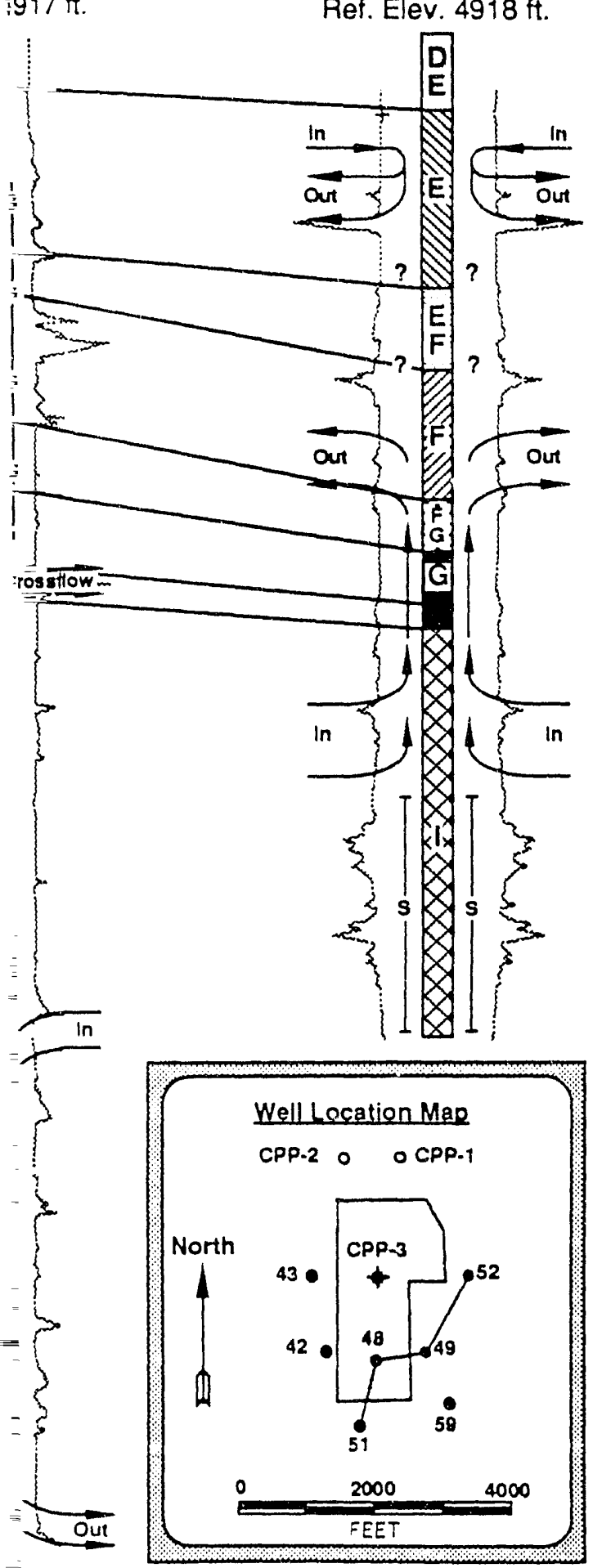

4480

4470

$-4460$

$-4450$

$-4440$

$-4430$

$-4420$

$-4410$

$-4400$

- 4390

$-4380$

- 4370

$-4360$

$-4350$

$-4340$

4330

4320

4310

$-4300$

$-4290$

- 4280

$-4270$

$-4260$

$-4250$

$-4240$

$-4230$

$-4220$

$-4210$

$-4200$

$-4190$

- 4180

4170

$\mathbf{Z}^{\prime}$
EXPLANATION

Well 43

Ref. Elev. $4917 \mathrm{H}$

USGS Monitorıng Weil Identification Number

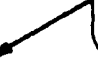
levation (feet., MSL) of ground surtace at weil head.

LITHOSTRATIGRAPHY (after Anderson. 1991)

Undifferentiated Composite Stratigraphic Units DE8-DEG

Uncifferentiated Composite

Stratigraphic Units E.H, including:

H.

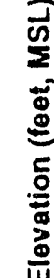

눈

Undifferentiated Fow Group

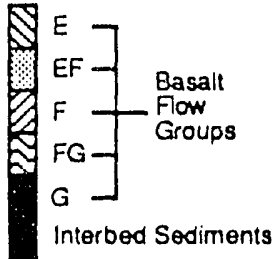

Undifferentiated, Underlying Basalts and Sediments

Geologic Contact

defined by Anderson (1991)

- - - Extrapolated Goologle Contact Crossing Composite Stratigraphic Units

TRACEJECTOR RESULTS (after Barraclough et al. 1967a)

Caliper Log

$T$

$S$ Static Conditions

Ground Water Inflow

Direction of Intrawell

Ground Water Flow

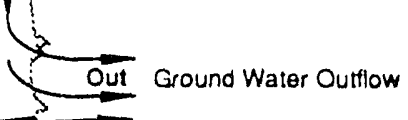

Chossilow Ground Water Crossflow

Note: Caliper logs (after Bartholomay. 1990) are not lo scale in honzontal direction and show relatve borehole geometries only.

\section{$\equiv n: 9.7 x$}

gh the ICPP area showing Tracejector 1 and lithostratigraphic interpretations of 


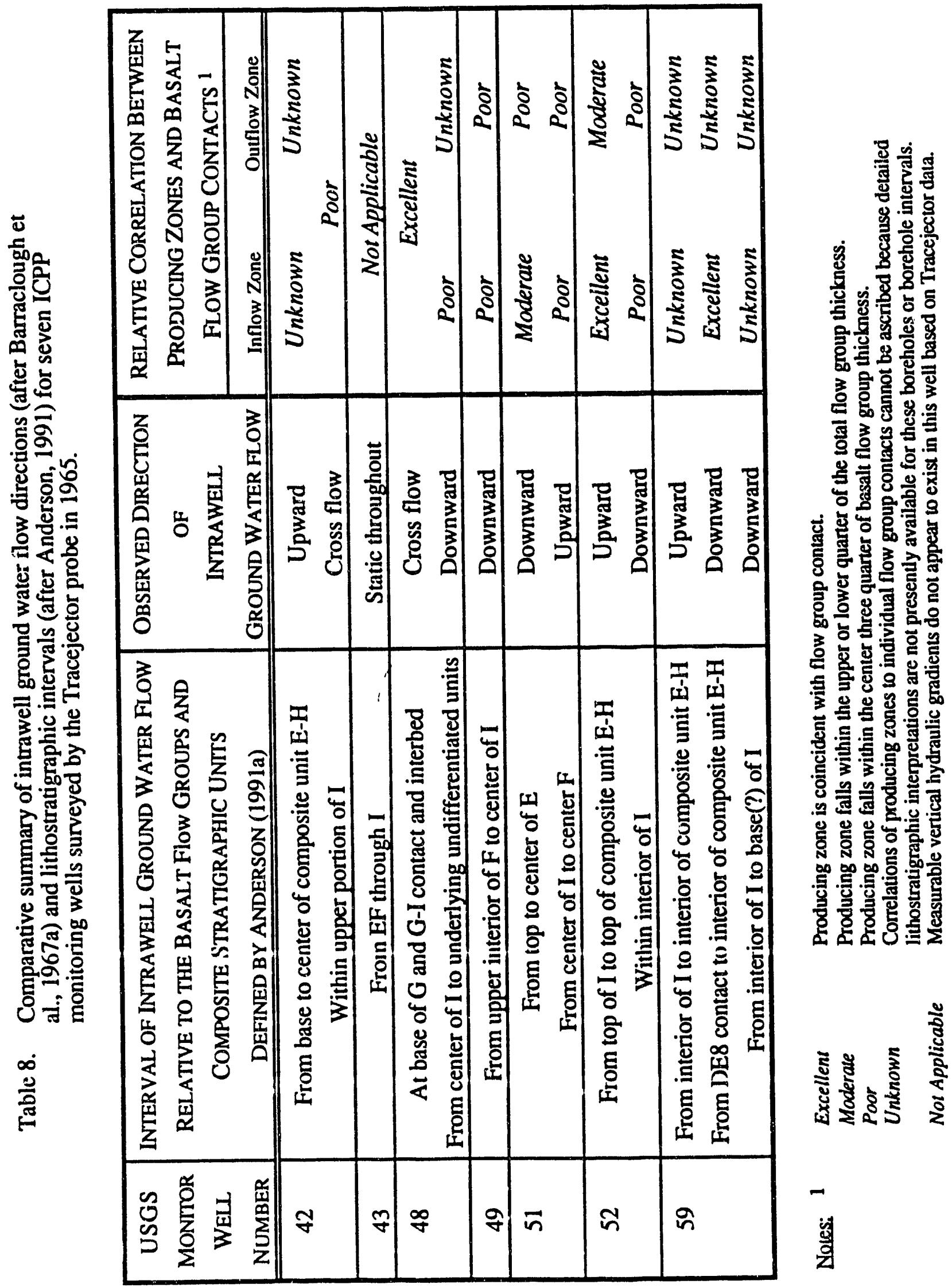


time of Tracejector logging. Flow conditions in this well are therefore described as "static" on Figure 27.

Well 48 is hydrodynamically static through flow groups E-F and shows very low velocity cross-flow within the sedimentary interbed which separates flow groups $G$ and $I$. Static conditions also prevail in the upper part of flow group I from 600 to 640 feet (4317 to $4277 \mathrm{ft}$, MSL). A zone of moderate velocity downward flow is noted in the lower 100 feet of well 48, beginning in flow group I. However, basalt flow contacts have not been identified within the lower portion of well 48. Downward flow originates from the center of flow group I at about 640 feet and terminates at a depth of about 740 to 745 feet (4177 to $4172 \mathrm{ft}, \mathrm{MSL}$ ) within the undifferentiated basalt and sediment group which underlies flow group I.

Well 49 displays a downward component of ground water flow between the depths of 490 feet to 580 feet (4423 to $4333 \mathrm{ft} ., \mathrm{MSL}$ ). Ground water in-flow appears to originate at 490 feet, within the middle half of flow group F, with a marked increase in velocity at the center of FG. Downward flow continues until the center of flow group I, with a slight reduction in flow velocity at the depth of flow group $\mathrm{G}$ and the underlying sedimentary interbed. Downward ground water flow occurs at a moderately high velocity across the contact between composite stratigraphic units E-G and I.

Well 51 displays two distinct zones of vertical ground water flow, both with very low velocities. A short interval of downward flow begins (in-flow) within the upper portion of flow group $\mathrm{E}$ at about $465 \mathrm{feet}(4453 \mathrm{ft}$., MSL) with water leaving the borehole (out-flow) in the center of flow group E. Deeper in the well, ground water in-flow occurs within the center of flow group $i$ and is directed upwards across the I-G composite stratigraphic unit contact. Ground water exits the wellbore from 525 to 535 feet (4393 to $4383 \mathrm{ft}$., MSL) within the interior and lower portions of flow group F. Ground water is essentially static from 600 to 650 feet (4318 to $4268 \mathrm{ft}$., MSL) within the lower portion of flow group I below the zone of upward water movement. 
Well 42 is dominated by upward ground water flow with inflow occurring from 550 to 525 feet ( 4367 to $4392 \mathrm{ft}$., MSL); just above the sedimentary interbed which separates undifferentiated composite unit E-H from basalt flow group I. Ground water leaves the borehole from 500 to 490 feet ( 4417 to $4427 \mathrm{ft}$. MSL) within the center of undifferentiated composite unit E-H. This outflow zone may include a basalt flow group contact although detailed lithostratigraphic interpretations do not exist currently for this interval A zone of cross flow is noted in the upper-central portion of basalt group I at a zone of moderate borehole enlargement. Static conditions exist from 570 to 670 feet (4347 to $4247 \mathrm{ft}$., MSL) within most of flow group I while cross flow occurs form 560 to 565 feet ( 4357 to $4352 \mathrm{ft}$., MSL) within the upper portion of flow group I.

Well 52 also displays two distinct zones of vertical ground water flow. Both zones show relatively high velocity flow rates and are separated by a stagnant interval at a depth of 540 to 555 feet ( 4370 to $4355 \mathrm{ft}$, MSL) within the upper portion of flow group I. The 70-foot thick, upper flow zone occurs from the top of flow group I to within the upper portion of undifferentiated composite stratigraphic unit E-H. A zone of downward ground water flow exists within the interior portion of flow group I. Static flow conditions exists across the contact between composite units E-H and I.

A relatively strong upward flow component exists in well 59 between composite stratigraphic units I and E-H. Ground water flows into the well within the center of flow group I at about 590 feet ( $4325 \mathrm{ft}$., MSL) and moves up the borehole at a relatively high velocity until being discharged within the center of composite unit E-H at a depth of 490 to 515 feet ( 4425 to $4400 \mathrm{ft}$, MSL). Correlation of contributing and receiving zones with basalt flow-specific intervals is not possible in this well based on currently available lithostratigraphic interpretations. A complicated system of inflows and outflows is observed from 455 to 480 feet ( 4460 to $4435 \mathrm{ft}$, MSL). An interval of measurable inflow is located adjacent to the contact between undifferentiated composite units E-H and DE6DE8. 
Zones of inflow and outflow within these seven wells show a relatively poor degree of spatial correlation with the basalt flow group contacts identified by Anderson (1991) as shown on Figures 27 and 28. A total of 14 of the 22 intervals of ground water inflow and/or outflow, hereafter referred to as "producing zones", have been given qualitative correlation ratings. The remaining 8 producing zones, labelled as Unknown on Table 8 , cannot be rated for spatial correlation because of a lack of lithostratigraphic definition within these depth intervals. Only three (21\%) of the producing zones show direct spatial correlation with basalt flow group contacts. These correlations are rated qualitatively as Excellent on Table 8. A total of nine (64\%) of the correlatable producing zones falls within the center three quarters of basalt flow groups, and are termed as Poor correlations on Table 8. A Moderate correlation, showing a producing zone within the upper or lower quarter of the total flow group thickness, occurs only twice; representing $14 \%$ percent of the total correlatable producing zones.

A recurring spatial pattern of intrawell flow is not demonstrated by the seven Tracejector tests evaluated in this study, as shown on Figures 27 and 28. For example, well 49 indicates that the interior of flow group $F$ contributes ground water to the intrawell flow system with discharge within flow group I. In contrast, well 51 suggests that the basal-interior section of flow group F receives ground water from flow group I, whereas well 48 suggests that flow group $\mathrm{F}$ is not active as a producing zone. Cross flow is observed within the 550 foot interbed in well 48 , although this feature does not appear to influence the intrawell flow conditions in wells 49 and 51. Upward ground water flow originates from this interbed in nearby wells 42 and 52, although outflow occurs at different stratigraphic intervals in each well. The occurrence and direction of intrawell ground water movement within basait flow group I does not have a recognizable pattern. Flow may be upwards, downwards, cross-hole, or static depending on the depth and borehole under consideration. The irregular occurrence and direction of ground water flow between composite stratigraphic unit E-H and unit I does not show a systematic pattern of 
intrawell ground water flow at the ICPP. Wells 42,51 , and 59 display upward flow across this contact whereas well 48 shows cross flow and well 49 demonstrates downward flow conditions. Well 42 shows static conditions at this contact while well 52 shows ground water inflow.

\section{Conclusions}

Poor overall spatial correlation exists between basalt flow group contacts (after Anderson, 1991) and Tracejector test results (after Barraclough et al., 1967a) compiled by the USGS in monitoring wells $42,43,48,49,51,52$, and 59 at the ICPP. Zones of ground water inflow and outflow (i.e., producing zones) occur more frequently within flow group interiors than at the inferred contacts between flow groups. This finding indicates that: a) existing subsurface geologic mapping is insufficient for describing the stratigraphic and/or structural controls of ground water flow, and/or b) water-producing zones do not occur strictly at contact zones between basalt flows groups, and/or c) Tracejector testing may not accurately describe the intrawell flow conditions within these monitoring wells.

A recurring spatial and/or directional pattern of intrawell ground water flow is not demonstrated by the available Tracejector data. Intrawell ground water movements described by these tests may be upwards, downwards, horizontal, or nonexistent (i.e., static) depending on the exact depth and well location under considcration. Changing hydraulic head conditions in the aquifer, caused by nearby pumping and disposal activities, impact vertical ground water gradients in a nonuniform manner within the seven ICPP monitoring wells considered in this analysis. These data suggest that the upper portion of the Snake River Plain aquifer is highly heterogeneous and anisotropic at the scale of the monitoring well network described by wells $42,43,49,48,51,52$ and 59 at the ICPP. 
Additional work is required to lefine the stratigraphic controls of ground water inflow and outflow in monitoring wells at the ICPP. Updated, depth-specific head measurements, downhole television logs, and heat-pulse flow meter logs (or equivalent) are necessary to better understand the hydrologic relationships between inferred lithostratigraphic units and existing intrawell flow conditions. Directional flow measurements within open borehole intervals should be derived for each monitoring well to determine the areal extent of vertical mixing under present site conditions. Visual inspection and description of measured (or suspected) water-producing intervals, using downhole television logs, will be helpful in characterizing the lithologic controls of intrawell ground water flow. 


\title{
CHAPTER 8
}

\section{GROUND WATER QUALITY SAMPLING INTERVALS}

\author{
Introduction
}

Ground water quality samples are collected from each of the ICPP monitoring wells by the USGS on a quarterly or semi-annual basis. These samples currently are collected using dedicated submersible sampling pumps which are set at fixed elevations in most monitoring wells. This chapter includes an evaluation of the spatial relationship between these ground water sampling intervals and the lithostratigraphic zones defined by Anderson (1991) for selected ICPP monitoring wells. This exercise qualitatively defines which lithostratigraphic zones are most likely to be contributing to the ground water samples currently collected during routine monitoring in these wells.

Ground water quality samples collected from ICPP wells are used to delineate and monitor the areal extent of aqueous contamination caused by on-site waste disposal practices (Robertson et al., 1974; Mann and Knobel, 1987, 1988; Pittman et al., 1988; Mann and Cecil, 1990; Mann, 1990). Ground water sampling results are also used to calibrate and verify the numerical solute transport models constructed for the southern INEL (Robertson and Barraclough, 1973́, Robertson, 1974; Lewis and Goldstein, 1982). These models are used to predict the fate and transport of aqueous contaminants, such as strontium-90, tritium, and chloride, downgradient of the waste disposal facilities at the ICPP and TRA.

The USGS has been responsible for the collection and reporting of ground water quality sampling data at the ICPP since site activities began in 1949 (Bagby et al., 1985). Sample collection methods have historically involved the use of bailers and thief-type samplers (Jones, 1961; Robertson et al., 1974, Bagby et al., 1985). Ground water 
samples are currently collected from most ICPP wells using dedicated, submersible pumps (Jensen, USGS, personal communication). The only exception to this rule occurs in RCRA compliance wells 121,122 , and 123 which are equipped with piston-type displacement pumps (Golder Associates, 1990).

The installation of dedicated, submersible sampling pumps in ICPP monitoring wells began in 1975 and was completed in 1990 (Jensen, personal communication). Submersible pumps have been chosen for dedicated installations because they can: a) quickly purge large volumes of ground water at relatively high pumping heads and $b$ ) deliver environmentally representative samples for most of the geochemical parameter suites of concem, including metals, radionuclides, and volatile organic compounds (Mann, personal communication). The reader is referred to Mann and Knobel (1987, 1988), Mann (1990), and Mann and Cecil (1990) for a thorough treatment of the methods used for ground water sample collection at the INEL. A detailed evaluation and comparison of various ground water sampling technologies is provided by Scalf et al. (1981), U.S. EPA (1985), and Nielson (1991).

Monitoring wells completed in the regional aquifer system at the ICPP are commonly uncased over hundreds of feet and therefore intersect multiple water-bearing zones (see Chapters 4 through 7 of this report). To date, however, the USGS has not conducted a thorough quantitative analysis of the differences in ground water quality which may occur between these water-bearing intervals. Jones (1961) performed a preliminary investigation of the chemical and radiological characteristics of ground water at various depths within selected ICPP wells using inflatable straddle-packer equipment. His sampling results demonstrated that considerable geochemical variability existed in many of the ICPP wells during the period when liquid wastes were being introduced directly to the aquifer through well CPP-3. Jones believed that aquifer " $D$ " was locally the most geochemically and hydraulically important interval in this multi-aquifer system based on the spatial distribution of sodium and tritium in ground waters samples (Jones, 1961, p. 56). 
However, plans for aquifer- and/or depth-specific sampling and analysis of ground water at the ICPP have not been discussed in the published literature since the preliminary straddle-packer experiments were discontinued by the USGS in 1962 (Morris et al., 1963).

\section{Application of Submersible Sampling Pumps at the ICPP}

Ground water samples collected from ICPP boreholes are most likely withdrawn from the water-bearing zone(s) nearest to the dedicated, submersible pump intakes. This highly localized sampling effect is a function of the extremely high hydraulic conductivity of the water producing zones relative to the low pumping rates achieved during purging and sampling periods. The average maximum pumping rate for the dedicated ICPP sampling pumps is approximately $16 \mathrm{gpm}$ (Jensen, personal communication). Mean hydraulic conductivity of the composite aquifer system at the INEL is reported to range from $8.6 \times 10^{-3}$ to $5.5 \times 10^{3}$ feet/day (Ackerman, 1991) and can be as high as $9.8 \times 10^{3} \mathrm{feet} /$ day (Lindholm and Vaccaro, 1988). Hydraulic conductivity of individual "flow-top aquifers" at the ICPP is expected to be greater than these vertically averaged $K$ values although depth-specific $\mathrm{K}$ values have not been measured directly in any of the ICPP wells at this time. These hydraulic conditions suggest that purging and sampling of monitoring wells influence only a very small portion of the uncased interval of the well, that portion nearest to the pump intake.

The vertical zone of hydraulic influence created by sampling pumps during purging is related directly to the hydraulic conductivity and thickness of each water-producing zone encountered in the open wellbore and the location of the pump relative to these intervals. Aquifer heterogeneity therefore plays an important role in determining which hydrogeologic intervals contribute to a given ground water sample. The zone of hydraulic influence will be comparatively small if the sampling pump is positioned nearby a highly transmissive geologic unit, such as a flow top or highly interconnected vesicular zone. A larger zone of 
hydraulic influence will be achieved during the pre-sampling purge period if less transmissive zones, such as massive flow interiors or fine-grained interbeds, are located adjacent to a sampling pump intake. Once the zone of influence reaches a more transmissive horizon (a positive boundary), little additional zonal enlargement will occur and most of the purged and sampled ground water will be derived from the more transmissive zone. The contribution ratio of formation waters withdrawn from each hydraulically affected hydrogeologic unit will be proportional to the ratio of transmissivities for those units. Under any circumstance, the collected ground water sample represents a composite of all the water-bearing intervals encountered by the zone of hydraulic influence during the purging period.

These conditions have led the author to assume that ground water samples are withdrawn predominantly from the basalt flow groups immediately adjacent to the dedicated sampling pumps. This is a reasonable assumption given the relatively low pumping rates achieved during purging and the expectedly high hydraulic conductivity of the water-producing zones. Possible effects of vertical hydraulic gradients and associated water movement within individual boreholes are ignored in this analysis given that their occurrence, direction, and magnitude are largely unknown under present conditions.

Quantitative analysis of the area of hydraulic influence around a given sampling pump is not possible without detailed knowledge of pumping rates, hydraulic properties, head conditions and/or aquifer geometries within each hydrogeologic unit intersected by a the open borehole interval. Determinations of horizontal and vertical hydraulic conductivity, hydraulic head, and effective aquifer thickness for each basalt flow do not exist currently in the USGS database. Representative values of these parameters are difficult to obtain due to the prevalence of aquifer heterogeneity and the need for elaborate and highly specialized downhole testing apparatus. 


\section{Discussion of Results}

Sampling pump elevations and related lithostratigraphic correlations for each of the thirty-one active ICPP monitoring wells are summarized in Table 9. Twenty of these wells are included on the interpretive geologic cross sections B- B', C-C', E-E' and F-F' of Anderson (1991) (see Figures 13-20). These intersected wells, hereafter referred to as the "primary series", provide for detailed lithostratigraphic correlations because flow group contact elevations are graphically specified on the geologic sections. For the remaining eleven monitoring wells, hereafter referred to as the "secondary series", only the contact elevations between composite stratigraphic units are currently known (see Anderson, 1991, p. 66-71). The sarnpling pump intake elevation data, as provided by the USGS (Jensen, personal communication), are compared with Anderson's lithostratigraphic interpretations for each monitoring well. The approximate vertical positions of dedicated sampling pumps within the primary series wells are shown graphically on Figures 13-20.

Comparative evaluation of current pump settings and lithostratigraphic interpretations within the primary series wells shows that three wells are sampling ground water from flow group $E$, nine from flow group $E F$, six from flow group $F$, one from flow group FG and one from flow group I (see Table 9 and Figure 29). Pump settings do not occur at depths adjacent to flow groups $\mathrm{G}, \mathrm{H}$, or the underlying sedimentary interbed. This suggests that only ground water from the upper lithostratigraphic intervals of the Snake River Plain aquifer system is being geochemically evaluated under the current monitoring program in these twenty wells.

All but wells 67 and 123 of the secondary series have sampling pump intakes within the upper sixty percent of the composite stratigraphic unit E-H (see Table 9 and Figure 29). These data suggest that 10 of the secondary series wells also withdraw ground 


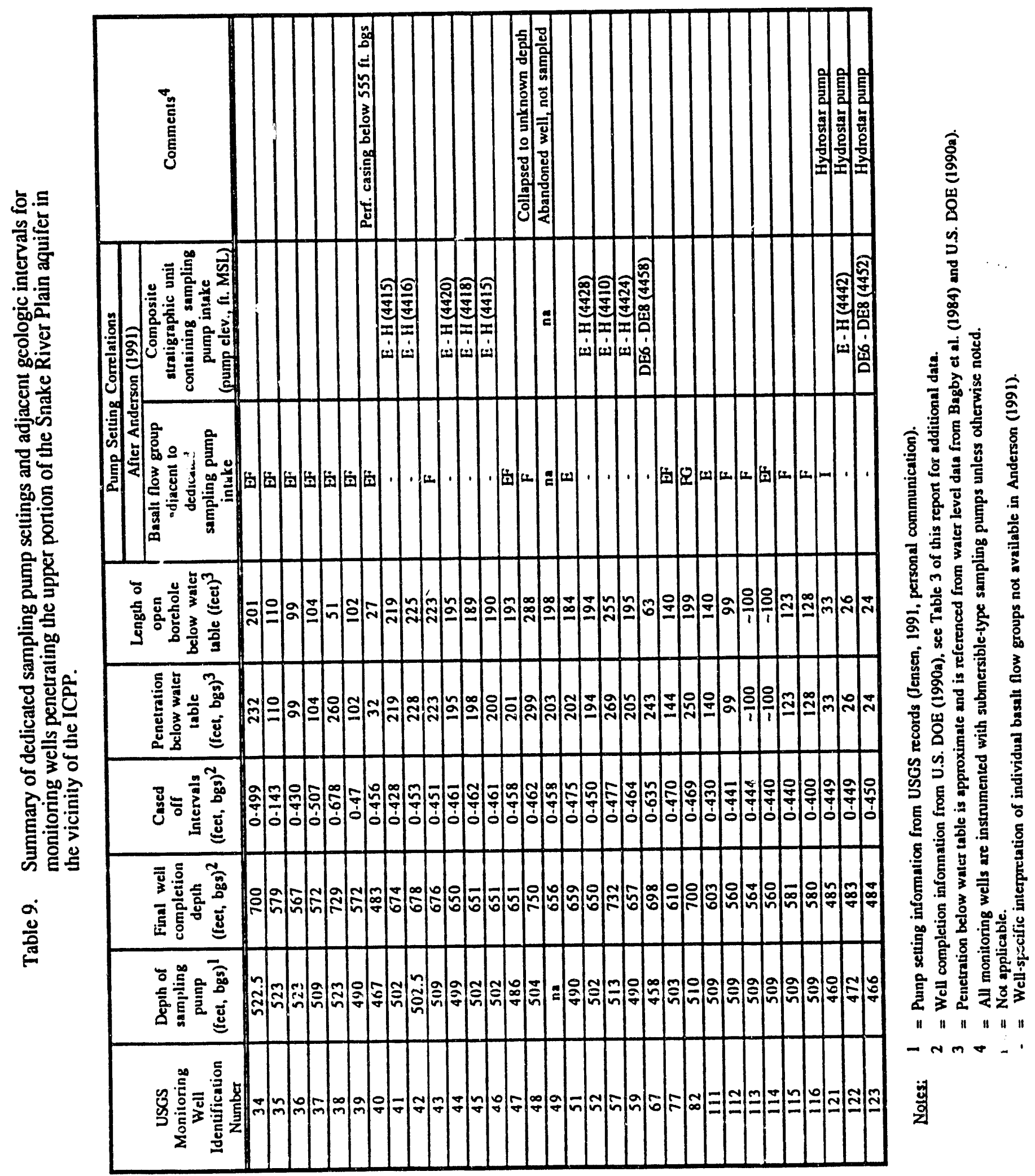


water samples from principally the upper portion of the regional aquifer system. The author cannot, however, identify flow group-specific contributing zones in these wells because of the current lack of supportive lithostratigraphic and hydrologic data.

Generalized Lithostratigraphy (After Anderson, 1991)

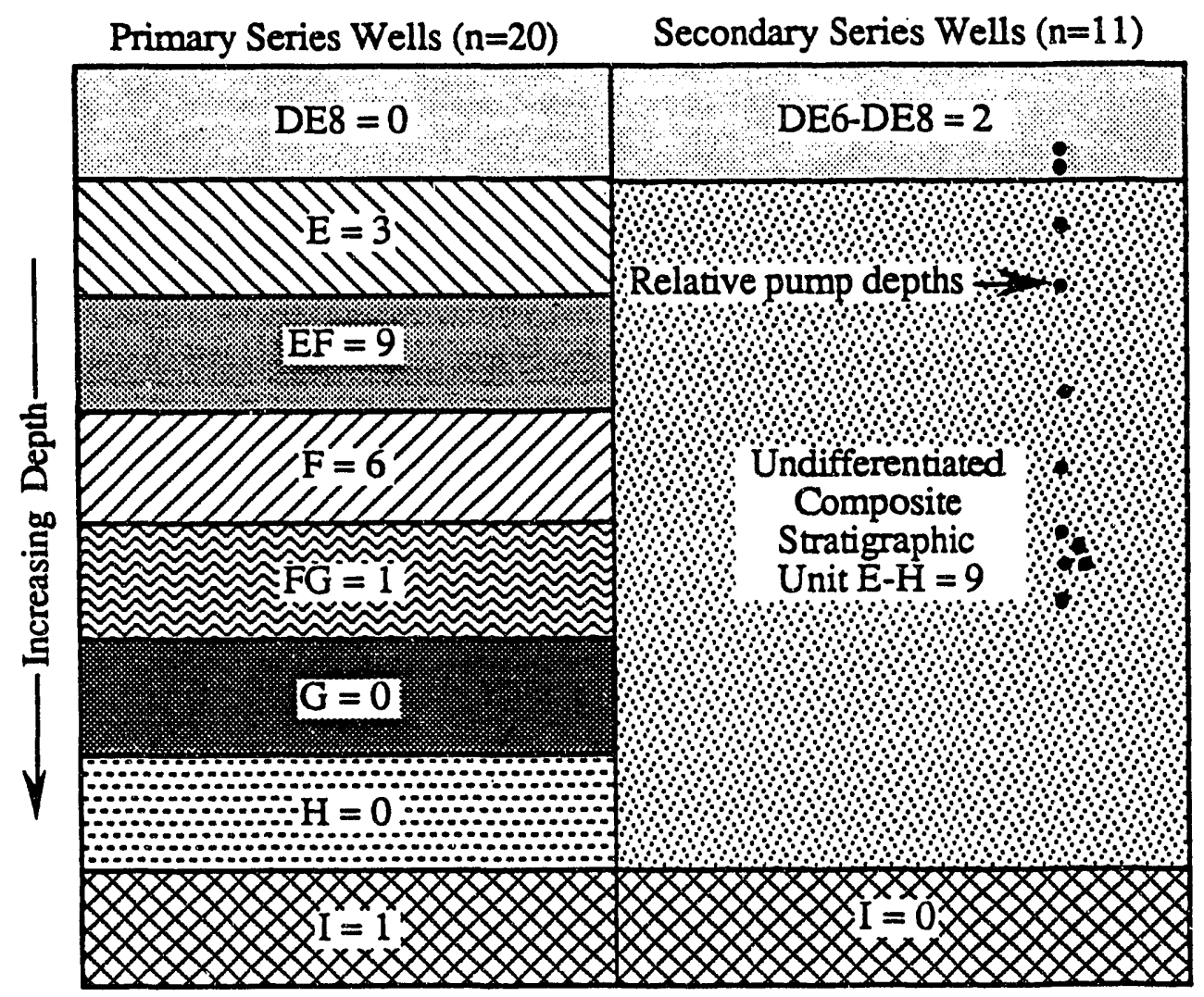

$\mathrm{F}=6$ : Indicates the total number of dedicated sampling pumps located within each lithostratigraphic interval.

Figure 29. Spatial distribution of dedicated sampling pumps relative to the lithostratigraphic units identified by Anderson (1991) within monitoring wells at the ICPP.

Well 121 is simated in the apparent upgradient direction relative to the ICPP and is the only ICPP well which is completed to sample ground water from flow group I. Well 121 is therefore of questionable value for describing the "background" geochemistry of the aquifer at large because it is not completed or sampled in the same composite stratigraphic composite unit as the other ICPP monitoring wells. By contrast, downgradient monitoring wells 67 and 123 are completed and sampled within the lower portion of the composite 
stratigraphic unit which includes flow groups DE-6 through DE-8. These two wells are each completed above the areally extensive sedimentary interbeds which separate flow groups DE-8 from $\mathrm{E}$ and flow groups $\mathrm{H}$ from I (see Figures 13-20). Direct comparison of water quality results from well 121 with time-equivalent data from wells 67 or 123 therefore may be misleading if one assumes that the different lithostratigraphic completion intervals could represent separate hydrogeochemical regimes.

Depth-specific ground water sampling is needed throughout the ICPP monitoring well network to determine the extent to which vertical geochemical variability actually exists under current hydrologic conditions. 


\section{CHAPTER 9}

\section{SUMMARY, CONCLUSIONS, AND RECOMMENDATIONS}

\section{Summary}

The upper portion of the Snake River Plain aquifer is both heterogeneous and anisotropic at the scale of the monitoring well network at the ICPP area. Meaningful spatial correlations of distinct hydrostratigraphic units (i.e., aquifers) are difficult to establish between the majority of these wells based on zvailable hydrogeologic data. Flow top units, which are believed to represent the primary high permeability pathways for ground water flow, appear to be spatially discontinuous based on caliper logs and do not correlate strictly with identified lithostratigraphic contacts within the upper portion of the aquifer.

Tracejector results indicate that the hydraulic interconnection and spatial configuration of water-producing zones is extremely complex. Intrawell ground water flow observed in selected monitoring wells shows no spatially recurring pattern at the scale of the ICPP area. Flow may be upwards, downwards, horizontal, or nonexistent depending on the specific depth and well location under consideration. Zones of ground water inflow and outflow do not appear to be strictly controlled by the basalt flow group contacts as defined by Anderson (1991). These data demonstrate that the upper portion of the Snake River Plain aquifer has a high degree of heterogeneity at the scale of the ICPP area. These observations suggest that the aquifer system is best described by a heterogeneous, anisotropic conceptual model in which both the magnitude and direction of hydraulic conductivity vectors are spatially dependent. 


\section{General Conclusions}

The upper portion of the Snake River Plain aquifer system at the scale of the existing ICPP monitoring network may be best described conceptually as a heterogeneous, anisotropic hydrogeologic system. This conclusion is based on a review of available hydrologic and geologic data, with greatest analysis given to the studies by Jones (1961), Anderson (1991), and Barraclough et al. (1967a). Limited spatial agreement exists between the aquifers defined by the hydrostratigraphic conceptual model of Jones (1961) and the lithostratigraphic conceptual model of Anderson (1991). Intrawell ground water flow measured by Barraclough et al. (1967a) cannot be explained by our current knowledge of basalt stratigraphy utilizing either of these conceptual models. The author concludes that the upper portion of the Snake River Plain aquifer acts as a heterogeneous, anisotropic system at the scale of the monitoring well network considered in this study. Additional data collection involving depth-specific, quantitative, hydrogeologic, hydraulic, and hydrogeochemical analyses will be necessary to better understand the occurrence and movement of ground water both within individual wells and at the scale of the ICPP area as a whole.

\section{Specific Conclusions}

1. The hydrostratigraphic correlation methods of Jones (1961) cannot be used alone to define the spatial distribution of discrete water-bearing intervals within or between the post-1960 wells at the ICPP. Jones's correlation techniques are not uniformly applicable to wells completed using markedly different drilling technologies, such as cable tool and air rotary methods. These correlation methods are flawed by a lack of consideration of quantifiable material properties, such as hydraulic conductivity, porosity, 
and/or bulk density, which are typically used to physically describe a unique hydrostratigraphic unit (Seaber, 1988).

2. Borehole enlargements shown on caliper logs cannot be strictly correlated with geologic contacts between the basalt flow groups identified by Anderson (1991). Delineated flow group contacts commonly cause little or no hole dianneter enlargement within selected uncased boreholes penetrating the upper portion of the Snake River Plain aquifer system. Similarly, borehole enlargements commonly occur within the interiors of identified basalt flow groups which are believed to be comprised of only one flow unit. These observations suggest that the basalt flow group contacts may not be the primary aquifer zones or that flow contacts are not described adequately using currently available geophysical logs or geologic data.

3. Geologic contacts between the basalt flow groups as defined by Anderson (1991) uncommonly occur at the same depth as the water-producing zones defined by downhole Tracejector tests. This implies that significant aquifer intervals do not everywhere correlate with the currently recognized interflow zones; they may occur within intraflow fracture sets or at currently unrecognized basalt flow contacts. State-of-thescience flow meter testing is necessary to determine the location, magnitude, and direction of current intrawell ground water flow (without the influence of fluid injection at well CPP3) but with the disposal ponds.

4. Most ICPP monitoring wells are currently equipped to sample ground water only from the upper lithostratigraphic intervals of the Snake River Plain aquifer, primarily basalt flow groups $\mathrm{E}, \mathrm{EF}$, and F. Upgradient monitoring well 121 is instrumented to sampie ground waier from approximately the same elevation in the aquifer as many downgradient wells, but is completed in flow group I. Two monitoring wells are currently sampled from composite stratigraphic unit DE6-DE8. Depth-specific hydrogeochemical sampling and analysis are necessary to determine if ground water quality varies 
significantly between different lithostratigraphic units adjacent to dedicated sampling pumps.

\section{Recommendations}

The following research program is recommended to provide the basis for a more descriptive hydrogeologic conceptual model of the upper portion of the Snake River Plain aquifer beneath the ICPP.

Phase I - Geologic Characterization:

1. Downhole television and/or acoustic televiewer logs should be run to visually identify and characterize fractured or vesicular basalt intervals and to determine if individual basalt flow units and/or flow group contacts (after Anderson, 1991) are recognizable at depth.

2. Gamma-gamma and neutron probes should be calibrated for borehole diameter effects prior to additional logging so that radioactive logs can be quantitatively and comparatively analyzed for formation density and porosity. Once properly calibrated, these logs may aid in defining distinct hydrostratigraphic units based on these quantifiable physical properties.

3. Core holes should be drilled and sampled adjacent to a number of existing ICPP wells previously drilled by both cable tool and air rotary methods. Core samples should be analyzed for lithologic, petrographic, paleomagnetic and geochronologic properties as discussed by Anderson (1991). These data should be incorporated into the existing lithostratigraphic mode!. 
Phase II - Hydrologic Characterization:

1. A sensitive flowmeter should be used to measure vertical ground water flow conditions with respect to the results of Phase I recommendations and the lithostratigraphic interpretations of Anderson (1991). Purnping conditions within ICPP production wells should be documented during each flowmeter logging event to determine if these hydraulic stresses influence intrawell ground water flow.

2. Temperature and fluid resistivity logs should be run to identify and/or confirm zones of preferential ground water movement at the scale of individual monitoring wells under current site conditions.

3. Based on the evaluation of the above data, straddle-packer experiments should be run to determine the relative hydraulic head distribution within each geologic interval and/or aquifer zone encountered in selected boreholes. These data will be useful for determining patterns of interaquifer flow and the potential for solute mixing between head zones. Vertical profiling of hydraulic conductivity within and between aquifers should also be attempted in selected monitoring wells.

4. Based on the results of the above testing, depth-specific ground water quality samples should be collected and analyzed within representative boreholes. These data should be used to determine if identifiable and traceable water chemistries or constituents can be correlated with hydrologic and stratigraphic data within and between wells. The geochemical significance of these results should also be evaluated with respect to the scale of the entire contaminant plume and the drinking water standards for the constituents of concerm.

Phase III - integrated Analysis ô Data:

An integrated analysis of additional data from the ICPP monitoring wells should be completed. This analysis should include consideration of the hydrostratigraphic analysis approach included in this study along with the aquifer transmissivity data described by Ackerman (1991), historical water quality data, and historical water level data. 


\section{REFERENCES CITED}

Ackerman, D., J., 1991. Transmissivity of the Snake River Plain aquifer at the Idaho National Engineering Laboratory, Idaho, IDO-22097, Water-Resources Investigation Report $91-4058$, U. S. Geological Survey, Idaho Falls, ID, 35 p.

Anderson, S. R., 1990. A preliminary geohydrologic evaluation of basalt and sediment underlying the Snake River Plain at the Idaho National Engineering Laboratory. In Abstracts of the Geological Society of America; Cordilleran Section $86^{\text {th }}$ Annual Meeting, vol. 22, no. 3, pp. 3.

Anderson, S, R., 1991. Stratigraphy of the unsaturated zone and uppermost part of the Snake River Plain aquifer at the Idaho Chemical Processing Plant and Test Reactors Area, Idaho National Engineering Laboratory, Idaho, IDO-22095, WaterResources Investigation Report 91-4010, U. S. Geological Survey, Idaho Falls, ID, $71 \mathrm{p}$.

Anderson, S. R., and R. C. Bartholomay, 1990. Use of natural gamma logs correlated to potassium-oxide content in determining the stratigraphy of basalt and sediment at the Idaho National Engineering Laboratory: Geological Society of America, Abstracts with Program, 43rd Annual Meeting, Rocky Mountain Section, v. 22, no. 6, p. 1 .

Bagby, J. C., L. J. White, and R. J. Jensen, 1984. Groundwater Site Inventory Data for Selected Wells at the Idaho National Engineering Laboratory, 1949 through 1982. IDO-22064, Open-File Report 84-231, U. S. Geological Survey, Idaho Falls, ID, $353 \mathrm{p}$.

Bagby, J. C., L. J. White, and R. J. Jensen, 1985. Water-quality for selected wells on or near the Idaho National Engineering Laboratory, 1949 through 1982. DDO-22068, Open-File Report 84-714, U. S. Geological Survey, Idaho Falls, ID, 800 p.

Barraclough, J. T., B. D. Lewis and R. G. Jensen, 1981. Hydrologic conditions at the Idaho National Engineering Laboratory, Idaho Emphasis: 1974-1978. IDO-22060, Open-File Report 81-526, U. S. Geological Survey, Idaho Falls, ID, 116 p.

Barraclough, J. T., J. B. Robertson, V. J. Janzer, 1976a. Hydrogeology. of the solid waste burial ground, as related to the potential migration of radionuclides, in Saindon, L. G. (ed.), Idaho National Engineering Laboratory, with a section on drilling and sampling analyses, IDO-22056, U. S. Geological Survey Open-File Report 76-471, 183 p.

Barraclough, J. T., and R. G. Jensen, 1976b. Hydrologic data for the Idaho National Engineering Laboratory Site, Idaho, DC-22055, U. S. Geolozical Surve; OpenFile Report 76-318, 51 p.

Barraclough, J. T., J. C. Bagby, L. J. White, and R. G. Jensen, 1984. Water-Level Data for Selected Wells on or Near the Idaho National Engineering Laboratory, 1949 through 1982. IDO-22065, Open-File Report 84-239, U. S. Geological Survey, Idaho Falls, D, 343 p. 
Barraclough, J. T., W. E. Teasdale, and R. G. Jensen, 1967a. Hydrology of the National Reactor Testing Station, Idaho: Annual Progress Report, 1965, IDO-22048, OpenFile Report, U. S. Geological Survey, Idaho Falls, ID, 107 p.

Barraclough, J. T., W. E. Teasdale, J. B. Robertson, and R. G. Jensen, $1967 \mathrm{~b}$. Hydrology of the National Reactor Testing Station, Idaho, 1966, IDO-22049, Open-File Report, U. S. Geological Survey, Idaho Falls, ID, 95 p.

Bartholomay, R. C., 1990. Digitized Geophysical Logs for Selected Wells on or Near the Idaho National Engineering Laboratory, Idaho. IDO-22088, Open-File Report 90366, U. S. Geological Survey, Idaho Falls, ID, 347 p.

Bartholomay, R. C., L. L. Knobel, and L. C. Davis, 1989. Mineralogy and Grain Size of Surficial Sediment from the Big Lost River Drainage and Vicinity, with Chemical and Physical Characteristics of Geologic Materials from Selected Sites at the Idaho National Engineering Laboratory, Idaho. IDO-22081, Open-File Report 89-384, U. S. Geological Survey, Idaho Falls, ID, 74 p.

Chase, C. H., W. E. Teasdale, D. A. Ralston, and R. G. Jensen, 1964. Observation Wells 1 through $49,51,54,55,56,80$ and 81 at the National Reactor Testing Station, Idaho, IDO-22045, U. S. Geological Survey, Idaho Falls, ID, 147 p.

Doherty, D. J., L. A. McBroome, M. A. Kuntz, 1979. Preliminary geological interpretation and lithologic log of the Exploratory Geothermal Test Well (INEL-1), Idaho National Engineering Laboratory, eastern Snake River Plain, Idaho, IDO22079, Open-File Report 79-1248, U. S. Geological Survey, Idaho Falls, ID, 9 p.

Domenico, P. A., and F. W. Schwartz, 1990. Physical and Chemical Hydrogeology, Wiley and Sons, Inc., New/York, 824 p.

Driscoll, F. G., 1986, Groundwater and Wells, Johnson Division Inc., St. Paul, Minnesota, 1108 p.

Felix and Scisson, 1989. Report on perforation and cementing for abandonment of the ICPP injection well MAH-FE-PL-304, prepared for MK-Ferguson of Idaho Co., Boise, ID, 15 p.

Freeze, R. A., J. Cherry, 1979. Groundwater, Prentice-Hall publishing Co., Englewood Cliffs, NJ, 604 p.

Golder Associates Inc., 1990. Well completion report for weils 121, 122 and 123 at the Idaho Chemical Processing Plant, Ref: C86-131159, Task 6, Redmond/Richland, Washington. Prepared for EG\&G Idaho, Inc./Westinghouse Idaho Nuclear Corporation, Idaho Falls, ID, 35 p. plus tables and figures.

Goldstein, F. J., and W. D. Weight, 1992. Subsurface information from eight wells drilled at the Idaho National Engineering Laboratory, southeastem Idaho, IDO22063, Open-File Report 82-644, U. S. Geological Survey, Idaho Falls, ID, 29 p.

Hackett, B., Pelton, J., and Brockway, C., 1986. Geohydrologic story of the eastern Snake River Plain and the Idaho National Engineering Laboratory, U. S. Department of Energy publication BP-455-1186-2.5M-A, 32 p. 
Hull, L. C., 1987. Hydrogeologic Assessment of Land Disposal Unit, CPP-37 ICPP Gravel Pit \#2, EG\&G Idaho, Inc. Hydrology Unit, Idaho National Engineering Laboratory, 46 p. plus Appendices.

Idaho Water Resources Research Institute (IWRRI), 1991. Compilation report of monitoring well completion data for the Idaho Chemical Processing Plant, Idaho National Engineering Laboratory, unpublished report, IWRRI library, UI office, Moscow, ID.

Jones, J. R., and P. T. Voegeli, 1950. Geology and Ground Water at Site 7, Reactor Testing Station, Idaho, IDO-22000, U. S. Geological Survey, Boise, ID, 27 p.

Jones, J. R., and S. L. Jones, 1952. Logs of Water Wells, Reactor Testing Station, Idaho, IDO-22013, U. S. Geological Survey, Boise, ID, 38 p.

Jones, P. H., 1961. Hydrology of Waste Disposal National Reactor Testing Station, Idaho, An Interim Report, IDO-22042, U. S. Geological Survey, Idaho Falls, ID, 82 p. plus Figures.

Keys, W. W., 1963. Drilling, casing, and cementing observation wells at the National Reactor Testing Station, Idaho, U. S. Atomic Energy Commission, Idaho Operations Office Publication, IDO-12022, 42 p.

Keys, W. W., 1989. Borehole geophysics applied to ground water investigations, published by NWWA, Dublin, OH, 313 p.

King, J. S., 1977. Regional setting of the Snake River Plain, Idaho, in Greeley, R. and King, J. S. (ed.), Volcanism of the eastern Snake River Plain, Idaho: NASA, Washington, D.C., p. 46-57.

Knutson, C. F., K. A. McCormick, R. P. Smith, W. R. Hackett, J. P. O'Brien, J. C. Crocker, 1990. FY 89 Report -- RWMC vadose zone basalt characterization (Informal report), EGG-WM-8949, Prepared for U. S. DOE by EG\&G of Idaho, Idaho Falls, Idaho, 126 p. plus 4 Appendices.

Kuntz, M. A. and G. B. Dalrymple, 1979. Geology, geochronology, and potential volcanic hazards in the Lava Ridge-Hells Half Acre area, eastern Snake River Plain, Idaho. Open-File Report 79-1657, U. S. Geological Survey, Idaho Falls, ID, 66 p.

Kuntz, M. A., G. B. Dalrymple, G. B. Champion, D. J. Doherty, 1980. Perrography, age, and paleomagnetism of volcanic rocks at the Radioactive Waste Management Complex, Idaho National Engineering Laboratory, Idaho, with an evaluation of potential volcanic hazards. Open-File Report 80-388, U. S. Geological Survey, Idaho Falls, ID, 63 p.

Lewis, B. D., and R. G. Jensen, 1984. Hydrologic Conditions at the Idaho National Engineering Laboratory, Idaho, IDO-22066, Open-File Report 84-230, U. S. Geological Survey, Idaho Falls, ID, 65 p.

Lewis, B. D., J. M. Eagleton, and R. G. Jensen, 1985. Aqueous Radioactive- and Industrial-Waste Disposal at the Idaho National Engineering Laboratory Through 1982, IDO-22069, Open-File Report 84-636, U. S. Geological Survey, Idaho Falls, ID, 77 p. 
Lewis, D. L. and F. J. Goldstein, 1982. Evaluation of a Predictive Ground-Water Solute Transport Model at the Idaho National Engineering Laboratory, Idaho, IDO-22062, Water-Resource Investigation report 82-25, U. S. Geological Survey, Idaho Falls, ID, 71 p.

Lindholm, G. F., and J. J. Vaccaro, 1988. Region 2, Columbia Lava Plateau, In Back, W., J. S. Rosenshein, and P. R. Seaber (ed.), 1988, Hydrogeology. The Geology of North America, Vol. 0-2, GSA DNAG Publication, 524 p. plus plates.

Luttrell, S. P., 1982. Ground-water flow characteristics in the Mud Lake area, southeastern Idaho, M. S. thesis, University of Idaho, Dept. of Geology and Geological Engineering, 69 p.

Maxey, G. B., 1964. Hydrostratigraphic units: Journal of Hydrology, volume 2, p. 124129

Mann, L. J., 1986. Hydraulic properties of rock units and chemical quality of water from INEL-1 -- A 10,365-foot deep test hole drilled at the Idaho National Engineering Laboratory, Idaho. IDO-22070, Open-File Report 86-4020, U. S. Geological Survey, Idaho Falls, ID, 23 p.

Mann, L. J., 1989. Tritium concentrations in flow from selected springs that discharge to the Snake River, Twin Falls-Hagerman area, Idaho, IDO-22085, Water-Resources Investigations report 89-4156, U. S. Geological Survey, Idaho Falls, ID, 20 p.

Mann, L. J., 1990. Purgeable organic compounds in ground water at the Idaho National Engineering Laboratory, Idaho, DO-22089, Open-File Report 90-367, U. S. Geological Survey, Idaho Falls, ID,

Mann, L. J., and L. D. Cecil, 1990. Tritium in ground water at the Idaho National Engineering Laboratory, Idaho, IDO-22090, Water-Resources Investigations report 90-4090, U. S. Geological Survey, Idaho Falls, ID, 35 p.

Mann, L. J., and L. L. Knobel, 1987. Purgeable organic compounds in ground water at the Idaho National Engineering Laboratory, Idaho -- 1988-1989, IDO-22074, Open-File Report 87-766, U. S. Geological Survey, Idaho Falls, ID.

Mann, L. J., and L. L. Knobel, 1988. Concentrations of nine trace metals in ground water at the Idaho National Engineering Laboratory, Idaho, DO-22075, Open-File Report 88-332, U. S. Geological Survey, Idaho Falls, ID.

Morris, D. A. and others, 1963. Hydrology of the Waste Disposal National Reactor Testing Station, Idaho, Annual Progress Report - 1962, IDO-22044, U. S. Geological Survey, Idaho Falls, ID, 99 p.

Morris, D. A., and others, 1965. Hydrology of the Subsurface Waste Disposal National Reactor Testing Station, Idaho, Annual Progress Report - 1964, DO-22047, U. S. Geological Survey, Idaho Falls, ID, 147 p.

Morris, D. A., W. E. Teasdale and others, 1964. Hydrology of the Subsurface Waste Disposal National Reactor Testing Station, Idaho, Annual Progress Report - 1963, IDO-22046, U. S. Geological Survey, Idaho Falls, ID, 97 p. 
Mundorff, M. J., E. G. Crosthwaite, and C. Kilburn, 1964. Ground water for irrigation in the Snake River basin in Idaho, U. S. Geological Survey Water-Supply Paper $1654,224 \mathrm{p}$.

Nace, R. L., and J. W. Stewart, 1951. Memorandum Report on Results of Pumping Tests on CPP Production Well No. 1, Atomic Energy Commission Reactor Testing Station, Idaho, IDO-22011, U. S. Geological Survey, Boise, ID, 6 p. plus figures.

Nace, R. L., Deutsch, Morris, and Voegeli, 1956. Geography, Geology and Water Resources of the National Reactor Testing Station, Idaho, Part 2: Geology and geography, IDO-22033, U. S. Geological Survey, Boise, D, 225 p.

Nace, R. L., J. W. Stewart, W. C. Walton and others, 1959. Geography, Geology and Water Resources of the National Reactor Testing Station, Idaho, Part 3: Hydrology and Water Resources, IDO-22034, U. S. Geological Survey, Boise, ID, 253 p.

Nace, R. L., P. T. Voegeli, J. R. Jones and M. Deustch, 1975. Generalized geologic framework of the National Reactor Testing Station, Idaho, U. S. Geological Survey Professional Paper 725-B, 49 p.

Nielson, D. M., 1991. Practical Handbook of Ground Water Monitoring, published by NWWA, Dublin, OH.

North American Commission on Stratigraphic Nomenclature (NACSN), 1983. North American Stratigraphic Code: American Association of Petroleum Geologists Bulletin, 67(5), p. 841-875.

Olmstead, F. H., 1962. Chemical and Physical Character of Ground Water in the National Reactor Testing Station, Idaho, IDO-22043, U. S. Geological Survey, Boise, ID, $81 \mathrm{p}$. plus tables and figures.

Peckham, A. E., 1959. Investigation of Underground Waste Disposal, Chemical Processing Plant Area, National Reactor Testing Station, Idaho, DO-22039, U. S. Grological Survey, Boise, ID, 35 p.

Pittman, J. R. 1989. Hydrologic and Meteorologic Data for an Unsaturated Zone study near the Radioactive Waste Management Complex, Idaho National Engineering Laboratory, Idaho--1985-86, IDO-22079, Open-File Report 89-74, U. S. Geological Survey, Idaho Falls, ID, 175 p.

Pittman, J. R., R. G. Jensen, and P. R. Fisciner, 1988. Hydrologic Conditions at the Idaho National Engineering Laboratory, 1982 to 1985 , DO-22078, WaterResources Investigations Report 89-4008, U. S. Geological Survey, Idaho Falls, $\mathrm{ID}, 73 \mathrm{p}$.

Robertson, J. B., 1974. Digital modeling of radioactive and chemica' waste transport in the Snake River Plain aquifer at the National Reactor Testing Station, Idaho, DO22057, Open-File Report 76-717, U. S. Geological Survey, Idaho Falls, ID, 68 p.

Robertson, J. B., and J. T. Barraclough, 1973. Radioactive- and chemical-waste transport in ground water at the National Reactor Testing Station, Idaho: 20-year case history, and digital model, AAPG Underground Waste Management and Artificial Recharge, Volume 1, p. 291-322. 
Robertson, J. B., R. Schoen, and J. T. Barraclough, 1974. The Influence of Liquid Waste Disposal on the Geochemistry of Water at the National Reactor Testing Station, Idaho, 1952-1970, IDO-22053, Open-File Report, U. S. Geological Survey, Idaho Falls, ID, 231 p.

Scalf, M. R., J. F. McNabb, W. J. Dunlap, R. L. Crosby, J. Fryberger, 1981. Manual of ground-water sampling procedures, NWWA/EPA series, published by NWWA, Dublin, $\mathrm{OH}, 93$. p.

Seaber, P.R., 1986. Evaluation of classification and nomenclature of hydrostratigraphic units; EOS Transactions of the American Geophysical Union, 67(16), p. 281.

Seaber, P.R., 1988. Hydrostratigraphic units, In Back, W., J. S. Rosenshein, and P. R. Seaber (ed.), 1988, Hydrogeology. The Geology of North America, Vol. 0-2, GSA DNAG Publication, 524 p. plus plates.

U. S. Department of Energy, 1990a. Comprehensive Well Survey of the Idaho National Engineering Laboratory, DOE/LD-10300, Volumes I-III, Prepared by EG\&G of Idaho, Idaho Falls, Idaho, 759 p. plus plates.

U. S. Department of Energy, 1990b. Closure plan for LDU CPP-23 injection well (MAHFE-PL-304), prepared by WINCO, Inc., Idaho Falls, D, 66 p.

U. S. Department of Environmental Protection, 1985. Practical guide to ground-water sampling, U. S. EPA, Ada, OK, EPA/600/2-85-104, 169 p.

Walker, E. H., 1964. Subsurface geology of the National Reactor Testing Station, Idaho, U. S. Geological Survey Bulletin 1133-E, 22 p.

Walker, E. H., 1960, Analysis of Aquifer Tests, January 1958-June 1959, at the National Reactor Testing Station, Idaho, IDO-22040, U. S. Geological Survey, Boise, ID, $40 \mathrm{p}$.

Walton, W. C., 1958. Analysis of Aquifer Tests at the National Reactor Testing Station, Idaho: 1949-1957, DO-22034, U. S. Geological Survey, Boise, ID, 32 p.

Whitehead, R. L., 1986. Geohydrologic framework of the Snake River Plain, Idaho and eastern Oregon, U. S. Geological Survey Hydrologic Investigations Atlas HA-681, 3 sheets.

Wood, W. W., and L. A. Fernandez, 1988. Comparative Hydrogeology; Volcanic rocks, In Back, W., J. S. Rosenshein, and P. R. Seaber (ed.), 1988, Hydrogeology. The Geology of North America, Vol. 0-2, GSA DNAG Publication, 524 p. plus plates. 


\section{APPENDIX 1.}

Drillers' logs, geophysical logs, and geologic interpretations

for selected ICPP monitoring wells 


\section{DRILLERS' LOGS FOR SELECTED 100-SERIES MONITORING WELLS}

(See Table 3, p. 31 for well completion details)

\section{USGS WELL 111}

Depth (feet, bgs)

$\begin{array}{rcl}\begin{array}{c}\text { from } \\ \text { fo }\end{array} & \frac{10}{12} & \text { Description of Formation } \\ 12 & 35 & \text { Gravel and dirt } \\ 35 & 47 & \text { Clay } \\ 47 & 160 & \text { Basalt } \\ 160 & 170 & \text { Broken } \\ 170 & 260 & \text { Basalt } \\ 260 & 268 & \text { Broken and soft } \\ 268 & 365 & \text { Basalt } \\ 385 & 395 & \text { Soft } \\ 395 & 425 & \text { Basalt } \\ 425 & 441 & \text { Clay } \\ 441 & 600 & \text { Basalt } \\ 600 & & \text { Bottom of hole }\end{array}$

Notes: Data compiled from well drillers' shift log by Denning Well Drilling, Inc., Ucon, Idaho Well drilled on August 21, 1984

\section{USGS WELL 112}

Depth (feet, bgs)

$\begin{array}{rr}\text { from } & \text { to } \\ 0 & 30 \\ 30 & 80 \\ 80 & 90 \\ 90 & 110 \\ 110 & 120 \\ 120 & 130 \\ 130 & 135 \\ 135 & 150 \\ 150 & 15 i \\ 151 & 173 \\ 173 & 181 \\ 181 & 203 \\ 203 & 205 \\ 205 & 220 \\ 220 & 400 \\ 400 & 405 \\ 405 & 415 \\ 415 & 416\end{array}$

Description of Formation
Clay-basait
Lava
Broken lava
Lava
Loose rock
Lava
Clay
Lava
Broken
Lava
Soft clay
Lava
Clay
Lava
Lava
Clay
Lava
Broken

\begin{tabular}{|c|c|c|}
\hline & \\
\hline & $\begin{array}{l}\text { Depth (feet, bgs) } \\
\text { from to }\end{array}$ & Descriotion of Formation \\
\hline 416 & 420 & Lava \\
\hline 420 & 425 & Clay \\
\hline 425 & 432 & Lava \\
\hline 432 & 435 & Broken clay \\
\hline 435 & 445 & Lava \\
\hline 445 & 446 & Crevices \\
\hline 446 & 475 & Lava \\
\hline 475 & 480 & Broken \\
\hline 480 & 484 & Clay \\
\hline 484 & 495 & Lava \\
\hline 495 & 498 & Broken \\
\hline 498 & 500 & Lava \\
\hline 500 & 503 & Crevices \\
\hline 503 & 510 & Lava \\
\hline 510 & 511 & Broken \\
\hline 511 & 558 & Lava \\
\hline 558 & 560 & Broken \\
\hline 560 & & Bottom of hole \\
\hline
\end{tabular}

Notes: Data compiled from well drillers' shift log by Denning Well Drilling, Inc., Ucon, Idaho Well drilled on August 21, 1984 


\section{DRILLERS' LOGS FOR SELECTED 100-SERIES MONITORING WELLS (Continued)}

(See Table 3, p. 31 for well completion details)

\begin{tabular}{ccl}
$\begin{array}{c}\text { USGS WELL 113 } \\
\text { Depth (feet, bgs) } \\
\text { from }\end{array}$ & \\
\hline 0 & 10 & Description of Formation \\
12 & 38 & Sand, gravel, and dirt \\
38 & 42 & Basalt \\
42 & 55 & Bay \\
55 & 58 & Clay \\
58 & 127 & Basalt \\
127 & 130 & Clay \\
130 & 173 & Basalt \\
173 & 186 & Clay \\
186 & 355 & Basalt \\
355 & 363 & Soft \\
363 & 385 & Basalt \\
385 & 400 & Soft \\
400 & 560 & Basalt \\
560 & & Bottom of hole
\end{tabular}

Notes: Data compiled from well drillers' shift log by Denning Well Drilling, Inc., Ucon, Idaho Well drilled on September 3, 1984

USGS WELL 114

Depth (feet, bgs)

from to

$\begin{array}{rr}0 & 30 \\ 30 & 80\end{array}$

$80 \quad 90$

$90 \quad 110$

$110 \quad 120$

$120 \quad 130$

$130 \quad 135$

$135 \quad 150$

$150 \quad 151$

$151 \quad 173$

$173 \quad 181$

$181 \quad 203$

$203 \quad 205$

$205 \quad 220$

$220 \quad 400$

$400 \quad 405$

$405 \quad 415$

$415 \quad 416$

Rescription of Formation
Cliyy and gravel
Lava
Broken lava
Lava
Loose rock
Lava
Clay
Lava
Broken
Lava
Soft clay
Lava
Clay
Lava
Lava
Clay
Lava
Broken

\begin{tabular}{ccl}
$\begin{array}{c}\text { Depth (feet, bgs) } \\
\text { from }\end{array}$ & to & Description of Formation \\
\hline 416 & 420 & Lava \\
420 & 425 & Clay \\
425 & 432 & Lava \\
432 & 435 & Broken clay \\
435 & 445 & Lava \\
445 & 446 & Crevices \\
446 & 475 & Lava \\
475 & 480 & Broken \\
480 & 484 & Clay \\
484 & 495 & Lava \\
495 & 498 & Broken \\
498 & 500 & Lava \\
500 & 503 & Crevices \\
503 & 510 & Lava \\
510 & 511 & Broken \\
511 & 558 & Lava \\
558 & 560 & Broken \\
560 & & Bottom of hole
\end{tabular}

Notes: Data compiled from well drillers' shift log by Denning Well Drilling, Inc., Ucon, Idaho Well drilled in September, 1984

Static depth to water $=461$ feet bgs 
DRILLERS' LOGS FOR SELECTED 100-SERIES MONITORING WELLS (Continued)

(See Table 3, p. 31 for well completion details)

USGS WELL 115

Depth (feet, bgs)

$\begin{array}{rrl}\text { from } & \text { to } & \text { Description of Formation } \\ 0 & 22 & \text { Gravel } \\ 22 & 110 & \text { Basalt } \\ 110 & 160 & \text { Clay } \\ 160 & 330 & \text { Basalt } \\ 330 & 336 & \text { Clay } \\ 336 & 450 & \text { Basalt } \\ 450 & 460 & \text { Clay } \\ 460 & 555 & \text { Basalt } \\ 555 & 557 & \text { Clay } \\ 557 & 585 & \text { Basalt } \\ 585 & 600 & \text { Clay, sand, and gravel }\end{array}$

Notes: Data compiled from well drillers' shift log by Denning Well Drilling, Inc., Ucon, Idaho Well drilled on September 12, 1984

USGS WELL 116

Depth (feet, bgs)

$\begin{array}{rrl}\begin{aligned} \text { from } \\ 0\end{aligned} & \frac{\text { to }}{30} & \text { Description of Formation } \\ 30 & 108 & \text { Gravel and dirt } \\ 108 & 112 & \text { Basalt } \\ 112 & 125 & \text { Boft clay } \\ 125 & 135 & \text { Clay } \\ 135 & 215 & \text { Basalt } \\ 215 & 235 & \text { Broken basalt (caving) } \\ 235 & 267 & \text { Basalt } \\ 267 & 275 & \text { Soft } \\ 275 & 278 & \text { Broken } \\ 278 & 580 & \text { Basalt } \\ 580 & & \text { Gravel }\end{array}$

Notes: Data compiled from well drillers' shift log by Denning Well Drilling, Inc., Ucon, Idaho Well drilled from September 26 - October 5, 1984 

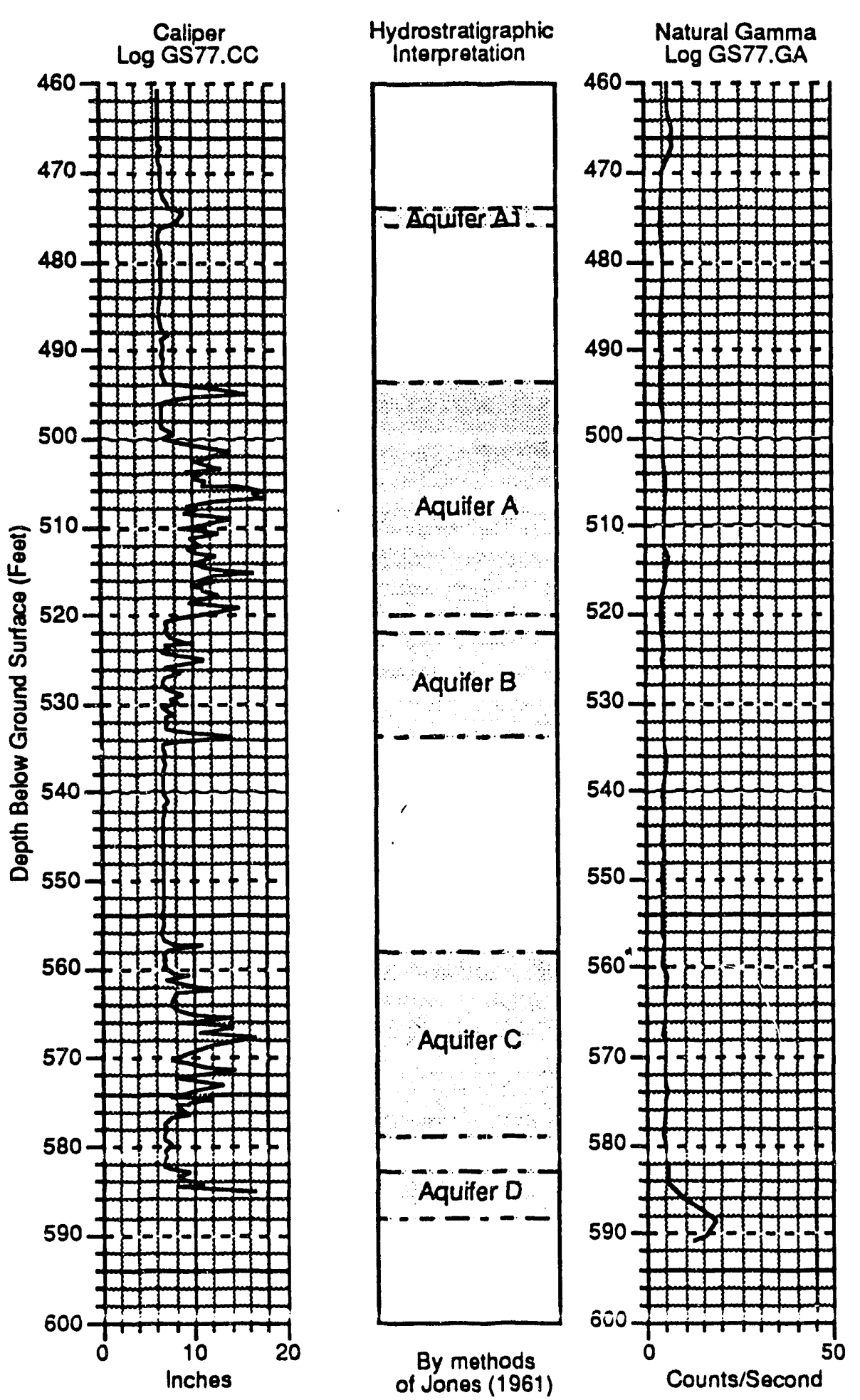

Lithostratigraphic
Interpretation

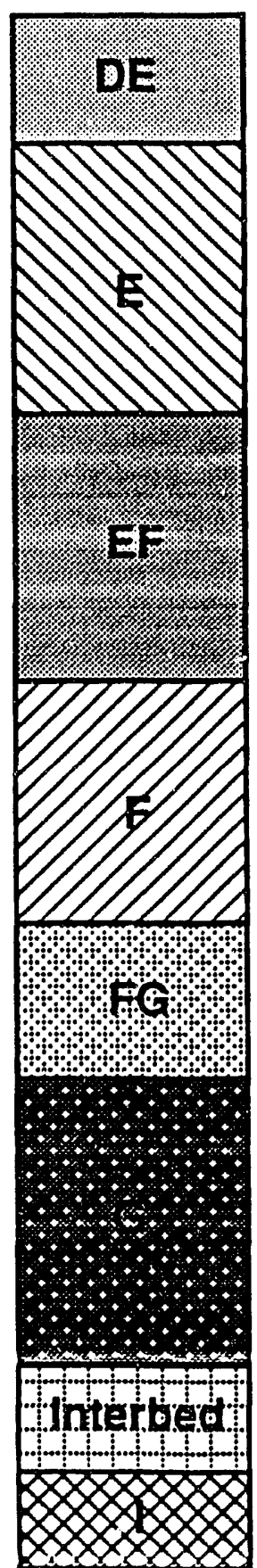

After Anderson

(1991)

Figure A1-1. Caliper and natural-gamma logs for Well 77 below the regional water table showing hydrostratigraphic units determined using the methods of Jones (1961). Lithostratigraphic units, as interpreted by Anderson (1991), are also shown. Reference elevation $=4923$ feet (MSL). 
Monitoring Well 111
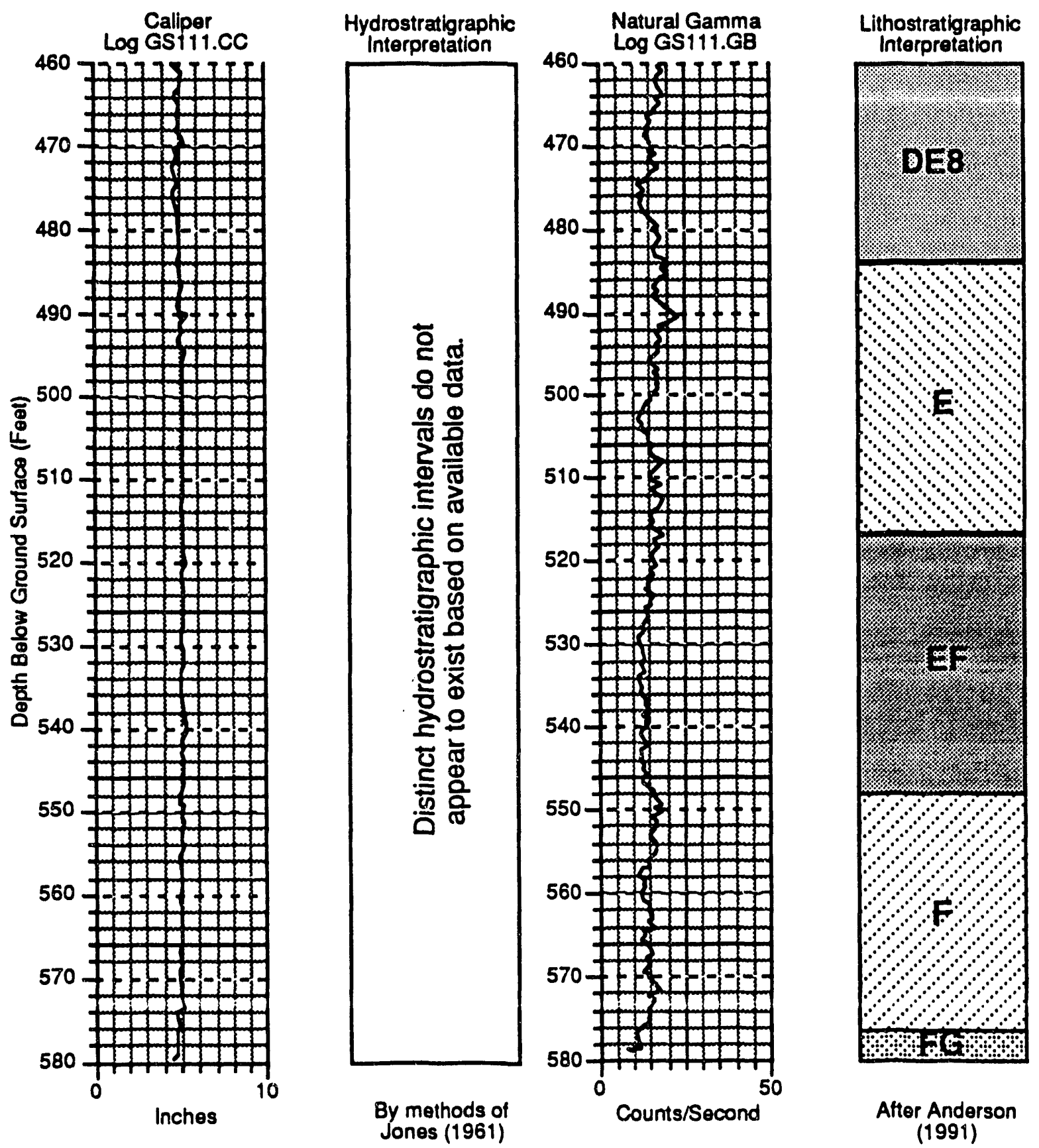

Figure A1-2. Caliper and natural-gamma logs for Well 111 below the regional water table showing hydrostratigraphic units determined using the methods of Jones (1961). Lithostratigraphic units, as interpreted by Anderson (1991), are also shown. Reference elevation $=4920$ feet (MSL). 
Monitoring Well 112
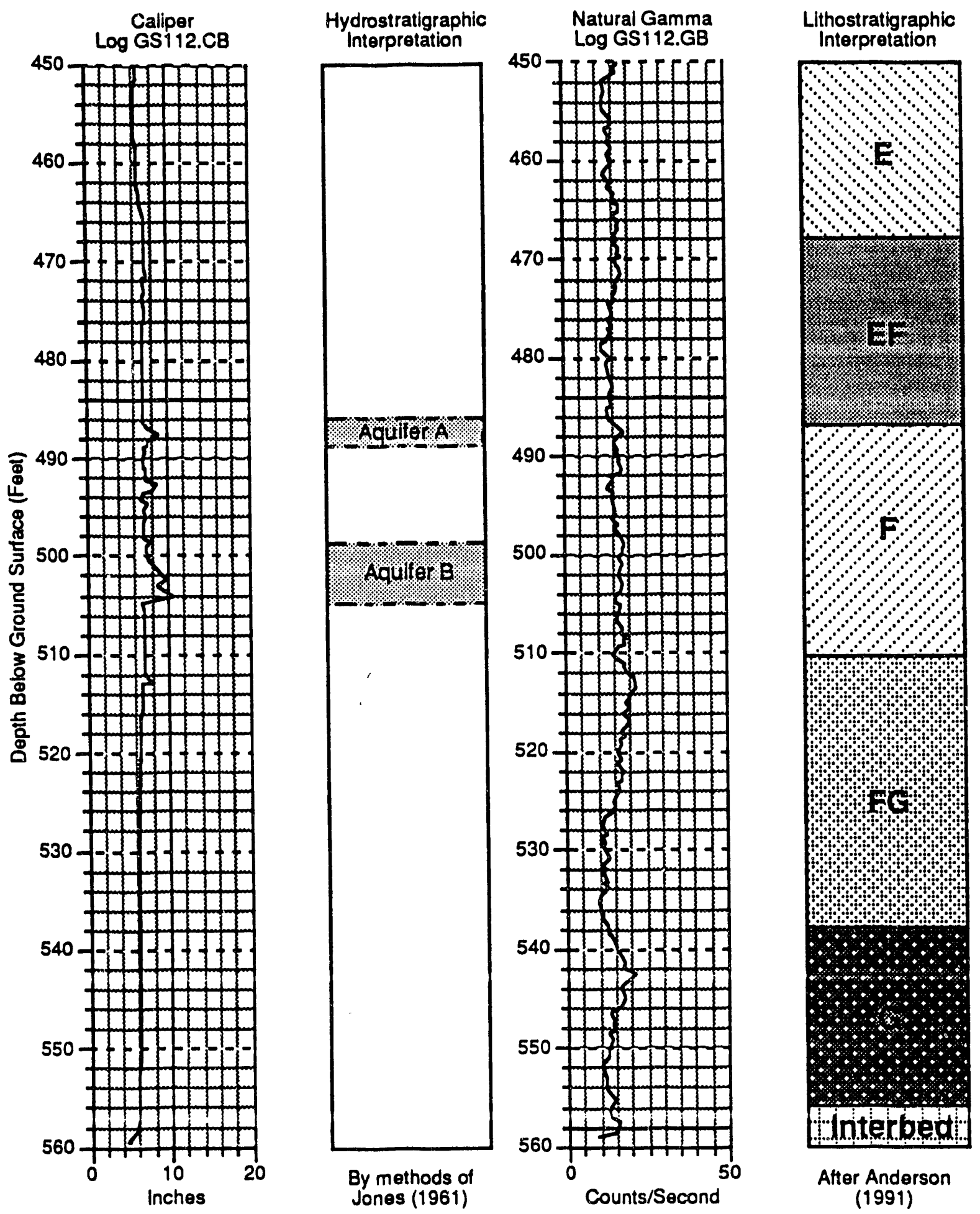

Figure A1-3. Caliper and natural-gamma logs for Well 112 below the regional water table showing hydrostratigraphic units determined using the methods of Jones (1961). Lithostratigraphic units, as interpreted by Anderson (1991), are also shown. Reference elevation $=4927$ feet $(M S L)$. 
Monitoring Well 113
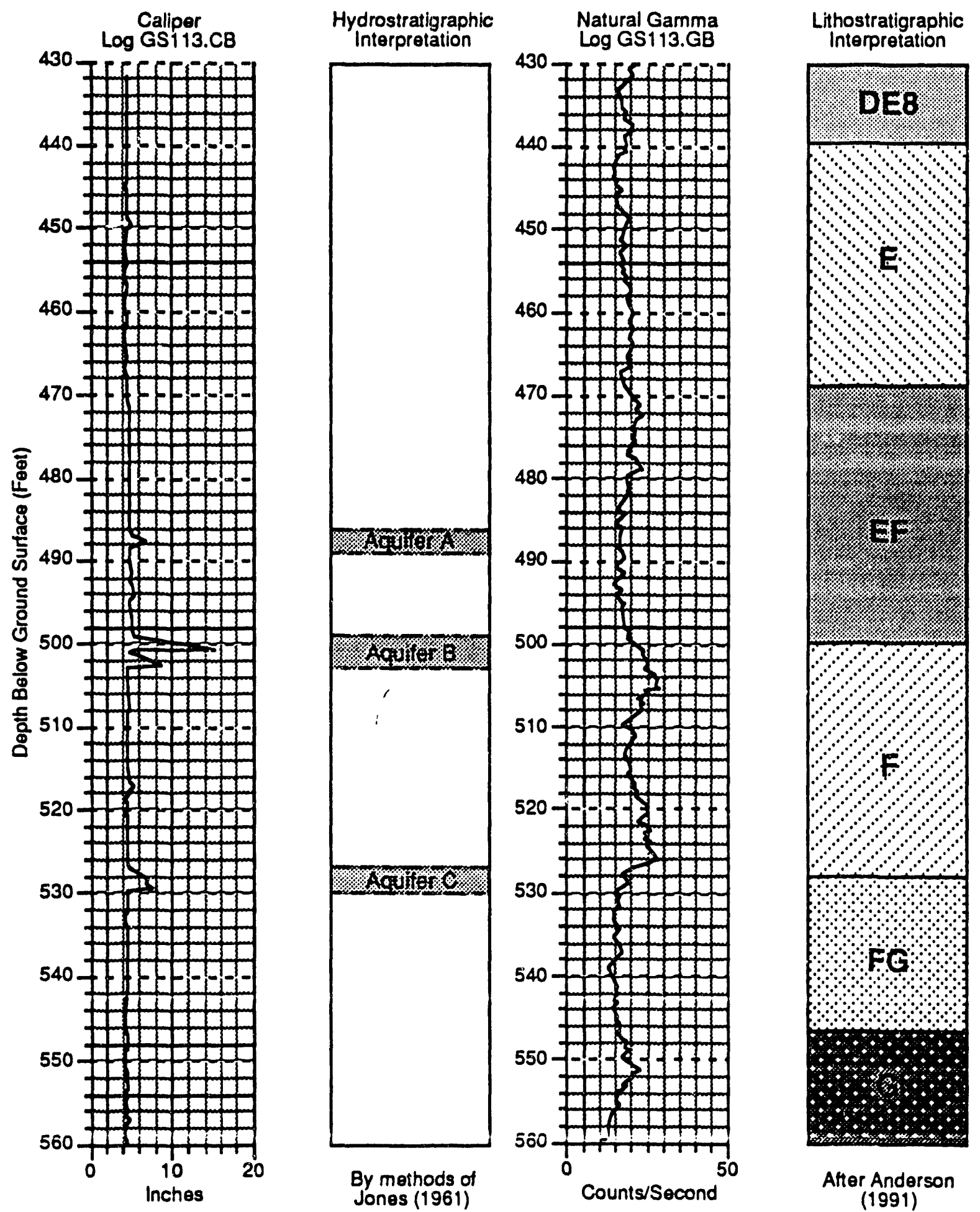

Figure A1-4. Caliper and natural-gamma logs for Well 113 below the regional water table showing hydrostratigraphic units determined using the methods of Jones (1961). Lithostratigraphic units, as interpreted by Anderson (1991), are also shown. Reference elevation $=4925$ feet (MSL). 


\section{Monitoring Well 114}

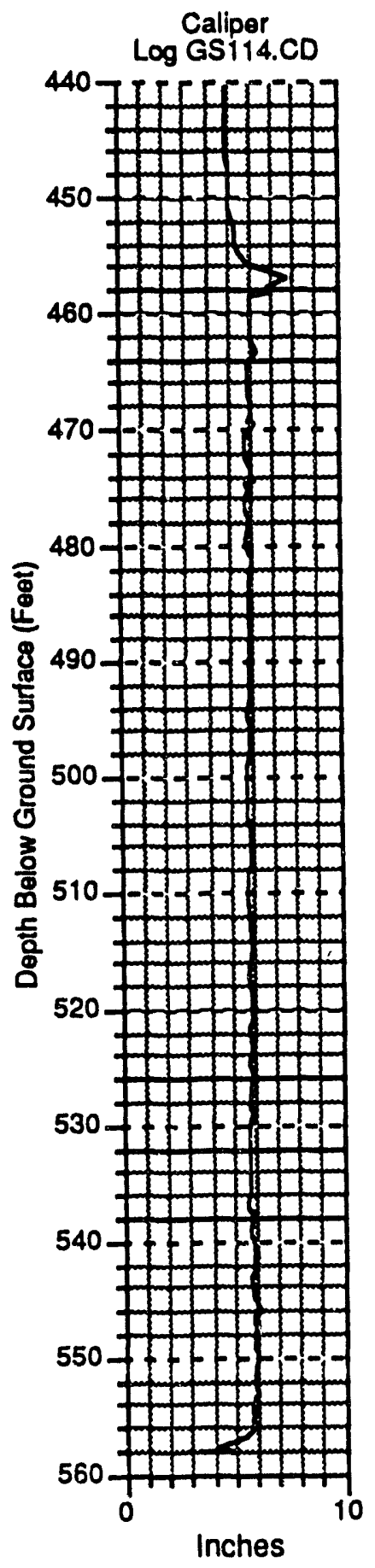

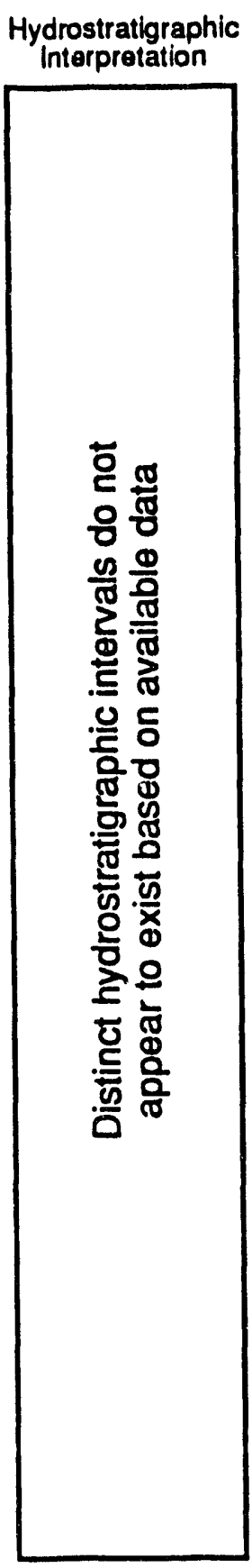

By methods of Jones (1961)
Lithostratigraphic Interpretation
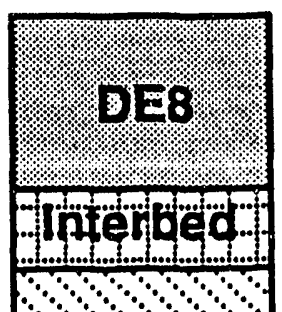

$\because \because \because$<smiles></smiles><smiles></smiles><smiles>C1#CCC#C1</smiles>

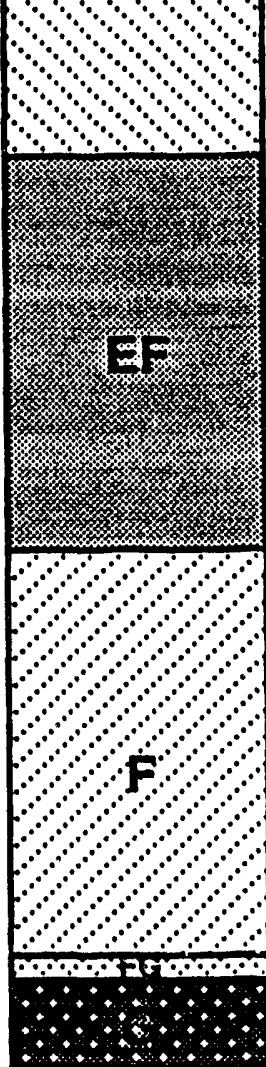

After Anderson (1991)

Note: Presentation of natural gamma data is not possible in this format because digitized log records do not exist.

Figure A1-5. Caliper and natural-gamma logs for Well 114 below the regional water table showing hydrostratigraphic units determined using the methods of Jones (1961). Lithostratigraphic units, as interpreted by Anderson (1991), are also shown. Reference elevation $=4920$ feet $(M S L)$. 


\section{Monitoring Well 115}

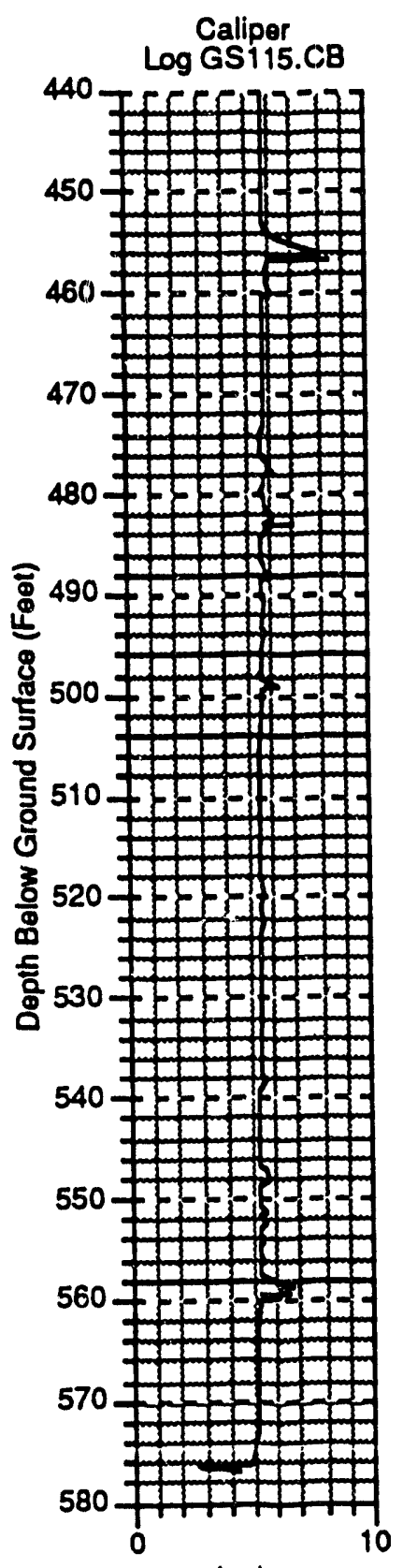

Inches

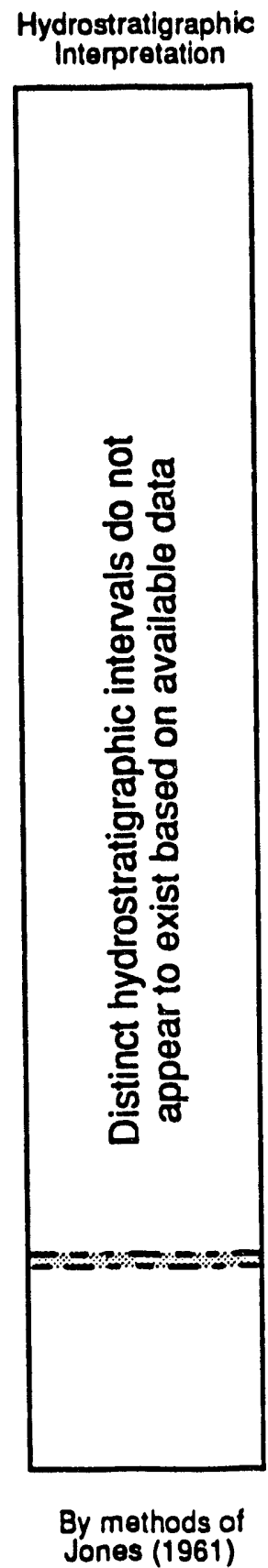

Lithostratigraphic Interpretation

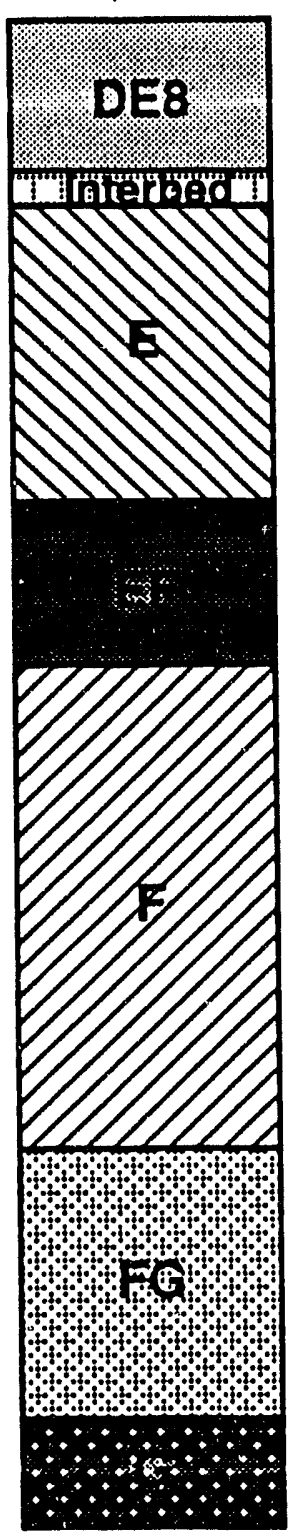

After Anderson (1991)

Note: Presentation of natural gamma data is not possible in this format because digitized log records do not exist.

Figure A1-6. Caliper and natural-gamma logs for Well 115 below the regional water table showing hydrostratigraphic units determined using the methods of Jones (1961). Lithostratigraphic units, as interpreted by Anderson (1991), are also shown. Reference elevation $=4919$ feet $(M S L)$. 
Monitoring Well 116
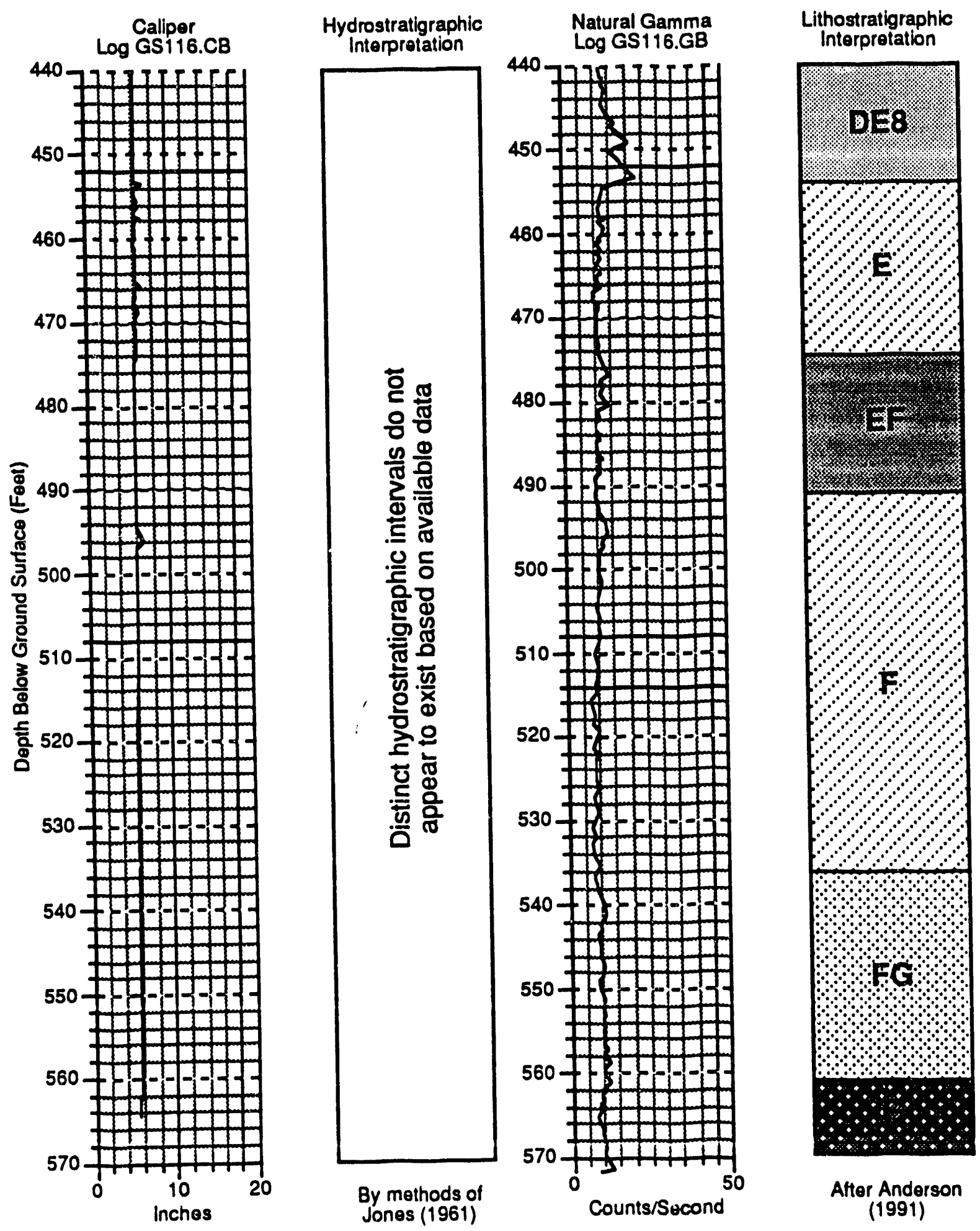

Figure A1-7. Caliper and natural-gamma logs for Well 116 below the regional water table showing hydrostratigraphic units determined using the methods of Jones (1961). Lithostratigraphic units, as interpreted by Anderson (1991), are also shown. Reference elevation $=4916$ feet (MSL). 

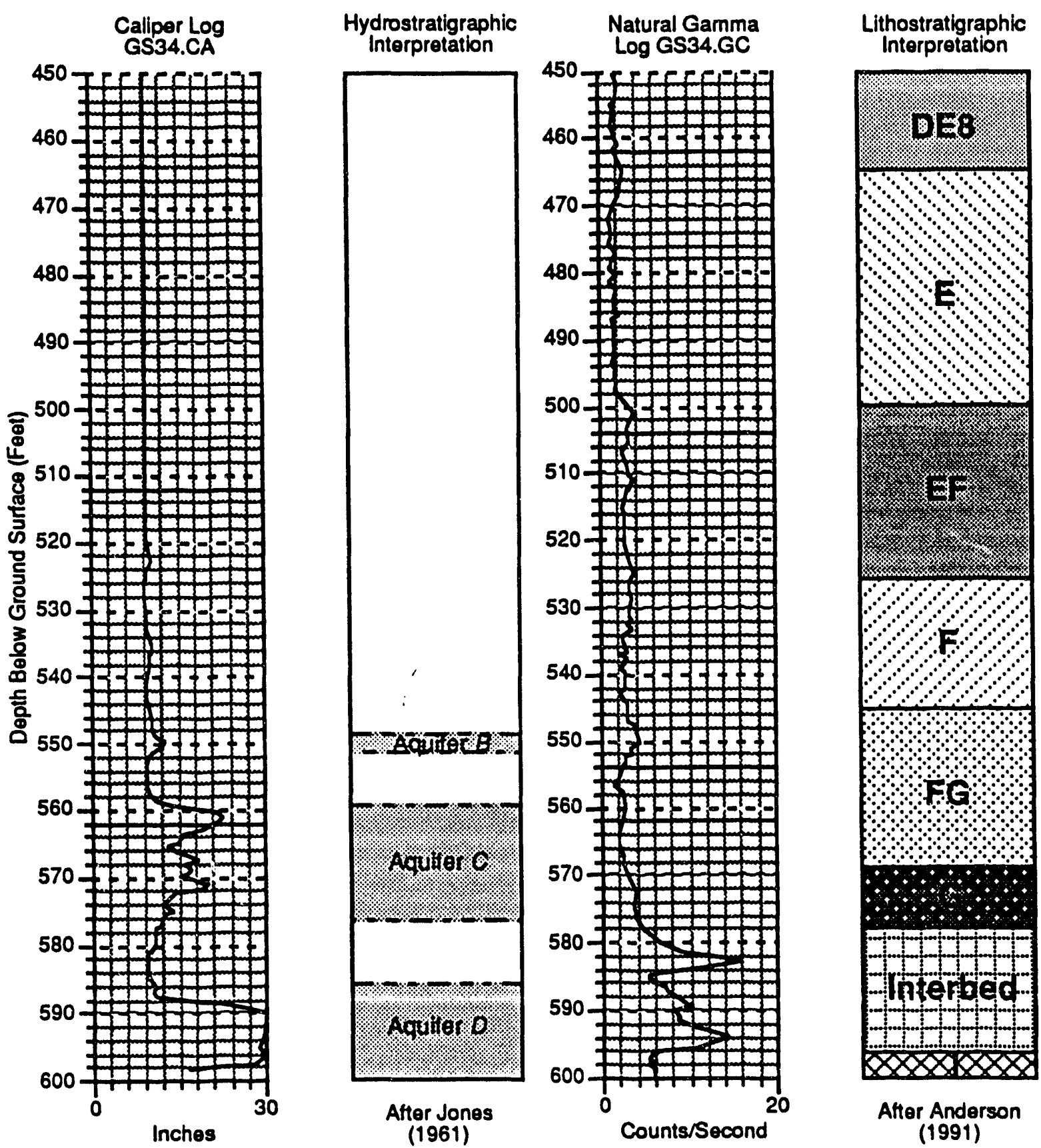

After Anderson (1991)

Figure A1-8. Caliper and natural-gamma logs for Well 34 below the regional water table showing hydrosiratigraphic units determined by Jones (1961). Lithostratigraphic units, as interpreted by Anderson (1991), are also shown. Reference elevation $=4929$ feet (MSL). 

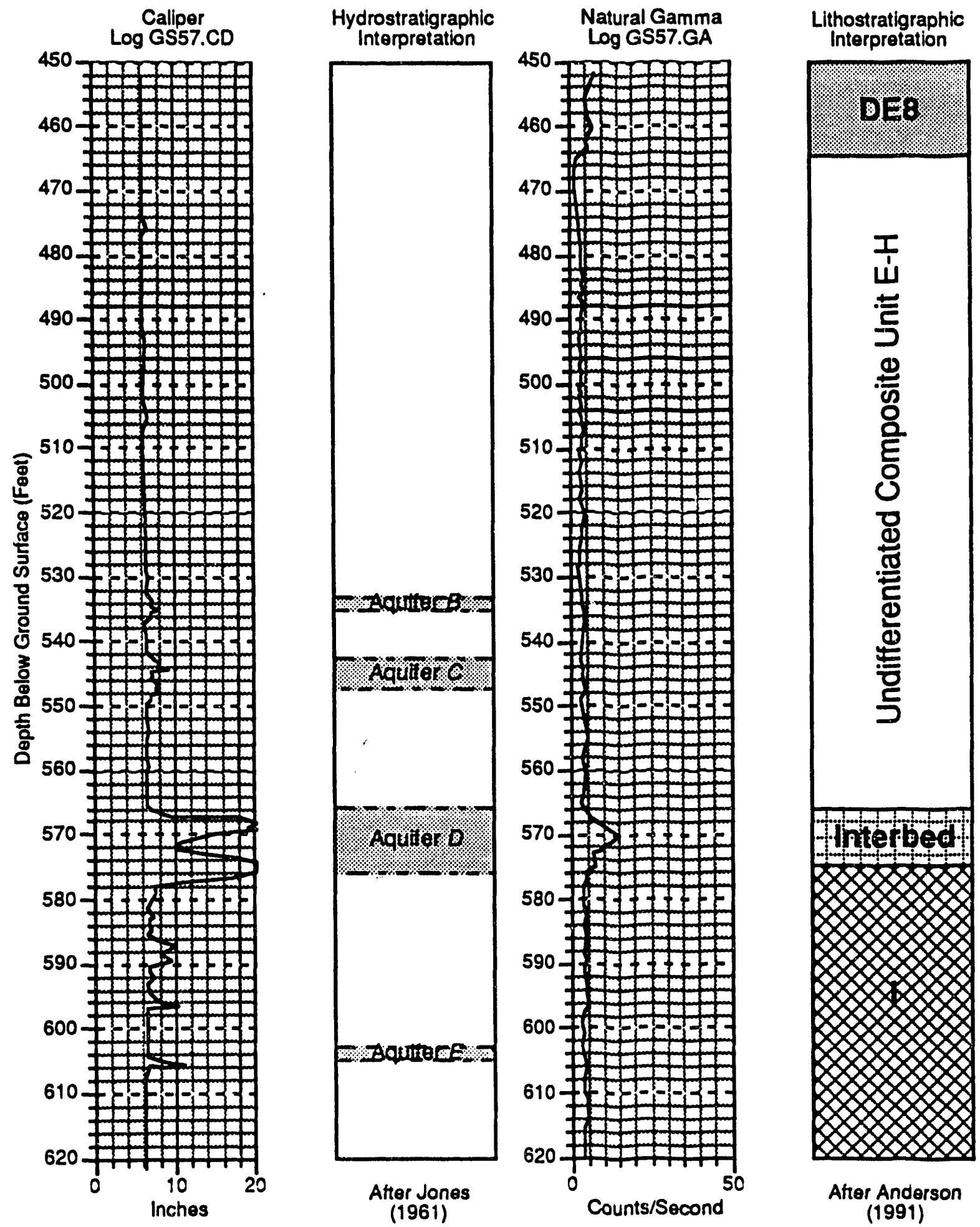

Figure A1-9. Caliper and natural-gamma logs for Well 57 below the regional water table showing hydrostratigraphic units determined by Jones (1961). Lithostratigraphic units, as interpreted by Anderson (1991), are also shown. Reference elevation $=4923$ feet (MSL). 


\section{Monitoring Well 51}
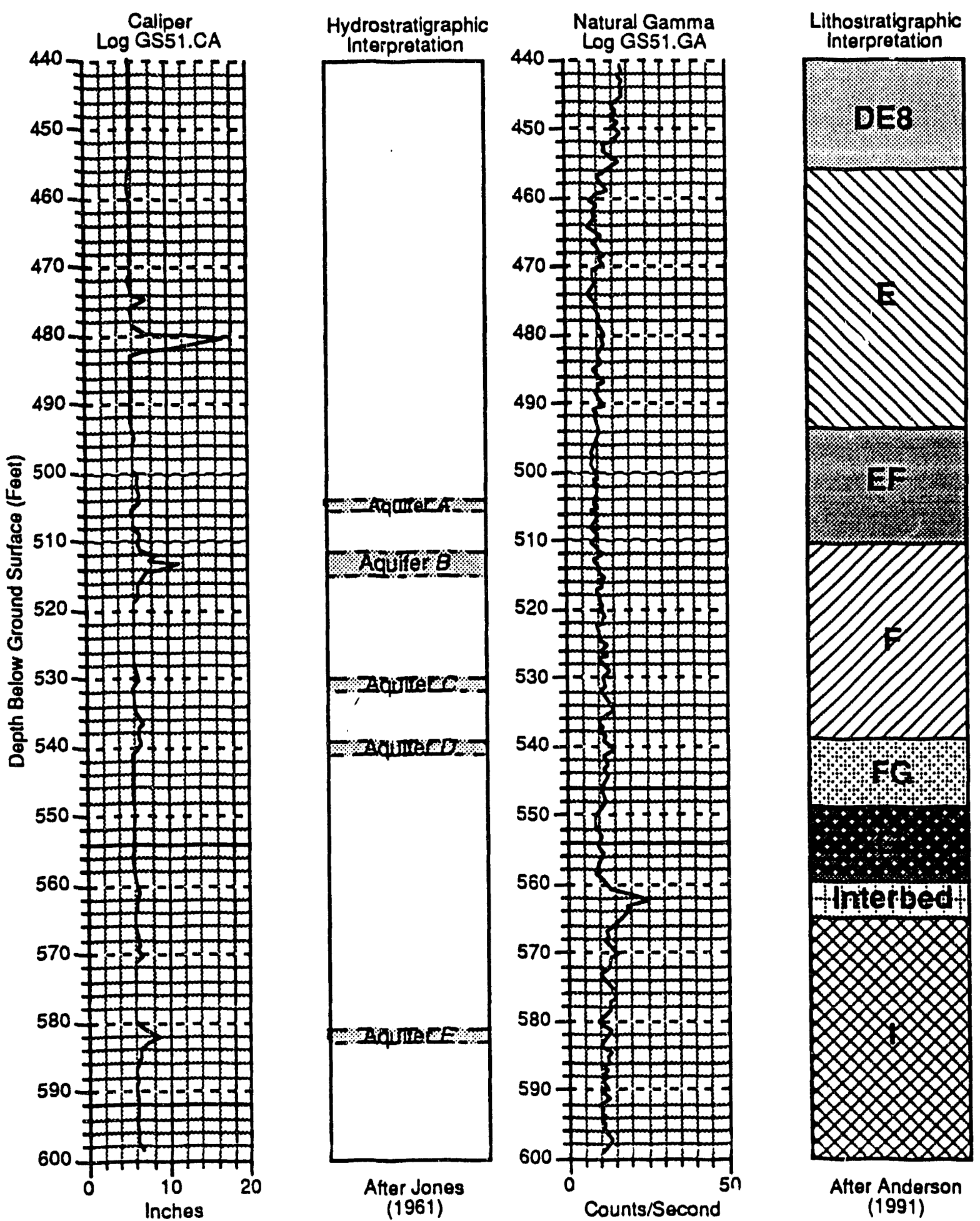

Figure A1-10. Caliper and natural-gamma logs for Well 51 below the regional water table showing hydrostratigraphic units determined by Jones (1961). Lithostratigraphic units, as interpreted by Anderson (1991), are also shown. Reference elevation $=4918$ feet (MSL). 


\section{Monitoring Well 67}
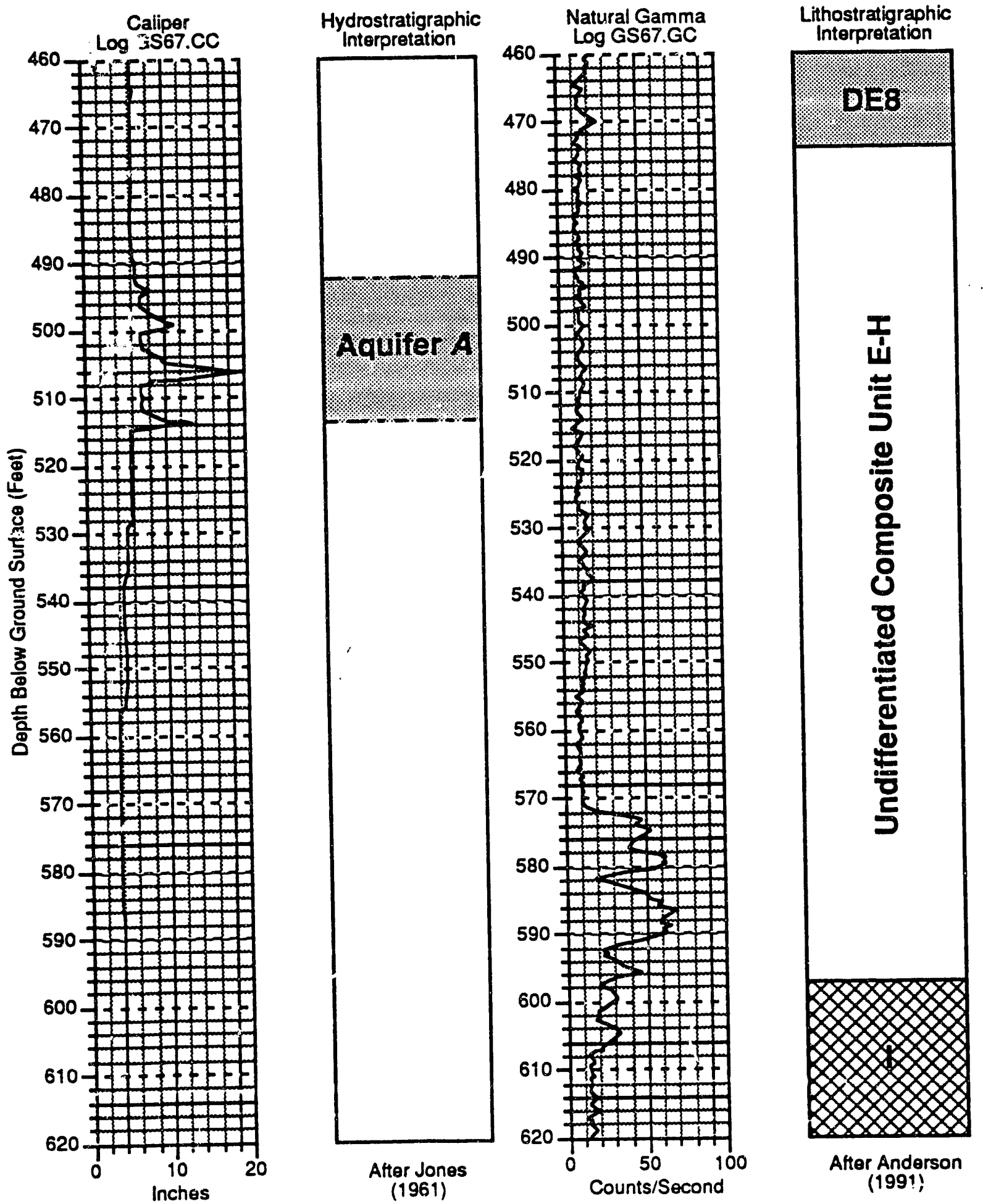

Figure A1-11. Caliper and natural-gamma logs for Well 67 below the regional water lable showing hydrostratigraphic units determined by Jones (1961). Lithostratigraphic units, as interpreled by Anderson (1991). are also snown. Reference elevation $=4916$ feet (MSL). 


\section{Monitoring Well 59}
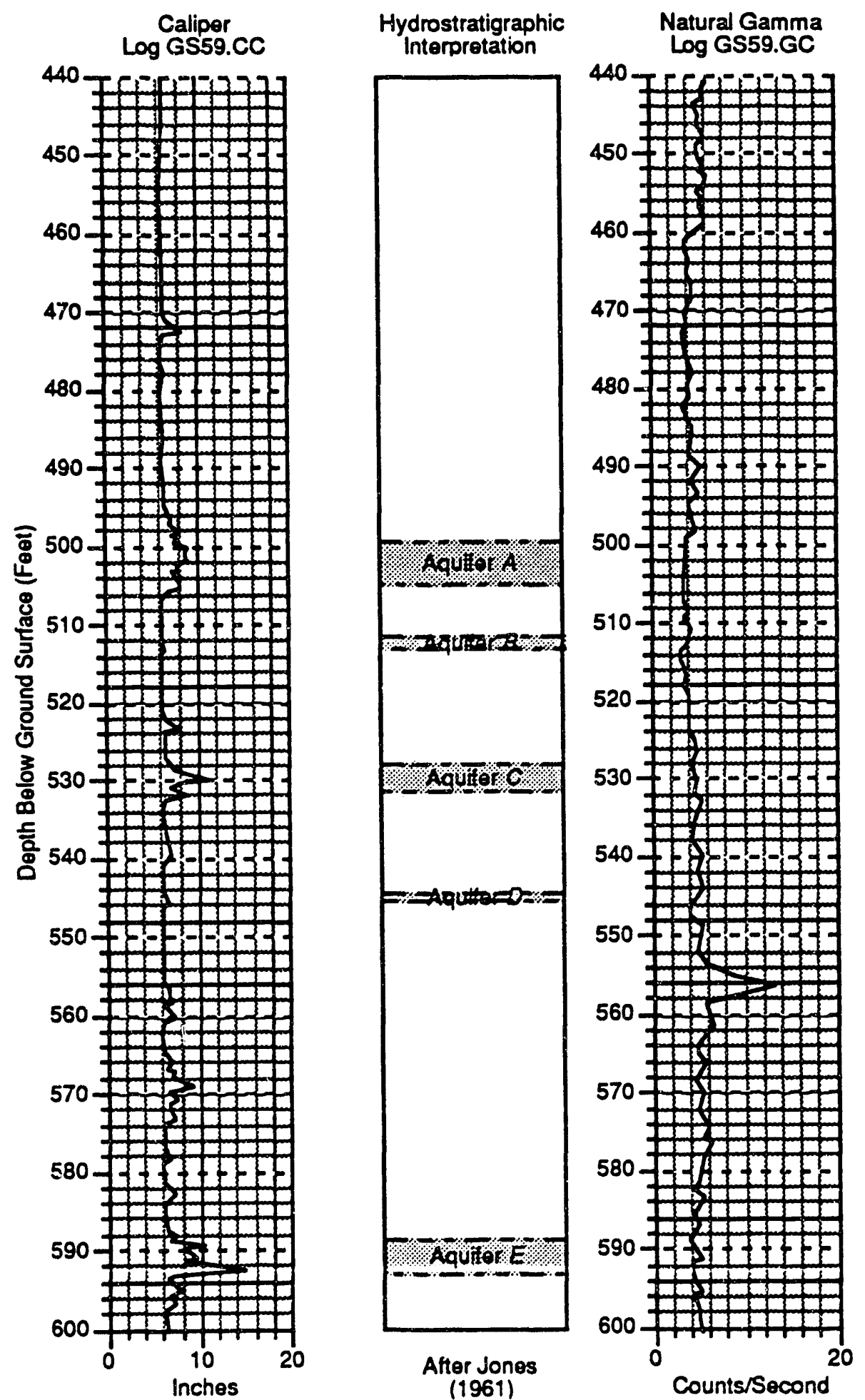

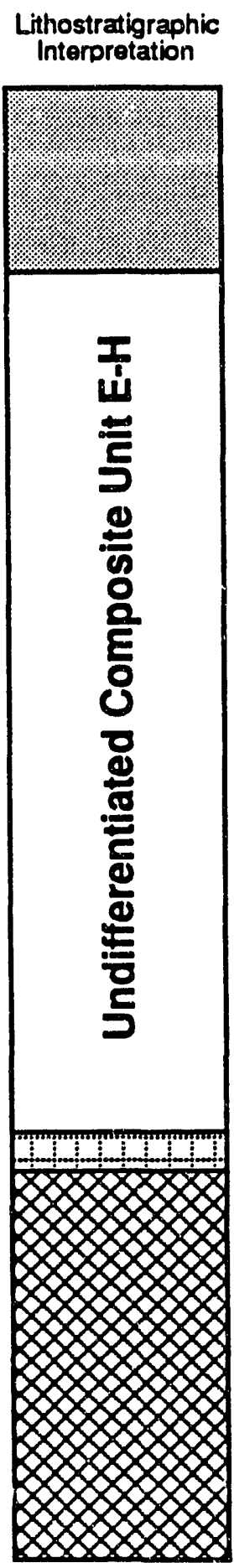

After Anderson (1991)

Figure A1-12. Caliper and natural-gamma logs for Well 59 below the regional water table showing hydrostratigraphic units determined by Jones (1961). Lithostratigraphic units, as interpreted by Anderson (1991), are also shown. Reference elevation $=4915$ feet (MSL). 


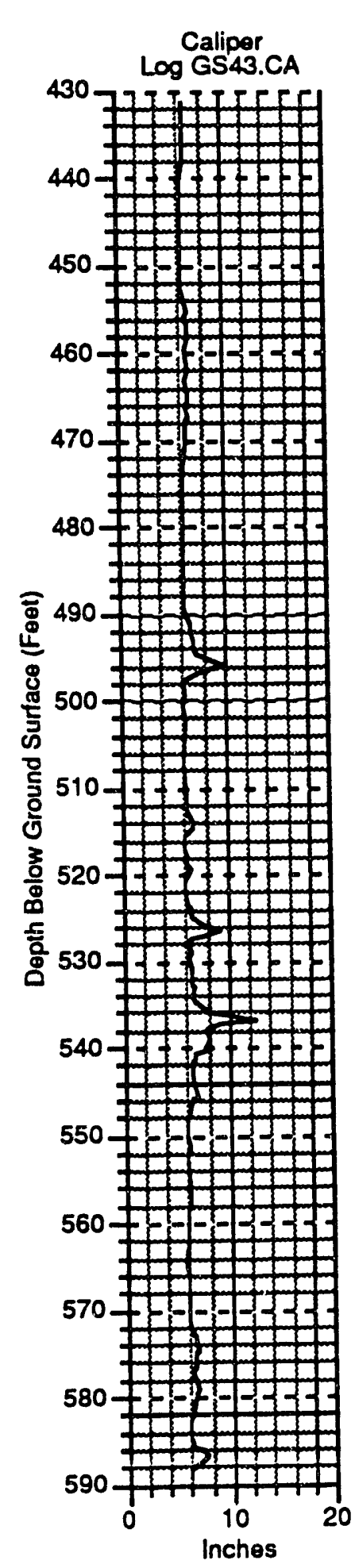

\section{Monitoring Well 43}

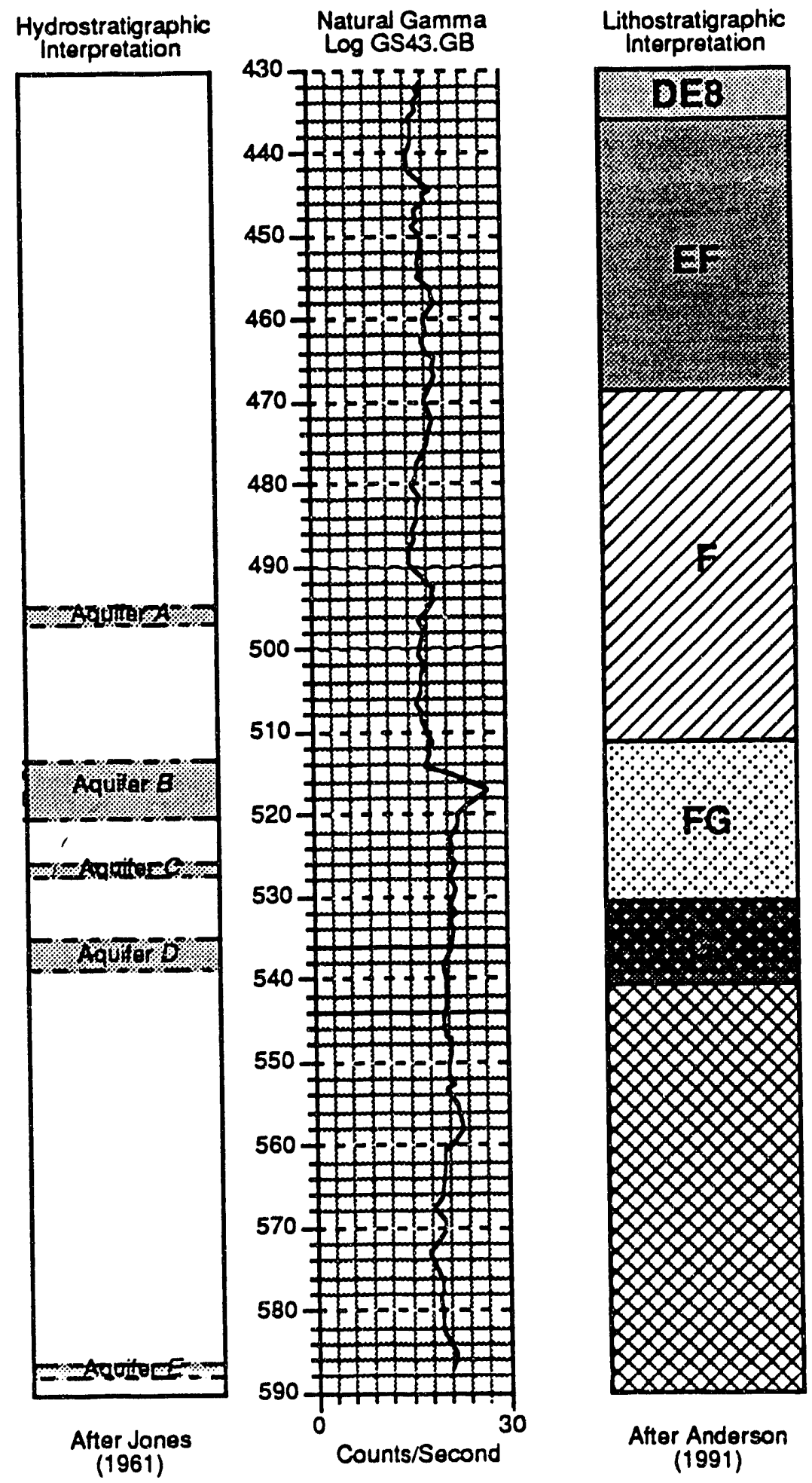

Figure A1-13. Caliper and natural-gamma logs for Well 43 below the regional water table showing hydrostratigraphic units determined by Jones (1961). Lithostratigraphic units, as interpreted by Anderson (1991), are also shown. Reference elevation $=4916$ feet $(M S L)$. 
Monitoring Well 47
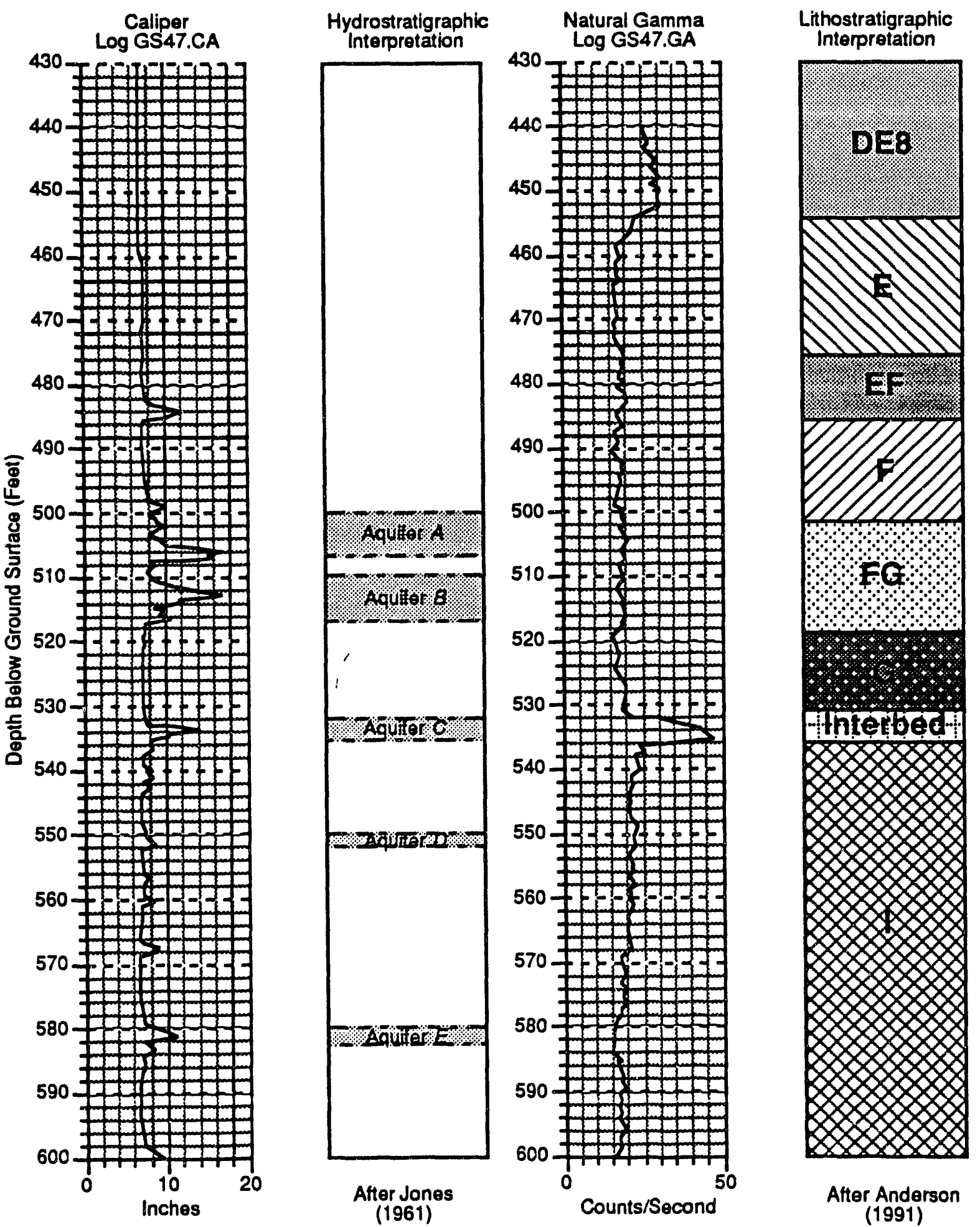

Figure A1-14. Caliper and natural-gamma logs for Well 47 below the regional water table showing hydrostratigraphic units determined by Jones (1961). Lithostratigraphic units, as interpreted by Anderson (1991), are also shown. Reference elevation $=4915$ feet (MSL). 
Monitoring Well 48
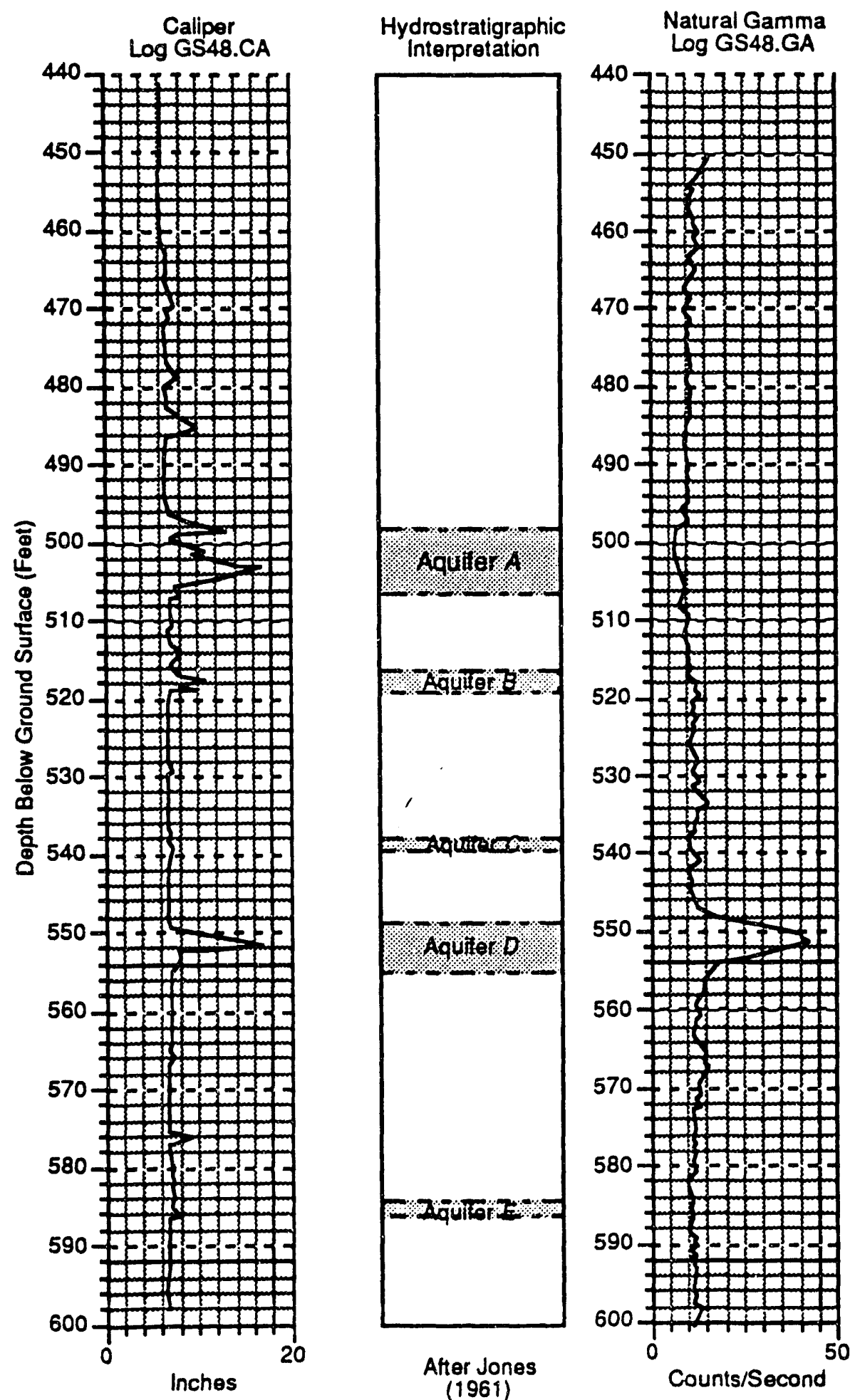

Lithostratigraphic
Interpretation
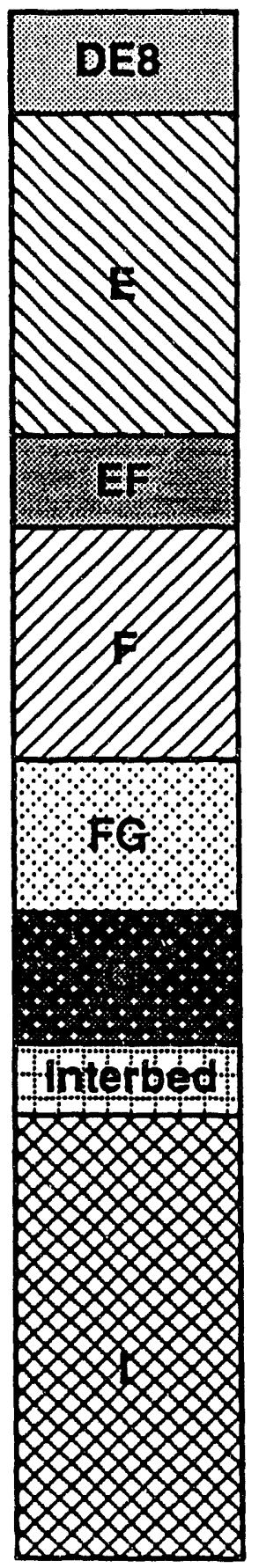

After Anderson (1991)

Figure A1-15. Caliper and natural-gamma logs for Well 48 below the regional water table showing hydrostratigraphic units determined by Jones (1961). Lithostratigraphic units, as interpreted by Anderson (1991), are also shown. Reference elevation $=4917$ feet (MSL). 


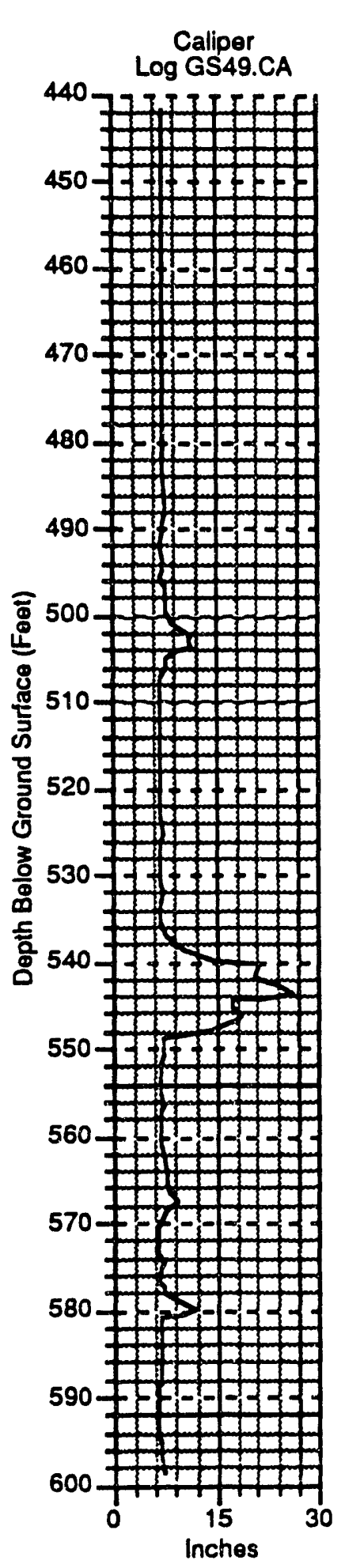

\section{Monitoring Well 49}
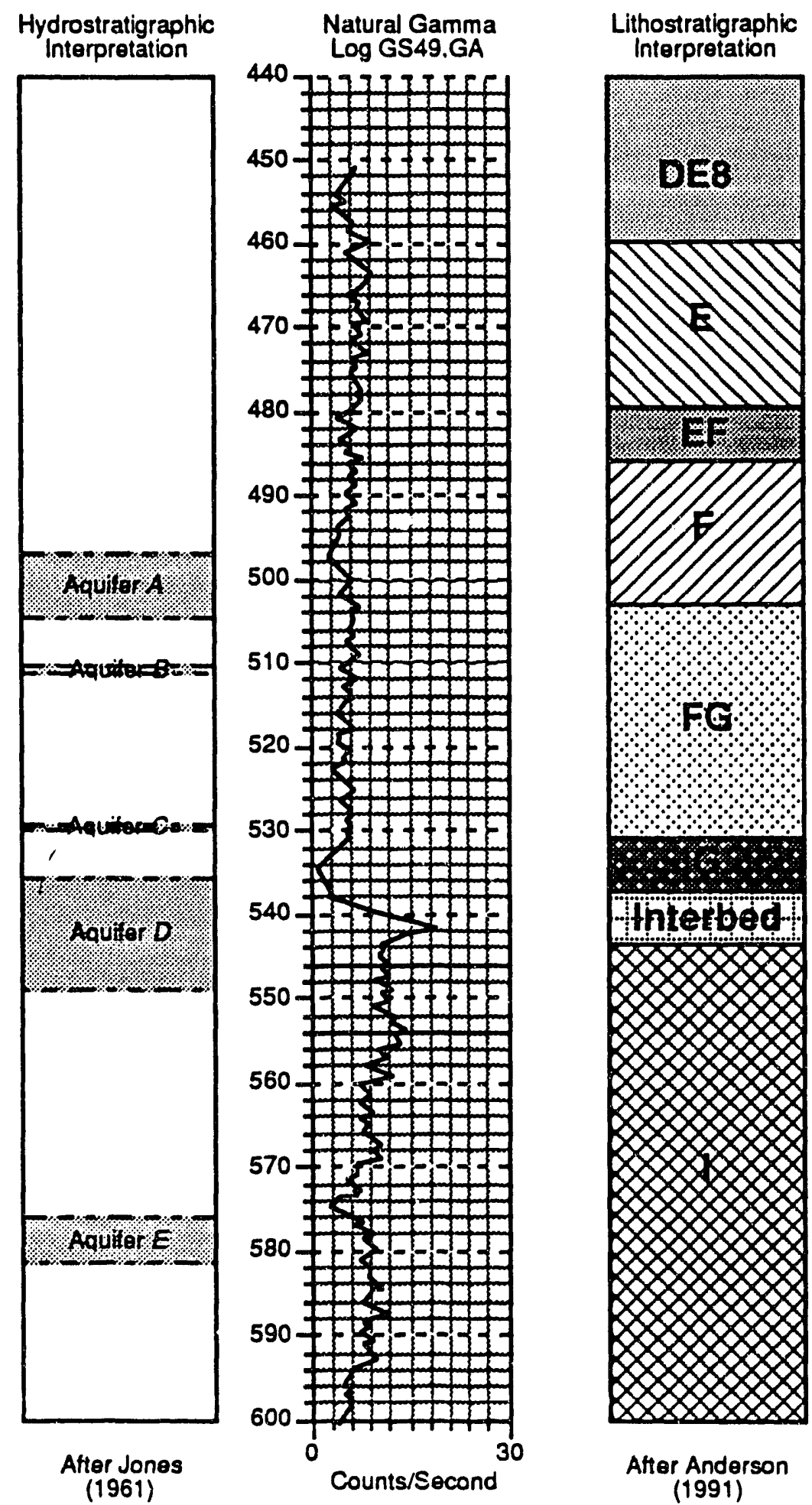

Figure A1-16. Caliper and natural-gamma logs for Well 49 below the regional water table showing hydrostratigraphic units determined by Jones (1961). Lithostratigraphic units, as interpreted by Anderson (1991), are also shown. Reference elevation $=4913$ feet (MSL). 


\section{APPENDIX 2.}

\section{Tracejector logs and geologic interpretations}

for selected ICPP monitoring wells 
Monitoring Well 42
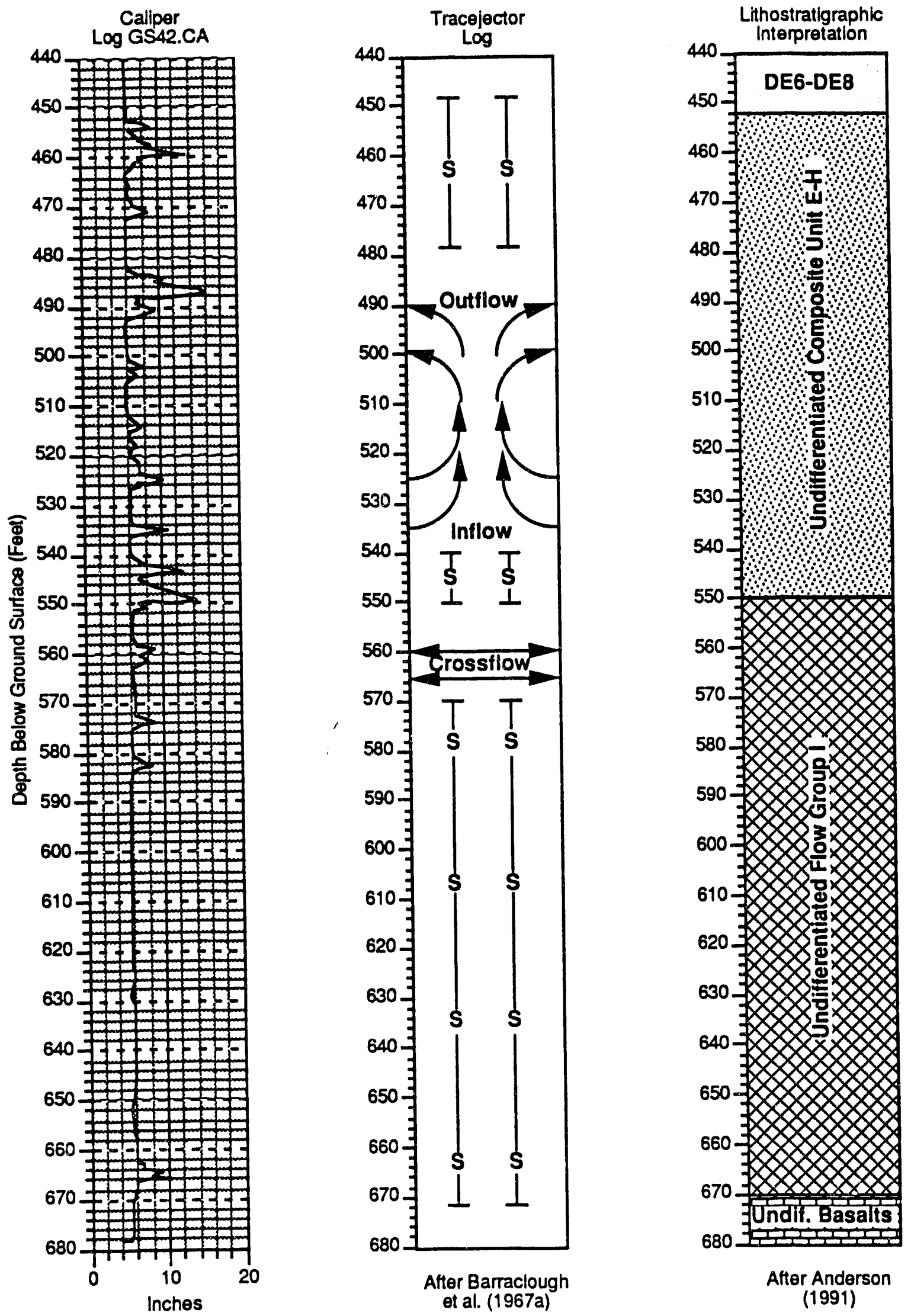

Figure A2-1. Tracejector test results (after Barraclough et al., 1967a), caliper log, and lithostratigraphic intervals (after Anderson, 1991) for monitoring well 42 at the ICPP. Reference elevation $=4917$ feet $(M S L)$. 


\section{Monitoring Well 43}
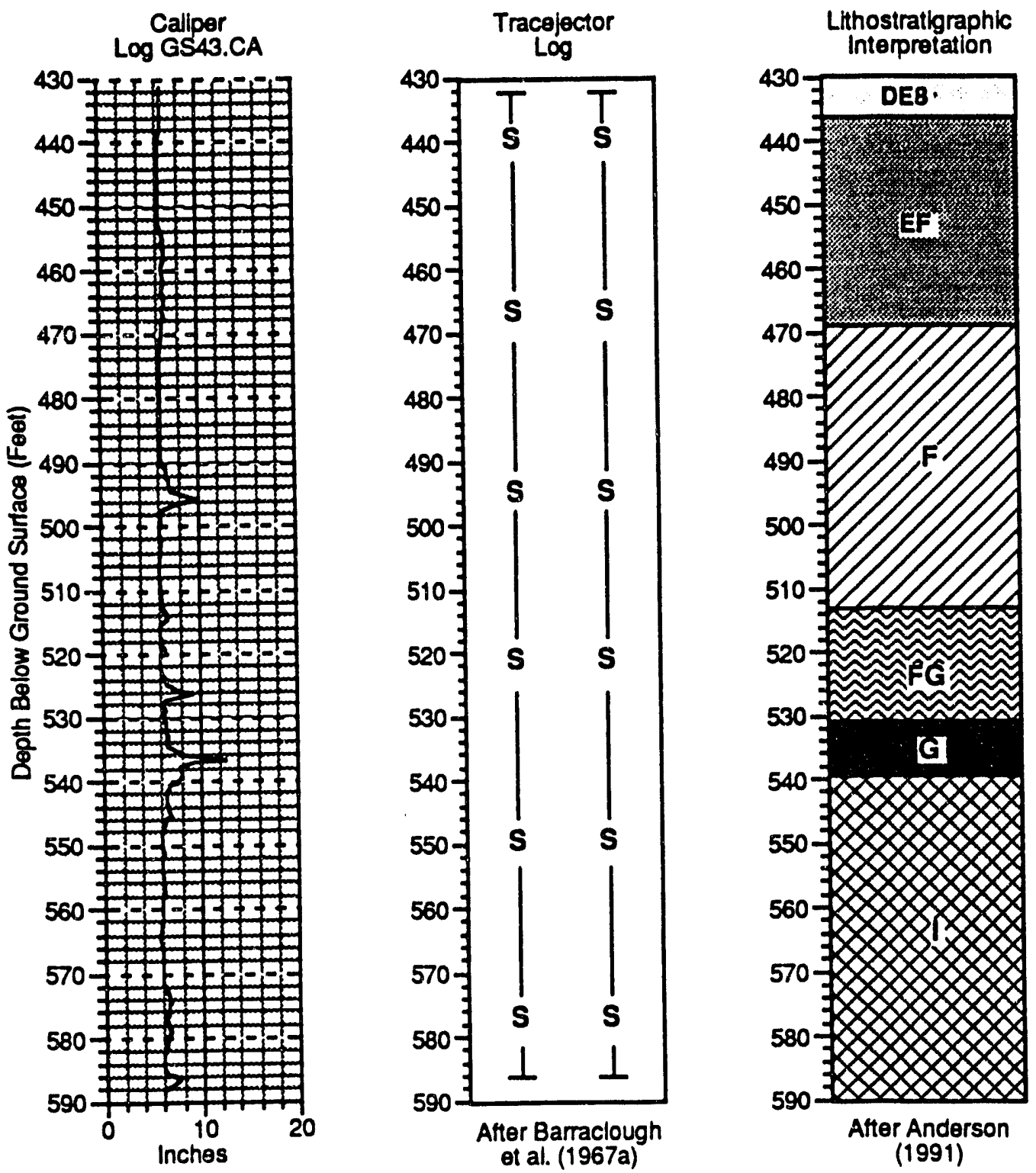

Figure A2-2. Tracejector test results (after Banaclough et al., 1967a), caliper log, and lithostratigraphic intervals (after Anderson, 1991) for monitoring well 43 at the ICPP. Reference elevation $=4916$ feet $(M S L)$. 

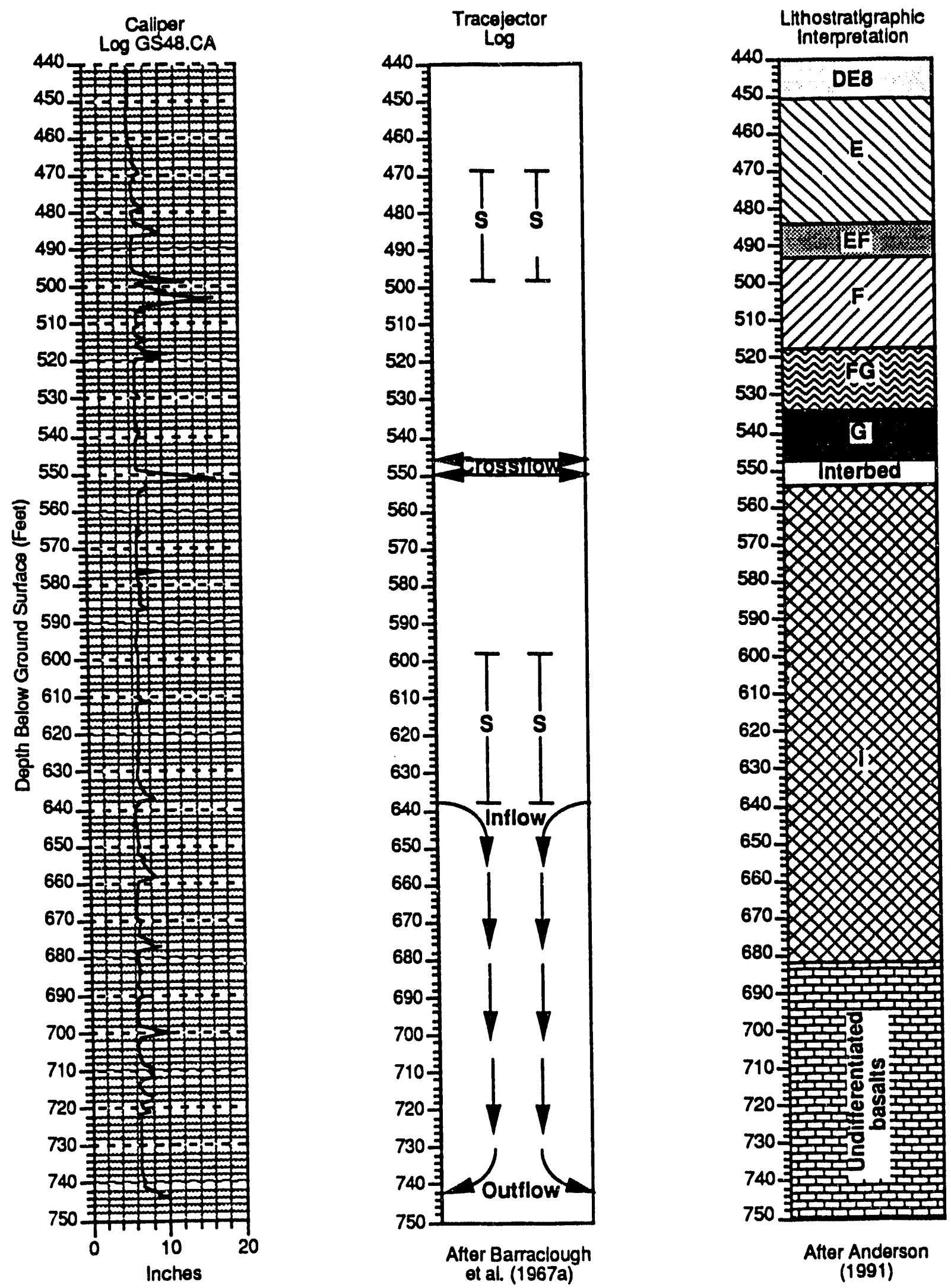

Figure A2-3. Tracejector test results (after Barraclough et al., 1967a), caliper log, and lithostratigraphic intervals (after Anderson, 1991) for monioring well 48 at the ICPP. Reterence elevation $=4917$ feet (MSL). 


\section{Monitoring Well 49}
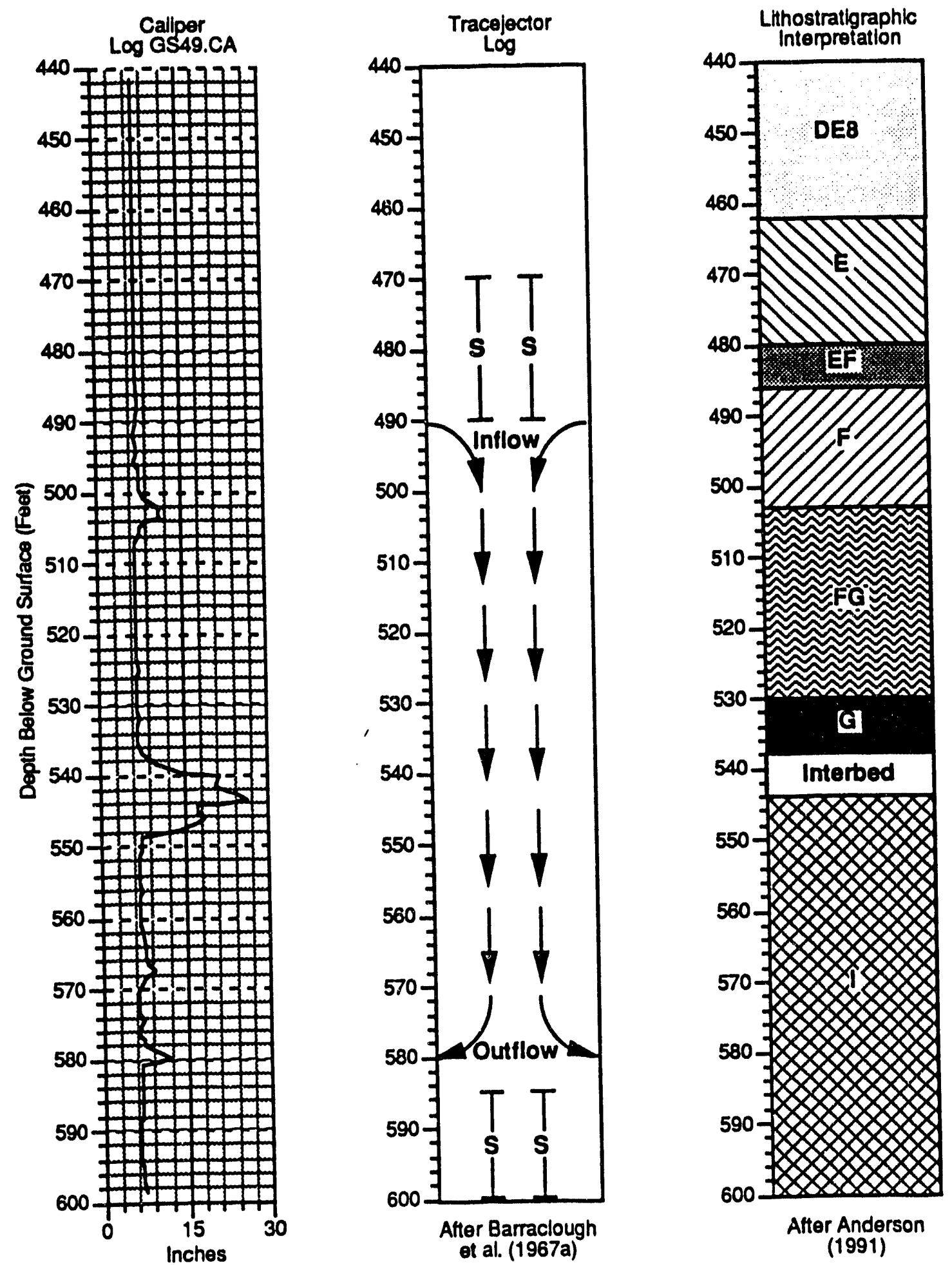

Figure A2-4. Tracejector test results (atter Barraclough et al., 1967a), caliper log, and lithostratigraphic intervals (atter Anderson, 1991) for monitoring well 49 at the ICPP. Referenco elevation $=4913$ feet $(M S L)$. 


\section{Monitoring Well 51}
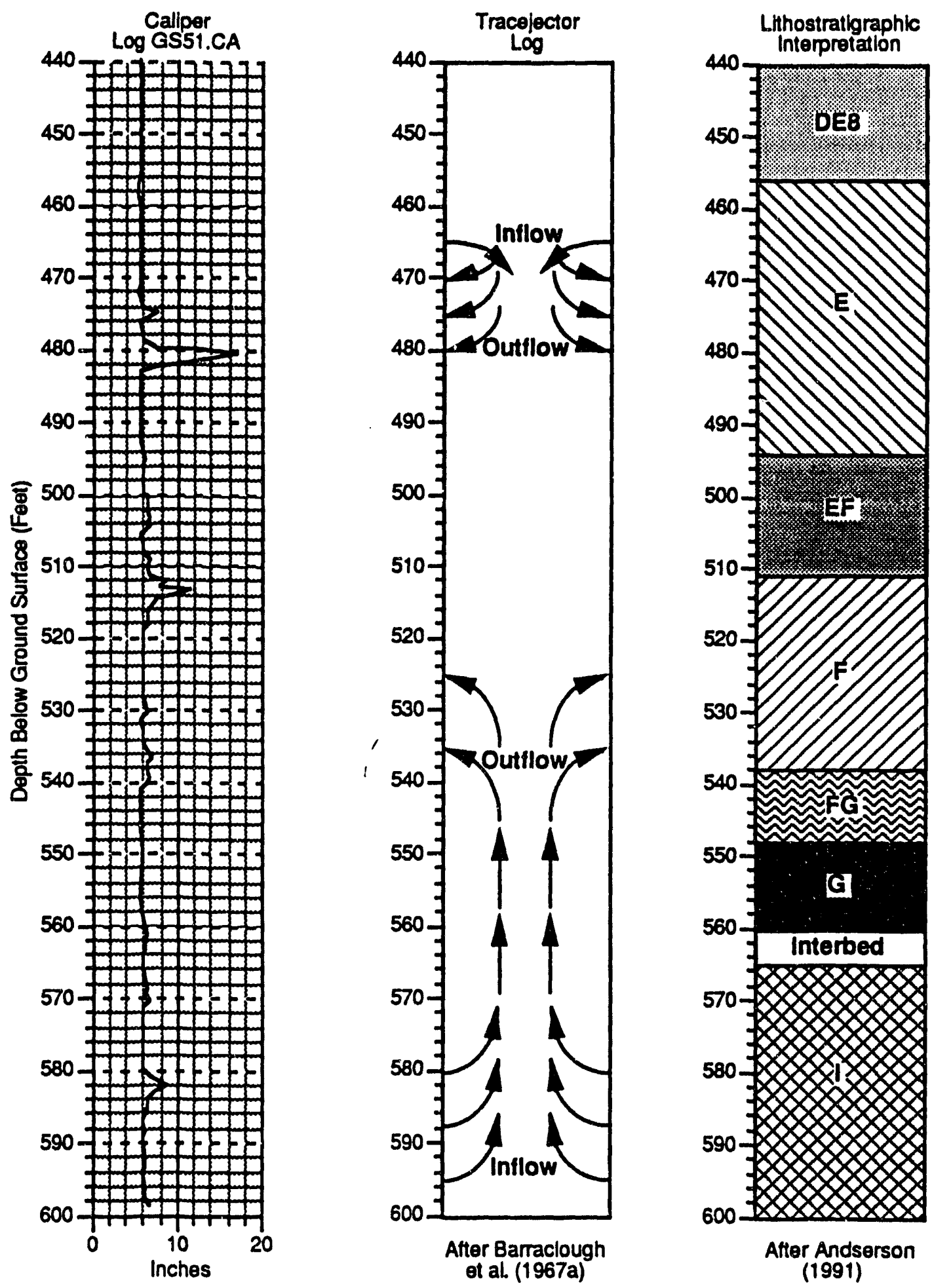

Figure A2-5. Tracejector test results (after Barraclough et al., 1967a), caliper log, and lithostratigraphic intervals (after Anderson, 1991) for monitoring well 51 at the ICPP Reference elevation $\mathbf{a} 4918$ feet $(\mathrm{MSL}$ ). 
Monitoring Well 52
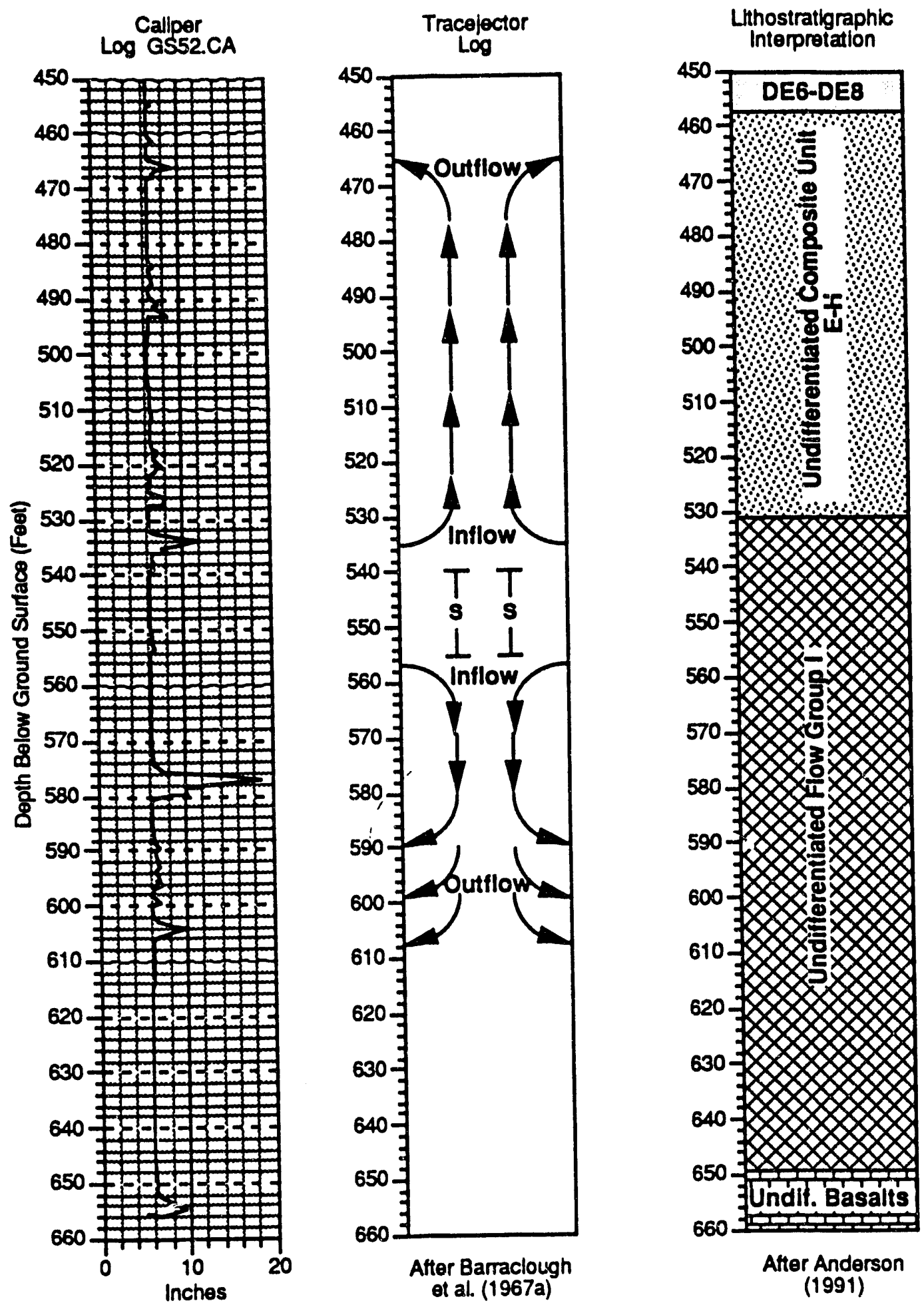

Figure A2-6. Tracejector test results (after Barraclough et al., 1967a), caliper log, and lithostratigraphic intervals (after Anderson, 1991) for monitoring well 52 at the ICPP. Reference elevation $=4910$ feet (MSL). 


\section{Monitoring Well 59}
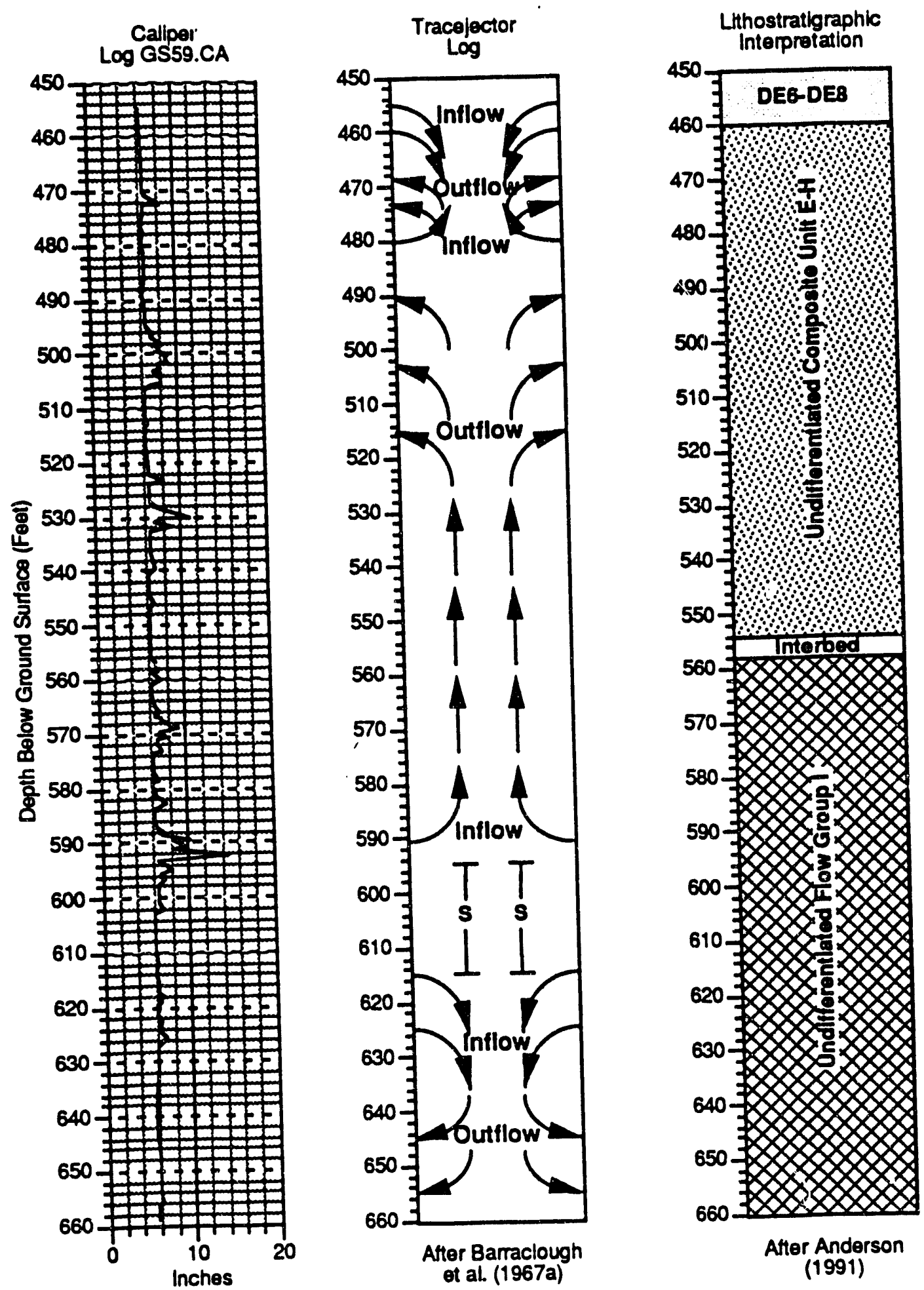

Figure A2-7. Tracejector test results (after Banacbugh et al., 1967a), caliper log, and lithostratigraphic intervals (after Anderson, 1991) for monitoring well 59 at the ICPP. Reference elevation $=4915$ feet (MSL). 

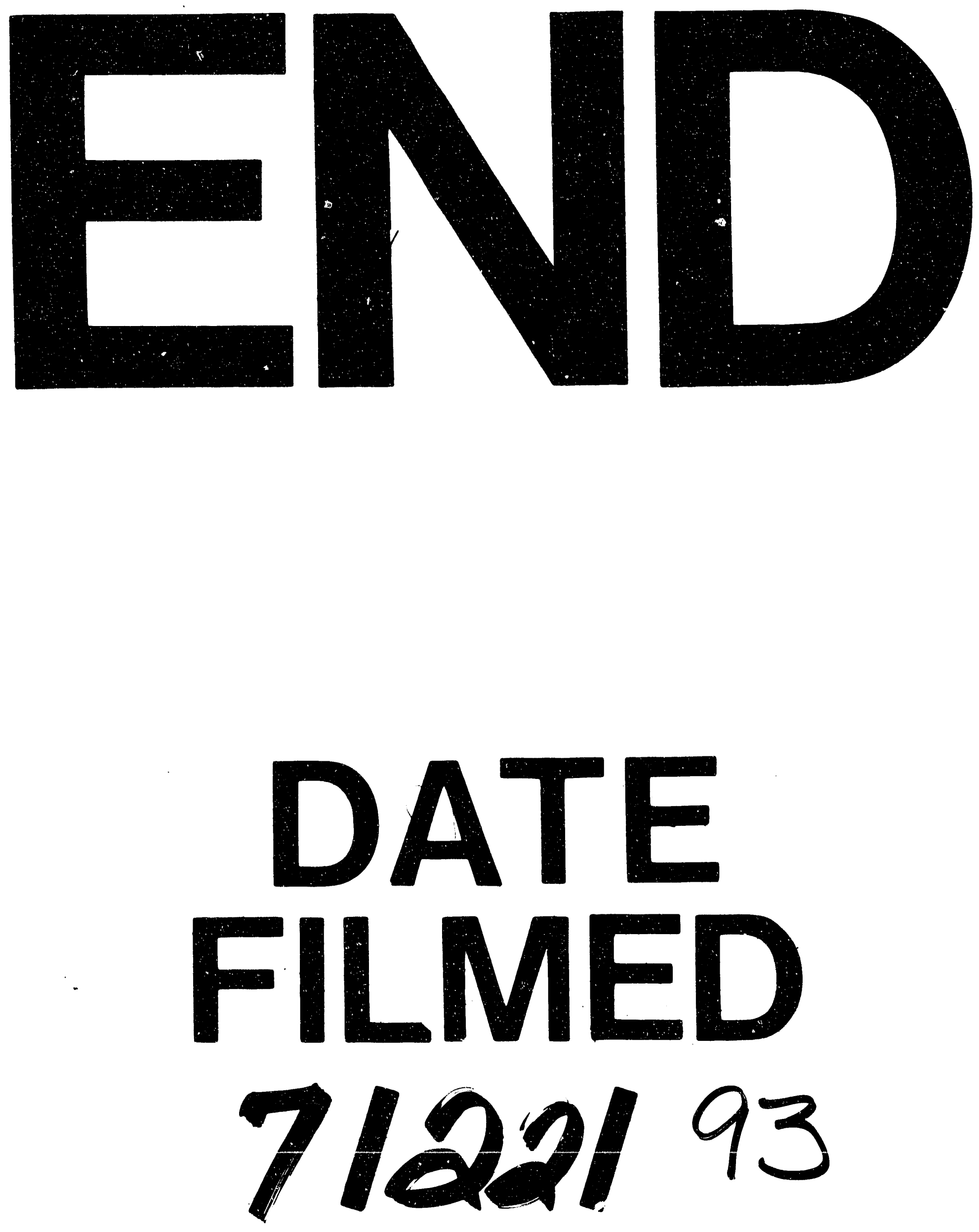


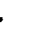

